MÁRCIA CUNHA TEIXEIRA

\title{
TRABALHO PENOSO: DA APLICAÇÃO DOS PRINCÍPIOS AMBIENTAIS PARA A REPARAÇÃO SOCIAL DOS DANOS
}

TESE DE DOUTORADO EM DIREITO

ORIENTADOR:

PROFESSOR ASSOCIADO OTAVIO PINTO E SILVA

FACULDADE DE DIREITO DA UNIVERSIDADE DE SÃO PAULO SÃO PAULO - 2013 


\section{TRABALHO PENOSO: DA APLICAÇÃO DOS PRINCÍPIOS AMBIENTAIS PARA A REPARAÇÃO SOCIAL DOS DANOS}

Tese apresentada ao Departamento de Direito do Trabalho e Seguridade Social da Faculdade de Direito da Universidade de São Paulo, sob a orientação do Professor Associado Otavio Pinto E SiLva, como requisito para obtenção do título de doutor. 
Banca Examinadora 
Em memória, ao meu pai, JosÉ TEIXEIRA, que me ensinou na prática o verdadeiro significado do princípio da dignidade da pessoa humana.

À minha mãe, MARÍLIA, pelo seu amor e dedicação e pelo gosto e respeito à língua pátria, que procurou me transmitir. Ao Nelson e LigiA, meu amor e gratidão perenes. 


\section{AGRADECIMENTOS}

Ao Professor e orientador Otavio Pinto e Silva, pelo constante incentivo no meu caminho na vida acadêmica; pelas orientações sempre atentas, precisas e gentis.

Aos Professores Antonio Rodrigues de Freitas Junior e Rodolfo Andrade de Gouveia Vilela, pelas preciosas observações efetuadas na banca de qualificação e pelos subsídios fornecidos que nortearam o amadurecimento das ideias desenvolvidas.

Aos Professores Homero Batista Mateus da Silva e Guilherme Guimarães Feliciano, que propiciaram o aprofundamento dos conhecimentos acerca do tema, em disciplina oferecida no curso de pós-graduação desta Faculdade.

À médica do trabalho e pesquisadora da Fundacentro, Maria Maeno, pela incansável defesa da saúde dos trabalhadores, pelos subsídios disponibilizados e pelos esclarecimentos técnicos, indispensáveis para o desenvolvimento deste trabalho.

À Cristiane Queiroz Barbeiro Lima, tecnologista do Serviço de Ergonomia da Fundacentro, pelos ensinamentos preciosos.

Ao advogado Antônio José de Arruda Rebouças, especialista em Previdência Social e defensor dos trabalhadores, pela inspiração quanto ao tema e auxílio inestimável.

À amiga de Maria Isabel Cueva Moraes, pela solidariedade e pela ajuda sempre presentes.

À Marta Casadei Momezzo, pelos conhecimentos transmitidos na trajetória profissional.

Ao amigo e batalhador pela saúde dos trabalhadores, Gilberto Salviano da Silva, pelo auxílio e pelo exemplo, pela persistência na defesa da classe trabalhadora.

À Karine Marielly Rocha da Cunha, pelo auxílio no trato com a língua italiana.

Ao sobrinho e amigo, Arthur Gomes Cardoso Teixeira, pela generosidade de sempre e pela ajuda no texto em inglês. 
$\mathrm{O}$ veio Guillaume era muito fino, tinha apenas cinquenta centímetros de espessura, de modo que os britadores precisavam trabalhar agachados entre o teto e o muro, arrastando-se com os joelhos e os cotovelos. Para quebrar a hulha, tinham que ficar deitados de lado, com o pescoço torto, batendo de viés com a picareta.

Embaixo ficava Zacharie; no meio, intercalados, Levaque e Chaval, e, no alto, Maheu. Eles cortavam o xisto e abriam entalhes verticais para retirar o bloco de carvão. Como aquela hulha era gordurosa, o bloco se quebrava e rolava em pedaços sobre os britadores.

Quem mais sofria era Maheu. No alto, a temperatura atingia trinta e cinco graus, o ar não circulava. Para poder ver, ele prendia o lampião num prego perto da cabeça, o que aumentava terrivelmente o calor. Mas era a umidade que aumentava o seu suplício. A rocha porejava água, gotas grossas batiam em seu rosto continuamente. Em quinze minutos, ele estava encharcado de água e suor.

[...] O vagonete de Éthienne acabava de descarrilar numa passagem mais difícil. Ele não conseguia rodar direito naqueles trilhos que se afundavam no solo úmido e xingava, enraivecia-se, lutava furiosamente com as rodas que não conseguia colocar no lugar, apesar dos esforços.

- Espere - disse a moça. Se você fica bravo, não vai conseguir rodar o vagonete.

Habilmente, se pôs de costas embaixo do carro, ficando com o peito e a cabeça de fora, e com um impulso das costas levantou o vagonete e o colocou nos trilhos: ele pesava setecentos quilos. Surpreso e envergonhado, Étienne se desculpou. [...]

(ZOLA, Émile. Germinal. São Paulo: Companhia das Letras, 2000.) 


\section{SUMÁRIO}

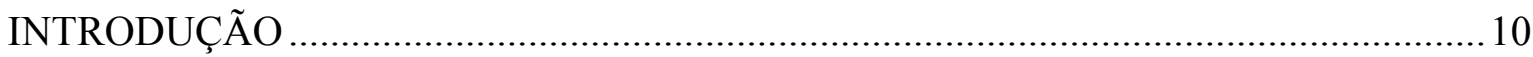

1. O tema a ser desenvolvido e suas limitações........................................ 10

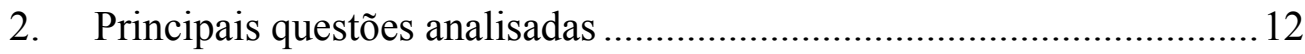

3. A contribuição original à ciência jurídica brasileira ...............................14

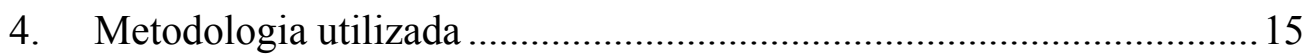

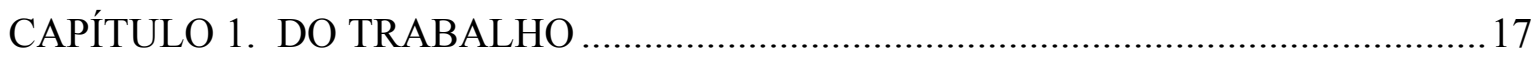

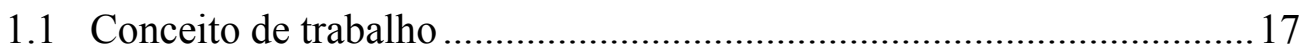

1.1.1 Evolução histórica: da escravidão ao trabalho remunerado ..........35

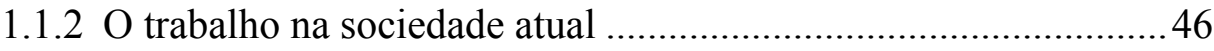

1.1.2.1 O trabalhador e o processo de organização do trabalho ...54

1.1.2.2 A globalização da economia e a precarização das rela-

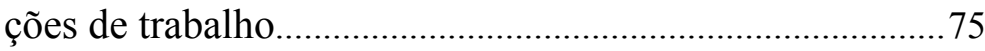

1.1.2.3. Danos físicos e transtornos psíquicos decorrentes do

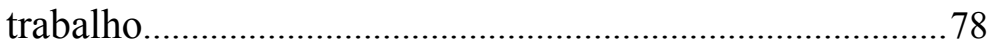

1.1.2.4 Custo social e custo previdenciário .....................................86

\section{CAPÍTULO 2. O TRABALHO E OS DIREITOS FUNDAMENTAIS. DO DIREITO} AO MEIO AMBIENTE DO TRABALHO EQUILIBRADO …..................90

2.1 Princípios e direitos fundamentais do trabalho nos planos internacional e nacional

2.2 Princípio da dignidade da pessoa humana, a ordem econômica e o valor social do trabalho

2.3 Princípios ambientais na esfera internacional e à luz da Constituição Federal. Do direito a uma vida saudável

2.3.1 Do meio ambiente do trabalho sadio e equilibrado como direito fundamental

2.3.2 Princípios da prevenção ou da atuação preventiva e da precaução

2.3.3 Princípio da participação

2.3.4 Princípios da responsabilização e do poluidor-pagador.

2.3.5 Arcabouço normativo estatal de proteção ao direito à saúde no trabalho

2.3.5.1 Medidas preventivas e protetivas da saúde do trabalhador. 
2.4 O papel dos poderes públicos. Da fiscalização do meio ambiente do trabalho

2.5 O papel da sociedade civil na proteção da saúde do trabalhador 131

2.5.1 Das entidades sindicais

2.5.2 Do empregador..

2.5.3 Da Comissão Interna de Prevenção de Acidentes - Cipa

2.5.4 Serviços Especializados em Engenharia de Segurança e em Medicina do Trabalho - SESMT

2.5.5 Programa de Controle Médico de Saúde Ocupacional PCMSO

2.5.6 Programa de Prevenção de Riscos Ambientais - PPRA

2.6 A concepção de eliminação dos riscos nos demais países - exemplos

da Europa e dos Estados Unidos da América....

2.7 Direito à saúde - conceito de preservação de acordo com a Organização Mundial da Saúde - OMS

2.7.1 A saúde do trabalhador como direito humano

3.1 Conceito

3.1.1 Natureza da atividade e seu contexto de execução

3.1.1.1 Organização do trabalho: meios materiais, aspectos ambientais, forma de produção e remuneração

3.1.1.2 Distinção entre insalubridade, periculosidade e penosidade.

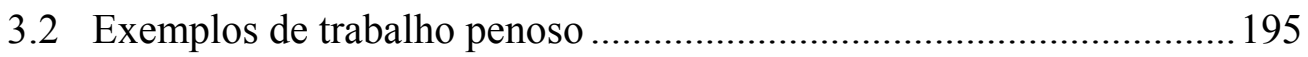

3.2.1 Corte de cana-de-açúcar e a morte por exaustão......................... 195

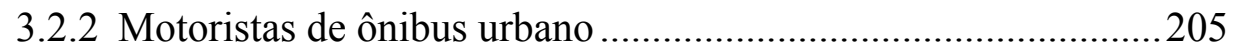

3.2.3 Turno ininterrupto de revezamento ..........................................208

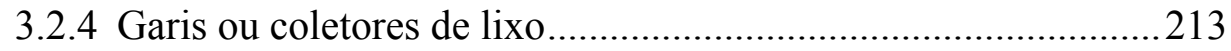

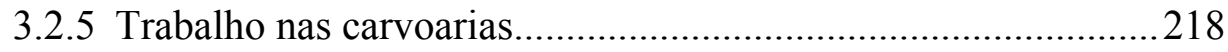

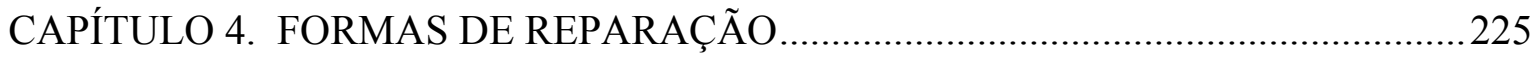

4.1 Perspectivas de reparação dos danos ..................................................225

4.2 Atuação do Ministério Público do Trabalho.........................................236

4.3 Responsabilidade do empregador .................................................. 241

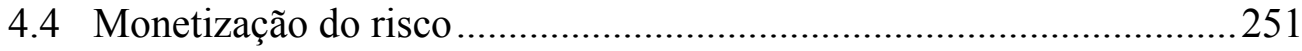

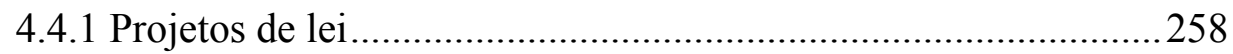


4.4.2 Exemplos de categorias que recebem o adicional de penosidade

4.5 A reparação dos danos pela Previdência Social. Avanços e retrocessos da legislação acidentária no Brasil

4.5.1 Aposentadoria especial

4.5.2 Grau de Incidência de Incapacidade Laborativa - Riscos Ambientais do Trabalho - GIIL RAT .......................................2282

4.5.3 Nexo Técnico Epidemiológico - NTEP....................................2283

4.5.4 Fator Acidentário de Prevenção - FAP .....................................28

4.6 A reparação dos danos ao trabalhador e o ressarcimento do custo social

CONCLUSÕES . 300

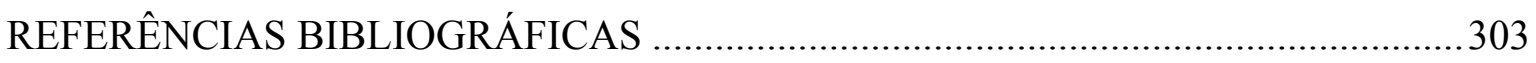

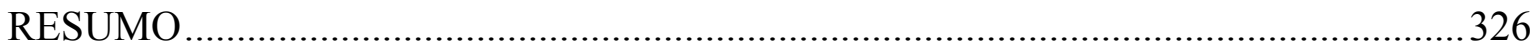

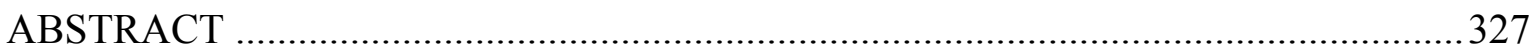

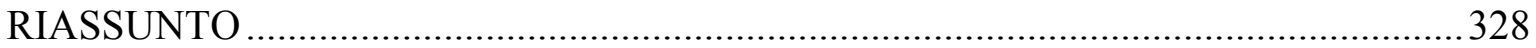




\section{INTRODUÇÃO}

\section{O tema a ser desenvolvido e suas limitações}

Trata este estudo do trabalho penoso; procura conceituá-lo, com foco nas atividades que, por sua natureza, condições e métodos de trabalho, exponham os trabalhadores à situação-limite de desgaste e sofrimento físico e mental, com consequências nefastas à sua saúde física e psíquica. Objetiva este estudo efetuar o debate no meio acadêmico, acerca da devida responsabilização dos causadores dos danos, de forma a propiciar o ressarcimento dos custos sociais deles decorrentes, assumidos pela Previdência Social e, portanto, por toda a sociedade, visando à punição dos responsáveis e à finalidade pedagógica, com objetivo principal e final da obtenção de um meio ambiente de trabalho adequado e sadio.

Para tanto, procurou-se no Capítulo 1 conceituar "trabalho" a partir de sua etimologia, passando pela influência religiosa, evolução histórica, do trabalho escravo ao remunerado, até chegar à realidade dos dias atuais; concepções filosóficas e econômicas que o amalgamaram foram examinadas. Efetuou-se a análise do trabalho na sociedade atual, com o exame do papel do trabalhador no processo de organização do trabalho; tratou-se da reestruturação produtiva do capital, das mudanças no mundo do trabalho; a globalização da economia, o incremento das novas tecnologias e as transformações que atingem hoje em dia a realidade do trabalho. As metamorfoses havidas no processo de produção do capital e suas repercussões no processo de trabalho, com a precarização das relações de trabalho e o aumento dos níveis de exploração foram enfocadas. Como consequência, foram estudados os danos físicos e os transtornos mentais, com nexo causal com o trabalho. Desse modo, não somente o ambiente físico foi estudado, bem como os aspectos relacionais do trabalho e suas consequências deletérias no ambiente laboral. Em face da ocorrência dos danos, enfocaram-se o custo social e os impactos para a Previdência Social.

No Capítulo 2, cuidou-se do trabalho e dos direitos fundamentais, no âmbito internacional e no plano interno. Tratou-se da concepção preventiva dos riscos; houve breve explanação sobre a concepção de habitat laboral saudável, de acordo com a 
Organização Internacional do Trabalho (OIT), para em seguida passar à análise da prevenção no âmbito do direito pátrio. Nesse prisma, buscou-se a dignificação do trabalho, e sua realização em um meio ambiente do trabalho equilibrado, de forma a assegurar a saúde, física e mental do trabalhador. Foram analisados os princípios ambientais à luz da Constituição Federal, enfocados os princípios da prevenção e da precaução e suas respectivas distinções. A legislação trabalhista, incluindo a normatização infralegal; a legislação sanitária no tocante à saúde do trabalhador, bem como as normas do direito previdenciário foram estudadas. A atribuição do SUS na Constituição Federal, a Lei Orgânica da Saúde, bem como alguns códigos de saúde e códigos sanitários estaduais, com conteúdo específico sobre saúde do trabalhador foram examinados. Esse capítulo tratou também dos papéis das entidades sindicais e dos Poderes Públicos, a importância da fiscalização, bem como qual a contribuição a ser dada pela sociedade civil na proteção da saúde do trabalhador.

Destacou-se a figura do empregador, e sua responsabilidade quanto às medidas preventivas. Em seguida, foram detalhados os papéis de órgãos e setores responsáveis pela prevenção dos riscos e agravos à saúde do trabalhador, como as Comissões Internas de Prevenção de Acidentes (CIPAs); os Serviços Especializados em Engenharia de Segurança e em Medicina do Trabalho (SESMT), com exame de sua importância na preservação da saúde dos trabalhadores e do ambiente de trabalho equilibrado. A concepção de eliminação dos riscos nos demais países foi verificada, com análise do direito comparado. Salientou-se a saúde do trabalhador como direito fundamental, aprofundando-se o conceito atual de direito à saúde, de acordo com a Organização Mundial da Saúde (OMS).

A conceituação de trabalho penoso foi efetuada no Capítulo 3. Para tanto, foram analisados a natureza da atividade e o contexto de execução, com estudo da forma de organização do trabalho, os meios materiais disponíveis para o desenvolvimento das tarefas, os aspectos ambientais, a forma de produção e remuneração. Efetuou-se a distinção entre insalubridade e periculosidade para reforçar as características precípuas da penosidade. Alguns exemplos de trabalho penoso foram elencados e estudadas as atividades: corte de cana-de-açúcar; motoristas de ônibus urbano; trabalho realizado em turno ininterrupto de revezamento; coleta de lixo e o trabalho nas carvoarias. 
O Capítulo 4 tratou das formas de reparação dos danos. Da fonte do Direito Ambiental foi trazido o princípio do poluidor-pagador para fundamentar a reparação em face das sequelas propiciadas pelo trabalho penoso. Tratou-se da responsabilidade do empregador não somente em decorrência do contrato de trabalho e da responsabilidade civil, bem como por força dos custos sociais provocados pelo trabalho em condições penosas e da exploração da atividade econômica em desrespeito ao limite do risco permitido. Por isso, salientou-se que a Previdência Social concede os benefícios devidos em decorrência dos sinistros, e o contribuinte é que acaba arcando com tais custos. $\mathrm{O}$ estudo propôs que o causador dos danos deve ser o responsável principal pelas consequências de sua ação (ou omissão), na chamada "internalização das externalidades" dos custos sociais. O capítulo afastou a vertente da monetização, procurando aprofundar o debate em torno da forma de reparação dos danos, por meio de ressarcimento à Previdência Social, com análise da legislação previdenciária; propôs-se o retorno da concessão da aposentadoria especial para quem exerce trabalho penoso, além da revogação da legislação que criou o Fator Acidentário de Prevenção (FAT), pela inconsistência, falta de confiabilidade dos dados e inexistência de fiscalização.

Por fim, apontou-se o caminho para a reparação do custo social, por meio da imputação objetiva e ressarcimento da Previdência Social, com previsão legal, com o fito de punir o poluidor-pagador, atingir a finalidade pedagógica, visando à consecução de um ambiente de trabalho adequado e sadio.

\section{Principais questões analisadas}

De início, efetuou-se o estudo do trabalho e as condições em que é exercido, isto é, o trabalho que, pela natureza das funções ou em razão de fatores ambientais, provoca uma sobrecarga física e ou psíquica para o trabalhador, bem como foram abordadas suas consequências, tanto para a vítima quanto para a família e a sociedade em geral.

Para tanto, foram adotados como norte os critérios estabelecidos em outras disciplinas, como a medicina do trabalho, a ergonomia, a psicopatologia do trabalho, a engenharia de segurança no trabalho, e analisou-se o processo de organização do trabalho, esmiuçado em disciplinas como administração de empresas e sociologia do trabalho. 
Foram salientados, considerada a organização do trabalho, a tarefa prescrita, os meios materiais e equipamentos, os aspectos ambientais e temporais da realização da tarefa, e demais fatores, como condições agressivas de trabalho, com exposição a agentes insalubres e ou perigosos, causas multifatoriais apontam para situação-limite que caracteriza o trabalho penoso, sem possibilidade de controle e amenização, considerado o atual estágio das tecnologias e recursos disponíveis.

Para essa compreensão, foi imprescindível o exame de normas e princípios de direito interno e internacional do trabalho, sobre o direito fundamental ao meio ambiente do trabalho sadio, com foco nos princípios da prevenção e da precaução, e na consecução dos direitos fundamentais previstos na Constituição Federal, como o direito à vida, à integridade física e mental, bem como ao direito à vida digna, à luz do princípio da dignidade da pessoa humana. Inarredável a análise dos preceitos previstos constitucionalmente, voltados à redução dos riscos inerentes ao trabalho; a normatização infraconstitucional relativa à segurança e medicina do trabalho, prevista na Consolidação das Leis do Trabalho (CLT) e demais normas pertinentes; bem como as previsões regulamentares estabelecidas pelo Ministério do Trabalho e Emprego sobre segurança e medicina do trabalho, visando à proposição final, destinada à reparação dos danos ocorridos por força do descumprimento da normatização citada. Princípios do direito previdenciário são de exame obrigatório, como o de caráter compensatório, que norteia a concessão de benefícios pela Previdência Social, resultantes dos agravos à saúde dos trabalhadores pelas atividades laborativas nocivas à saúde; bem como o contributivo destinado ao financiamento da Seguridade Social.

A legislação previdenciária que institui o Fator Acidentário de Prevenção (FAP), Lei 10.666 , de 8 de maio de 2003, foi examinada, assim como o diploma legal que introduziu no ordenamento jurídico brasileiro o conceito do Nexo Técnico Epidemiológico (NTEP), por meio da Lei 11.430, de 26 de dezembro de 2006, estabelecendo a presunção da natureza ocupacional do agravo, sempre que verificada a correlação entre a entidade mórbida incapacitante e a atividade econômica desenvolvida pela empresa, com a inversão do ônus da prova. O cotejo entre o FAP e o NTEP foi efetuado e os existentes no sítio da Previdência Social foram examinados para demonstrar a inconsistência do FAP. 
Tais questões serviram de baliza para a pesquisa, até a conclusão de qual é a alternativa mais eficaz para reparação dos danos decorrentes do trabalho penoso, afastada a via da monetização. Nesse sentido, foram examinados princípios ambientais, como o do poluidor-pagador, e a imputação objetiva, a responsabilização objetiva labor ambiental, para ressarcimento social dos danos, por meio de nexo normativo.

\section{A contribuição original à ciência jurídica brasileira}

O presente trabalho objetiva contribuir com a ciência jurídica brasileira com o debate e reflexão acerca do conceito e caracterização do trabalho penoso, do estudo dos danos decorrentes dessa forma de trabalho, com foco na reparação dos danos e do custo social, com as seguintes vertentes:

a) a da prevenção dos riscos, galgada à condição de direito fundamental, do direito de proteção da vida e da integridade física e mental, bem como do direito à vida digna, à luz do princípio da dignidade da pessoa humana;

b) a da reparação dos danos, não exclusivamente focada na indenização ao trabalhador, na forma de monetização do risco e remuneração de mais um adicional, e sim na reparação do custo social, no ressarcimento à sociedade, por meio da Previdência Social, que arca com a concessão dos benefícios ao segurado e também aos seus beneficiários.

O trabalho penoso, que provoca sobrecarga física e psíquica para o trabalhador, e que redunda no mais das vezes em trágicas consequências, situa-se em uma zona de confluência entre o trabalho exercido em condições de insalubridade e de periculosidade, tendo, todavia, características próprias. Como não está regulamentado, o dispêndio que gera não onera na devida proporção o empregador, que exigiu e permitiu que o labor fosse executado nessas condições.

A originalidade da contribuição à ciência jurídica brasileira corresponde ao estudo sobre a forma mais eficaz de prevenção dos riscos e de reparação dos danos, ao trabalhador e à sociedade, em razão do custo social propiciado pelo trabalho penoso. 
Nessa esteira, o estudo afasta a vertente da monetização do risco, tece críticas e expõe a inconsistência e não confiabilidade do Fator Acidentário de Prevenção (FAP), propõe a revogação da legislação que o instituiu, com edição de outra norma, efetivamente voltada à prevenção e à proteção da saúde e da integridade física e mental dos trabalhadores, pois a que se encontra atualmente em vigor transformou-se em um instrumento de premiação do capital, sem propiciar qualquer melhoria comprovada nas condições de trabalho, como comprovam os índices de doenças e acidentes do trabalho do FAP, em cotejo com os números do Nexo Técnico Epidemiológico (NTEP).

Dentre outras medidas voltadas à fiscalização, o estudo propõe a instituição do Cadastro Nacional Unificado das doenças e acidentes do trabalho, de modo a possibilitar a publicidade de dados confiáveis e por conseguinte maior controle social.

E à luz de princípios ambientais, como o do poluidor-pagador, e da imputação objetiva, quando se verificar por perícia administrativa que em determinada atividade houve uma conduta criadora do risco proibido, que incrementou o risco permitido, oriundo da atividade penosa, quando se constatar que houve exploração desmesurada do trabalho humano, como são os casos de morte por exaustão, a Previdência Social deverá ser ressarcida, conforme previsão que deverá constar em lei, mediante cobrança de dívida, sem provocação judicial, vale dizer, sem necessidade de ajuizamento de ação regressiva para ressarcimento do dano.

As ideias ora propostas têm o objetivo de contribuir para que o princípio da dignidade da pessoa humana seja efetivamente aplicado no dia a dia do trabalhador brasileiro, e não somente um preceito constitucionalmente previsto.

\section{Metodologia utilizada}

A pesquisa desenvolveu-se por meio do exame de teses defendidas em obras jurídicas, com verificação de jurisprudência a respeito da matéria, bem como da análise de publicações científicas de outras áreas do conhecimento, como medicina do trabalho, em especial ergonomia, psicologia do trabalho, engenharia de segurança, economia e sociologia do trabalho, pois o presente estudo demanda o cotejo multidisciplinar entre ciências que têm ligação com a matéria. 
A bibliografia elenca obras citadas ou consultadas, do direito pátrio, bem como publicações e artigos das diversas disciplinas relacionadas ao tema, além de doutrina estrangeira. A disciplina central é o Direito do Trabalho, mas há uma inter-relação com o Direito Previdenciário e Acidentário, o Direito Ambiental, além do Direito Econômico, que o presente estudo realiza, ainda que de forma tangencial.

Além da pesquisa bibliográfica, realizou-se pesquisa de divulgações da mídia impressa, por meio de matérias jornalísticas publicadas em jornais e revistas, bem como busca de dados e informações pela internet, para melhor detecção da realidade brasileira.

Pesquisas foram realizadas a partir de entrevistas com pesquisadores da área de segurança e medicina do trabalho.

Este trabalho segue as normas recomendadas pela Associação Brasileira de Normas Técnicas (ABNT), pela Resolução FD/PÓS n. 01, de 10 de setembro de 2002, da Comissão de Pós-Graduação da Faculdade de Direito da Universidade de São Paulo. 


\section{CAPÍTULO 1 \\ DO TRABALHO}

\subsection{Conceito de trabalho}

A construção do conceito de trabalho tem sido objeto de investigação de diversas correntes de pensamento da ciência clássica, moderna e contemporânea. Na história do pensamento ocidental o conceito de trabalho evoluiu por uma linha não coerente; ora desprezado, ora enaltecido no plano moral, o trabalho passou por transformações conceituais, da Antiguidade ao mundo pós-industrial e pode-se dizer que essa trajetória está longe do fim.

O trabalho remonta às origens do homem. De acordo com a concepção bíblica, como castigo pela desobediência humana ao provar do fruto do conhecimento do bem e do mal, Deus expulsa o homem do Jardim do Éden, determinando que deva cultivar o solo em busca do seu sustento: "Do suor do teu rosto comerás o teu pão, até que tornes à terra [...]". ${ }^{1}$ Predomina a ideia de que o trabalho, como consta do texto bíblico, é um castigo, uma pena que deve ser cumprida, e, portanto, seria algo desagradável.

No entanto, não foi sempre assim, como observa Sérgio Feldman. Pondera este que as fontes bíblicas são vastas e complexas; há inúmeras maneiras de se abordar o texto bíblico. Há formas judaicas e cristãs; há óticas fundamentalistas e há óticas que tentam adaptar o texto à realidade dos tempos, para utilizá-lo como referência para propagação de valores éticos e morais. Esse autor diz que há que se ampliar o olhar para o texto como um conjunto; no capítulo anterior à queda, descrita no capítulo terceiro, há a idealização do trabalho no Jardim de Éden.

Ressalta Feldman que o local do Éden é descrito como aprazível e fértil, sendo repleto de árvores esplendorosas que Adão deveria cultivar e das quais poderia se utilizar, restrição feita às duas árvores que lhe eram vetadas: a do conhecimento do bem e do mal e a da vida.

\footnotetext{
1 Gênesis, capítulo 3, versículo 19.
} 
Salienta esse autor que Adão trabalhava; diz que seria errôneo interpretar o texto como se o Homem nada fizesse e estivesse alheio a funções e deveres: era o administrador e usuário do pomar do Jardim de Éden. Reporta-se ao texto bíblico: "E tomou o Eterno Deus o homem e colocou-o no Jardim de Éden, para o lavrar e cuidar". ${ }^{2}$ Assim, trabalhar é algo prezado, valorizado e "divinamente" criado, ${ }^{3}$ antes de o homem ser expulso do paraíso. Evidencia-se, afirma Feldman, no arcabouço mítico do texto bíblico, uma clara diferenciação entre as áreas desérticas e semidesérticas do Oriente Próximo, na qual habitavam os hebreus e outros povos semitas da periferia e as cobiçadas terras a margem dos rios caudalosos, citados nos versículos anteriores que fazem menção aos rios do Éden, tendo entre eles o Tigre e o Eufrates (Gênesis, 2:14).

O homem sempre trabalhou; em primeiro lugar, para obter alimentos; depois, passou a fabricar armas e instrumentos de defesa, de ossos ou de lascas de pedra, nos tempos primitivos. Jorge Souto Maior, mencionando Grellet, registra que o trabalho do homem primitivo, mesmo desordenado, na procura aleatória de alimento e na busca de defesa contra inúmeros inimigos, foi fonte para "uma série interminável de raciocínios, que constituíram a base de seu desenvolvimento mental". 4

Souto Maior ensina que a satisfação das necessidades humanas passa a exigir que os homens se unam par a concretização do trabalho. Diz que as pessoas que viviam às margens do Nilo, antes mesmo da formação do Egito, reconheceram a importância do trabalho em conjunto, pois "precisavam uns dos outros, para construir os canais de irrigação e conservar as represas em bom estado". 5

Nos combates entre tribos, os vencidos eram mortos; observou-se depois que era mais vantajoso aproveitar do trabalho dos prisioneiros, em vez de dizimá-los. Dá-se o início à venda e troca da mão de obra humana por aqueles que faziam grande número de prisioneiros e não podiam aproveitar de todos esses homens em seu serviço pessoal. Como

2 Gênesis, capítulo 2, versículo 15.

3 FELDMAN, Sergio Alberto. Trabalho e escravidão no Judaísmo bíblico. Arquivo Maaravi - Revista Digital de Estudos Judaicos da UFMG, v. 1, n. 2, mar. 2008. Disponível em: $<$ https://www.ufmg.br/nej/maaravi/artigosergiofeldman1-torah.html $>$.

4 SOUTO MAIOR, Jorge Luiz. Curso de direito do trabalho: teoria geral do direito do trabalho. São Paulo: LTr, 2011. v. 1, Parte I, p. 43.

5 Idem, ibidem, p. 44. 
destaca Segadas Vianna, aos escravos eram dados os serviços manuais exaustivos não só por essa causa, como, também, porque tal gênero de trabalho era considerado impróprio e até desonroso para os homens válidos e livres. ${ }^{6}$

A escravidão existe desde os tempos imemoriais, até a forma criminalmente tipificada nos dias de hoje, trabalho análogo à condição de escravo, na antiguidade predominou o trabalho escravo, emprestando ao labor uma conotação infamante; historicamente o trabalho está relacionado ao sofrimento, castigo e penosidade, sendo exíguo o trabalho prestado por homens livres.

Na Grécia antiga, como observa Domenico De Masi, os gregos encaravam o trabalho dependente com o maior desprezo, bem como qualquer outra atividade que implicasse fadiga física, ou ainda qualquer outra atividade executiva. ${ }^{7} \mathrm{Na}$ concepção aristotélica, o trabalho é incompatível com a vida livre, o ócio é enaltecido, e não se confunde com a preguiça. E é no ócio que o homem encontra a virtude, qualidade relacionada à prática. Para a Antiguidade Clássica, os cidadãos não deveriam ser artesãos, mercantes ou camponeses, pois não restaria tempo para as atividades política, filosófica e artística.

Jorge Souto Maior, reportando-se aos ensinamentos de Marilena Chauí, salienta que o desprezo pelo trabalho na Antiguidade pode ser constatado a partir de "sintomas significativos", dentre os quais o fato de não haver, na língua grega, uma palavra para significar trabalho; usa-se ergon, que significa obra; ou ponos, esforço penoso e doloroso. ${ }^{8}$

A palavra latina da qual deriva "trabalho" é tripalium, instrumento com três estacas utilizado para tortura. Originam-se do latim tardio tripaliu os vocábulos neolatinos travaglio, travail, trabajo e finalmente trabalho. ${ }^{9} \mathrm{E}$ a outra palavra latina empregada para designar trabalho é labor, que corresponde ao grego ponos; assim, indica pena, fadiga,

6 VIANNA, Segadas; SÜSSEKIND, Arnaldo; TEIXEIRA FILHO, João de Lima; MARANHÃO, Délio; TEIXEIRA, Lima. Instituições de direito do trabalho. São Paulo: LTr, 2000. p. 27.

7 DE MASI, Domenico. Desenvolvimento sem trabalho. São Paulo: Esfera, 1999. p. 13.

8 SOUTO MAIOR, Jorge Luiz. Curso de direito do trabalho: teoria geral do direito do trabalho. São Paulo: LTr, 2011. v. 1, Parte I, p. 30.

9 MARQUES, Christiani. A proteção ao trabalho penoso. São Paulo: LTr, 2007. p. 19. 
cansaço e dor. Os homens livres dispõem de otium - lazer - e os não livres estão no negotium, que a negação de ócio, trabalho. ${ }^{10}$

Sintetiza Felice Battaglia que para o mundo clássico grego e romano o trabalho está relegado às artes vis e é peso e fadiga, por isso condenado, indigno da essência humana, da liberdade.

Ressalva, no entanto, vozes destoantes, que exaltavam os valores do trabalho, como Hesíodo, que opõe a uma humanidade agitada pela luta outra humanidade, que se fundamenta na justiça e no trabalho. Diz esse autor que o poeta grego não se destaca do quadro que apresenta o trabalho como dura pena, como extenuante fadiga; o trabalho é necessário, porque Júpiter o impôs aos homens em consequência do pecado de Prometeu. Tal ideia retornará no mito judaico cristão do Paraíso terrestre, já mencionado. ${ }^{11}$

Prossegue Battaglia dizendo que, segundo Hesíodo, o trabalho tem sua racionalidade; para ser frutífero, deve ser feito a tempo, de acordo com uma certa técnica; o trabalho é disciplina, implica assiduidade, ordem, plenitude, de onde surgem os preceitos práticos.

Essa concepção é interpretada, sobretudo pelos sofistas, e Pródico é o verdadeiro teorizador do trabalho na sofística; e no seu apólogo diz que, se o homem segue as tendências racionais que constituem a virtude, o homem se aperfeiçoa e se eleva. E não há progresso em tal sentido que não implique estudo e fadiga, "Porque nada do que é bom e belo concederam os deuses aos homens sem esforço e sem estudo". ${ }^{12}$

Battaglia explica as duas teorias tão diversas e antinômicas sobre o trabalho, encontradas no mundo grego; por um lado, o trabalho é exaltado como essência do homem e, por outro, é repelido, como obra de escravos. Afirma que não são duas formulações

\footnotetext{
10 SOUTO MAIOR, Jorge Luiz. Curso de direito do trabalho: teoria geral do direito do trabalho. São Paulo: LTr, 2011. v. 1, Parte I, p. 30.

11 BATTAGLIA, Felice. Filosofia do trabalho. São Paulo: Saraiva, 1958. p. 31-32.

12 Idem, ibidem, p. 33-34.
} 
acidentais, e sim duas concepções da vida que têm origem diversa, pois nascem em ambientes diversos e personalizam duas classes de pessoas. ${ }^{13}$

É com a civilização hebraica que o trabalho adquire sentido, afirma Battaglia; enquanto a noção grega de trabalho é herança dos deserdados, fadiga e pena, sem nenhuma explicação, o hebraísmo oferece a explicação, dizendo que o trabalho é uma pena imposta aos homens pelo pecado original cometido por Adão e Eva no Paraíso terrestre. Trata-se de expiação, por meio do qual se resgata o bem que se havia perdido diante de Deus, a dignidade; assim, o trabalho é fator de dignificação.

Por isso, ressalta Battaglia, os hebreus não passavam indiferentes diante dos trabalhadores entregues às fainas do campo sem um aceno de saudação, sem uma benção. Acrescenta esse autor que o mito hebraico transpôs os limites da concepção antiga da vida, pois sobrepôs o trabalho como expiação de culpa, como penoso resgate humano e prenda da nova paz dos homens com Deus, dando-lhe um sentido construtivo ou reconstrutivo a todos os esforços que empregue o homem sobre a terra para readquirir a felicidade perdida. ${ }^{14}$

Battaglia traz a distinção entre o profetismo hebraico e o cristianismo, para se entender o reino; naquele, era inteiramente terreno e material; e o reino espiritual em Jesus se faz imanente, reino espiritual dos homens in hoc mundo. Sob este novo plano, o trabalho passa a adquirir sentido, pois o que se pretende deve começar a ser aqui, se o reino para ser em Deus deve começar a ser inter homines. ${ }^{15}$

Nos primeiros tempos do cristianismo, o trabalho continuou a ser visto como punição; contudo, funções positivas do trabalho começam a ter relevo; ele serve à saúde do corpo, pois no ócio ela se enfraquece e o espírito se inclina ao mal. Assim, resulta para o indivíduo o dever de trabalhar e para a comunidade o de dar trabalho. Felice Battaglia destaca o pensamento de São Paulo, o primeiro a exprimir a visão de que é melhor que o

\footnotetext{
13 BATTAGLIA, Felice. Filosofia do trabalho. São Paulo: Saraiva, 1958. p. 36-37.

${ }^{14}$ Idem, ibidem, p. 58-59.

15 Idem, p. 68.
} 
cristão trabalhe, pois assim não deve nada a ninguém; e, mesmo se não tiver bens, poderá enfrentar sereno a luta pela religião. ${ }^{16}$

De acordo com o pensamento de Santo Agostinho, o trabalho era um preceito religioso; trabalhar e rezar deveriam ser as atividades gloriosas de todos os cristãos. Ele considerava a agricultura a principal atividade humana, verdadeiro ato religioso. O labor era uma forma de impedir que o ócio conduzisse o homem aos vícios. ${ }^{17}$

Para o protestantismo de João Calvino, as habilidades do trabalho devem ser incentivadas, na medida em que são ofertas divinas. O trabalho não eleva, é simplesmente o cumprimento de uma predestinação. A teoria da predestinação afirma que um dos sinais de salvação é justamente a riqueza acumulada. Incerto seu destino, o fiel buscaria, incessantemente, o trabalho e o lucro.

Mais tarde, Max Weber procurou estabelecer um nexo entre o calvinismo e o que chamou de "espírito do capitalismo". Esse espírito seria uma atitude que valoriza o comportamento aquisitivo, a competitividade e a racionalidade. A ética medieval católica condena a acumulação de capitais e o empréstimo a juros. $\mathrm{O}$ calvinismo propõe o trabalho como forma de retirar o homem do pecado. Contudo, o que se acumula como resultado trabalho pode ser gasto em luxo, ócio e transformar-se em pecado. E, para que isso não ocorra, deve-se investir o que foi ganho para gerar mais trabalho. O capitalismo também utiliza essa fórmula para aumentar a riqueza, que tem sua fonte no trabalho. Por isso, para Weber entre os protestantes teria havido maior propensão ao desenvolvimento de atividades capitalistas. ${ }^{18}$

Weber foi buscar a origem da racionalização nos dois pilares da civilização ocidental: a religião e a ciência. Ele procurou demonstrar, contra o materialismo histórico de Marx, que a religião não é uma ideologia, senão que a ética religiosa surgida durante a Reforma contribuiu para o aparecimento do "espírito do capitalismo", como fenômeno que

16 BATTAGLIA, Felice. Filosofia do trabalho. São Paulo: Saraiva, 1958. p. 69.

17 ALBORNOZ, Suzana. O trabalho na balança dos valores. Para onde vai o mundo do trabalho?. Revista Cult, São Paulo, ano 12, n. 139, p. 48, set. 2009.

18 WEBER, Max. A ética protestante e o espírito do capitalismo. São Paulo: Martin Claret, 2012. p. 138141 
funda o modo de produção contemporâneo. Que a relação de causalidade entre a religião o luteranismo e o calvinismo - e a vida material é indireta: isto é, que a religião não causa o capitalismo, senão que fornece as condições para que ele se estabeleça na forma em que o conhecemos. ${ }^{19}$

Embora na Antiguidade se encontrem pensamentos sobre a atividade criadora e o tema comece a tomar importância na modernidade, o trabalho só se afirmaria como objeto da filosofia na época industrial.

O século XVIII avançou na concepção de trabalho, ao caracterizá-lo como valor e fator de produção de riqueza, proporcionando, assim, os elementos estruturantes da nova natureza do trabalho. ${ }^{20}$

No século XIX, sobretudo com Hegel e Marx, é elevado à essência do homem. Tornou-se centro das análises de Karl Marx sobre a alienação do trabalho industrial na economia capitalista.

Marx distingue os homens dos outros animais por meio da atividade vital consciente:

[...] O homem, porém, faz de sua atividade vital um objeto de sua vontade e consciência. Ele tem uma atividade vital consciente. Ela não é uma prescrição com a qual ele esteja plenamente identificado. A atividade vital consciente distingue o homem da atividade vital dos animais: só por esta razão ele é um ente-espécie. Ou antes, é apenas um ser autoconsciente, isto é, sua própria vida é um objeto para ele, porque ele é um ente-espécie. Só por isso, a sua atividade é atividade livre. O trabalho alienado inverte a relação, pois o homem, sendo um ser autoconsciente, faz de sua atividade vital, de seu ser, unicamente um meio para sua existência. $[\ldots]^{21}$

19 THIRY-CHERQUES, Hermano Roberto. Max Weber: o processo de racionalização e o desencantamento do trabalho nas organizações contemporâneas. Revista de Administração Pública, Rio de Janeiro: FGV, p. 906, jul.-ago. 2009.

${ }^{20}$ LANGER, André. O trabalho como essência do homem. Revista Vinculando, Ciudad de México, ago. 2004. Disponível em: <http://vinculando.org>. Acesso em: 24 ago. 2012.

${ }^{21}$ MARX, Karl. Manuscritos econômico-filosóficos. Primeiro manuscrito - Trabalho Alienado, p. 3-14. Disponível em: <http://www.marxists.org/portugues/marx/1844/manuscritos/cap01.htm>. Acesso em: 31 ago. 2012. 
Prossegue Karl Marx dizendo que o trabalhador se converte em escravo do objeto: primeiro, por receber um objeto de trabalho, isto é, receber trabalho, e em segundo lugar por receber meios de subsistência. Assim, o objeto o habilita a existir, primeiro como trabalhador e depois como sujeito físico.

Salienta Marx que o apogeu dessa escravização é ele só poder se manter como sujeito físico na medida em que é um trabalhador, e de só como sujeito físico poder ser um trabalhador:

A alienação do trabalhador em seu objeto é expressa da maneira seguinte, nas leis da Economia Política: quanto mais o trabalhador produz, tanto menos tem para consumir; quanto mais valor ele cria, tanto menos valioso se torna; quanto mais aperfeiçoado o seu produto, tanto mais grosseiro e informe o trabalhador; quanto mais civilizado o produto, tão mais bárbaro o trabalhador; quanto mais poderoso $\mathrm{o}$ trabalho, tão mais frágil o trabalhador; quanto mais inteligência revela o trabalho, tanto mais o trabalhador decai em inteligência e se torna um escravo da natureza. ${ }^{22}$

Do século XIX para cá, com a economia de mercado, toda a produção é centrada na venda e todos os rendimentos derivam de tais vendas. André Langer reporta-se a Max Weber em sua análise do mercado, dizendo que a comunidade de mercado é a relação prática de vida mais impessoal que os homens podem entrar; cada qual está orientado exclusivamente pelo interesse nos bens de troca. ${ }^{23}$

$\mathrm{Na}$ linha da racionalização econômica, esse autor prossegue com as lições de Weber, de que quatro fatores foram essenciais para que o trabalho se tornasse uma mercadoria, ainda que sui generis: primeiro, o custo do trabalho deveria ser calculável e previsível com precisão; segundo, era preciso tornar calculável o seu rendimento para que pudesse ser tratado como uma magnitude material quantificável; terceiro, para ser uma grandeza passível de ser medida, o trabalho deveria ser destacável do trabalhador, isto é, ganhar status de coisa independente; e, quarto, o trabalhador deveria entrar no processo de produção como simples força de trabalho, despojado de sua personalidade, de seus

${ }^{22}$ MARX, Karl. Manuscritos econômico-filosóficos. Primeiro manuscrito - Trabalho Alienado, p. 4-14. Disponível em: $<\mathrm{http}: / /$ www.marxists.org/portugues/marx/1844/manuscritos/cap01.htm>. Acesso em: 31 ago. 2012.

${ }^{23}$ LANGER, André. O trabalho como essência do homem. Revista Vinculando, Ciudad de México, ago. 2004. Disponível em: <http://vinculando.org>. Acesso em: 24 ago. 2012. 
objetivos, de seus desejos próprios, a fim de poder estar a serviço de fins inteiramente alheios aos seus. A racionalização econômica do trabalho foi uma subversão do modo de vida, dos valores, das relações sociais e da natureza, em essência, a invenção no sentido pleno do termo de algo que nunca havia existido. A atividade produtiva foi esvaziada de seu sentido, de suas motivações e de seu para se tornar simples meio de ganhar um salário. Ela deixou de fazer parte da vida para se tornar o meio de "ganhar sua vida". O tempo de trabalho e o tempo de viver foram separados; o trabalho, seus instrumentos, seus produtos adquiriram uma realidade separada da do trabalhador e a depender de decisões estranhas. E assim dá-se o nascimento do trabalho entendido como emprego. ${ }^{24}$

Os estudos sobre o trabalho continuaram a se desenvolver no início do século XX entre discípulos e interlocutores do marxismo, como Marcuse, que complementou a análise do trabalho alienado com a do caráter alienante da produção e do consumo no capitalismo tardio.

Três características do trabalho feitas por Marx são comentadas por Marcuse: a continuidade, a permanência e o caráter penoso. A continuidade e a permanência que caracterizam o trabalho fazem parte do acontecer da vida humana, no sentido de que o homem precisa fazer a sua própria existência, de maneira a aceitar isto como tarefa a ser cumprida. Seu acontecimento é um permanente "fazer acontecer", enquanto o acontecimento da existência animal é um mero "deixar acontecer". 25

E, quanto ao "caráter penoso do trabalho", Marcuse afirma que é o mais exposto a interpretações equivocadas, que o remetem às determinadas condições em que o trabalho é executado, à configuração técnico-social do trabalho, à resistência do material etc. ${ }^{26}$

Karl Marx compreende o trabalho como atividade fundante da humanidade. E o trabalho, sendo a centralidade da atividade humana, desenvolve-se socialmente, sendo o homem um ser social. Sendo os homens seres sociais, a História, isto é, suas relações de produção e suas relações sociais, fundam todo o processo de formação da humanidade.

\footnotetext{
24 LANGER, André. O trabalho como essência do homem. Revista Vinculando, Ciudad de México, ago. 2004. Disponível em: <http://vinculando.org>. Acesso em: 24 ago. 2012.

25 MARCUSE, Herbert. Cultura e sociedade. São Paulo: Paz e Terra, 1998. v. 2, p. 17-18.

26 Idem, ibidem, p. 29 e 47-48.
} 
Esta compreensão e concepção do homem são radicalmente revolucionárias em todos os sentidos, pois é a partir dela que Marx irá identificar a alienação do trabalho como a alienação fundante das demais. E com esta base filosófica Marx compreende todas as demais ciências, com sua noção do real influenciando cada dia mais a ciência por sua consistência.

O conceito de trabalho humano nos dias atuais corresponde simplesmente a "atividade econômica". Trata-se de colonização da teoria econômica sobre a totalidade desse conceito, que nos faz perder o significado geral, mais abrangente, do que representa o trabalho no âmbito da existência humana.

Segundo Herbert Marcuse, a construção do conceito de trabalho feita pela teoria econômica é limitada, não contempla a totalidade, a sua essência. Para esse autor, essa explicação o reduz a uma atividade que se atém ao âmbito da dimensão econômica, cujo modelo é o trabalho assalariado, e, por isso, não dá conta de suas demais dimensões relativas à existência humana. Prossegue Marcuse dizendo que a moderna ciência do trabalho empreende uma tentativa para dar conta do problema do trabalho em toda a sua plenitude, com lastro na biologia como ciência natural. Nesse sentido, o que ultrapassa a dimensão técnico-econômica é essencialmente psicológico. No entanto, alerta, a psicologia não pode fazer justiça com o problema do trabalho, porque o trabalho "é um conceito ontológico, isto é, um conceito que apreende o ser da própria existência humana como tal". 27

Ricardo Antunes, no capítulo "Qual crise da sociedade do trabalho?”, na obra Adeus ao trabalho, ao tratar da dupla dimensão do trabalho concreto e abstrato, cita Heller, quando afirma que o trabalho tem que ser apreendido em seu duplo aspecto: como execução de um trabalho que é parte da vida cotidiana e como atividade de trabalho, como uma objetivação diretamente genérica; diz que Marx se serve de dois termos distintos para melhor caracterizar esta dimensão dupla do trabalho: work e labour. O primeiro (work) realiza-se como expressão do trabalho concreto, que cria valores socialmente úteis. $\mathrm{O}$

27 MARCUSE, Herbert. Cultura e sociedade. São Paulo: Paz e Terra, 1998. v. 2, p. 10. 
segundo (labour) expressa a execução cotidiana do trabalho, convertendo-se em sinônimo de trabalho alienado. ${ }^{28}$

E Hannah Arendt criticou a forma de Marx encarar o trabalho, basicamente pelo fato de a análise marxista priorizar a produção em detrimento da ação. A autora retoma a distinção grega das três atividades fundamentais: labor, trabalho e ação. O labor é a atividade que corresponde ao processo biológico do corpo do homem pela sobrevivência; a condição humana do labor é a própria vida. O trabalho, que corresponde à poiesis grega, é a atividade correspondente ao artificialismo da existência humana; produz um mundo "artificial" de coisas, que têm certa permanência, em oposição à efemeridade da vida humana; a condição humana do trabalho é a mundanidade. Por sua vez, a ação é única atividade que se exerce diretamente entre os homens sem a mediação das coisas ou da matéria, corresponde à condição humana da pluralidade; esta pluralidade é a condição de toda a vida política. ${ }^{29}$

E a tensão permanente em toda a reflexão sobre o trabalho, que ainda aparece na polarização atual entre as interpretações de Marx e Arendt, é que, dada a valorização atribuída ao trabalho-labor, Marx, na perspectiva de Arendt, inverte a hierarquia tradicional; no ápice, Marx não mais situa a ação grega, mas o labor moderno. O ideal do homem moderno passa a ser o ideal do homem trabalhador, aquele que se realiza por meio da profissão, do ofício que realiza; a realização humana se dá no trabalho e não mais fora dele. $^{30}$

Battaglia, valendo-se do dizer de Sombart, diz que o trabalho, no pensamento de Marx, é "a expressão econômica do fato da força produtiva social do trabalho, como fundamento da existência econômica". ${ }^{31}$ Ressalte-se aqui que Battaglia, refutando críticas feitas a Marx de que teria negado a obra do capitalista como trabalhador, entende que a crítica não é adequada, pois o que se condena no pensamento marxista é o lucro

\footnotetext{
28 ANTUNES, Ricardo. Adeus ao trabalho?: ensaio sobre as metamorfoses e a centralidade do mundo do trabalho. São Paulo: Cortez, 2010. p. 83.

29 ARENDT, Hannah. A condição humana. Rio de Janeiro: Forense Universitária, 1991. p. 15.

30 LANGER, André. O trabalho como essência do homem. Revista Vinculando, Ciudad de México, ago. 2004. Disponível em: <http://vinculando.org>. Acesso em: 24 ago. 2012.

31 BATTAGLIA, Felice. Filosofia do trabalho. São Paulo: Saraiva, 1958. p. 187.
} 
extraordinário do empreendedor, que realiza a expoliação do operário; diz que Marx não exclui que em uma sociedade futura o trabalho de direção esteja no mesmo plano do trabalho manual. A crítica que esse autor faz a Marx é quanto à parcialidade do cientificismo econômico, na elisão deliberadamente desejada dos motivos éticos. ${ }^{32}$ Concorda que é vital a exigência do marxismo no sentido de uma crescente socialização, contudo não é menos vital a exigência de liberdade, o respeito ético pelo indivíduo, segundo Battaglia, herdado da "luminosa tradição cristã". 33

Permanece válida e definitiva a análise crítica do trabalho no mundo industrial feita por Karl Marx, como denúncia da exploração e da alienação do trabalho no século XIX. Marx não fez somente a análise exaustiva das relações de trabalho na sociedade capitalista, como acrescentou conceitos novos, como trabalho concreto e abstrato, trabalho morto, trabalho vivo. O trabalho é o esforço do homem para regular seu metabolismo com a natureza, e assim, por meio do trabalho, o homem se transforma a si mesmo.

Fábio Konder Comparato, ao tratar de despersonalização de seres humanos, que ocorreu no Gulag soviético e no Lager nazista, diz que,

[...] analogamente, a transformação das pessoas em coisas realizou-se de modo menos espetacular, mas não menos trágico, com o desenvolvimento do sistema capitalista de produção. Como denunciou Marx, ele implica a reificação ("Verdinglichung") das pessoas; ou melhor, a inversão completa da relação pessoa-coisa. Enquanto o capital é, por assim dizer, personificado e elevado à dignidade de sujeito de direito, o trabalhador é aviltado à condição de mercadoria, de mero insumo no processo de produção, para ser ultimamente, na fase de fastígio do capitalismo financeiro, dispensado e relegado ao lixo social como objeto descartável. ${ }^{34}$

De todo modo, impõe-se definir o conceito de trabalho. Battaglia diz que existem dificuldades além das etimológicas ou léxicas, pois se trata de um conceito complexo, eis que implica os mais diversos aspectos da vida, e por isso está voltado para as mais diversas

32 BATTAGLIA, Felice. Filosofia do trabalho. São Paulo: Saraiva, 1958. p. 187-188.

33 Idem, ibidem, p. 194.

34 COMPARATO, Fábio Konder. A afirmação histórica dos direitos humanos. São Paulo: Saraiva, 2003. p. 23-24. 
ciências, e cada uma delas se ocupa e o enquadra diversamente, de forma mais ou menos central, porém sempre envolto de interesse. Como nosso estudo está centrado no homem, cumpre delimitar os campos das ciências que se ocupam do plano humano.

Felice Battaglia infere que trabalho é atividade do produzir e coisa produzida, e também a relação produtiva do sujeito e do objeto enquanto medeia fadiga ou pena; mas esta concepção não é exata, porquanto se o trabalho tem aspectos penosos, produz também alegria, "tanto que há uma alegria no trabalho". ${ }^{35}$ Há a fisiologia do trabalho, em que o homem pode considerar-se como um motor que produz rendimento: introduz comida e transforma-a em energia, trabalha.

Esse autor aponta a divisão existente entre os economistas quanto ao trabalho; a economia tem várias correntes, mas em geral ensina que o trabalho é um dos três fatores da produção, da atividade dirigida para produzir bens econômicos: terra, capital, trabalho e procura aprofundar a compreensão do trabalho enquanto serve para a produção de bens econômicos, de utilidade econômica. ${ }^{36}$

No entanto, alerta Battaglia, muitas são as dificuldades para permanecer no plano econômico. Questiona: se o trabalho é atividade voltada tão somente para a criação de bens úteis, econômicos, o que pensar do trabalho que não cria bens, mas se desenvolve no próprio sujeito, como a atividade do pensamento, arte, religião, filosofia? São atividades que criam, pois nada é mais criador que o pensamento, mas que não são medidas segundo as noções de utilidade econômica, não constituindo bens econômicos. Deixa-nos o questionamento quanto a essas atividades que não se volvem para o exterior, desenvolvemse no espírito e criam bens e valores que não são econômicos, se cabem no conceito de trabalho. ${ }^{37}$

Responde Battaglia dizendo que existe uma noção de trabalho que atinge a filosofia. Sustenta que as noções parciais do trabalho, nos aspectos da mecânica e da física, biológica e fisiológica, técnica e econômica, se integram no plano filosófico. E, se para a

\footnotetext{
35 BATTAGLIA, Felice. Filosofia do trabalho. São Paulo: Saraiva, 1958. p. 19.

${ }^{36}$ Idem, ibidem, p. 20.

37 Idem, p. 21-22.
} 
conceituação de trabalho importam somente certos aspectos, como transformação da energia e produção dos bens, a filosofia releva todos os aspectos para unificá-los em uma noção integral: assim, o conceito de trabalho, como essência do homem, que é atividade, em si atinge o objeto e o constitui. Dessa forma, o ato de consciência e de criação, que nos reporta ao espírito, já é trabalho; "não há existência e produção de bens, não há atividade voltada para o exterior, que não pressuponha aquele ato, já trabalho, enquanto atividade desdobrada". 38

Aqui podemos exemplificar com determinadas atividades que não são desenvolvidas para a produção de bens econômicos, e nem por isso deixam de ser trabalho, como é o caso do trabalho voluntário, desenvolvido, por exemplo, para atendimento de doentes. Trata-se de atividade voltada para o exterior, de interesse social, com capacidade para criar valores, como o de bem-estar, físico e psicológico, das pessoas atendidas; porém, tais valores não são econômicos, tampouco por isso essas atividades deixam de ser trabalho.

Felice Battaglia diz que se insiste muito em que a nossa civilização é a civilização do trabalho, porquanto nasce, desenvolve-se e progride no trabalho, por ter em grande apreço o trabalho como atividade; fala-se ainda na dignidade do trabalho, no dever do trabalho, no direito ao trabalho, afirmando-se, com isto, que o trabalho é um valor na ordem ético-jurídica conferido ao homem e que o homem eleva. ${ }^{39}$

De acordo com o enfoque da ergonomia, o "trabalho é uma atividade que convoca o corpo inteiro e a inteligência para enfrentar o que não é dado pela estrutura técnicoorganizacional". 40

Trata-se de ciência que passou por transformações notáveis no estudo do trabalho, destaca Edith Seligmann Silva; a ergonomia examinava o trabalho concreto e as necessidades para que fosse adaptado ao homem sem afetar a sua saúde e o desempenho

38 BATTAGLIA, Felice. Filosofia do trabalho. São Paulo: Saraiva, 1958. p. 23.

39 Idem, ibidem, p. 15.

40 ASSUNÇÃO, Ada Ávila; ANTUNES LIMA, Francisco de Paula. A contribuição da ergonomia para a identificação, redução e eliminação da nocividade do trabalho. In: MENDES, René et al. Patologia do trabalho. São Paulo: Atheneu, 2005. p. 1768. 
humanos. Diz essa autora que, embora a ergonomia tenha se mantido por muito tempo circunscrita a uma psicofisiologia e neurofisiologia de raízes dominantemente positivistas, as transformações ocorreram especialmente nos países em que as correlações de forças entre empregadores e trabalhadores favoreceram a efetiva participação dos últimos nas investigações ergonômicas e na proposição de soluções às inadequações constatadas. ${ }^{41}$

E em uma análise efetuada ao longo de sua obra, que entrelaça o campo das ciências sociais com o das ciências da saúde, Edith Seligmann Silva diz que o trabalho "é uma instância social que, na atualidade, passou a ser examinada com maior atenção quanto a seu papel no processo saúde-transtorno mental. [...] O trabalho, conforme a situação, tanto poderá fortalecer a saúde mental quanto vulnerabilizá-la [...]”. ${ }^{42}$

Com a evolução das concepções filosóficas expostas, pode-se verificar a busca da valorização do trabalhador por intermédio da minimização dos aspectos perversos do trabalho.

E, seguindo a linha histórica traçada por Felice Battaglia, diz esse autor que pode apresentar algumas indicações para a determinação do conceito de trabalho como essencial à moderna visão da vida. Procura destacar a significação individual do trabalho e afirma que somente o esclarecimento árduo da personalidade na ética, na medida em que a pessoa é o indivíduo qualificado, entendido no plano moral, pode levar a um adequado conceito de trabalho. Define trabalho, embora de forma não exaustiva, como

[...] todo desdobramento do espírito, enquanto atividade, sejam os seus fins meramente teóricos, sejam, ao contrário, práticos. $\mathrm{O}$ ato do espírito que de qualquer maneira entenda a si próprio ou às coisas, que as coisas institua ou transforme, é trabalho. ${ }^{43}$

No contexto do capitalismo, alerta Jorge Souto Maior, o trabalho significa mero fator de sobrevivência, e a exploração do trabalho alheio constitui fonte de riqueza. Por

\footnotetext{
${ }^{41}$ SILVA, Edith Seligmann. Trabalho e desgaste mental: o direito de ser dono de si mesmo. São Paulo: Cortez, 2011. p. 84.

${ }^{42}$ Idem, ibidem, p. 35.

43 Idem, p. 200.
} 
isso, dependendo das condições em que o trabalho é executado, o trabalho pode representar a completa negação da condição humana. ${ }^{44}$

Alerta esse autor que quanto mais complexas as relações sociais, mais contradições o mundo do trabalho pode trazer: a) a primeira contradição está na preocupação com a limitação do trabalho em um mundo que tem como característica marcante a inquietação com o desemprego; b) o avanço tecnológico está roubando o trabalho do homem e, por outro lado, é a tecnologia que tem escravizado o homem ao trabalho; c) a tecnologia proporciona ao homem uma possibilidade quase infinita de se informar, por outro lado, é esta mesma tecnologia que torna o homem um ser dependente dos meios de informação. ${ }^{45}$

A ideia já sedimentada de que o "trabalho dignifica o homem", ressalva Souto Maior, é desvirtuada quando se pensa no trabalho explorado em uma relação capitalista; nessa relação, e ainda mais sem uma noção de direito, quanto mais se trabalha, mais dignidade se perde, embora, de forma paradoxal, ficar privado de todo o trabalho possa colocar em risco a própria sobrevivência.

Esse paradoxo é explicitado por Souto Maior, quando diz que o trabalho é extremamente significativo para as pessoas, a ponto de haver discriminação com relação a quem não trabalha. A sociedade que discrimina é hipócrita, pois no fundo o que todo mundo quer é ficar rico sem trabalhar ou mesmo enriquecer trabalhando, para, o quanto antes, parar de trabalhar. Reporta-se ao dito pelo Barão de Itararé: “O trabalho enobrece o homem, mas depois que o homem se sente nobre não quer mais trabalhar". ${ }^{4}$

A crítica à ideia "o trabalho enobrece", oriunda da influência religiosa, é a reflexão que faz Lya Luft. A autora ressalta a dicotomia ínsita nesse pensamento, e afirma que o trabalho que dá valor ao ser humano e algum sentido à vida pode, por outro lado, deformar e destruir. Prossegue a escritora:

\footnotetext{
${ }^{44}$ SOUTO MAIOR, Jorge Luiz. Curso de direito do trabalho: teoria geral do direito do trabalho. São Paulo: LTr, 2011. v. 1, Parte I, p. 39.

${ }^{45}$ Idem, ibidem, p. 39.

${ }^{46}$ Idem, p. 41.
} 
"O trabalho enobrece" é uma dessas frases feitas que a gente repete sem refletir no que significam, feito reza automatizada.

Outra é "A quem Deus ama, ele faz sofrer", que fala de uma divindade cruel, fria, que não mereceria uma vela acesa sequer. Sinto muito: nem sempre trabalhar nos torna mais nobres, nem sempre a dor nos deixa mais justos, mais generosos. O tempo para contemplação da arte e da natureza, ou curtição dos afetos, por exemplo, deve enobrecer bem mais. Ser feliz, viver com alguma harmonia, há de nos tornar melhores do que a desgraça. A ilusão de que o trabalho e o sofrimento nos aperfeiçoam é uma ideia que deve ser reavaliada e certamente desmascarada.

$[\ldots]$

O desprezo pela alegria e pelo lazer espalha-se entre muitos de nossos conceitos, e nos sentimos culpados se não estamos em atividade, na cultura do corre-corre e da competência pela competência, do poder pelo poder, por mais tolo que ele seja.

Assim como o sofrimento pode nos tornar amargos e até emocionalmente estéreis, o trabalho pode aviltar, humilhar, explorar e solapar qualquer dignidade, roubar nosso tempo, saúde e possibilidade de crescimento.

$[\ldots]$

Quanto tempo o meu trabalho - se é que temos escolha, pois a maioria de nós dá graças a Deus se consegue trabalhar por um salário vil - me permite para lazer, ou o que eu de verdade quero, se é que paro para refletir sobre isso? Quanto tempo eu me dou para viver? Quanto sobra para meu crescimento pessoal, para tentar observar o mundo e descobrir meu lugar nele, por menor que seja, ou para entender minha cultura e minha gente, para amar minha família?

$[\ldots]$

Servos de uma culpa generalizada, fabricamos caprichosamente cada elo do círculo infernal de nossa infelicidade e alienação. Essas frases feitas, das quais aqui citei só duas, podem parecer banais. Até rimos delas, quando alguém nos leva a refletir a respeito. Mas na verdade são instrumento de dominação de mentes: sofra e não se queixe, não se poupe, não se dê folga, mate-se trabalhando, seja humilde, seja pobre, sofrer é o nosso destino, darás à luz com dor - e todo o resto da tola e desumana lavagem cerebral de muitos séculos, que a gente em geral nem questiona mais. $^{47}$

Contudo, a ideia do trabalho como fator dignificante da pessoa humana e como elemento de socialização do indivíduo impera culturalmente, salienta Jorge Souto Maior, e por isso é um desafio falar em "direito ao não trabalho". Refere-se a esse direito como um bem da vida, numa perspectiva técnico-jurídica e não na linha adotada por Domenico de

\footnotetext{
${ }^{47}$ LUFT, Lya. Trabalhar e sofrer. Veja, 20 jan. 2010, p. 24.
} 
Masi. Assim, o direito ao não trabalho não significa não trabalhar completamente, e sim trabalhar menos, até o nível necessário à preservação da vida privada e da saúde. ${ }^{48}$

Afirma Souto Maior que o problema relevante para a avaliação filosófica do trabalho é o de solucionar o grande paradoxo do mundo do trabalho moderno, que nos desafia: enquanto uma grande parcela da população não tem acesso ao trabalho, e isto põe em risco a sua sobrevivência, outra parcela, não menos considerável, está se matando de tanto trabalhar ou alienando-se no trabalho. ${ }^{49}$

É incontestável que o trabalho representa um valor fundamental para o ser humano, reconhece esse autor; no entanto o trabalho inserido nas relações capitalistas, servindo à reprodução do capital, ao mesmo tempo em que o trabalhador tem um sentimento de pertencimento a esta sociedade, faz com que esse trabalhador perca a noção de sua exploração. Assim, valorizar socialmente o trabalho não é fixar o valor que ele possui nas relações de troca em um regime capitalista, mas, sim, estabelecer um padrão de análise que priorize o ser humano em detrimento do interesse econômico, conclui Souto Maior. ${ }^{50}$

Pode-se dizer que o trabalho é atividade humana, vital e consciente, por meio da qual o homem assegura sua subsistência e altera sua relação com a natureza; é um dever, absoluto e inderrogável para o homem, bem como um direito; envolve aspectos e esforços físicos e mentais; é causa de realização, de prazer e alegria, bem como de angústia, insatisfação e adoecimento, físico e mental.

E ainda que se reconheça como trabalho aquele desvinculado da noção eminentemente econômica, o presente estudo enfoca o trabalho realizado mediante um ganho, o trabalho do qual depende o homem para sobreviver. Nesse sentido, a sua falta pode provocar desespero, desequilíbrio emocional; quando realizado, pode ser causa de satisfação, de realização, de prazer, de alegria; por outro lado, pode propiciar angústia, ansiedade, insatisfação, exasperação. A respeito do trabalho podem ser ouvidas

\footnotetext{
${ }^{48}$ SOUTO MAIOR, Jorge Luiz. Curso de direito do trabalho: teoria geral do direito do trabalho. São Paulo: LTr, 2011. v. 1, Parte I, p. 41.

49 Idem, ibidem, p. 42.

${ }^{50}$ Idem, p. 42.
} 
declarações que denotam emoções antagônicas: alguém pode "amar" o trabalho, outrem "odiar"; tudo vai depender de vários fatores, como a tarefa prescrita, o meio ambiente de trabalho, os relacionamentos pessoais nele envolvidos; as características pessoais e comportamentais do chefe e dos subordinados, bem como da forma como é organizado o trabalho.

A atividade de trabalho não pode ser reduzida à prescrição de tarefas, trata-se de "tomada de iniciativa para fazer o sistema funcionar". 51

O trabalho, fundamental para o ser humano, deve servir à preservação à elevação da condição humana e não como fator de destruição da dignidade. ${ }^{52}$

Nesse sentido, todos têm papel a desempenhar: os operadores do direito, os detentores do poder, econômico e político, portanto, os empregadores e o governo, enfim, toda a sociedade, para que seja assegurada a preservação da integridade física, a proteção à saúde, a conquista e a manutenção da qualidade de vida dos trabalhadores.

É o que procuraremos tratar no capítulo seguinte.

\subsubsection{Evolução histórica: da escravidão ao trabalho remunerado}

Escravidão é o regime social em que há sujeição do homem, e sua força de trabalho é entendida como propriedade privada de outrem. ${ }^{53}$ É a primeira forma da sociedade dividida entre dominados e dominadores. A origem da escravidão perde-se nos tempos e coincide com o início da civilização. Antes, os prisioneiros feitos nas guerras eram mortos. A descoberta de que podiam ser poupados e colocados para trabalhar teve importância semelhante à domesticação dos animais. Nas sociedades antigas, em que não havia ainda clara separação entre propriedade pública e propriedade privada, os escravos eram usados nos trabalhos desenvolvidos em uma economia patriarcal, ao lado dos seus senhores, ou eram propriedade do Estado ou dos templos.

\footnotetext{
51 GUÈRIN, F. et al. Compreender o trabalho para transformá-lo: a prática da ergonomia. São Paulo: Blücher: Fundação Vanzolini, 2010. p. XII.

52 Idem, ibidem.

53 GRANDE Enciclopédia Larousse Cultural. São Paulo: Larousse, 1995; Nova Cultural, 1998.
} 
Na Grécia o uso dos escravos se generalizou, mas o número não era elevado até o fim do século V a.C. A origem do termo escravidão vem do grego bizantino skablos. Em algumas cidades-estado gregas havia a escravidão por dívidas; quando uma pessoa devia para outra e não podia quitar sua dívida, transformava-se em escrava do credor por um determinado tempo. Em Atenas, este tipo de escravidão foi extinto somente no século VI a.C, após as reformas sociais promovidas pelo legislador Sólon.

Os árabes deram início ao tráfico de escravos africanos. Ocorre que nas sociedades muçulmanas a dominação deu-se sobre brancos e negros, indistintamente, e os escravos eram destinados sobretudo aos trabalhos domésticos, trabalhando para a família. Como leciona o Prof. Fábio Konder Comparato, "Para os europeus, diversamente, o tráfico visou, desde o início, tão só à população negra, e inseriu-se no empreendimento das culturas agroexportadoras, organizadas em forma capitalista nos grandes domínios rurais do continente americano". 54

A escravidão, como um fenômeno que transcendeu os limites dos Estados nacionais, estendendo-se praticamente em todo o continente americano, é tratada por Robin Blackburn, que afirma que "os estados modernos tiveram uma parcela de responsabilidade pela crueldade do tráfico transatlântico de escravos e pelo posterior funcionamento impiedoso e desumano dos sistemas de escravidão. Os monarcas portugueses promoveram e licenciaram o comércio de escravos na África desde meados do século XV. [...]". ${ }^{55}$

Segundo esse autor, as plantations são formas específicas de organizar a produção agrícola para fins comerciais, seguindo a tradição já estabelecida no meio acadêmico; no Brasil tornaram-se grandes produtoras nas últimas décadas do século XVI; no Novo Mundo, os estados coloniais nutriam-se de uma "escravidão civil" ligada às redes comerciais espalhadas pelo Atlântico e além dele. Em 1713, a escravidão já se estabelecera com base racial nas grandes plantações do Brasil, do Caribe e da América do Norte. Os

\footnotetext{
${ }^{54}$ COMPARATO, Fábio Konder. A afirmação histórica dos direitos humanos. São Paulo: Saraiva, 2003. p. 196.

55 BLACKBURN, Robin. A construção do escravismo no Novo Mundo. Rio de Janeiro: Record, 2003.
} 
estadistas que sempre se preocuparam com o ouro e a prata aos poucos perceberam que o comércio de produtos das plantations podia ser muito mais valioso". 56

Apesar da divergência das cifras entre historiadores, o número mais aceitável de pessoas escravizadas por meio do tráfico transatlântico para as Américas varia entre doze e treze milhões; o maior contingente, de cerca de três milhões e meio, ficou no Brasil. ${ }^{57}$

Assim, o tráfico de escravos foi um dos principais fatores de acumulação de capitais que permitiu a eclosão do capitalismo industrial no Ocidente europeu e, no dizer de Comparato, as Américas conheceram o mais vasto sistema de escravidão jamais organizado em toda a História. Ensina esse professor que a repressão ao tráfico somente teve início no século XIX. O tratado de aliança e amizade firmado entre a Inglaterra e Portugal e a partir daí os tratados que se sucederam proibiam a compra de escravos ou seu tráfico; por meio da convenção assinada em Londres em 1817, Portugal reconhece à Inglaterra o direito de visita e busca das naus portuguesas suspeitas de realizarem tráfico negreiro.

Tratados de Paz de Paris de 1814 e 1815, bem como as Declarações do Congresso de Viena de 1815 e a Declaração de Verona de 1822, reconheceram que o tráfico de escravos violava “os princípios de justiça e de humanidade". Depois, em 1831 e 1833, tratados são firmados entre França e Grã-Bretanha, em 1841 o tratado de Londres e o tratado de Washington de 1862 previram repressão ao transporte de escravos africanos por via marítima, estabeleceram poderes recíprocos de visita, busca e captura de navios suspeitos de praticarem o tráfico.

Em 1822 o Brasil torna-se independente de Portugal, e o regime escravocrata passa a ser mais combatido depois da independência. Em 1826 celebra com a Inglaterra convenção estabelecendo que tráfico praticado três anos após as ratificações seria equiparado à pirataria. O parlamento britânico vota em 1845 o "bill Aberdeen", sendo os cruzadores ingleses autorizados a apresar os navios negreiros brasileiros, mesmo em altomar e submetê-los a julgamento. Em decorrência dessas pressões internacionais, a

\footnotetext{
${ }^{56}$ BLACKBURN, Robin. A construção do escravismo no Novo Mundo. Rio de Janeiro: Record, 2003. p. 41.

57 Idem, ibidem, p. 15.
} 
Assembleia-Geral do Rio de Janeiro votou a Lei Euzébio de Queiroz, proibindo o tráfico negreiro e estabelecendo severas punições aos infratores.

A extinção do tráfico africano veio acentuar e aprofundar as contradições do regime escravista; a escassez de braços e o desequilíbrio demográfico entre as diferentes regiões do país acrescentam-se aos problemas já existentes e fazem com que se procure uma solução, que será encontrada na imigração europeia. A corrente imigratória se intensifica depois de 1850 e assim passam a coexistir, nas lavouras de café, trabalhadores escravos e europeus livres.

A escravidão é abolida nos Estados Unidos da América em 1865. Na época, a posição internacional do Brasil acentua as contradições ideológicas do escravismo, uma vez que, depois de abolida a escravidão nos EUA, será com Cuba o único país da civilização ocidental a admiti-la. ${ }^{58}$

No Brasil, a abolição deu-se por meio da Lei Áurea, a Lei n. ${ }^{\circ} 3.353$, de 13 de maio de 1888. Do ponto de vista político a Lei Áurea foi positiva, mas do ponto de vista social pouco alterou a realidade dos trabalhadores escravizados. Assim como os índios, os negros não tiveram a oportunidade de, na prática, gozar do benefício da liberdade, com o simples advento da abolição formal. Índios e negros, por meio da opressão colonizadora e da escravidão, foram arrancados de suas terras, perderam sua identidade, cultura, língua, costumes, tradições, religião, não tinham possibilidade de voltar às suas origens ou de conquistar um espaço digno para viver. Por este motivo muitos continuaram nas fazendas de seus antigos donos, como escravos, por falta de opção de trabalho, de qualificação profissional e preconceito racial até que lhe sobreviessem os fins de seus dias de vida.

A Assembleia da Liga das Nações aprova em 25 de setembro de 1926 convenção sobre a escravidão e o tráfico de escravos; e em 1932 entra em vigor no plano internacional a Convenção n. ${ }^{\circ}$ 29, sobre a abolição do trabalho forçado, ratificada pelo Brasil somente em 1957.

58 PRADO JUNIOR, Caio. História econômica do Brasil. São Paulo: Brasiliense, 1987. p. 176. 
A terminologia utilizada para denominar "trabalho escravo" varia na doutrina; são usadas as expressões "trabalho análogo à condição de escravo"; "trabalho forçado", ou "trabalho escravo contemporâneo"; "escravidão por dívidas", "trabalho obrigatório", "redução à condição análoga à de escravo". Como nos ensina o Prof. Ronaldo Lima dos Santos, "independentemente da denominação adotada, [...], em todas as hipóteses levantadas, constatamos flagrantemente a sempre presença de vícios de vontade, desde a arregimentação do trabalhador, para a prestação dos serviços. Os mais diversos métodos de coação, simulação, fraude, dolo, indução a erro, são empregados para cercear a vontade do empregado e obrigá-lo a prestação de serviços contra a sua vontade". 59

Jairo Lins de Albuquerque Sento-Sé considera mais apropriada a expressão "trabalho escravo contemporâneo". ${ }^{60}$ Esse autor conceitua o trabalho escravo contemporâneo como

[...] aquele em que o empregador sujeita o empregado a condições de trabalho degradantes, inclusive quanto ao meio ambiente em que irá realizar a sua atividade laboral, submetendo-o, em geral, a constrangimento físico e moral, que vai desde a deformação do seu consentimento ao celebrar o vínculo empregatício, passando pela proibição imposta ao obreiro de resilir o vínculo quando bem entender, tudo motivado pelo interesse mesquinho de ampliar os lucros às custas da exploração do trabalhador. ${ }^{61}$

Trabalho realizado em condição análoga à de escravo é o mesmo que dizer que o trabalho é forçado, conforme a proteção legal internacional, como se vê pelas disposições da Convenção n. 29 da Organização Internacional do Trabalho (OIT). ${ }^{62}$

Nesse passo, o fator determinante para caracterizar trabalho análogo ao de escravo é o cerceamento de liberdade. O trabalhador escravo sofre três modos de coação, a saber: a) econômica; b) moral/psíquica; c) física. Tal exploração retira do ser humano a

59 SANTOS, Ronaldo Lima dos. A escravidão por dívidas nas relações de trabalho no Brasil contemporâneo. Revista do Ministério Público do Trabalho, São Paulo: LTr, ano XIII, n. 26, p. 55-56, 2003.

${ }^{60}$ SENTO-SÉ, Jairo Lins de Albuquerque. Trabalho escravo no Brasil. São Paulo: LTr, 2001. p. 25.

${ }^{61}$ Idem, ibidem, p. 27.

62 “Art. 2 - 1. Para os fins da presente convenção, a expressão 'trabalho forçado ou obrigatório' designará todo trabalho ou serviço exigido de um indivíduo sob ameaça de qualquer penalidade e para o qual ele não se ofereceu de espontânea vontade." 
cidadania, e infringe os princípios constitucionais da dignidade da pessoa humana e do valor social do trabalho.

Trabalho degradante é o trabalho humilhante, que priva o trabalhador do seu status de cidadão, nega direitos inerentes à cidadania e rebaixa sua condição humana.

Na conceituação de trabalho escravo utilizada pela OIT, toda forma de trabalho escravo é trabalho degradante, mas a recíproca nem sempre é verdadeira. O que diferencia um conceito do outro é a liberdade. Quando falamos de trabalho escravo, tratamos da prática de um delito que cerceia a liberdade dos trabalhadores, por meio de quatro fatores: apreensão de documentos, presença de guardas armados e "gatos" de comportamento ameaçador, por dívidas ilegalmente impostas ou pelas características geográficas do local, que impedem a fuga. ${ }^{63}$

Cabe distinguir os conceitos anteriormente citados do trabalho penoso. O trabalho penoso não retrata cerceamento do direito à liberdade; este não se caracteriza pela arregimentação de trabalhadores, mas pela natureza ou condição e execução da atividade de trabalho. ${ }^{64}$

Por fim, o trabalho forçado caracteriza-se pela presença dos seguintes elementos, de forma concomitante, entre outros: aliciamento de mão de obra por "gatos"; servidão por dívida; e cerceamento do direito à liberdade, conforme será detalhado a seguir.

No que tange ao trabalho forçado, em particular na zona rural, na visão do procurador Jairo Lins de Albuquerque Sento-Sé,

[...] a mola propulsora da existência do trabalho escravo na zona rural do Brasil é a sua estreita relação com o interesse econômico. Vale dizer, o trabalho escravo é utilizado como instrumento para ampliar os lucros dos empresários rurais à custa da exploração gananciosa do trabalhador campesino. Nesse diapasão, aponta-se o aproveitamento das crianças na atividade laboral rural como um exemplo típico desta cruel realidade. ${ }^{65}$

\footnotetext{
63 Disponível em: <http://www.oitbrasil.org.br>. Acesso em: 10 jul. 2010.

64 MARQUES, Christiani. A proteção ao trabalho penoso. São Paulo: LTr, 2007. p. 30.

65 SENTO-SÉ, Jairo Lins de Albuquerque. Trabalho escravo no Brasil. São Paulo: LTr, 2001.
} 
Os setores que mais escravizam atualmente são: siderurgia, agricultura, pecuária, as carvoarias e extração de minérios. Para ilustrar como ocorrem a utilização e a exploração do trabalho escravo na cadeia produtiva, citamos as carvoarias da Amazônia, que são controladas por siderúrgicas com sede nos estados do Maranhão e do Pará. Algumas siderúrgicas são de propriedade de gigantes da economia, com atuação em quase todo o território nacional e também no exterior; alguns desses grupos são acusados pelo Ministério Público do Trabalho de explorarem mão de obra escrava em carvoarias ilegais. Esse carvão é utilizado na produção do ferro-gusa exportado aos Estados Unidos para a produção do aço, que por sua vez é matéria-prima de automóveis e diversos outros produtos. ${ }^{66}$ Há também exploração de trabalho análogo ao de escravo no setor produtor de açúcar e de álcool.

O Ministério do Trabalho e Emprego (MTE), por meio da Portaria n. ${ }^{\circ}$ 540/2004, instituiu a chamada "lista suja", cadastro de empregadores envolvidos em flagrantes de trabalho escravo. As empresas que têm seus nomes incluídos nessa lista se sentem pressionadas, pois sofrem as consequências negativas, como a queda de suas ações na Bolsa de Valores e a perda de financiamentos públicos e de compradores. No mais das vezes, a empresa denunciada reputa a prática inquinada às terceirizadas, procurando eximir-se de responsabilidade, o que, lamentavelmente, por vezes é acolhido pelo Judiciário. Saliente-se que o Grupo Especial de Fiscalização Móvel - "Grupo Móvel” do Ministério do Trabalho e Emprego atua no resgate dos trabalhadores escravizados. ${ }^{67}$

De acordo com o Procurador do Ministério Público do Trabalho, Loris Rocha Pereira Júnior,

O trabalhador escravo é o produto da desigualdade, da distribuição de renda, é o produto da desigualdade até mesmo na distribuição de terras neste país. Ele é também o resultado da ineficácia, da ineficiência dos nossos poderes constituídos, do Ministério Público, do Poder Judiciário, e do Poder Executivo. ${ }^{68}$

\footnotetext{
${ }^{66}$ Disponível em: <www.observatoriosocial.org.br>. Acesso em 10 jul. 2010.

${ }^{67}$ FÓRUM Social Mundial 2003. Anais da oficina trabalho escravo: uma chaga aberta - Brasília: OIT, 2003. p. 24.

${ }^{68}$ Idem, p. 25.
} 
Ronaldo Lima dos Santos afirma que a escravidão por dívidas é instituto há muito conhecido na história da humanidade, e é o modo peculiar e mais conhecido de forma escravizatória no Brasil contemporâneo. ${ }^{69}$

Aliciados pelos "gatos", iludidos com a promessa de emprego, com o pagamento de salário digno, embarcam os trabalhadores para laborar em local distante de suas regiões de origem. Seus documentos são retidos assim que chegam ao lugar de prestação de serviços; o arregimentador adianta quantia em dinheiro para os trabalhadores fazerem frente às suas necessidades básicas e às de sua família; esta será sua primeira dívida perante o empregador. Os pagamentos não são efetuados em dinheiro, e sim quase todo in natura, por meio de alimentos, vestuários adquiridos no armazém do proprietário.

Diz Jairo Lins de Albuquerque Sento-Sé que esta é uma prática conhecida como truck-system ou sistema de barracão, pois no barracão são vendidos aos trabalhadores os diversos produtos úteis, incluindo ferramentas que serão utilizadas no trabalho, bem como remédios e materiais de higiene e limpeza. O endividamento prossegue, pois os trabalhadores estão em local ermo, tolhidos da liberdade de ir e vir; o empregador entrega os bens in natura, por meio de vales ou "borós", a serem descontados do salário no final do mês. $^{70}$ Observe-se que os produtos são vendidos por preço acima dos de mercado, acentuando-se a expoliação.

Sento-Sé assevera que

[...] na quase totalidade dos casos, o "gato" não passa de um simples intermediário do dono da terra, seu capataz e preposto, falando em seu nome e na defesa de seus interesses. Em geral, não tem idoneidade financeira e econômica para celebrar tantas relações jurídicas de emprego quantos são os obreiros contratados. Ao contrário, goza de uma condição de miserabilidade que pouco se distancia daquela vivida pelos rurícolas. O objetivo é justamente escamotear a realidade, impedindo a identificação de uma relação de emprego entre o proprietário rural e os diversos campesinos. ${ }^{71}$

69 SANTOS, Ronaldo Lima dos. A escravidão por dívidas nas relações de trabalho no Brasil contemporâneo. Revista do Ministério Público do Trabalho, São Paulo: LTr, ano XIII, n. 26, p. 56-58, 2003.

70 SENTO-SÉ, Jairo Lins de Albuquerque. Trabalho escravo no Brasil. São Paulo: LTr, 2001. p. 49-50.

71 Idem, p. 53-54. 
Explicita tal autor que o mascaramento da realidade se dá com a contratação por empreitada, contrato de natureza civil, visando eximir o proprietário rural da obrigação do pagamento dos direitos trabalhistas e sociais oriundos da relação de emprego, regida pela CLT.

Além da prática ilícita do trabalho forçado, ensina Ronaldo Lima dos Santos que a escravidão por dívidas fere os princípios da intangilibilidade salarial (artigo 462, caput, da CLT), da irredutibilidade do salário (artigo 7. ${ }^{\circ}$, inciso VI, da Constituição Federal); e infringe a vedação à prática do truck system (artigo 462, $\S \S 2 .^{\circ}$ e $3 .^{\circ}$, CLT), bem como a determinação do pagamento da prestação em espécie do salário em moeda corrente (artigo 463 da CLT). Há ainda violação aos dispositivos reguladores do trabalho rural, contidos na Lei n. ${ }^{0}$ 5.889, de 08.06.1973. As condutas tipificam os crimes definidos no Código Penal, entre outros, o da redução de alguém à condição análoga à de escravo, nos termos do artigo 149 desse diploma legal. ${ }^{72}$

E à luz dessa ordem constitucional, para o Prof. Ronaldo Lima dos Santos, escravizar é

[...] violar direitos fundamentais e difusos da sociedade, consagrados na Constituição Federal de 1988, entre os quais se destacam: a proteção à dignidade humana (art. 1. $\left..^{\circ}, \mathrm{III}\right)$; os valores sociais do trabalho e da livreiniciativa (art. $\left.1^{\circ}, \mathrm{IV}\right)$; a inviolabilidade do direito à vida, à liberdade, à igualdade, a segurança (art. 5. ${ }^{\circ}$, caput); a construção de uma sociedade livre, justa e solidária (art. 3. $\left.{ }^{\circ}, \mathrm{I}\right)$; o princípio da legalidade (art. 5. $\left..^{\circ}, \mathrm{II}\right)$; não submissão à tortura ou tratamento desumano ou degradante (art. $5 .^{\circ}$, III); a inviolabilidade da intimidade; da vida privada, da honra e da imagem (art. 5. $\left.{ }^{\circ}, \mathrm{X}\right)$; a liberdade de exercício de trabalho, ofício ou profissão (art. 5. ${ }^{\circ}, \mathrm{XIII}$ ); a liberdade de locomoção (art. 5. ${ }^{\circ}, \mathrm{XV}$ ); a função social da propriedade (art. 5. ${ }^{\circ}$, XXIII); a proibição de imposição de pena de trabalhos forçados e cruéis (art. 5. ${ }^{\circ}$, XLVI); a proibição de prisão civil por dívida (art. 5. ${ }^{\circ}$, LXVII).$^{73}$

72 SENTO-SÉ, Jairo Lins de Albuquerque. Trabalho escravo no Brasil. São Paulo: LTr, 2001. p. 59.

73 SANTOS, Ronaldo Lima dos. A escravidão por dívidas nas relações de trabalho no Brasil contemporâneo. Revista do Ministério Público do Trabalho, São Paulo: LTr, ano XIII, n. 26, p. 62, 2003. 
E a prática da escravidão por dívida é combatida no Direito Internacional do Trabalho, conforme preceitua o artigo $7 .^{\circ}$, itens 1 e 2 , da Convenção n. ${ }^{\circ} 95$ da OIT. ${ }^{74}$

Quando se fala no trabalho escravo no Brasil, é comum associar tal exploração com regiões longínquas do País. No entanto, aos domingos milhares de bolivianos reúnemse para matar as saudades da terra natal, em uma praça chamada Kantuta (ou Padre Bento), que fica no bairro do Pari, a menos de dez quilômetros da Praça da Sé - marco zero da cidade de São Paulo, capital do Estado mais desenvolvido do País e o maior centro financeiro da América Latina -, e é hoje um dos maiores entrepostos de trabalho escravo no mundo. Segundo estimativas da Organização das Nações Unidas (ONU), 700 mil pessoas são traficadas anualmente, e o mercado clandestino de trabalhadores é a terceira principal atividade criminosa no mundo, movimentando US\$ 12 bilhões/ano, atrás apenas dos tráficos de drogas e de armas. Com o crescimento do desemprego e a globalização da miséria, especialmente a partir da última década do século passado, a expectativa é que o tráfico de armas seja rapidamente ultrapassado pelo tráfico de trabalho escravo. ${ }^{75}$

$\mathrm{Na}$ Capital, os latino-americanos ilegais, principalmente bolivianos, trabalham em situação degradante, em oficinas de costuras ilegais, geralmente para outros estrangeiros, em porões e locais fechados, em cômodos apertados, divididos por paredes de compensados para não se relacionarem com outros trabalhadores. Os locais não têm higiene e as refeições são descontadas do salário a receber, assim como outras despesas básicas com água, luz e moradia. Os patrões retêm seus documentos e ameaçam entregálos à polícia federal.

Aqui, além da exploração do trabalho forçado, temos o problema da ilegalidade da imigração. O Estatuto do Estrangeiro não autoriza a atividade para o estrangeiro com visto de turista, de trânsito ou temporário. Os ilegais não podem exercer atividade remunerada.

\footnotetext{
74 “Art. 7. ${ }^{\circ}-1$. Quando em uma empresa forem instaladas lojas para vender mercadorias aos trabalhadores ou serviços a ela ligados e destinados a fazer-lhes fornecimentos, nenhuma pressão será exercida sobre os trabalhadores interessados para que eles façam uso dessas lojas ou serviços.

2. Quando o acesso a outras lojas ou serviços não for possível, a autoridade competente tomará medidas apropriadas no sentido de obter que as mercadorias sejam fornecidas a preços justos e razoáveis, ou que as obras ou serviços estabelecidos pelo empregador não sejam explorados com fins lucrativos, mas sim no interesse dos trabalhadores."

75 FON, Antonio Carlos. Trabalho escravo. Crônicas da infâmia. Revista da CUT, São Paulo, ano I, n. 2, p. 6-9, mar. 2004.
} 
Então, quando libertos, não recebem qualquer direito trabalhista e não podem fazer reivindicações. Para buscar solução para todos os embaraços encontrados, o Ministério Público do Trabalho da 2. ${ }^{\text {a }}$ Região - PRT-2, após discussões realizadas, propôs criar um grupo de estudos para viabilizar juridicamente a possibilidade de concessão de autorização de trabalho e visto aos trabalhadores estrangeiros em situação irregular que denunciarem/testemunharem o trabalho escravo. ${ }^{76}$

Com a abolição formal da escravidão em 1988, a abolição do instituto jurídico vai sendo consolidada no século XX.

O Brasil é signatário dos seguintes tratados e convenções internacionais, no sentido de proibir, em todas as suas formas, a escravidão e o tráfico de escravos: a) Declaração Universal dos Direitos do Homem, Nações Unidas, 1948; b) Convenção das Nações Unidas sobre Escravatura, 1926, emendada pelo Protocolo de 1953 e Convenção Suplementar sobre a Abolição da Escravatura, de 1956; c) Convenção n. 29 da OIT, ratificada pelo Brasil em 1957, com vigência no território nacional em $1958 ;{ }^{77}$ d) Convenção n. ${ }^{\circ} 105$ da OIT, de 1957, com vigência nacional de 1966 - sobre a Abolição do Trabalho Forçado; e) Declaração Sociolaboral do Mercosul, de 1998, que prevê no seu artigo $5^{\circ}$ o compromisso dos países signatários com a eliminação do trabalho forçado.

Na legislação trabalhista, a escravidão é coibida pela Consolidação das Leis do Trabalho (CLT), em diversos dispositivos, como pela ausência de registro em carteira de trabalho, com violação aos dispositivos da CLT: artigo 41, caput; artigos 13 e 29, caput.

$\mathrm{Na}$ área da segurança e higiene do trabalhador rural, usualmente são constatados descumprimentos ao preceito contido no inciso XXII do artigo 7. ${ }^{\circ}$ da Constituição Federal, às disposições contidas no Capítulo $\mathrm{V}$ da CLT, artigos 154 e seguintes, bem como às Normas Regulamentadoras da Portaria n. ${ }^{\circ} 3.214 / 78$ do MTE. É comum não haver fornecimento de água potável; as condições de moradia são precárias, sem as mínimas

76 MENDES, Almara Nogueira. Nova forma de escravidão urbana: trabalho de imigrantes. Revista do Ministério Público do Trabalho, ano XIII, n. 26, p. 69-70, set. 2003.

77 Trata-se do primeiro instrumento normativo a conceituar "trabalho forçado ou obrigatório", como aquele que é "exigido de um indivíduo sob ameaça de qualquer penalidade e para o qual ele não se ofereceu de espontânea vontade" (art. 2. ${ }^{\circ}$ ). 
condições de higiene; muitas vezes é fornecida alimentação deteriorada. E, no que tange à jornada de trabalho cumprida pelo trabalhador escravizado, há total desrespeito quanto à limitação das 8 horas diárias e 44 horas semanais, determinada pelo artigo 7. ${ }^{\circ}, \mathrm{XIII}, \mathrm{CF}$.

A coibição ao trabalho escravo também é prevista na legislação ordinária penal, como na Lei n. ${ }^{\circ}$ 9.777, de 29.12.1998, que alterou o Código Penal e estabelece coibições à exploração do trabalho forçado, bem como em várias instruções normativas, decretos e portarias. $^{78}$

Saliente-se que o escravo não possui o corpo como livre instrumento de sua vontade; expropriado dos meios de produção, não é livre, proprietário natural de si mesmo para vender sua força em troca de salário. No modo de produção capitalista, a propriedade de si mesmo é um atributo que impede os trabalhadores de se tornarem escravos. No escravismo, a expropriação torna o trabalhador escravo; no modo capitalista, torna-o "livre". 79

\subsubsection{O trabalho na sociedade atual}

Abolida a escravidão nos Estados Unidos, inicia-se o processo de industrialização, e diante da concentração de renda nas mãos de poucos empresários do Norte, desenvolvese com a formação de trusts, união de diversas empresas em um empreendimento comum; a produção fica sob controle de poucas grandes empresas. Essa união dá ensejo a uma produção racional, organizada, sendo um dos expoentes Rockefeller, que se afasta do controle das companhias das estradas de ferro, criando uma rede de dutos que cobre todo o território americano, permitindo-lhe controlar quase toda a indústria do petróleo. ${ }^{80}$

Em paralelo, a Europa teve péssimas colheitas, os preços agrícolas subiram muito, a situação das camadas mais pobres da população piorou. $\mathrm{O}$ empobrecimento dos trabalhadores provocou a queda no consumo de tecidos; as fábricas pararam, dispensaram

78 LOTTO, Luciana Aparecida. Ação civil pública trabalhista contra o trabalho escravo no Brasil. São Paulo: LTr, 2008. p. 70-73.

79 SIMÕES, Carlos Jorge Martins. Direito do trabalho e modo de produção capitalista. São Paulo: Símbolo, 1979. p. 121.

${ }^{80}$ SOUTO MAIOR, Jorge Luiz. Curso de direito do trabalho: teoria geral do direito do trabalho. São Paulo: LTr, 2011. v. 1, Parte I, p. 189-190. 
operários. Os salários foram reduzidos e os preços dos alimentos dispararam. Em algumas regiões, como na França e na Inglaterra, a crise era principalmente industrial, enquanto na Itália e na Irlanda era predominantemente agrária. A situação provoca início de movimentos reivindicatórios, no fundo, socialistas; no entanto, não havia um movimento organizado; a liderança da oposição ao governo coube então aos liberais e nacionalistas. ${ }^{81}$

Eclode a Revolução de 1848, um movimento social inédito na história. Explica Hobsbawm que a revolução que eclodiu nos primeiros meses de 1848 foi, no sentido liberal, o insurgimento dos trabalhadores pobres nas cidades - especialmente nas capitais da Europa Ocidental e Central; foi um movimento motivado pelo estado de miséria, sustenta Hobsbawm. Ressalta esse autor que não concorda com alguns historiadores, que entendem que a Revolução de 1848 não se insere no contexto de uma luta da classe operária.

Relata que até então nunca houve um movimento que tivesse se espalhado tão rápida e amplamente, alastrando-se sobre fronteiras e países. Afirma que foi a primeira revolução potencialmente global, cuja influência pode ser detectada na insurreição de 1848 em Pernambuco, no Brasil e, poucos anos depois na Colômbia. Ressalta o autor que, em certo sentido, foi o paradigma de um tipo de "revolução mundial", 82

Tal movimento, no entanto, sem organização consolidada, foi vencido. E, ainda que a influência do Manifesto Comunista sobre a Revolução de 1848 não tenha sido direta, pois publicado somente na Alemanha e na França, inegável que as ideias nele contidas e já difundidas junto ao movimento operário constituíram impulso para a ação.

Com a derrota da Revolução de 1848, os ânimos quanto à possibilidade de alteração da realidade por meio de um movimento social foram arrefecidos. A partir de 1851 e até o início da década de 1870 o mundo passa por um crescimento econômico; salienta Hobsbawm que foi nesse período que o mundo se tornou capitalista e uma minoria de países desenvolvidos transformou-se em economias industriais. Tal expansão ocorreu com a chegada da estrada de ferro, do vapor e do telégrafo, que ampliaram o espaço

\footnotetext{
${ }^{81}$ SOUTO MAIOR, Jorge Luiz. Curso de direito do trabalho: teoria geral do direito do trabalho. São Paulo: LTr, 2011. v. 1, Parte I, p. 176.

${ }^{82}$ HOBSBAWM, Eric. A era do capital: 1848-1875. São Paulo: Paz e Terra, 2012. p. 32-33.
} 
geográfico do capitalismo, que agora tinha o mundo inteiro ao seu dispor; esse autor destaca que entre 1850 e 1870 o comércio mundial cresceu $260 \%{ }^{83}$

As pessoas atribuíam à liberdade da iniciativa privada o fator desencadeador do sucesso econômico. O liberalismo econômico era a receita para o crescimento e, à época, tal pensamento era consenso entre economistas, políticos e administradores, o que propiciou a exacerbação da lógica da livre negociação.

Algumas leis já haviam sido implementadas, a partir da segunda metade do século XIX, estabelecendo limites na relação capital-trabalho. Exemplo disso é a pioneira legislação do trabalho britânica, com o Factory Act (1833 e 1844), o Coal Mining Act (1842) e o Ten Hours Act (1847), que indica o caráter protecionista que passa a orientar a evolução legislativa subsequente em todos os países capitalistas, constituindo o primeiro núcleo específico e característico do ideário protecionista do direito do trabalho. ${ }^{84}$

Elenca Jorge Souto Maior que em 1850, também na Inglaterra, é editada lei, seguida por outra de 1853, que estabelece a jornada legal entre seis da manhã e seis da noite, para mulheres e crianças que trabalhem nas indústrias sujeitas a regulamentação; em 1867 essa proteção é estendida a crianças e mulheres que laborem em indústrias que possuam motor mecânico. Em 1864, na França, inicia-se uma tendência de tolerância quanto aos movimentos operários, por intermédio de uma lei que proclama a liberdade de coalizão.

Em 1871 o Trade Union Act reconhece como legais as associações profissionais; no entanto, Leis de 1876 e 1913 preveem que as associações podem obter personalidade jurídica mediante registro; quando tais entidades efetuavam o registro, caíam sob um controle permanente dos seus Estatutos, movimentação social e patrimônio. As primeiras notícias sobre a adoção de férias para os trabalhadores da indústria remontam ao ano de $1872 .^{85}$

${ }^{83}$ HOBSBAWM, Eric. A era do capital: 1848-1875. São Paulo: Paz e Terra, 2012. p. 60.

${ }^{84}$ FREITAS JR., Antonio Rodrigues de. Tópicos da agenda protecionista na nova Constituição brasileira. Revista Jurídica do Trabalho, ano II, n. 5, p. 107-108, abr.-jun. 1989.

${ }^{85}$ SOUTO MAIOR, Jorge Luiz. Curso de direito do trabalho: teoria geral do direito do trabalho. São Paulo: LTr, 2011. v. 1, Parte I, p. 193-194. 
Em 1875 foi editado o Conspiracy and Protection of Property Act, estabelecendo que todo acordo entre duas ou mais pessoas, para provocar ou sustentar litígio entre patrões e trabalhadores, não podia ser punido pelo fato de constituir coalizão; passam a ser castigados com multa e arresto os atentados contra a liberdade do trabalho, inclusive a perseguição utilizada pelos trabalhadores em greve para obrigar o companheiro de trabalho a aderir ao movimento contra sua vontade. ${ }^{86}$

O Factory and Workshop Act, de 1878, ratifica todas as leis precedentes referentes ao trabalho infantil e da mulher e contém novas disposições a respeito da utilização dessa mão de obra no trabalho perigoso ou insalubre. ${ }^{87}$

Em 1893, na França, é editada a primeira lei sobre segurança e higiene do trabalho, e em 1898 entra em vigor a lei sobre a responsabilidade patronal por acidente do trabalho. Em 1897, na Inglaterra, é aprovada a lei de acidentes do trabalho.

Desde a derrota da Revolução de 1848, com a prevalência do ideário do liberalismo econômico, algumas leis foram modificadas; estabeleceu-se igualdade de tratamento entre patrão e empregado, no rompimento do contrato; o vínculo anual dos mineiros na Inglaterra foi abolido.

Nessa fase de desenvolvimento do capitalismo industrial, as empresas eram essencialmente familiares; não era a autoridade impessoal da "companhia" que dirigia os negócios; a empresa era identificada com um único homem.

A situação desfavorável dos trabalhadores era alimentada pela esperança de ganhar o suficiente para entrar no mundo burguês, explicita Hobsbawm, dizendo que na França, Inglaterra e Alemanha prevalecia a ideia de que o

[...] máximo adequado para a classe trabalhadora era uma quantidade suficiente de comida boa e decente (preferivelmente sem muita bebida), uma habitação modesta e lotada, vestimenta adequada para proteger a

\footnotetext{
${ }^{86}$ SOUTO MAIOR, Jorge Luiz. Curso de direito do trabalho: teoria geral do direito do trabalho. São Paulo: LTr, 2011. v. 1, Parte I, p. 194.

87 Idem, ibidem.
} 
moral, a saúde e o conforto, sem arriscar uma tendência à imitação dos superiores em escala social. ${ }^{88}$

De 1760 até por volta de 1850, a Revolução Industrial se restringe à Inglaterra, chamada a "oficina do mundo". Preponderam a produção de bens de consumo, especialmente têxteis, e a energia a vapor. A partir de 1850, a Revolução espalha-se pela Europa, América e Ásia: Bélgica, França, Alemanha, Estados Unidos, Itália, Japão, Rússia. Cresce a concorrência, a indústria de bens de produção se desenvolve, as ferrovias se expandem; surgem novas formas de energia, como a hidrelétrica e a derivada do petróleo. O transporte também se revoluciona com a invenção da locomotiva e do barco a vapor.

Como alerta Jorge Souto Maior, na segunda metade do século XIX, é relevante o relato das condições de trabalho existentes na indústria, que demonstra que nenhum avanço considerável se produziu no modelo liberal capaz de solucionar os problemas gerados pelo modelo de produção capitalista. Diz o autor que da formação e expansão do capitalismo, que perdura por mais de cem anos, não há distinção notável, uma vez que a imagem de uma fábrica na França ou nos EUA no início do século XX não difere muito de outra na Inglaterra no fim do século XVIII, podendo-se dizer o mesmo das minas de carvão. ${ }^{89}$

As más condições de vida e de trabalho chegam a um nível de gravidade que a Igreja, que legitima a ordem liberal, chama a atenção para a questão social, com a publicação da Carta Encíclica Rerum Novarum, pelo Papa Leão XIII, em 1891, sobre a condição dos operários. A Igreja procura afastar os fiéis dos movimentos revolucionários de cunho socialista; apela para que o homem aceite com paciência a sua condição, enquanto conclama aos ricos e aos patrões para que não tratem o operário como escravo,

${ }^{88}$ HOBSBAWM, Eric. A era do capital: 1848-1875. São Paulo: Paz e Terra, 2012. p. 332.

${ }^{89}$ SOUTO MAIOR, Jorge Luiz. Curso de direito do trabalho: teoria geral do direito do trabalho. São Paulo: LTr, 2011. v. 1, Parte I, p. 223. A esse respeito, ilustre-se com a obra Germinal, de Émile Zola, escrita em 1885, que é universalmente considerada a obra-prima do autor. Ao longo de Germinal, com descrição das condições de vida subumanas em uma comunidade de mineiros, Zola começou a destacar os elementos de opressão social, as primeiras lutas do movimento operário moderno e as influências causadas pela Primeira Internacional, associação criada por Karl Marx em 1864 para reunir os trabalhadores do mundo. Enfocando os operários das minas de carvão do Norte da França, o autor denuncia as péssimas condições de trabalho e mostra o início da luta de classes entre proletariado e burguesia (ZOLA, Émile. Germinal. São Paulo: Companhia das Letras, 2000). 
respeitem a dignidade humana e não imponham aos operários trabalhos superiores às suas forças. ${ }^{90}$

A exacerbação dos ideais liberais, após a repressão vitoriosa ao movimento revolucionário de 1848 e do sucesso econômico vivenciado a partir de 1851, era fator que propiciava a persistência das más condições de trabalho. O capitalismo industrial desenvolve-se de início na Inglaterra, se espalha pela Europa e chega aos Estados Unidos, onde uma série de repressões a movimentos operários, iniciada em $1 .^{\circ}$ de maio de 1886 , deixou mais de oitenta trabalhadores mortos; fato e data tornaram-se símbolos na luta trabalhista, lembra Souto Maior. ${ }^{91}$

Surge o capitalismo industrial monopolista e essa mudança, que ocorre a partir do início da década de 1870, após enorme crise econômica, eliminou pequenas empresas e fortaleceu corporações, permitindo investimento em novas tecnologias.

\section{Como explica Hobsbawm,}

90 “[...] O primeiro princípio é que o homem deve aceitar com paciência a sua condição: é impossível que na sociedade civil todos sejam elevados ao mesmo nível. É, sem dúvida, isto o que desejam os socialistas; mas contra a natureza, todos os esforços são vãos. Foi ela, realmente, que estabeleceu entre os homens diferenças tão múltiplas como profundas; diferenças de inteligência, de talento, de habilidade, de saúde, de força; diferenças necessárias, de onde nasce espontaneamente a desigualdade das condições. Esta desigualdade, por outro lado, reverte em proveito de todos, tanto da sociedade como dos indivíduos; porque a vida social requer um organismo muito variado e funções muito diversas, e o que leva precisamente os homens a partilharem estas funções é, principalmente, a diferença de suas respectivas condições. Pelo que diz respeito ao trabalho em particular, o homem, mesmo no estado de inocência, não era destinado a viver na ociosidade, mas, ao que a vontade teria abraçado livremente como exercício agradável, a necessidade lhe acrescentou, depois do pecado, o sentimento da dor e o impôs como uma expiação: 'A terra será maldita por tua causa; é pelo trabalho que tirarás com que alimentar-te todos os dias da vida' (Gen 3, 17).

[...] Quanto aos ricos e aos patrões, não devem tratar o operário como escravo, mas respeitar nele a dignidade do homem, realçada ainda pela do cristão. O trabalho do corpo, pelo testemunho comum da razão e da filosofia cristã, longe de ser um objeto de vergonha, faz honra ao homem, porque lhe fornece um nobre meio de sustentar a sua vida. O que é vergonhoso e desumano e usar dos homens como de vis instrumentos de lucro, e não os estimar senão na proporção do vigor dos seus braços. $\mathrm{O}$ cristianismo, além disso, prescreve que se tenham em consideração os interesses espirituais do operário e o bem da sua alma. Aos patrões compete velar para que a isto seja dada plena satisfação, que o operário, não seja entregue à sedução e às solicitações corruptoras, que nada venha enfraquecer o espírito de família, nem os hábitos de economia. Proíbe também aos patrões que imponham aos seus subordinados um trabalho superior às suas forças ou em desarmonia com a sua idade ou o seu sexo. [...]." Disponível em: $<$ http://www.cpihts.com/PDF/Enc\%C3\%ADclica\%20Rerum\%20Novarum.pdf>. Acesso em: 21 set. 2012.

${ }^{91}$ SOUTO MAIOR, Jorge Luiz. Curso de direito do trabalho: teoria geral do direito do trabalho. São Paulo: LTr, 2011. v. 1, Parte I, p. 223. 
A economia capitalista mudou de quatro formas significativas. Em primeiro lugar, entramos agora numa nova era tecnológica, não mais determinada pelas invenções e métodos da primeira Revolução Industrial: uma era de novas fontes de poder (eletricidade e petróleo, turbinas e motor a explosão), de nova maquinaria a partir de novos materiais (ferro, ligas, metais não ferrosos), de indústrias baseadas em novas ciências tais como a indústria em expansão da química orgânica. ${ }^{92}$

Descobertas tecnológicas no início do século XX foram responsáveis por importantes modificações na organização do trabalho e da produção, enquanto vai se erigindo a construção do direito do trabalho protetor, destaca Otavio Pinto Silva. ${ }^{93}$

Surgem novas formas de energia, como a hidrelétrica e a derivada do petróleo, que vieram substituir o vapor e o carvão, impulsionando o processo de industrialização e alterando as formas de utilização do trabalho humano, diz esse autor.

Aqui merecem destaque a obra de Frederick Winslow Taylor e a teoria da administração científica, indispensável para entender uma das componentes da matriz ideológica do movimento de racionalização industrial das primeiras décadas do século.

A "Administração Científica" propôs a divisão do processo produtivo em operações elementares, correspondentes a movimentos rápidos e repetitivos, executados com máquinas padronizadas; marcou as técnicas de organização e gestão do trabalho e da produção, como se evidencia ao examinarmos os manuais de engenharia de produção, de ergonomia e de psicologia industrial, todos permeados pela ideologia taylorista, traduzida pelos seus princípios ou pelos seus pressupostos. ${ }^{94}$

As últimas décadas do século XX trouxeram um desenvolvimento tecnológico nunca antes experimentado; há crescente e veloz automação, e espetacular evolução da atividade econômica.

Trata-se, diz Otavio Pinto e Silva, da chamada

${ }^{92}$ HOBSBAWM, Eric J. A era do capital, 1848-1875. São Paulo : Paz e Terra, 2012, p. 454.

93 SILVA, Otavio Pinto e. Subordinação, autonomia e parassubordinação nas relações do trabalho. São Paulo: LTr, 2004. p. 112.

${ }^{94}$ FLEURY, Afonso Carlos Correia; VARGAS, Nilton et al. Organização do trabalho: uma abordagem interdisciplinar: sete casos brasileiros para estudo. São Paulo: Atlas, 1983. p. 17. 
[...] "Terceira Revolução Industrial”, ou "Revolução Tecnológica", iniciada logo após a Segunda Guerra Mundial e caracterizada, conforme as palavras de Jeremy Rifkin, pela invasão da última esfera humana - os domínios da mente - por robôs, computadores e "softwares". ${ }^{95}$

As "máquinas inteligentes" são programadas e passam a realizar desde tarefas mais simples até as de maior complexidade, em velocidade não alcançada pelo homem que as programou, e que passa a ser substituído por elas. Assim, como ilustra Otavio Pinto $e$ Silva, as máquinas são capazes de realizar funções conceituais, gerenciais, administrativas e de coordenar todo o fluxo da produção, desde a extração da matéria-prima, ao marketing e à distribuição do produto final.

Nesse contexto, verifica-se uma desproletarização do trabalho industrial, fabril, principalmente nos países de capitalismo avançado; em outras palavras, diz Ricardo Antunes, houve uma diminuição da classe operária industrial tradicional. E paralelamente, efetivou-se uma expansão do trabalho assalariado, com ampliação do trabalho assalariado no setor de serviços, heterogeneização do trabalho e crescente participação do contingente feminino. $^{96}$

Prossegue Ricardo Antunes:

[...] vivencia-se também uma subproletarização intensificada, presente na expansão do trabalho parcial, temporário, precário, subcontratado, "terceirizado", que marca a sociedade dual no capitalismo avançado, da qual os gastarbeiters na Alemanha e o lavoro nero na Itália são exemplos do enorme contingente de trabalho imigrante que se dirige para o chamado Primeiro Mundo, em busca do que ainda permanece do welfare state, invertendo o fluxo migratório de décadas anteriores, que era do centro para a periferia.

O mais brutal resultado dessas transformações é a expansão, sem precedentes na era moderna, do desemprego estrutural, que atinge o mundo em escala global. Pode-se dizer, de maneira sintética, que há uma processualidade contraditória que, de um lado, reduz o operariado industrial e fabril; de outro, aumenta o subproletariado, o trabalho precário e o assalariamento no setor de serviços. Incorpora o trabalho feminino e exclui os mais jovens e os mais velhos. Há, portanto, um

95 SILVA, Otavio Pinto e. Subordinação, autonomia e parassubordinação nas relações do trabalho. São Paulo: LTr, 2004. p. 111.

96 ANTUNES, Ricardo. Adeus ao trabalho?: ensaio sobre as metamorfoses e a centralidade do mundo do trabalho. São Paulo: Cortez, 2010. p. 47. 
processo de maior heterogeneização, fragmentação e complexificação da classe trabalhadora $\left[\ldots . .{ }^{97}\right.$

Impõe-se a tarefa de examinarmos, nesse mundo do trabalho em constante transformação, ou, como diz Ricardo Antunes, em constante metamorfose, como se dá o processo de organização do trabalho atual, bem como os desafios infligidos aos trabalhadores.

\subsubsection{O trabalhador e o processo de organização do trabalho}

Como mencionado no primeiro tópico deste capítulo, em que tratamos da sua conceituação, a palavra "trabalho" engloba várias realidades, perpassa por diversas disciplinas do conhecimento. Trabalho é um termo que também pode ser utilizado para designar condições de trabalho: trabalho penoso, trabalho exaustivo, trabalho pesado; pode equivaler ao resultado de um trabalho: trabalho malfeito, trabalho primoroso, trabalho perfeito; ou a própria atividade de trabalho: fazer seu trabalho, trabalho meticuloso. Tais expressões podem designar qualquer uma das três realidades, o que demonstra que atividade, as condições de sua realização e o seu resultado não existem independentemente uns dos outros, e o trabalho é a unidade dessas três realidades. ${ }^{98}$

Guèrin e outros pesquisadores enfocam o trabalho na obra elaborada com base na prática da ergonomia, e dizem que os ergonomistas, especialmente os que se baseiam na escola franco-belga, afirmam que a atividade de trabalho é o cerne de seu interesse. Os autores salientam que as condições de trabalho devem ser examinadas, no entanto para eles é impossível atuar nesse domínio sem considerar o funcionamento global da empresa e suas escolhas em todas as áreas, técnicas, organizacionais, comerciais e sociais. ${ }^{99}$

Prosseguem esclarecendo que a rigor uma análise do trabalho corresponde a uma verificação do sistema e do seu funcionamento; as diferentes realidades que o compõem não deveriam ser separadas, e o analista do trabalho deve ter a competência necessária para

\footnotetext{
97 ANTUNES, Ricardo. Adeus ao trabalho?: ensaio sobre as metamorfoses e a centralidade do mundo do trabalho. São Paulo: Cortez, 2010. p. 47.

98 GUÈRIN, F. et al. Compreender o trabalho para transformá-lo: a prática da ergonomia. São Paulo: Blücher: Fundação Vanzolini, 2010. p. 11.

99 Idem, ibidem, p. 10.
} 
abordar todas elas. Contudo, na prática, isso não se afigura possível, em função da amplitude do campo teórico e prático a ser examinado. Assim, as realidades que compõem o trabalho são consideradas separadamente nas práticas das empresas: o departamento de recursos humanos preocupa-se com o desequilíbrio da pirâmide etária dos empregados, com a necessidade ou não de deslocar trabalhadores, prioriza os que estão em atividade; analisa capacidades, aptidões, mobilidade, etc. Os departamentos comerciais e de qualidade, pressionados pela concorrência, analisam, ainda que com foco diferente, os resultados obtidos e a relação qualidade/preço; o serviço de segurança e medicina do trabalho preocupa-se com o aumento do número de acidentes, atua quanto às condições técnicas e organizacionais da produção, o que evidencia que o trabalho em uma mesma empresa é objeto de abordagens diferenciadas. ${ }^{100}$

Quando se pedem informações acerca do trabalho em uma empresa, a primeira resposta da direção é focada na atividade, o que também ocorre quando é o trabalhador que fala sobre a empresa onde trabalha. No enfoque da empresa, a atividade corresponde aos resultados e aos objetivos propostos, se foram ou não atingidos; trata-se, nesse caso, do resultado da atividade coletiva de trabalho. ${ }^{101}$

Para o desenvolvimento de uma ação ergonômica, é preciso que haja diálogo com os trabalhadores dos mais diversos setores; esses interlocutores falarão sobre os meios que a empresa dispõe para a obtenção dos resultados. A ênfase será alterada quanto a um ou outro meio, dependendo do interlocutor, mas, no mais das vezes, são os meios materiais e financeiros que são lembrados: número de estabelecimentos, filiais, faturamento, área construída, capacidade de produção etc. Dessa forma, a importância dos recursos humanos e da organização limita-se somente ao "potencial de ação a serviço dos resultados esperados". ${ }^{102}$

E, quando os trabalhadores descrevem espontaneamente o seu trabalho e de colegas, a tendência é informar os resultados a serem obtidos, como: "A" embala produtos", "B" costura vestidos, "C" dirige trens; e em seguida descrevem os meios que

\footnotetext{
${ }^{100}$ GUÈRIN, F. et al. Compreender o trabalho para transformá-lo: a prática da ergonomia. São Paulo: Blücher: Fundação Vanzolini, 2010. p. 11.

${ }^{101}$ Idem, ibidem, p. 13.

${ }^{102} \mathrm{Idem}$.
} 
usam; elencam equipamentos, maquinário e materiais: como a máquina de costura utilizada; o computador; o telefone etc. - a fala espontânea não revela o que é o trabalho em si, e sim o que é uma tarefa: "é um resultado antecipado, fixado dentro de condições determinadas". 103

Ensinam os autores citados que a tarefa mantém uma relação estreita com o trabalho, por meio das condições e dos resultados deste. Fica faltando a atividade de trabalho, isto é, como os resultados são obtidos e quais os meios utilizados. Dizem que é preciso distinguir três realidades:

- a tarefa como resultado antecipado fixado em condições determinadas;

- a atividade de trabalho como realização da tarefa;

- o trabalho como unidade da atividade de trabalho, das condições reais e dos resultados efetivos dessa atividade. ${ }^{104}$

A análise do trabalho é o exame do conjunto do sistema, em que está incluída a atividade. Existem outras maneiras de se analisar o trabalho; algumas não incluem a análise da atividade; nesse caso, limita-se à análise do trabalho prescrito. E a análise da atividade que não engloba a análise do trabalho não consegue vislumbrar possibilidades de transformação, pois não considera o que determina, constrange e ao mesmo tempo autoriza a atividade concreta do trabalhador.

A análise ergonômica do trabalho é uma análise da atividade, em confronto com o exame dos demais elementos do trabalho.

A atividade de trabalho não pode ser reduzida à prescrição de tarefas e é distinta a atividade humana. Assim, exemplificando, uma mulher que não tem atividade remunerada declara-se sem profissão; no entanto, isso não significa que não se ativa, ao contrário, "trabalha" e muito, sem paga; o mesmo pode se dizer do estudante que nunca trabalhou ou

\footnotetext{
${ }^{103}$ GUÈRIN, F. et al. Compreender o trabalho para transformá-lo: a prática da ergonomia. São Paulo: Blücher: Fundação Vanzolini, 2010. p. 14.

${ }^{104}$ Idem, ibidem, p. 15.
} 
do aposentado que parou de trabalhar. Tanto o estudante como a dona de casa e o aposentado têm atividade. Contudo, não é a atividade em si, e sim sua finalidade, que caracteriza o trabalho.

As análises de situações de trabalho realizadas pela ergonomia da atividade e pela ergologia consideram de modo particular a distância sempre existente entre as prescrições das tarefas a serem realizadas e o trabalho real. Nas ciências da engenharia e da gestão, as diferenças entre os modelos teóricos e a realidade são também reconhecidas, levando normalmente aos aperfeiçoamentos dos modelos de gestão e de controle, que não param de evoluir. Nas abordagens mais recentes, o conceito de variação ou de distância em relação ao real é colocado como princípio de base da melhoria contínua ("Nenhum sistema é perfeito"; "Todo sistema pode ser melhorado"); exemplos nesse sentido são a implementação e a certificação de normas ISO 9000 e a informatização do controle na indústria de processos contínuos. ${ }^{105}$

Saliente-se que o homem, como indivíduo isolado, não tem domínio sobre as condições, nem sobre os resultados de sua atividade profissional; e é nesse sentido que alguns autores definiram o trabalho como atividade imposta, sendo o regime assalariado a forma atual dessa imposição. ${ }^{106}$

O trabalho, com todos os seus componentes já apontados - atividade, condições e resultados da atividade -, apresenta "caráter duplo", pessoal e socioeconômico, conforme o ângulo que se examine, o da pessoa que trabalha ou o da empresa.

A dimensão pessoal se expressa nas estratégias usadas pelos trabalhadores para realizar sua tarefa - e estas são o objeto real da análise ergonômica da atividade: como aquele trabalhador ou aquela trabalhadora faz para atingir os objetivos traçados, as tarefas que lhe foram impostas, e, mesmo em condições determinadas, não de ter uma apropriação

${ }^{105}$ LIMA, Francisco de P. A. Norma e atividade humana: modelos dinâmicos da prescrição e historicidade das situações de trabalho. In: DIEESE/CESIT (Org.). Trabalho e abordagem pluridisciplinar: estudos Brasil, França e Argentina. São Paulo: Dieese e Campinas: CESIT, 2005. p. 51-68.

${ }^{106}$ GUÈRIN, F. et al. Compreender o trabalho para transformá-lo: a prática da ergonomia. São Paulo: Blücher: Fundação Vanzolini, 2010. p. 16. 
pessoal. O resultado de uma atividade é sempre uma "obra" pessoal, sinal da habilidade, da atenção, destreza etc.

E é sempre preciso levar em consideração que para o homem sua atividade, quando concretizada em um resultado, impregna de sentido sua relação com o mundo; assim, trabalhar não é somente ganhar a vida, é também desempenhar um papel na sociedade.

Guèrin traça um esquema analisando o trabalho, quanto à experiência na empresa, sob o enfoque na pessoa no trabalho, as condições pessoais são: apropriação, estruturação, gestão etc.; sob o foco do trabalho, trata-se das condições de trabalho.

Quanto à história, experiência profissional, vida pessoal, as características pessoais são: idade, tempo de casa, formação, estado de saúde, itinerário etc.; para o enfoque socioeconômico aqui se encontra a atividade de trabalho.

E para a significação, socialização, personalização, a obra pessoal é acabamento, habilidade, personalidade, recepção etc.; sob o foco no trabalho, trata-se dos resultados. ${ }^{107}$

Explicam os autores que a compreensão da atividade de trabalho somente é possível em situação real; é preciso atentar para o que o operário faz concretamente, o que também ocorre com as condições de trabalho, são sempre as condições da atividade pessoal. E, quando os trabalhadores se expressam, falando em "sua" máquina ou "suas" ferramentas, não se trata de sentimento de propriedade; trata-se de atividade, e para trabalhar é necessário estruturar seu "espaço sensorial e motor"; e a relação pessoal da atividade com o resultado procurado é mediada pelas condições espaciais e temporais, relacionais, em que a atividade se desenvolve.

Nessas condições incluem-se o próprio trabalhador e o convívio com seus colegas de trabalho, que constitui um coletivo, que inclusive desempenha importante papel na proteção da saúde e segurança, de todos e de cada um, alerta Edith Seligmann Silva. Esse convívio e a continuidade da comunicação e interação são essenciais para a constituição do

${ }^{107}$ GUÈRIN, F. et al. Compreender o trabalho para transformá-lo: a prática da ergonomia. São Paulo: Blücher: Fundação Vanzolini, 2010. p. 19. 
grupo e para sua manutenção. Dentro desse coletivo são praticados e transmitidos "segredos do ofício", os denominados "macetes", que permitem proteger a saúde e a execução de um trabalho bem-feito, fonte de orgulho para cada integrante do grupo. Seligmann Silva diz que esse coletivo origina uma flexibilização dos modos de fazer, em acordo com as regras do trabalho bem-feito e dos saberes de prudência. É exemplo de flexibilização controlada pelos próprios trabalhadores para possibilitar o trabalho bem-feito e ao mesmo tempo seguro, respeitando os tempos humanos e a integridade dos corpos. ${ }^{108}$

Aqui se pode dizer que a atividade é social em primeiro lugar, como diz Guèrin, pois o que é produzido resulta da atividade coordenada de vários trabalhadores; e aqui está presente o caráter socioeconômico do trabalho. Ilustra com a linha de montagem, que é o sistema de organização que mostra mais claramente a natureza social da atividade, pois a cooperação entre os operadores é imediata. ${ }^{109}$

Essa socialização tomou historicamente a forma de parcelamento de tarefas, o que nos remete ao início do século XX, quando algumas descobertas tecnológicas foram responsáveis por importantes modificações na organização do trabalho e da produção.

E uma obra de particular importância foi a do engenheiro Frederick Winslow Taylor, que formulou e publicou, em 1911, a teoria da "Administração Científica", imprescindível para entender uma das componentes da matriz ideológica do movimento de "racionalização" industrial das primeiras décadas do século.

Em Princípios de administração científica, Taylor identificava o desconhecimento por parte da administração empresarial de como realizar o trabalho como a raiz dos problemas de controle; preocupação mais associada ao controle do ritmo de trabalho e à sua intensificação do que propriamente à apropriação do saber operário, apesar de sua obra propalar o oposto; interessava, assim, identificar qual a possibilidade de aumentar a extração do excedente econômico. O primeiro princípio taylorista propõe a interferência e disciplina do conhecimento operário sob o comando da gerência.

\footnotetext{
${ }^{108}$ SILVA, Edith Seligmann. Trabalho e desgaste mental: o direito de ser dono de si mesmo. São Paulo: Cortez, 2011. p. 314.

${ }^{109}$ GUÈRIN, F. et al. Compreender o trabalho para transformá-lo: a prática da ergonomia. São Paulo: Blücher: Fundação Vanzolini, 2010. p. 20.
} 
Fleury e Vargas explicam uma das técnicas que Taylor divulgava para alcançar os seus objetivos, com a análise científica do trabalho:

[...] Em poucas palavras tratava do estudo do movimento elementar de cada operário, decifrando quais são úteis para eliminar os inúteis, e assim aumentar a intensificação do trabalho. Tal análise era acompanhada do registro dos tempos com o intuito de identificar o "tempo ótimo" para realizar uma tarefa. A gerência passava assim a fixar "cientificamente" um ritmo de trabalho projetado, em lugar de determinar subjetivamente um quantum de trabalho a executar segundo a experiência do próprio trabalhador:

"O estudo de tempos é o elemento da administração científica que torna possível a transferência de habilidade da administração para os operários ... 'Estudo de tempos' consiste em duas categorias gerais, a primeira, a fase analítica, e a segunda, fase construtiva”. [...]

$\mathrm{Na}$ visão de Taylor existia um modo ótimo de realizar o trabalho que com o estudo de tempos e movimentos seria possível alcançar e padronizar.

Do exposto ficaria eliminada a iniciativa operária na escolha do melhor método. Essa função seria da gerência que imporia o método com o respectivo "tempo-padrão" para executá-lo.

Outra ideia subjacente a esses estudos era a identificação do tempo de execução dos movimentos elementares do corpo humano. Com sua catalogação seria possível abandonar o estudo do trabalho concreto e projetar um trabalho "simplificado", ou seja, determinar o tempo de sua duração, sem que este tenha sido executado. [...]. ${ }^{110}$

Explicam tais autores que esse foi o caminho desenvolvido para várias atividades, o que resultou no surgimento de tabelas de tempos elementares predeterminados com o M.T.M. (Methods-Time Measuremen), e, nesse estudo de tempo, Taylor não deixava de considerar a fadiga operária, tendo efetuado várias investigações nesse sentido, para encontrar normas que habilitassem um chefe a conhecer, de antemão, que quantidade de certo trabalho, pesado e contínuo, um homem a ele habituado poderia executar diariamente. A determinação da fadiga diária era essencial, pois poderia prejudicar o ritmo

${ }^{110}$ FLEURY, Afonso Carlos Correia; VARGAS, Nilton et al. Organização do trabalho: uma abordagem interdisciplinar: sete casos brasileiros para estudo. São Paulo: Atlas, 1983. p. 19-21. 
de trabalho. No entanto, a fadiga acumulada por anos de atividade e camuflada pela rotatividade nos empregos, não era objeto de estudo. ${ }^{111}$

O segundo princípio taylorista tratava da seleção e treinamento; se o trabalho foi dominado pela gerência, o trabalhador adequado pode ser escolhido com maior facilidade, pois o que se procura não é um homem que conheça um ofício ou que tenha várias habilidades. Taylor ilustrava a chamada "seleção científica", com a escolha por determinado tipo de "um homem do tipo bovino", "espécime difícil de encontrar e assim, muito valorizado"; a seleção não consistia em encontrar homens extraordinários, e, sim, em escolher entre homens comuns os apropriados para o tipo de trabalho em vista. ${ }^{112}$

O terceiro princípio segundo a ótica de Taylor era propor à gerência $\mathrm{o}$ planejamento e o controle do trabalho; não concordava com o sistema de administração de sua época, que deixava a um operário antigo a responsabilidade pela administração; defendeu a existência de especialistas responsáveis por cada uma das funções produtivas.

Antonio Rodrigues de Freitas Jr. reporta-se ao modelo taylorista de organização do trabalho, demonstrando como a intensificação do ritmo de produção propicia a fadiga, fator que também caracteriza o trabalho como penoso:

Focalizando o trabalho penoso sob o ponto de vista da fadiga, seja motora (objetiva) ou mental (subjetiva), há como registrar um extraordinário terreno reservado ao exame das limitações que se devem impor ao emprego da força física e da atenção.

Não constitui novidade observar que o modelo taylorista de organização do trabalho (vulgarizado sob o nome de organização "científica"), objetivando a intensificação por padrões ótimos da produtividade, radicou na experiência empresarial deste século o largo emprego de métodos quantificadores e sistematizadores do trabalho humano. A cronoanálise, por exemplo, é em grande parte tributária do pensamento taylorista. Com efeito, o aperfeiçoamento das técnicas produtivas, maximizando a relação produtividade-tempo em situações de limite, na perspectiva taylorista, deu origem a inúmeras manifestações atípicas dos efeitos patológicos da fadiga, tanto da fadiga objetiva (mensurável em calorias gastas na execução do trabalho) quanto da fadiga subjetiva (o chamado stress). ${ }^{113}$

\footnotetext{
${ }^{111}$ FLEURY, Afonso Carlos Correia; VARGAS, Nilton et al. Organização do trabalho: uma abordagem interdisciplinar: sete casos brasileiros para estudo. São Paulo: Atlas, 1983. p. 21.

${ }^{112}$ Idem, ibidem.

${ }^{113}$ FREITAS JR., Antonio Rodrigues de. Tópicos da agenda protecionista na nova Constituição brasileira. Revista Jurídica do Trabalho, ano II, n. 5, p. 115, abr.-jun. 1989.
} 
Para Taylor, o elemento central da programação do trabalho é a "tarefa" ou a “ordem de produção”. É importante ressaltar que os princípios da administração científica descritos serviram de base para a organização do trabalho fabril.

Em 1903 foi inaugurada a Ford Motor Company e dez anos mais tarde, em 1913, Henry Ford incorporou os princípios tayloristas na linha de montagem de automóveis, tornando-se comum a referência ao método de organização do trabalho denominado "fordismo-taylorismo". Como relatam Fleury e Vargas, Ford apropriou-se da ideia do sistema de carretilhas aéreas usadas nos matadouros de Chicago para esquartejar reses; a esteira rolante passou a ter um funcionamento ininterrupto, combinando operações extremamente parceladas dos trabalhadores. O sucesso dessa forma de produção foi revelado em números: o tempo de montagem do chassi foi reduzido de 12 horas e 8 minutos para 1 hora e 33 minutos. E na linha de montagem, onde a operação era realizada por uma só pessoa, com a esteira rolante ficou dividida por 84 operários.

Esses autores descrevem a realidade de trabalho de um operário em uma linha de produção fordista:

Fixo no seu posto de trabalho, o homem passou a ser quase um componente da máquina. Os seus movimentos deveriam ser feitos mecanicamente sem, segundo Ford, interferência da sua mente, guardando, assim, perfeita harmonia com o conjunto da linha de montagem.

Aquele trabalhador qualificado, antes necessário no processo de montagem, era eliminado. Em seu lugar surgia um novo homem, cuja única função era repetir indefinidamente movimentos padronizados, desprovidos de qualquer conhecimento profissional, que para Ford "nada tem de desagradável". ${ }^{114}$

Ford procurou eliminar os chamados "poros" na linha de produção, isto é, as interrupções da atividade por falta de suprimento de materiais; no modo de organização fordista, a máquina assumia o papel antes delegado ao corpo de planejamento da fábrica. Assim, as peças deslocavam-se automática e ininterruptamente, suprindo todos os homens da produção das peças necessárias, sem paradas. A linha de montagem tornou-se, assim,

\footnotetext{
${ }^{114}$ FLEURY, Afonso Carlos Correia; VARGAS, Nilton et al. Organização do trabalho: uma abordagem interdisciplinar: sete casos brasileiros para estudo. São Paulo: Atlas, 1983. p. 23-24.
} 
notável instrumento de intensificação do trabalho. E essa intensificação do trabalho resultou para o capital no mesmo que o aumento da jornada de trabalho.

Afirmam Fleury e Vargas que a introdução da linha de montagem teve como resultado a desqualificação operária e a intensificação do trabalho. ${ }^{115}$

Observe-se aqui que Adam Smith, em A riqueza das nações, já apresentava argumentos a favor da superioridade tecnológica de uma divisão do trabalho e da importância do ganho de tempo; ressaltando que a invenção de um grande número de máquinas facilita e abrevia o trabalho e permite que um homem realize a tarefa de vários. E a economia de tempo implica a separação das tarefas e a duração de uma atividade, e não a especialização. ${ }^{116}$

Diz Otavio Pinto e Silva que o fordismo-taylorismo continua vivo, pois as novas tecnologias não implicaram necessariamente a adoção de novos conceitos de organização do trabalho, e exemplifica com o trabalho desenvolvido na rede de lanchonetes McDonald's, que se baseia na concepção de administração científica da produção, oferecendo produtos homogêneos em grande escala e mediante rotinas padronizadas de trabalho.

Prossegue esse autor destacando que o desenvolvimento da automação e da microeletrônica trouxe diferentes perspectivas de produção, levando ao surgimento dos modelos que hoje podem ser classificados como pós-fordismo, como no Japão, onde surgiu o chamado toyotismo, método de organização que se caracterizou pelo trabalho em equipe, desenvolvido com uma grande rotação dos trabalhadores pelos postos de trabalho, conforme as necessidades da demanda. ${ }^{117}$

Ricardo Antunes salienta as profundas transformações ocorridas no mundo do trabalho na década de 80 , em especial nos países de capitalismo avançado; foi uma década

\footnotetext{
${ }^{115}$ FLEURY, Afonso Carlos Correia; VARGAS, Nilton et al. Organização do trabalho: uma abordagem interdisciplinar: sete casos brasileiros para estudo. São Paulo: Atlas, 1983. p. 26-27.

${ }^{116}$ GORZ, André. Crítica da divisão do trabalho. São Paulo: Martins Fontes, 2001, p. 235-236.

${ }^{117}$ SILVA, Otavio Pinto e. Subordinação, autonomia e parassubordinação nas relações de trabalho. São Paulo: LTr, 2004. p. 113-114.
} 
de grande salto tecnológico, quando a automação, a robótica e a microeletrônica invadiram o universo fabril, inserindo-se nas relações de trabalho e na produção do capital. Assim, o fordismo e o taylorismo não desaparecem, mesclam-se com outros processos produtivos, denominados de neofordismo, neotaylorismo, pós-fordismo. Novos processos de trabalho surgem, e o cronômetro e a produção em série são substituídos pela "especialização flexível", por novos padrões de busca de produtividade, pela procura de novos padrões de gestão da força de trabalho, nos quais os Círculos de Controle de Qualidade (CCQs) e a busca de "qualidade total" são expressões visíveis não somente no Japão, como também em países desenvolvidos ou mesmo no Terceiro Mundo industrializado. Assim, o toyotismo penetra ou até mesmo substitui o padrão fordista dominante. ${ }^{118}$

Explica Ricardo Antunes que são várias mutações que vêm ocorrendo, que alteram o processo de produção do capital, com repercussões no processo de trabalho. Ensina que o toyotismo pode ser entendido como

"uma forma de organização do trabalho que nasce a partir da fábrica Toyota, no Japão, e que vem se expandindo pelo Ocidente capitalista, tanto nos países avançados quanto naqueles que se encontram subordinados. Suas características básicas (em contraposição ao taylorismo/fordismo) são:

1. Sua produção muito vinculada à demanda.

2. Ela é variada e bastante heterogênea.

3. Fundamenta-se no trabalho operário em equipe, com multivariedade de funções.

4. Tem como princípio o just in time, o melhor aproveitamento possível do tempo de produção e funciona segundo o sistema de kanban, placas ou senhas de comando para reposição de peças e de estoque que, no toyotismo, devem ser mínimos. Enquanto na fábrica fordista cerca de $75 \%$ era produzido no seu interior, na fábrica toyotista somente cerca de $25 \%$ é produzido no seu interior. Ela horizontaliza o processo produtivo e transfere a "terceiros" grande parte do que anteriormente era produzido dentro dela. [...]. ${ }^{119}$

Esse autor critica a chamada "gestão participativa" na busca da "qualidade total", no processo de produção toyotista, evidenciando que a exigência de especialização, a

\footnotetext{
118 ANTUNES, Ricardo. Adeus ao trabalho?: ensaio sobre as metamorfoses e a centralidade do mundo do trabalho. São Paulo: Cortez, 2010. p. 24.

119 Idem, ibidem, p. 196.
} 
presença do operário que pensa, em vez de abrandar, aprofunda a subordinação do trabalhador aos interesses do capital:

A falácia de "qualidade total" passa a ter papel de relevo no processo produtivo. Os Círculos de Controle de Qualidade (CCQ) proliferaram, constituindo-se como grupos de trabalhadores que são incentivados pelo capital para discutir trabalho e desempenho, com vistas a melhorar a produtividade da empresa. Em verdade, é a nova forma de apropriação do saber fazer intelectual do trabalho pelo capital.

O despotismo torna-se então mesclado com a manipulação do trabalho, com o "envolvimento" dos trabalhadores, através de um processo ainda mais profundo de interiorização do trabalho alienado (estranhado). O operário deve pensar e fazer pelo e para o capital, o que aprofunda (ao invés de abrandar) a subordinação do trabalho ao capital. No Ocidente, os CCQ's têm variado quanto à sua implementação, dependendo das especificidades e singularidades dos países em que eles são implementados. [...]. ${ }^{120}$

Em síntese, podemos dizer que no taylorismo o trabalhador foi reduzido à condição de máquina; no fordismo, o trabalho rigidamente especializado e parcelado foi voltado à produção em série, com desqualificação da mão de obra operária e intensificação do trabalho; e no toyotismo, o trabalhador continua trabalhando até o limite de suas forças, e, além disso, deve ser polivalente.

Reportando-nos à Administração Científica, é preciso ressaltar que tal método se preocupava basicamente com a estruturação do trabalho, no sentido de "racionalizar" a tarefa e formalizar as características dos cargos do setor produtivo, com enfoque eminentemente técnico, mecanicista, não só desconsiderando qualquer aspecto do ser humano que não o fisiológico, bem como procurando evitar manifestações de processos sociais no sistema de produção. Tal concepção traz subjacente a ideia de que existem duas hipóteses sobre o comportamento humano: 1) cada homem procura maximizar sua prosperidade em termos econômicos; 2) a ambição individual é um fator de motivação que predomina sobre qualquer outro sentimento. ${ }^{121}$

\footnotetext{
${ }^{120}$ ANTUNES, Ricardo. Adeus ao trabalho?: ensaio sobre as metamorfoses e a centralidade do mundo do trabalho. São Paulo: Cortez, 2010. p. 196.

${ }^{121}$ FLEURY, Afonso Carlos Correia; VARGAS, Nilton et al. Organização do trabalho: uma abordagem interdisciplinar: sete casos brasileiros para estudo. São Paulo: Atlas, 1983. p. 28.
} 
Tais hipóteses se mostraram incorretas e outras propostas surgiram sobre a motivação no trabalho, formuladas a partir da década de 40. São três as teorias consideradas mais influentes, e a primeira a ser mencionada é a de Abraham H. Maslow.

De acordo com a tese formulada por Maslow, "nós funcionamos melhor quando estamos lutando por alguma coisa que necessitamos, quando desejamos alguma coisa que não temos". 122

Formulou a Teoria da Hierarquia de Necessidades, que, segundo esse psicólogo, orienta o comportamento humano, de tal forma que um indivíduo não persegue as necessidades de nível mais elevado, enquanto não tiver satisfeito as necessidades de nível mais baixo. Dessa forma, as necessidades primárias são as necessidades fisiológicas, que constituem a sobrevivência do indivíduo e a preservação da espécie: alimentação, sono, repouso, abrigo etc. Em seguida vêm as necessidades de segurança, que constituem a busca de proteção contra a ameaça ou privação, a fuga e o perigo. As necessidades sociais vêm em terceiro lugar e incluem a necessidade de associação, de participação, de aceitação por parte dos companheiros, de troca de amizade, de afeto e amor. A necessidade de estima envolve a autoapreciação, a autoconfiança, a necessidade de aprovação social e de respeito, de status, prestígio e consideração, além de desejo de força e de adequação, de confiança perante o mundo, independência e autonomia. As necessidades de autorrealização são as mais elevadas nessa pirâmide, e consiste na capacidade de cada pessoa realizar o seu próprio potencial e de se autodesenvolver continuamente. ${ }^{123}$

Nesse sentido, o trabalho somente tem sentido para as pessoas na medida em que algum tipo de necessidade estiver sendo satisfeito. Se analisarmos a Administração Científica taylorista à luz da pirâmide das necessidades de Maslow, constata-se que os fatores enfatizados de acordo com a concepção de Taylor eram somente os físiológicos e os de segurança, e mesmo assim com distância das concepções atuais; não havia espaço para demais necessidades. Maslow marcou o início de uma nova fase para a psicologia

\footnotetext{
${ }^{122}$ FLEURY, Afonso Carlos Correia; VARGAS, Nilton et al. Organização do trabalho: uma abordagem interdisciplinar: sete casos brasileiros para estudo. São Paulo: Atlas, 1983. p. 29.

${ }^{123}$ Disponível em: <http://www.professor.ucg.br/siteDocente/admin/../Teoria\%20de\%20Maslow.doc>. Acesso em: 28 set. 2012.
} 
industrial, que se preocupava unicamente com os testes de seleção e treinamento de pessoal.

Em seguida, surgem as pesquisas de Argyris, denominadas Teoria de Organização e Personalidade; a partir do exame das organizações do trabalho, conclui que elas se fundamentam no modelo do homem imaturo; isso afeta a eficiência da organização, pois o trabalhador pode ser sentir frustração, ter problemas psicológicos; perspectiva de curto prazo e conflito. Nesse contexto, se o trabalhador continua na organização, abandona-a psicologicamente, tornando-se apático. Para Argyris, são os indivíduos, agindo como agentes da organização, que produzem ações aptas à aprendizagem ou, ao contrário, que podem inibir ou produzir barreiras à aprendizagem. ${ }^{124}$ A solução para o problema estaria na modificação das organizações, de forma que permitissem que as pessoas desenvolvessem suas características de adultos no processo de trabalho.

Por fim, Fleury e Vargas enfocam a pesquisa de Herzberg, segundo a qual, em uma situação de trabalho, existem fatores que, se presentes, levam o trabalhador a ficar satisfeito, mas, se não estiverem presentes, não o levam a ficar insatisfeito. Por outro, existem fatores que, se não estiverem presentes, levam o trabalhador à insatisfação, mas se estiverem presentes, inibem a insatisfação, mas não conduzem à satisfação. Herzberg chamou o primeiro grupo de fatores motivadores e o segundo, de fatores de higiene, em analogia à medicina preventiva. Prosseguem Fleury e Vargas, distinguindo que:

Os fatores motivadores são os que propiciam o crescimento psicológico da pessoa, e são todos eles relacionados à organização do trabalho: realização, interesse intrínseco pelo trabalho, reconhecimento pela realização, responsabilidade e promoção. Por sua vez, os fatores higiênicos estão voltados para "evitar o sofrimento", e não estão ligados diretamente ao trabalho que a pessoa desenvolve: política da companhia e práticas administrativas, supervisão, relações interpessoais, condições de trabalho e salário. ${ }^{125}$

Assim, Herzberg corrobora a teoria de Argyris, no sentido de que o único modo de fazer com que as pessoas estejam satisfeitas no trabalho, e em decorrência, sejam

\footnotetext{
${ }^{124}$ SOUZA, Yeda Swirski de. Organizações de aprendizagem ou aprendizagem organizacional. Disponível em: <http://www.scielo.br/pdf/raeel/v3n1/v3n1a08>. Acesso em: 2 out. 2012.

125 FLEURY, Afonso Carlos Correia; VARGAS, Nilton et al. Organização do trabalho: uma abordagem interdisciplinar: sete casos brasileiros para estudo. São Paulo: Atlas, 1983. p. 31.
} 
pessoas produtivas no trabalho, é estruturar os cargos de maneira adequada à personalidade das pessoas.

Felice Battaglia aponta os obstáculos à satisfação no trabalho, ou obstáculos à alegria do trabalho, dizendo que são certamente os de ordem social:

[...] a impressão de que o salário não seja equânime, i. e., não seja suficiente para a vida, enquanto que o lucro do empreendedor coloca este último em condições privilegiadas; que a hierarquia da fábrica é muito opressiva; que o operário pertence a uma classe deserdada e desprovida de tudo, desestimada na desestima social que envolve o trabalho manual; que este não apresenta nenhuma segurança de vida e de subsistência. [...]. ${ }^{126}$

Esse autor, reportando-se a De Man, afirma que as objeções que se fazem ao salário cairiam se este, em vez de ser fixado unilateralmente pelo patrão, fosse consequência de um acordo contratual entre trabalhadores e "propiciadores do trabalho". ${ }^{127}$

Enfim, são vários os fatores que podem levar à insatisfação no trabalho; o salário aviltante pode afetar a subsistência e até mesmo a segurança, caso não se consiga obter com o ganho uma moradia digna. Um ambiente de trabalho autoritário, hostil, também é fator de insatisfação, quando não também de adoecimento.

Cabe refletir que, mesmo com a evolução tecnológica e com a crescente preocupação louvável com o meio ambiente, tais fatores não necessariamente repercutem de forma positiva no processo de organização do trabalho.

Como dissemos, e de acordo com a pesquisa de Herzberg, existem fatores que, se presentes no ambiente de trabalho, levam o trabalhador a ficar satisfeito. Nessa linha, surge a chamada "nova administração" a partir de meados da década de 70, identificando no lado humano e pessoal da organização o principal problema a ser enfrentado, para superar um baixo nível de comprometimento e motivação, tanto do corpo administrativo quanto dos operários. Na busca de alteração dessa situação, introduziu-se um "estilo democrático de administração", que essencialmente passa a considerar que o "conflito não é mais um

\footnotetext{
${ }^{126}$ BATTAGLIA, Felice. Filosofia do trabalho. São Paulo: Saraiva, 1958. p. 271.

${ }^{127}$ Idem, ibidem.
} 
problema, mas um meio de administração do problema". Assim, as características desse novo estilo de administrar são: "canais de comunicação desobstruídos, não formalismo nas relações, diálogo aberto e franco, negociação, descentralização, responsabilidades plenamente assumidas pelas partes e ausências de paternalismo". ${ }^{128}$

É sabido, no entanto, que essa forma democrática de administrar pode ser encontrada em modernas e desenvolvidas organizações, mas não é prática comumente adotada; ao contrário, as empresas que fazem uso desse estilo democrático de gestão são identificadas, pois não são incontáveis, e utilizadas como exemplo.

Vários aspectos do processo de organização do trabalho podem configurar não somente óbices à alegria do trabalho, como diz Battaglia, como também propiciar o acometimento de doenças ou ocorrências de acidentes do trabalho. As características da organização do trabalho e seu impacto na saúde do trabalhador estão diretamente relacionados com aspectos como a duração e a distribuição da jornada de trabalho; o grau de monotonia da tarefa; a cadência, com intensificação do ritmo de trabalho; a repetitividade do ciclo de realização das operações; a possibilidade de participação do empregado no desenvolvimento e resultado do seu trabalho, de forma a perceber a importância de seu papel e da execução das suas tarefas para a organização.

Dependendo da forma como se dá o processo de organização do trabalho, podem se configurar como estressores organizacionais e ambientais os seguintes fatores relacionados ao trabalho, entre outros: controle no trabalho; pausas curtas; sistema de remuneração esforço/recompensa; nível de ruído excessivo no ambiente laboral. Ilustremse, dentre as "pausas curtas", a usual ausência de intervalos regulares intrajornada, para refeição e descanso; o desrespeito entre o intervalo mínimo legal entre as jornadas diárias; e também a falta de descanso nos dias de repouso semanal e feriados. É comum ocorrer, ainda que de maneira "informal", o gozo de férias "picadas" em número de dias inferiores ao legalmente permitido, impossibilitando o efetivo descanso e a reparação das forças físicas e mentais do trabalhador.

${ }^{128}$ FLEURY, Afonso Carlos Correia; VARGAS, Nilton et al. Organização do trabalho: uma abordagem interdisciplinar: sete casos brasileiros para estudo. São Paulo: Atlas, 1983. p. 130. 
Examinemos de início o fator tempo de trabalho, isto é, a jornada de trabalho e a prática comum da prorrogação de jornada. No Brasil, o trabalho extraordinário ainda é prática tão frequente, que há vasta construção jurisprudencial dos Tribunais do Trabalho no tocante à prestação de horas extras habituais; a jurisprudência usualmente é voltada à remuneração.

O trabalho por jornadas prolongadas impede o equilíbrio homeostático, acarreta o agravamento da fadiga, conforme será mais bem analisado no tópico dos danos decorrentes do trabalho.

Além da extensão da jornada, um aspecto importante a ser examinado é o horário em que o trabalho é desenvolvido. As jornadas em turno de revezamento e em particular as jornadas noturnas são as que mais agravos trazem à saúde do trabalhador. Cabe aqui observar que não temos no Brasil dados de quantos trabalhadores trabalham em turnos. Em 1994, levantamento da Fundação Seade na área metropolitana de São Paulo caracterizou como trabalhador em turnos ou noturno $8,6 \%$ da população. Valendo-se desses dados, estima-se haver cerca de $10 \%$ da população brasileira ativa que trabalha em turnos ou à noite. $^{129}$

Um dos grandes problemas relacionados com o regime de revezamentos é a chamada "dobra de turno", que ocorre quando o trabalhador, que viria substituir aquele que está encerrando a jornada, falta; em vez da empresa providenciar um substituto, no mais das vezes, há um prolongamento da jornada daquele que estava prestes a deixar o posto de trabalho. Os trabalhadores encaram esse problema como um "castigo", como "o pior que pode acontecer". Acrescentam Fleury e Vargas que essas "dobras" costumam não ser inferiores a oito horas por um problema de transporte; quem faz a dobra não interrompe o serviço, pois não dispõe de transporte para retornar. ${ }^{130}$ Isso é comum acontecer, por exemplo, em usinas siderúrgicas, que não podem interromper sua produção: setores como a aciaria, junto ao alto forno, funcionam 365 dias ao ano, e 24 horas por dia.

\footnotetext{
${ }^{129}$ MORENO, Cláudia Roberta de Castro; FISCHER, Frida Marina; ROTENBERG, Lúcia. A saúde do trabalhador na $\quad$ sociedade $24 \quad$ horas. $<$ https://www.seade.gov.br/produtos/spp/v17n01/v17n01_04.pdf>. Acesso em: 3 out. 2012.

${ }^{130}$ FLEURY, Afonso Carlos Correia; VARGAS, Nilton et al. Organização do trabalho: uma abordagem interdisciplinar: sete casos brasileiros para estudo. São Paulo: Atlas, 1983. p. 137.
} 
As condições de trabalho: meio ambiente ergonomicamente inadequado; trabalho perigoso, com risco à integridade física; trabalho insalubre, com contato com agentes físicos, químicos ou biológicos, minam a saúde do trabalhador, causam desconforto e adoecimento.

Outro fator importante, que causa grande impacto na saúde do trabalhador, é a forma de remuneração: quando o salário é atrelado ao rendimento, o chamado esforço/recompensa. O sistema de remuneração por tarefa ou peça, por exemplo, é previsto no art. 78 da Consolidação das Leis do Trabalho (CLT); fixado em proporção à quantidade de energia efetivamente prestada, medida na forma de produção ao final obtida. Como destaca Nadia Demoliner Lacerda, "nesta modalidade de remuneração a expectativa de maior rendimento impulsiona o trabalhador a desenvolver mais rapidez na execução da tarefa, a fim de manter um rendimento estável, o que contribui para o desenvolvimento de um estado de fadiga geral [...]". ${ }^{131}$

Enfim, a forma pela qual se articulam o processo de trabalho e a sua administração é fundamental não apenas para a produção, como também para a saúde dos trabalhadores.

Afirma Christophe Dejours que quanto mais rígida a organização do trabalho, menos ela facilitará estruturações favoráveis ao que esse autor chama de "economia psicossomática individual”. Prossegue dizendo:

A organização do trabalho é causa de uma fragilização somática, na medida em que ela pode bloquear os esforços do trabalhador para adequar o modo operatório às necessidades de sua estrutura mental.

É provável que uma parte não negligenciável da morbidade somática observada entre os trabalhadores tenha sua origem numa organização de trabalho inadequada. As mesmas observações aplicam-se à diminuição da longevidade dos trabalhadores à medida que se desce na hierarquia socioprofissional, pois - via de regra - quanto mais se desce no status social, mais rigidamente determinada é a organização do trabalho que os trabalhadores enfrentam [...]. ${ }^{132}$

\footnotetext{
${ }^{131}$ LACERDA, Nadia Demoliner. Segurança e saúde do trabalhador: para onde vamos? O debate nacional sobre a concepção preventiva do novo seguro de acidente. São Paulo: LTr, 2011. p. 30.

${ }^{132}$ DEJOURS, Christophe. A loucura do trabalho. São Paulo: Cortez - Oboré, 1988. p. 128.
} 
Nesse sentido, a organização do trabalho que adota tratamento rigoroso, vexatório, quando das ordens e físcalização do serviço ou exige produtividade superior às forças físicas e mentais do trabalhador, por certo propiciará desgaste e danos à saúde mental ou psíquica do trabalhador.

Ao mesmo tempo em que se constata que os trabalhadores com posição inferior no status social são submetidos a processos rígidos de organização do trabalho, as empresas desenvolvem estratégias e um controle sofisticado, para "conquistar a alma de seus executivos", como ensina Edith Seligmann Silva:

Assim, Pagès et al. (1987), a partir do estudo de uma empresa multinacional, analisaram como as políticas e as práticas de recursos humanos conduzem à concretização dos princípios e das crenças derivados da ideologia empresarial. A íntima coerência, que se estabelece entre a ideologia e os dispositivos operacionais adotados, mostra-se eficaz no objetivo de interiorizar, em cada funcionário, os princípios, as crenças e as atitudes ditadas pela ideologia da empresa.

No estudo de Pagès et al. (1987), o poder é identificado como um sistema inserido sobre quatro eixos básicos de distinta natureza, mas intimamente conectados. As coordenadas desse sistema seriam as seguintes: 1) ideológica; 2) política; 3) econômica; 4) psicológica. Os autores procuraram demonstrar que a instância econômica se tornou hegemônica no sistema de poder existente no interior das modernas organizações transnacionais, pois os objetivos visados são, também, fundamentalmente, de natureza econômica.

No nível psicológico, ainda conforme Pagès et al., as políticas de recursos humanos realizam uma verdadeira gestão dos afetos, conduzindo a investimento maciço dos sentimentos na organização, pela via inconsciente, e possibilitando, desse modo, a dominação da organização sobre o aparelho psíquico. Assim, as políticas de recursos humanos ocasionam, simultaneamente, a incorporação das crenças fabricadas pela organização e também garantem o respeito às regras fixadas em consonância com essas crenças. [...]. ${ }^{133}$

\footnotetext{
${ }^{133}$ SILVA, Edith Seligmann. Trabalho e desgaste mental: o direito de ser dono de si mesmo. São Paulo:
} Cortez, 2011. p. 168-169. 


\section{Ensina Christophe Dejours que}

[...] quando a relação com a organização do trabalho é favorável, ao invés de ser conflituosa, é porque pelo menos uma das duas condições é realizada: a) as exigências intelectuais, motoras ou psicossensoriais da tarefa estão de acordo com as necessidades do trabalhador considerado, de tal maneira que o simples exercício da tarefa está na origem de um "prazer de funcionar"; b) o conteúdo do trabalho é fonte de uma satisfação sublimatória, que é rara em comparação com a maioria das tarefas, encontrada em circunstâncias privilegiadas, onde a concepção do conteúdo, do ritmo de trabalho e do modo operatório é em parte, deixada ao trabalhador, que pode, então, modificar a organização do seu trabalho conforme seu desejo ou suas necessidades. [...]. ${ }^{134}$

Afirma esse autor que tais condições só se encontram nas profissões de artesão, nas profissões liberais e nas de alto nível. Na realidade, não se pode dizer, nem mesmo em relação a essas profissões, que seu exercício se dá em condições ideais. O profissional liberal, por exemplo, o advogado, vive premido pelos prazos, pela necessidade de satisfazer o cliente e nem sempre obtém ganhos suficientes para uma vida sem preocupações; e as profissões de alto nível, caso dos altos executivos, são submetidas a sofisticadas estratégias de pressão e controle, como entende Edith Seligmann Silva, já citada.

Atualmente muito comentado em decorrência das incontáveis ações trabalhistas onde são pleiteadas indenizações por dano moral, o fenômeno chamado "assédio moral" é tratado por Maria Ester de Freitas, Roberto Heloani e Margarida Barreto, que de início alertam para o risco de que seja confinado a um mero conflito entre indivíduos psicologizados e desconsiderada a responsabilidade da organização do trabalho. Dizem que a chantagem do emprego e a pressão contínua e crescente podem ser mascaradas na atribuição de culpa aos indivíduos perversos, mas sabe-se que essa relação perversa nutrese da institucionalização e do encorajamento de modelo de gestão fundado em maus-tratos e na promoção de responsáveis organizacionais, que encontram prazer em reforçar ou imprimir o sofrimento no ambiente de trabalho, em vez de buscar reduzi-lo. ${ }^{135}$

\footnotetext{
${ }^{134}$ DEJOURS, Christophe. A loucura do trabalho: estudo de psicopatologia do trabalho. São Paulo: Cortez Oboré, 1988. p. 134.

${ }^{135}$ FREITAS, Maria Ester de; HELOANI, Roberto; BARRETO, Margarida. Assédio moral no trabalho. São Paulo: Cengage Learning, 2009. p. 13.
} 
Definem esses autores que

[...] o assédio moral é uma conduta abusiva, intencional, frequente e repetida, que ocorre no ambiente de trabalho e que visa diminuir, humilhar, vexar, constranger, desqualificar e demolir psiquicamente um indivíduo ou um grupo, degradando as suas condições de trabalho, atingindo a sua dignidade e colocando em risco a sua integridade pessoal e profissional. ${ }^{136}$

Como ensina Roberto Heloani, existem formas desastrosas de gestão, podendo ser elencados: o despotismo - relações desumanas no trabalho; relações aéticas; Programa de Desligamento Voluntário - PDV e congêneres; programas de metas cada vez mais inatingíveis; avaliações unilaterais, não participativas e gestão perversa.

Quem mais pratica o assédio moral, usualmente, são superiores hierárquicos, os que têm mais poder; um colega ou um conjunto de colegas de trabalho, quando se dá o chamado assédio moral horizontal; ou os subordinados - é o denominado assédio moral ascendente, que ocorre em menor índice, mas vem apresentando crescimento. Reflexo de uma sociedade em que as minorias ainda são vítimas da dominação, constata-se que a mulher é mais assediada que o homem; a mulher negra é vítima de assédio com maior frequência que a branca; as pessoas com deficiência sofrem mais assédio do que as que não possuem e os homoafetivos são mais assediados do que os heterossexuais.

De todo modo, ainda que não exista uma forma perfeita de se organizar o trabalho, e que as imperfeições e desgastes sejam decorrências da natureza humana, é preciso reiterar que a forma mais democrática e participativa possível da organização do trabalho sempre levará ao bom desempenho dos trabalhadores, em condições de maior segurança; trata-se de premissa que envolve a obtenção da motivação por parte dos trabalhadores, por meio de mecanismos para atingir a satisfação, com autonomia e responsabilidade.

No entanto, como diz Francisco Lacaz, no Brasil a possibilidade de organização dos trabalhadores nos locais de trabalho, que deveria ser um dos pilares da busca pela qualidade do trabalho, é uma realidade muito pouco encontrada, quando não considerada

\footnotetext{
${ }^{136}$ FREITAS, Maria Ester de; HELOANI, Roberto; BARRETO, Margarida. Assédio moral no trabalho. São Paulo: Cengage Learning, 2009. p. 37.
} 
indesejável ou até ilegal, dada a histórica repulsa do patronato às manifestações de independência e autonomia das classes trabalhadoras. Salienta esse autor que a organização nos locais de trabalho deveria ser elemento norteador das relações de trabalho, em vista da introdução de novas tecnologias e da automação cada vez mais intensa; afirma o autor que é inadmissível falar em qualidade do produto sem tocar na qualidade dos ambientes e condições de trabalho. ${ }^{137}$

\subsubsection{A globalização da economia e a precarização das relações de trabalho}

O capitalismo vem sofrendo profundas mudanças, desde o final do século XX; o modelo de Estado interventor entra em crise, ilustrada pelo colapso da União Soviética e dos regimes dos países do Leste europeu, como destaca Otavio Pinto e Silva. ${ }^{138}$ Observa-se uma intensificação do processo de internacionalização da economia capitalista.

A partir dos anos 80, em decorrência da inserção da tecnologia nas áreas da informática, das comunicações e nas atividades econômicas em geral, houve assombroso impulso do processo de globalização, como ensina Gilberto Dupas. ${ }^{139}$

Explica esse autor que as estratégias de produção e distribuição das corporações foram reformuladas, passando da empresa integrada verticalmente a networks, que incorporam diferentes empresas em um mesmo projeto global. Neste processo, tecnologia e capital adquiriram mobilidade crescente, acelerada pela possibilidade de fragmentação das cadeias produtivas. ${ }^{140}$

Tal fenômeno tornou o mercado volátil e altamente competitivo, de modo que as relações de trabalho passaram por profundas modificações, acarretando, por conseguinte, a flexibilização da mão de obra, como ensina Otavio Pinto e Silva, ao elencar as principais tendências das transformações do processo de produtivo:

\footnotetext{
${ }^{137}$ LACAZ, Francisco Antônio de Castro. Qualidade de vida no trabalho e saúde/doença. Ciência e Saúde Coletiva, n. 5, p. 151-161, 2000.

${ }^{138}$ SILVA, Otavio Pinto e. Subordinação, autonomia e parassubordinação nas relações de trabalho. São Paulo: LTr, 2004. p. 141.

${ }^{139}$ DUPAS, Gilberto. A lógica da economia global e a exclusão social. Estudos Avançados, São Paulo, v. 12, n. 34, p. 124, set.-dez. 1998.

${ }^{140}$ Idem, ibidem.
} 
a) redução da geração de empregos qualificados e formais por investimento direto;

b) contínua flexibilização da mão de obra, tendo em vista o objetivo de transformá-la em componente variável do custo final dos produtos;

c) inter-relação entre agentes econômicos formais e informais, procurando abrigar na base das cadeias produtivas o trabalho informal e a mão de obra barata e de baixa qualificação. ${ }^{141}$

Ricardo Antunes lembra algumas expressões do novo dicionário do capital, desregulamentação, flexibilização, terceirização, downsizing, "empresa enxuta", que revelam mais uma vez a lógica da prevalência do capital sobre a força humana de trabalho, considerada na medida em que é imprescindível para a reprodução desse mesmo capital. Ressalta que o capital pode diminuir o trabalho vivo, mas não eliminá-lo. Assim, não se constata o fim do trabalho, mas sua mudança qualitativa. ${ }^{142}$

Nessa linha, esse autor salienta o enorme incremento do novo proletariado, do trabalho precarizado; elenca as formas atuais do subproletariado, os terceirizados, subcontratados, part time, que se espalham ao redor do mundo. ${ }^{143}$

Essa desestruturação do mercado de trabalho gera a redução dos empregos formais, a ampliação do desemprego visível, como diz Otavio Pinto e Silva, reportando-se à pesquisa de Marcio Pochmann. ${ }^{144}$ E ainda que o nível de desemprego tenha caído nos últimos anos, fruto do recente aquecimento da economia nacional, em melhor situação que muitos países europeus, ainda é elevado o número de desempregados, como ilustram as informações da Pesquisa de Emprego e Desemprego (PED), realizada pela Fundação Seade e pelo Dieese. Os dados mostram que, em agosto, a taxa de desemprego total na Região Metropolitana de São Paulo elevou-se, ao passar de 11,1\%, em julho, para os atuais 11,6\%, em movimento não usual para o período. Segundo suas componentes, a taxa de

\footnotetext{
${ }^{141}$ SILVA, Otavio Pinto e. Subordinação, autonomia e parassubordinação nas relações do trabalho. São Paulo: LTr, 2004. p. 143.

${ }^{142}$ ANTUNES, Ricardo. Adeus ao trabalho?: ensaio sobre as metamorfoses e a centralidade do mundo do trabalho. São Paulo: Cortez, 2010. p. 199.

${ }^{143}$ Idem, ibidem, p. 197.

${ }^{144}$ SILVA, Otavio Pinto e. Subordinação, autonomia e parassubordinação nas relações do trabalho. São Paulo: LTr, 2004. p. 144.
} 
desemprego aberto variou de $9,1 \%$ para $9,4 \%$ e a de desemprego oculto, de $2,0 \%$ para $2,2 \%{ }^{145}$

Não somente o desemprego, como também a precarização dos postos de trabalho e a desmedida terceirização, impedem a socialização pelo trabalho. Os chamados trabalhadores terceirizados muitas vezes prestam serviços para várias tomadoras ao longo do contrato de trabalho com a empresa de prestação de serviços; nas tomadoras muitas vezes sequer são "vistos"; são discriminados e submetidos, via de regra, a tarefas de maior risco, sem treinamento e em condições inseguras de trabalho.

Como acertadamente afirma Guilherme Purvin de Figueiredo, se a liberdade política está presente, o desemprego e a crescente insegurança na área social inviabilizam seu exercício democrático pleno. Prossegue enfocando a verdadeira chaga social que é o desemprego, dizendo que:

[...] de um lado, temos uma crescente legião de desempregados. Estes, à medida que passam os dias nessas condições, menores perspectivas têm de resgatar os níveis de qualidade de vida - de dignidade humana - que um dia experimentaram. Nesta situação, todos são marginalizados no processo econômico e social e buscam no trabalho chamado informal os meios para a sua sobrevivência. E não há como fugir à evidência, no quadro desenhado pelo trabalho informal os fatores segurança e saúde são relegados a um plano inteiramente secundário. [...] as condições de vida e trabalho, em todos os lugares, estão sendo revolucionadas pelos processos que provocam, induzem ou comandam a globalização. A nova divisão transnacional do trabalho e da produção transforma o mundo em uma fábrica global. A mundialização dos mercados de produção, ou forças produtivas, tanto provoca a busca de força de trabalho barata em todos os cantos do mundo como promove as migrações em todas as direções. $\mathrm{O}$ exército industrial de trabalhadores, ativo e de reserva, modifica-se e movimenta-se, formando contingentes de desempregados mais ou menos permanentes ou subclasses, em escala global. ${ }^{146}$

Importa dizer, como destaca esse autor, que a doença profissional, o acidente do trabalho, a poluição do ar, da água e a degradação do solo constituem efeitos nocivos e indesejados, as chamadas externalidades, de um sistema de produção criado pela classe

\footnotetext{
${ }^{145}$ Pesquisa de Emprego e Desemprego. Região Metropolitana de São Paulo. Fundação Seade, agosto de 2012. Disponível em: <http://www.seade.gov.br/produtos/ped/pedv98/pdf/rmsp_ago2012.pdf>. Acesso em: 7 out. 2012.

${ }^{146}$ FIGUEIREDO, Guilherme José Purvin de. Direito ambiental e a saúde dos trabalhadores. São Paulo: LTr, 2007. p. 28.
} 
dominante e imposto à classe trabalhadora, sistema que elegeu como valor maior o lucro em lugar do bem-estar social. ${ }^{147}$

\subsubsection{Danos físicos e transtornos psíquicos decorrentes do trabalho}

Como dissemos no tópico sobre o processo de organização do trabalho, podem se configurar como estressores organizacionais e ambientais determinados fatores relacionados ao trabalho, destacando-se, dentre eles, o trabalho extraordinário, por sua nocividade à saúde do trabalhador.

Ensina Sebastião Geraldo de Oliveira que o organismo humano, quando se encontra em situação de inalterabilidade de suas condições internas, está em equilíbrio homeostático. Com o aquecimento proveniente do esforço físico, o organismo aciona os mecanismos de homeostase, provocando a sudorese, o aumento dos batimentos cardíacos acelera o sistema circulatório e provoca a vasodilatação periférica, para maior aporte sanguíneo nos tecidos. A execução do trabalho consome calorias, e, com o dispêndio energético para manter o organismo em equilíbrio homeostático, vem o cansaço, e o organismo necessita de descanso para sua recomposição. Por isso, o prolongamento das atividades nesse quadro acarreta:

[...] o agravamento crescente da fadiga, a qual representa uma reação do organismo, sinalizando para a interrupção do trabalho, como mecanismo de conservação da vida. $\mathrm{O}$ esforço adicional, como ocorre no trabalho constante em horas extras, aciona o consumo das reservas energéticas e o aceleramento da fadiga pode levar à exaustão ou esgotamento. [...]

Um processo prolongado de fadiga induz à instalação da fadiga crônica, que não cede nem mesmo com o repouso diário. Esse quadro de fadiga patológica compromete o sistema imunológico, deixando o trabalhador mais vulnerável às doenças, além de produzir insatisfação com o serviço, absenteísmo, baixa produtividade e maior número de acidentes do trabalho. [...]. ${ }^{148}$

Saliente-se que o trabalho realizado em turnos e especialmente o trabalho noturno é o que causa mais malefícios à saúde do trabalhador, como afirma Frida Marina

\footnotetext{
${ }^{147}$ FIGUEIREDO, Guilherme José Purvin de. Direito ambiental e a saúde dos trabalhadores. São Paulo: LTr, 2007. p. 29.

148 OLIVEIRA, Sebastião Geraldo de. Proteção jurídica à saúde do trabalhador. 5. ed. São Paulo: LTr, 2010. p. 149
} 
Fischer. ${ }^{149} \mathrm{O}$ funcionamento do corpo humano, assim como o da natureza, é rítmico. Nosso genoma contém a programação de como devemos funcionar e que tipo de reação vamos sofrer, por influência de questões temporais. Recebemos as chamadas "pistas temporais", de quando é dia ou se já é noite; o entorno social e a presença ou ausência de luz regulam nosso comportamento. O sistema nervoso central, por meio do hipotálamo, controlador principal do funcionamento do nosso organismo, como uma espécie de "relógio", reconhece se é dia ou noite, a partir dos estímulos recebidos. Pode-se dizer que o "tempo entra pelos olhos", pois a luz estimula a retina, e, por meio dessa estimulação, a glândula pineal deixa de produzir melatonina. Assim, quando é dia, a glândula não produz essa substância. E quando a luz vai desaparecendo, já com um ambiente sombreado, iniciase a produção de melatonina, que induz ao sono. Essa substância de regra é produzida à noite, e em pouquíssima quantidade durante o dia, mesmo com cortinas cerradas.

No trabalho noturno, o trabalhador recebe luz durante a noite, a melatonina deixa de ser produzida por estímulo da luz artificial, e por isso o indivíduo fica acordado; esse trabalhador irá dormir mal durante o dia, pois, conforme dissemos, não haverá produção de melatonina.

Portanto, desrespeita-se o ciclo circadiano, de ativação psicossomática e de vigília durante o dia e de desativação e de sono durante a noite. Outro fator prejudicial à saúde humana em relação ao trabalho noturno é que a produção de células de defesa do organismo se dá quando em repouso. Por tudo isso, é errado dizer que a pessoa se adapta ao trabalho noturno; pode ser tolerado, uns mais, outros menos.

Os riscos à saúde associados ao trabalho noturno e em turnos, comparado ao trabalho diurno, são: de evidência média, quanto ao risco de úlcera péptica, câncer de mama, doença cardíaca coronariana, e de acidentes do trabalho; e há evidência elevada quanto ao risco de insônia e de privação do sono. Além disso, a concentração de triglicérides, os aumentos do índice de massa corporal, de gordura abdominal e hiperglicemia estão ligados ao distúrbio do sono e ao risco de doença coronariana. ${ }^{150}$

\footnotetext{
${ }^{149}$ FISCHER, Frida Marina. Organização do trabalho em turnos e noturno. Seminário realizado na Fundacentro, 20 ago. 2012.

${ }^{150}$ Idem, ibidem.
} 
Existem, em determinados locais de trabalho, por exemplo, em hospitais, em que são necessários o atendimento ininterrupto e o trabalho noturno, locais para repouso; observe-se, no entanto, que esses locais normalmente são destinados apenas para médicos; os trabalhadores da enfermagem não têm essa possibilidade. A disponibilização de local para repouso é medida positiva de intervenção no ambiente de trabalho, pois possibilita o repouso, que por sua vez aumenta a segurança nas atividades laborativas, é benéfico à saúde do trabalhador e, ademais, aumenta a produtividade. ${ }^{151}$

E no tocante à forma de remuneração atrelada ao rendimento, que leva o trabalhador a intensificar o ritmo na execução da tarefa, a fim de obter um ganho estável, propicia um estado de fadiga geral, em razão da incerteza e do estado de tensão em atingir as metas de produtividade. Segundo Nadia Demoliner Lacerda, os trabalhadores submetidos a essa forma de produção, assim afetados, apresentam-se mais emotivos, menos sociáveis, às vezes depressivos, estados normalmente acompanhados de mal-estar, dores de cabeça, vertigens, transtornos nas funções cardíacas e respiratórias, falta de apetite, problemas digestivos e insônia. ${ }^{152}$

A tensão no cenário econômico e a instabilidade que ronda o mercado influenciam principalmente a agenda dos executivos, que passam a cumprir jornadas de trabalho cada vez mais extensas; os profissionais ficam até tarde nos escritórios e o trabalho invade os finais de semana, impedindo o descanso, o lazer e o convívio com a família. De acordo com Roberto Heloani, três fatores ajudam a esclarecer a ampliação dos horários: o medo da demissão, a redução de pessoal e o tempo exigido para a tomada de decisões. Há relato de ocupante de cargo de gerência que passou a trabalhar até 18 horas por dia, e, em decorrência, separou-se da esposa e foi acometido de gastrite. ${ }^{153}$

Os sintomas de ansiedade ou estresse podem naturalmente favorecer a adaptação. Entretanto, não havendo período suficiente para a recuperação do esforço psíquico, o qual

${ }^{151}$ FISCHER, Frida Marina. Organização do trabalho em turnos e noturno. Seminário realizado na Fundacentro, 20 ago. 2012.

${ }^{152}$ LACERDA, Nadia Demoliner. Segurança e saúde do trabalhador: para onde vamos? O debate nacional sobre a concepção preventiva do novo seguro de acidente. São Paulo: LTr, 2011. p. 30.

${ }^{153}$ Jornada de executivos tem alta com cenário instável. Folha de S. Paulo, caderno Carreiras e Empregos, 9 out. 2011, p. 1. 
restabeleceria a saúde, ou persistindo continuadamente os estímulos de ameaça que desencadeiam a reação de estresse, nossos recursos para a adaptação acabam por exaurirse, ocorrendo o esgotamento, como diz o próprio nome, um estado em que nossas reservas de recursos para a adaptação se acabam.

Doença insidiosa que ataca a motivação, sem distinção de cargos, é a chamada "síndrome de Burnout", termo em inglês que significa a combustão completa; está incluída no rol dos transtornos mentais relacionados ao trabalho e foi a terceira maior causa de afastamento do trabalho em 2009, de acordo com a Previdência Social. Esse transtorno psíquico é gerado pela percepção de que o esforço colocado no trabalho é superior à recompensa. A pessoa se sente injustiçada e vai se alienando, apresentando sintomas como depressão, fobias e dores musculares, de acordo com a psicóloga Ana Maria Rossi, presidente no Brasil da Isma (International Stress Management Association), entidade que pesquisa a moléstia. ${ }^{154}$

Definida por alguns autores como uma das consequências mais marcantes do estresse profissional, a síndrome de Burnout se caracteriza por exaustão emocional, avaliação negativa de si mesmo, depressão e insensibilidade em relação a quase tudo e todos, até como mecanismo de defesa emocional. Essa síndrome representa o quadro que poderíamos chamar popularmente de "saco cheio" ou "não aguento mais". Parece haver uma preponderância do transtorno nas mulheres, possivelmente em virtude da "dupla jornada de trabalho", o acúmulo da prática profissional com as tarefas domésticas e responsabilidades familiares. A síndrome de Burnout está associada com frequência a outros transtornos emocionais, como depressão e/ou ansiedade, e seria o resultado da combinação entre as características individuais do paciente com as condições do ambiente ou do trabalho, que geraria excessivos e prolongados momentos de estresse no trabalho. Essa síndrome eclode mais em profissionais que mantêm uma relação constante e direta com outras pessoas, principalmente em atividades consideradas de ajuda (médicos, enfermeiros, professores). ${ }^{155}$

\footnotetext{
${ }^{154}$ Folha de S. Paulo, caderno Equilíbrio, 2 nov. 2010, p. 6.

${ }^{155}$ BALLONE, G. J. Síndrome de Burnout. Disponível em: <http://www.psiqweb.med.br>. Acesso em: 9 out. 2012.
} 
Além disso, o assédio moral, como lembram Freitas, Heloani e Barreto, é em si um problema organizacional simplesmente porque ocorre dentro do ambiente de trabalho, entre pessoas que são parte da estrutura organizacional. ${ }^{156}$

Revelam os autores que a elevação da violência no trabalho levou a Organização Mundial da Saúde a pesquisar o assunto e a Organização Internacional do Trabalho (OIT) a publicar um relatório sobre violência no trabalho, de 1996, que apresentava um quadro assustador; naquela época, uma pesquisa realizada em 15 países que compunham a Comunidade Europeia apresentou resultados com variedade de comportamentos violentos no universo do trabalho, como: homicídios, estupros, assédio sexual e assédio moral, entre outros. De acordo com o relatório, em 1996, 12 milhões de pessoas se disseram vítimas de assédio moral naqueles países. ${ }^{157}$

Alguns modelos de gestão movidos à competitividade nociva e à exploração do trabalho sob assédio moral, pressões por desempenho e humilhações podem estar por trás de um ato extremo: o suicídio. O assédio moral é uma das causas de ocorrência de casos de suicídio consumado; ilustram Freitas, Heloani e Barreto: na Suécia 15\% dos suicídios cometidos tiveram como causa o assédio moral.

Margarida Barreto, quando realizou sua pesquisa para elaboração de dissertação de mestrado, posteriormente publicada na obra Violência, saúde e trabalho (uma jornada de humilhações), revelou que, de 2.072 entrevistados, 42\% sofriam de humilhações constantes em seus ambientes laborais e $16 \%$ desse grupo já havia pensado em se matar. ${ }^{158}$

Em 2009, o trabalho Patologia da solidão: o suicídio de bancários no contexto da nova organização do trabalho, dissertação de mestrado em Administração de Empresas, de Marcelo Augusto Finazzi Santos, na Universidade de Brasília (UnB), apurou que 181 bancários terminaram com a própria vida de 1996 a 2005, em média, um a cada 20 dias;

\footnotetext{
${ }^{156}$ FREITAS, Maria Ester de; HELOANI, Roberto; BARRETO, Margarida. Assédio moral no trabalho. São Paulo: Cengage Learning, 2009. p. 37.

${ }^{157}$ Idem, ibidem, p. 17.

158 BARRETO, Margarida Maria Silveira. Violência, saúde e trabalho: uma jornada de humilhações. São Paulo: Educ, 2006. p. 29.
} 
entre as principais causas: assédio moral, pressões por metas, excesso de tarefas e medo do desemprego. ${ }^{159}$

Ressalte-se que o monitoramento no ambiente de trabalho, por meio de tecnologias de controle, tem criado novas situações de dano moral, com pedidos de indenização na Justiça do Trabalho. As empresas se defendem afirmando que o uso das câmeras visa à segurança dos trabalhadores e proteção do patrimônio. No entanto, as alegações dos empregados são no sentido de que são constantemente vigiados; se há conversa com os colegas, se usam os celulares, se vão ao banheiro. Uma ex-empregada de call center, que ajuizou reclamação trabalhista em face da empresa depois de ter sido diagnosticada com depressão e síndrome do pânico, declarou que se sentia uma "prisioneira", e o chefe, ao final do expediente, chamava quem, para ele, tivesse apresentado comportamento "fora do normal". 160

A organização repetitiva e monótona do trabalho também cria a insatisfação, porta de entrada para a doença, "uma encruzilhada que se abre para as descompensações mentais ou doenças somáticas", no dizer de Christophe Dejours. ${ }^{161}$

Nas empresas estruturadas de forma automatizada, lembra Nadia Demoliner Lacerda, normalmente voltadas ao fabrico de veículos ou de equipamentos e componentes eletrônicos, verificam-se os principais impactos da monotonia e da repetitividade das tarefas, muito embora tais aspectos também possam ser encontrados em outras atividades. $^{162}$

Além disso, ressalte-se que a introdução das novas tecnologias modifica as responsabilidades dos trabalhadores, os requisitos de qualificação, o conteúdo do trabalho, as cargas físicas e mentais, bem como as relações sociais no trabalho.

\footnotetext{
${ }^{159}$ Pressão fatal. Revista do Brasil, n. 52, p. 20, out. 2010.

${ }^{160}$ Disponível em: <http://www.tst.jus.br/noticias>. Acesso em: 24 set. 2012.

${ }^{161}$ DEJOURS, Christophe. A loucura do trabalho. São Paulo: Cortez - Oboré, 1988. p. 133.

162 LACERDA, Nadia Demoliner. Segurança e saúde do trabalhador: para onde vamos? O debate nacional sobre a concepção preventiva do novo seguro de acidente. São Paulo: LTr, 2011. p. 30.
} 
A perda do controle sobre a cadência de trabalho, com sua frequente intensificação, tem gerado um aumento de queixas de fadiga, estresse, doenças psicossomáticas e distúrbios osteomusculares relacionados ao trabalho (DORT), entre outros. $^{163}$

Pesquisa recente estuda os workaholics, apontando que aqueles que têm compulsão pelo trabalho agem assim em decorrência de determinados traços da personalidade, como ambição desmedida ou comportamento obsessivo; trabalham para reduzir sentimentos como culpa ou ansiedade. No entanto, as novas tecnologias também impulsionam este tipo de comportamento, pois com a internet móvel, com os e-mails e documentos de trabalho na palma da mão, e a qualquer momento, separar o tempo para si do tempo para o trabalho é cada vez mais raro para a maioria dos profissionais. O resultado é ganho de peso, alterações de humor, irritabilidade. ${ }^{164}$

Consequência das condições de trabalho, encontrada na literatura japonesa por força das ocorrências no Japão, o karoshi é o termo que se refere à morte súbita no trabalho, provocada pelo ritmo e intensidade que decorrem da busca incessante do aumento da produtividade. Essa tragédia também ocorre no Brasil: no período de 2004-2005, 13 trabalhadores faleceram nos canaviais paulistas em razão do excessivo esforço imposto pelas empresas do setor sucroalcooleiro. Todos os mortos eram migrantes temporários, exceto um deles; todos eram homens, exceto uma mulher. Os sintomas registrados se referiam a dores de cabeça, fortes cãibras seguidas de desmaios e, finalmente, parada cardiorrespiratória. $^{165}$

Ada Ávila Assunção e Francisco Antunes Lima afirmam que no Brasil ainda há a supremacia da produção e do lucro em curto prazo, em relação à segurança. Sustentam que as melhorias das condições de trabalho deveriam ser consideradas como um investimento produtivo, e não como um custo que apenas onera a produção.

\footnotetext{
${ }^{163}$ MINAYO GOMEZ, Carlos et al. (Org.). Saúde do trabalhador na sociedade brasileira contemporânea. Rio de Janeiro: Fiocruz, 2011. p. 147-148.

${ }^{164}$ Meu nome é trabalho. Folha de S. Paulo, caderno Negócios e carreiras, 7 out. 2012, p. 6-7.

165 SILVA, Maria Aparecida de Morais et al. Do karoshi no Japão à birôla no Brasil: as faces do trabalho no capitalismo mundializado. Revista Nera, ano 9, n. 8, jan.-jun. 2006. Disponível em: $<$ http://www2.fct.unesp.br/nera/revistas/08/Silva.PDF>. Acesso em: 9 out. 2012.
} 
Prosseguem dizendo que:

A análise de custos $x$ benefícios não aumenta a segurança, ao contrário, coloca-lhe peias, pois assume como pressuposto que as ações voltadas à segurança devem se pautar pelos cálculos de retorno financeiro. [...]

Assim, dependendo do custo da mão de obra, quando ela é muito barata, é mais vantajoso, é tolerável, segundo uma perspectiva puramente econômica, conviver comum número elevado de acidentes: considera-se "natural" convivermos com piores condições de trabalho no Brasil do que na Europa. ${ }^{166}$

Admitem os autores que o risco é parte inerente da atividade humana, e ainda que ele seja o preço que se paga ao desenvolvimento da própria capacidade humana de tornar a vida mais confortável e mais segura. No entanto,tal argumentação abstrata não justifica a distribuição desigual dos riscos e das responsabilidades entre trabalhadores e tomadores de decisão. Dizem que este é o ponto falho da ideologia do "risco social", que tolera os acidentes em nome do progresso econômico. ${ }^{167}$

Observe-se que o fraco resultado da economia brasileira no segundo trimestre de 2012 sepultou a permanência do Brasil como a sexta maior economia do mundo, posto que havia sido atingido no início do ano com o anúncio dos resultados econômicos de 2011; , ainda que o País esteja de volta à sétima posição, está no grupo das maiores economias mundiais, pois vem atrás de Grã-Bretanha, França, Alemanha, Japão, China e Estados Unidos. $^{168}$

Por isso, é absolutamente insustentável que continuem eclodindo doenças de origem ocupacional e acidentes do trabalho, em índices alarmantes e intoleráveis, em um país que se encontra entre as economias mais desenvolvidas do globo.

\footnotetext{
${ }^{166}$ ASSUNÇÃO, Ada Ávila; ANTUNES LIMA, Francisco de Paula. A contribuição da ergonomia para a identificação, redução e eliminação da nocividade do trabalho. In: MENDES, René et al. Patologia do trabalho. São Paulo: Atheneu, 2005. p. 1774.

${ }^{167}$ Idem, ibidem.

${ }^{168}$ Disponível em: <http://veja.abril.com.br/noticia/economia/pib-fraco-faz-brasil-perder-posto-de-6aeconomia-do-mundo>. Acesso em: 9 out. 2012.
} 


\subsubsection{Custo social e custo previdenciário}

Os acidentes de trabalho mataram 464 pessoas no Estado de São Paulo ao longo de 2011, uma média de mais de um caso por dia. Segundo o balanço da Divisão de Saúde do Trabalhador da Vigilância Sanitária Estadual, foram notificados 55,4 mil acidentes ocupacionais ao longo de todo o ano passado.

As principais causas das mortes durante o trabalho foram os acidentes de trânsito, as quedas de edifícios, a exposição à corrente elétrica e o impacto causado por objetos lançados, projetados ou em queda.

Do total de acidentes notificados, $48 \%$ foram classificados como graves, fatais ou em menores de 18 anos. Cerca de 25,5\% das intoxicações têm causas externas e 20,1\% foram provocadas por materiais biológicos. Há ainda registros de câncer relacionado ao trabalho, transtorno mental e perda auditiva induzida por ruído. De acordo com a diretoria da Divisão de Saúde do Trabalhador, a maior parte das fatalidades poderia ter sido evitada, pois praticamente todos os acidentes aconteceram em situações previsíveis e preveníveis. ${ }^{169}$

Os acidentes de trabalho são evitáveis e causam um grande impacto sobre a produtividade e a economia, além de grande sofrimento para a sociedade. Segundo a Organização Internacional do Trabalho (OIT), ocorrem cerca de 270 milhões de acidentes de trabalho e aproximadamente dois milhões de mortes por ano em todo o mundo, que, por serem potencialmente evitáveis, expressam negligência e injustiça social. Os custos dos acidentes de trabalho são raramente contabilizados, mesmo em países com importantes avanços no campo da prevenção. Estima-se que 4\% do Produto Interno Bruto (PIB) seja perdido por doenças e agravos ocupacionais, o que pode aumentar para 10\% quando se trata de países em desenvolvimento. No Brasil, com base no PIB do ano 2002, essas estimativas de perda ficariam entre US\$21.899.480 e US\$54.748.700, refletindo baixa efetividade das políticas e programas de prevenção de agravos à saúde no trabalho. Tais valores limitam-se aos custos econômicos e não incluem aqueles decorrentes dos impactos emocionais e familiares, dificilmente mensuráveis. Estudos sobre estimativas científicas dos custos dos acidentes de

\footnotetext{
${ }^{169}$ Disponível em: <http://www.redebrasilatual.com.br/temas/trabalho/2012/05/acidentes-de-trabalhomataram-464-pessoas-no-estado-de-sao-paulo-em-2011>. Acesso em: 7 out. 2012.
} 
trabalho têm se multiplicado nos últimos anos. Isso se deve ao desenvolvimento da área da economia da saúde, e a estreita relação entre trabalho e economia, seja pelos fatores de risco para os acidentes, seja pelos seus efeitos sobre a capacidade produtiva. ${ }^{170}$

Sebastião Geraldo de Oliveira expôs no 24. ${ }^{\circ}$ Encontro Presencial do Fórum de Acidentes do Trabalho, realizado na Faculdade de Saúde Pública da Universidade de São Paulo, em junho de 2011, o quadro abaixo, sistematizado com base nos índices da Previdência Social, em que consta o número de ocorrências de acidentes do trabalho e de afastamentos por doenças ocupacionais entre os anos de 2004 e 2009. Da análise desses dados constata-se que vinha ocorrendo uma diminuição do número de casos de invalidez temporária e permanente, bem como dos casos fatais, até o ano de 2007. A partir de 2008 o número volta a crescer, o que aponta que, com a vigência da Lei n. ${ }^{\circ} 11.430$, de 26 de dezembro de 2006, que instituiu o nexo técnico epidemiológico entre o trabalho e o agravo, o número de doenças ocupacionais e acidentes de trabalho aumentou:

\begin{tabular}{|c|c|c|c|c|c|}
\hline \multicolumn{6}{|c|}{$\begin{array}{l}\text { EXCLUÍDOS DO MUNDO DO TRABALHO NO BRASIL POR } \\
\text { ACIDENTE DO TRABALHO OU DOENÇA OCUPACIONAL }\end{array}$} \\
\hline ANO & $\begin{array}{l}\text { INVAUDEZ } \\
\text { TEMPORÁRIA: } \\
\text { + DE15 DIAS }\end{array}$ & $\begin{array}{l}\text { INVAUDEZ } \\
\text { PERMANENTE }\end{array}$ & MORIES & SOMA & $\begin{array}{l}\text { EXCLUÍDOS } \\
\text { POR DIA }\end{array}$ \\
\hline 2005 & 163.052 & 14.371 & 2.766 & 17.137 & 47 \\
\hline 2006 & 149.944 & 9.203 & 2.798 & 12.001 & 33 \\
\hline 2007 & 269.752 & 9.389 & 2.845 & 12.234 & 34 \\
\hline 2008 & 335.609 & 13.096 & 2.817 & 15.913 & 44 \\
\hline 2009 & 320.378 & 13.047 & 2.496 & 15.543 & 43 \\
\hline
\end{tabular}

${ }^{170}$ SANTANA, Vilma Sousa et al. Acidentes de trabalho: custos previdenciários e dias de trabalho perdidos. Revista Saúde Pública, São Paulo, v. 40, n. 6, 2006.

${ }^{171}$ OLIVEIRA, Sebastião Geraldo de. Aspectos atuais da responsabilidade jurídica em acidentes do trabalho. 24. ${ }^{\circ}$ Encontro Presencial do Fórum Acidentes do Trabalho: análise, prevenção e aspectos associados. São Paulo: Faculdade de Saúde Pública da Universidade de São Paulo, jun. 2011. Disponível em: <http://www.moodle.fmb.unesp.br/mod/resource/view.php?id=5334>. Acesso em: 25 jun. 2011. 
Como consta do sítio do Ministério da Previdência e Assistência Social (MPAS):

Em 2009 foram registrados 723.452 acidentes e doenças do trabalho, entre os trabalhadores assegurados da Previdência Social. Observem que este número, que já é alarmante, não inclui os trabalhadores autônomos (contribuintes individuais) e as empregadas domésticas. Estes eventos provocam enorme impacto social, econômico e sobre a saúde pública no Brasil. Entre esses registros contabilizou-se 17.693 doenças relacionadas ao trabalho, e parte destes acidentes e doenças tiveram como consequência o afastamento das atividades de 623.026 trabalhadores devido à incapacidade temporária (302.648 até 15 dias e 320.378 com tempo de afastamento superior a 15 dias), 13.047 trabalhadores por incapacidade permanente, e o óbito de 2.496 cidadãos. Para termos uma noção da importância do tema saúde e segurança ocupacional basta observar que no Brasil, em 2009, ocorreu cerca de 1 morte a cada 3,5 horas, motivada pelo risco decorrente dos fatores ambientais do trabalho e ainda cerca de 83 acidentes e doenças do trabalho reconhecidos a cada 1 hora na jornada diária. Em 2009 observamos uma média de 43 trabalhadores/dia que não mais retornaram ao trabalho devido a invalidez ou morte.

Se considerarmos exclusivamente o pagamento, pelo INSS, dos benefícios devido a acidentes e doenças do trabalho somado ao pagamento das aposentadorias especiais decorrentes das condições ambientais do trabalho em 2009, encontraremos um valor da ordem de R\$ 14,20 bilhões/ano. Se adicionarmos despesas como o custo operacional do INSS mais as despesas na área da saúde e afins o custo Brasil atinge valor da ordem de R \$ 56,80 bilhões (Fonte: Previsão MPS). A dimensão dessas cifras apresenta a premência na adoção de políticas públicas voltadas à prevenção e proteção contra os riscos relativos às atividades laborais. Muito além dos valores pagos, a quantidade de casos, assim como a gravidade geralmente apresentada como consequência dos acidentes do trabalho e doenças profissionais, ratificam a necessidade emergencial de construção de políticas públicas e implementação de ações para alterar esse cenário. ${ }^{172}$

Assim, os cofres públicos, por meio do sistema de Seguridade Social, arcam com as despesas com tratamentos médicos, reabilitações e benefícios. Ressalte-se que muitas vezes os acidentes do trabalho são fatais, em que falece o arrimo de família, e, mesmo que os dispêndios com pensões por morte sejam assumidos pela Previdência Social, nunca será suficiente para evitar o desamparo das famílias e reparar o custo social decorrente das mortes de seus membros.

Como a Seguridade Social assume os ônus dessa verdadeira tragédia, quem em última instância está sendo onerado é o contribuinte. É preciso dar um basta em tal

\footnotetext{
${ }^{172}$ Disponível em: <http://www.mpas.gov.br/conteudoDinamico.php?id=39>. Acesso em: 9 out. 2012.
} 
situação, de modo que os responsáveis pelas doenças e acidentes do trabalho sejam efetivamente onerados com o custo social, de tal forma que esse ônus tenha efeito pedagógico para que as moléstias e sinistros decorrentes do trabalho sejam de fato evitados. 


\section{CAPÍTULO 2}

\section{O TRABALHO E OS DIREITOS FUNDAMENTAIS. DO DIREITO AO MEIO AMBIENTE DO TRABALHO EQUILIBRADO}

\subsection{Princípios e direitos fundamentais do trabalho nos planos internacional e nacional}

$\mathrm{Na}$ história da humanidade, marcada por guerras e conquistas que submetiam o povo conquistado à vontade do conquistador, constata-se a fragilidade da condição humana, subjugada à vontade do detentor do poder.

Afirma o Prof. Antonio Rodrigues de Freitas Jr. que não é demasiado admitir que os direitos humanos fundamentais nasceram se não contra o Estado como entidade abstrata, ao menos seguramente como negação dos poderes absolutos do "Príncipe", vale dizer, como limitação e contenção à ação daquele ou daqueles que se encontram no exercício dos poderes coercitivos do Estado. Destaca esse autor que em um estágio posterior incorporam-se aos chamados direitos humanos fundamentais outras figuras que, por sua natureza menos constritiva, absenteísta e negativa, conferiam ao Estado o dever de prestação positiva. Nessa segunda projeção desses direitos, caberia ao Estado não apenas abster-se de excessos lesivos ao patrimônio jurídico dos súditos, como também, mediante ações promocionais e distributivas, assegurar-lhes um mínimo de proteção social apta a lhes preservar a dignidade humana. ${ }^{173}$

$\mathrm{Na}$ fase de transição entre a Idade Média e a Idade Contemporânea, a valorização do comércio e do capital constituiu a base sobre a qual se desenvolveu o sistema capitalista. Com a valorização das relações comerciais e o crescimento do capital, o trabalho humano passou a ser a principal fonte de criação de riquezas, pois a produção dependia do labor humano.

\footnotetext{
${ }^{173}$ FREITAS JR., Antonio Rodrigues de. Direitos sociais e eficácia horizontal dos direitos fundamentais: possíveis consequências práticas para o exercício do poder disciplinar do empregador. In: SÉGUIN, Elida; FIGUEIREDO, Guilherme José Purvin de (Coord.). Meio ambiente do trabalho. Rio de Janeiro: GZ Verde Editora, 2010. p. 115-116.
} 
A Era das Revoluções, iniciada com a independência dos Estados Unidos (1776), seguida pela Revolução Industrial (de 1760 a cerca de 1850) e a Revolução Francesa (1789), pôs fim ao Antigo Regime e à Idade Moderna. Ressalte-se, no entanto, que o principal movimento que arquitetou ideias capazes de derrubar o Antigo Regime foi o Iluminismo. Os ideais iluministas de igualdade, liberdade e fraternidade, lemas da Revolução Francesa, trouxeram uma nova visão de relação entre o Estado, até então despótico e absolutista, e o cidadão. ${ }^{174}$

A evolução dos direitos fundamentais é demonstrada pelo jurista Karel Vasak com base no lema da Revolução Francesa, "Liberdade, Igualdade e Fraternidade". O referido jurista desenvolveu a doutrina da "geração dos direitos fundamentais", segundo a qual a primeira geração é a dos direitos civis e políticos, fundamentados na liberdade; a segunda geração é a dos direitos econômicos, sociais e culturais, baseados na igualdade; os de terceira geração seriam os direitos de solidariedade, coroando a tríade com a fraternidade. ${ }^{175}$

Paulo Bonavides ensina que Vasak identificou cinco direitos fundamentais de terceira geração: o direito ao desenvolvimento, o direito à paz, o direito ao meio ambiente, o direito de propriedade sobre o patrimônio comum da humanidade e o direito de comunicação. $^{176}$

O termo "geração" recebe críticas, pois sugere exclusão da geração passada, na medida em que surge a seguinte; Fábio Fernandes afirma que a expressão "família de direitos humanos", cunhada pelo jurista argentino Genaro Carrió, é mais adequada, uma vez que a relação entre os mesmos não é de exclusão, mas de complementaridade. ${ }^{177}$

\footnotetext{
${ }^{174}$ STUCHI, Victor Hugo Nazário. O trabalho penoso e a dignidade da pessoa humana. In: PIOVESAN, Flávia; CARVALHO, Luciana Paula Vaz de (Coord.). Direitos humanos e direito do trabalho. São Paulo: Atlas, 2010. p. 225.

175 PIOVESAN, Flávia. Temas de direitos humanos. São Paulo: Max Limonad, 1998. p. 28.

${ }^{176}$ BONAVIDES, Paulo. Curso de direito constitucional. São Paulo: Malheiros, 2000. p. 523.

${ }^{177}$ FERNANDES, Fábio de Assis F. Meio ambiente do trabalho e a dignidade do cidadão trabalhador. In: In: PIOVESAN, Flávia; CARVALHO, Luciana Paula Vaz de (Coord.). Direitos humanos e direito do trabalho. São Paulo: Atlas, 2010. p. 305.
} 
A despeito da questão terminológica, importa dizer que a melhor compreensão no tocante ao tema é da ideia de harmonização, de complemento. Nesse sentido, pode-se afirmar que o direito ao meio ambiente sadio, de terceira geração, não eliminou o direito de propriedade; exige-se que este último seja exercido em consonância com a conservação dos recursos naturais, alargando o sentido da função social da propriedade. E nessa esteira, como destaca Maria Isabel Cueva Moraes, correm em linhas paralelas os direitos ao desenvolvimento e ao meio ambiente saudável como patamar digno de convivência. ${ }^{178}$

Cumpre ressaltar no plano nacional o direito fundamental consignado no artigo 5. ${ }^{\circ}$, caput, da Constituição Federal: o direito à vida; e para que seja assegurada a sua inviolabilidade, bem como seu pleno exercício, é preciso que sejam observados dois outros direitos, pressupostos para sua existência: a saúde e o trabalho, sob pena de inviabilizar o gozo daquele direito fundamental, diante do liame inseparável existente entre os três.

Não é demais salientar que o "direito à vida" pressupõe que a vida humana não seja "qualquer tipo de vida" ou "sobrevida", e exige-se, segundo Fábio Fernandes,

[...] a vida vivida, ou, para citarmos o texto na forma vazada: "sadia qualidade de vida" para cuja concretização torna-se imprescindível estar presente essa qualidade, também no local onde ocorre uma das principais manifestações do homem com o seu meio, dando-se eficácia aos ditames constitucionais que fixam como direito fundamental a vida (arts. $1 .^{\circ}$, III e $5^{\circ}$ ) e como direitos sociais fundamentais, a saúde e o trabalho (art. $\left.6 .^{\circ}\right) .{ }^{179}$

É sabido que o crescimento econômico e a evolução tecnológica, por si sós, não asseguram o progresso social, a erradicação da pobreza e o respeito aos direitos humanos.

Pode-se afirmar que somente depois da Declaração Universal dos Direitos Humanos, aprovada pela Assembleia-Geral das Nações Unidas, em 10 de dezembro de 1948, após a Segunda Grande Guerra, os direitos humanos foram demarcados como universais. Nesse sentido, sustenta Flávia Piovesan, a Declaração de 1948 demarca a concepção contemporânea dos direitos humanos, por fixar a ideia de que estes "são

\footnotetext{
${ }^{178}$ MORAES, Maria Isabel Cueva. A negociação coletiva ambiental trabalhista e seus frutos. 2008. Dissertação (Mestrado) - Faculdade de Direito da USP, São Paulo, p. 18.

${ }^{179}$ FERNANDES, Fábio. Meio ambiente geral e meio ambiente do trabalho: uma visão sistêmica. São Paulo: LTr, 2009. p. 34.
} 
universais, inerentes à condição de pessoa e não relativos às peculiaridades sociais e culturais de determinada sociedade, seja por incluir em seu elenco não só direitos civis e políticos, mas também direitos sociais, econômicos e culturais", ${ }^{180}$

A universalidade dos direitos humanos, no entanto, não é uma unanimidade, como observa José Cláudio Monteiro de Brito Filho, destacando que, ao lado do que se convencionou chamar de "universalismo", tem-se o que se denomina "relativismo cultural", concepção segundo a qual a diversidade de culturas determinaria a impossibilidade de ter uma ordem mundial a respeito desse conjunto mínimo que se denomina Direitos Humanos. ${ }^{181}$

Esse autor firma posição no sentido da necessidade de haver uma ordem mundial a respeito dos direitos humanos, com determinados direitos e valores de observância obrigatória em todo o mundo. Ressalta que nem todos os direitos previstos na Declaração Universal devem ser tidos como integrantes do conjunto mínimo de direitos definidos como direitos humanos. Nesse sentido, destaca o direito de propriedade: não haveria ofensa aos direitos humanos se determinado Estado abolisse tal direito, como já ocorreu. $\mathrm{E}$ conclui salientando que o caminho não é o relativismo, tampouco o universalismo. Há que se estabelecer uma pauta mínima, que possa ser considerada como efetivamente universal, necessária à preservação da dignidade da pessoa humana. ${ }^{182}$

Com o objetivo de manter o vínculo entre progresso social e crescimento econômico, a Organização Internacional do Trabalho (OIT), elevou à condição de princípios fundamentais os chamados core labor standards (ou direitos fundamentais do trabalho), assim definidos pela Conferência anual e Declaração da OIT de 1998: os direitos à negociação coletiva, liberdade de associação e liberdade sindical; eliminação da discriminação no local de trabalho; abolição do trabalho infantil e eliminação do trabalho forçado. Consta dos "considerandos" dessa Declaração que a garantia dos princípios e

\footnotetext{
${ }^{180}$ PIOVESAN, Flávia. A Constituição brasileira de 1988 e os tratados internacionais de proteção dos direitos humanos. In: MARCílLIO, Maria Luisa e o (Coord.). Cultura dos direitos humanos. São Paulo: LTr, 1998. p. 139.

${ }^{181}$ BRITO FILHO, José Cláudio Monteiro de. Trabalho decente: análise jurídica da exploração, trabalho escravo e outras formas de trabalho indigno. São Paulo: LTr, 2010. p. 31.

${ }^{182}$ Idem, ibidem, p. 32-33.
} 
direitos fundamentais no trabalho reveste uma importância e um significado especiais ao assegurar aos próprios interessados a possibilidade de reivindicar livremente e em igualdade de oportunidades uma participação justa nas riquezas a cuja criação têm contribuído, assim como a de desenvolver plenamente seu potencial humano.

E nessa esteira a OIT define como meta central o Trabalho Decente, que é o trabalho produtivo e adequadamente remunerado, exercido em condições de liberdade, equidade e segurança, sem quaisquer formas de discriminação, e capaz de garantir uma vida digna a todas as pessoas que vivem de seu trabalho; nessa concepção estão inseridos vários standards relativos ao tema de saúde e segurança no trabalho.

Os quatro eixos centrais da Agenda do Trabalho Decente são: a criação de empregos e meios de vida sustentáveis; garantia de direitos no trabalho; extensão da proteção social, para promover a inclusão e produtividade, assegurando que mulheres e homens desfrutem de condições de trabalho seguras, com tempo livre e descanso adequado, e com compensação adequada em caso de perda de renda ou redução; acesso a cuidados de saúde apropriados; além disso, há que se assegurar a promoção ao diálogo social, de forma a respeitar os princípios e direitos fundamentais no trabalho, expressos na Declaração dos Direitos e Princípios Fundamentais no Trabalho da OIT, adotada em 1998. ${ }^{183}$

\subsection{Princípio da dignidade da pessoa humana, a ordem econômica e o valor social do trabalho}

Afirma-se como possível a existência de um fundamento único para os Direitos Humanos, cabendo questionar qual a razão da opção pela dignidade. Fábio Konder Comparato responde tal indagação, quando explicita que o valor do direito decorre daquele que o criou, o homem. Portanto, o fundamento não é outro senão o próprio homem, "considerado em sua dignidade substancial de pessoa". ${ }^{184}$

\footnotetext{
${ }^{183}$ Disponível em: <http://www.ilo.org/global/about-the-ilo/decent-work-agenda/lang-en/index/htm>. Acesso em: 16 jul. 2012.

${ }^{184}$ COMPARATO, Fábio Konder. Fundamento dos direitos humanos. In: MARCILIO, Maria Luiza e o (Coord.). Cultura dos direitos humanos. São Paulo: LTr, 1998. p. 60.
} 
Depreende-se das lições de Comparato que a dignidade é o traço distintivo entre o homem e os demais seres vivos.

E o conceito de dignidade de pessoa humana é extraído da obra de Ingo Wolfgang Sarlet, que a define como

[...] a qualidade intrínseca e distintiva de cada ser humano que o faz merecedor do mesmo respeito e consideração por parte do Estado e da comunidade, implicando, nesse sentido, um complexo de direitos e deveres fundamentais que assegurem a pessoa tanto contra todo e qualquer ato de cunho degradante e desumano, como venham a the garantir as condições existenciais mínimas para uma vida saudável, além de propiciar e promover sua participação ativa e corresponsável nos destinos da própria existência e da vida em comunhão com os demais seres humanos. ${ }^{185}$

Nessa perspectiva, Sarlet afirma que a dignidade, "como qualidade intrínseca da pessoa humana, é irrenunciável e inalienável, constituindo elemento que qualifica o ser humano como tal e dele não pode ser destacado". ${ }^{186}$

A concepção de dignidade tem várias explicações; ilustramos com as ideias fundadas no Cristianismo e em Kant.

No Cristianismo, decorre da atribuição dada por Deus; o homem é o único ser criado à imagem e semelhança de seu Criador. $\mathrm{O}$ primeiro problema em aceitar a dignidade de acordo nessa perspectiva é que ela somente pode ser comprovada por meio da fé, situando-se, portanto, em um plano metafísico. O segundo problema é que um de seus componentes, a igualdade, é afetado, na concepção cristã, por ideias como a da resignação; assim, a igualdade seria alcançada em outro mundo, que não o terreno.

Sob a ótica kantiana, no reino das finalidades humanas, tudo ou tem um preço ou tem dignidade. ${ }^{187}$ Assim, a dignidade não é passível de troca ou substituição. O homem, ser

\footnotetext{
185 SARLET, Ingo Wolfgang. Dignidade da pessoa humana e direitos fundamentais na Constituição Federal de 1988. 2. ed. rev. e ampl. Porto Alegre: Livraria do Advogado, 2002. p. 62.

${ }^{186}$ Idem, ibiem, p. 41.

187 "No reino dos fins tudo tem um preço ou uma dignidade. Quando uma coisa tem um preço, pode-se por em vez dela qualquer outra ou equivalente; mas quando uma coisa está acima de todo o preço, e portanto
} 
racional e dotado de autonomia, capaz de fazer suas escolhas, é o único portador de dignidade. O homem não pode ser considerado como outra coisa senão um fim em si mesmo.

O reconhecimento da dignidade conduz ao entendimento de que nela há, de um lado, o poder de fazer escolhas, de exercitar a autonomia, e, de outro, o direito de ter respeito mínimo por parte do Estado e de toda a comunidade. Nesse sentido, a previsão do artigo $1 .^{\circ}$ da Declaração Universal dos Direitos Humanos ${ }^{188}$ que, ressalta José Cláudio Monteiro de Brito Filho, revela que a dignidade deve produzir efeitos no plano material, como vetor que impõe obrigações ao Estado e a toda a sociedade. ${ }^{189}$

Maria Celina Bodin de Moraes $^{190}$ refere os quatro princípios jurídicos fundamentais que, vinculados a um conjunto de direitos fundamentais, são concretizadores do substrato material da dignidade: 1. o princípio da igualdade, que veda toda e qualquer discriminação arbitrária e fundada nas qualidades da pessoa; 2. o princípio da liberdade, que assegura a autonomia ética e, portanto, a capacidade para a liberdade pessoal; 3. o princípio da integridade física e moral (inclusive a garantia de um conjunto de prestações materiais que asseguram uma vida com dignidade); 4. e o princípio da solidariedade, relacionado à garantia e promoção da coexistência humana em suas diferentes manifestações.

Essa autora ressalta que a Constituição Federal, no artigo 1. ${ }^{\circ}$, III atribuiu ao princípio da dignidade da pessoa humana o valor supremo de alicerce da ordem jurídica democrática. Com efeito, da mesma forma que Kant estabelecera para a ordem moral, é na dignidade humana que a ordem jurídica (democrática) se apoia e constitui-se. ${ }^{191}$

não permite equivalente, então ela tem dignidade" (KANT, Immanuel. Fundamentação da metafísica dos costumes. Lisboa: Edições 70, 2003. p. 77).

188 "Todos os homens nascem livres e iguais em dignidade e direitos. São dotados de razão e consciência e devem agir em relação uns aos outros com espírito de fraternidade."

${ }^{189}$ BRITO FILHO, José Cláudio Monteiro de. Trabalho decente: análise jurídica da exploração, trabalho escravo e outras formas de trabalho indigno. São Paulo: LTr, 2010. p. 38.

${ }^{190}$ MORAES, Maria Celina Bodin de. O conceito de dignidade humana: substrato axiológico e conteúdo normativo. In: SARLET, Ingo Wolfgang (Org.). Constituição, direitos fundamentais e direito privado. Porto Alegre: Livraria do Advogado, 2006. p. 116-143.

${ }^{191}$ Idem, ibidem, p. 117. 
E, ao tratar dos direitos do homem, merecem destaque os direitos dos trabalhadores, que se encontram nos chamados Direitos Humanos de segunda geração, os chamados direitos econômicos e sociais.

Os direitos sociais foram assegurados pela Constituição Federal, no Capítulo II, artigo $6 .^{\circ}$, abrangendo o direito à educação, à saúde, ao trabalho, à moradia, ao lazer, à segurança, à previdência social, à proteção à maternidade e à infância e à assistência aos desamparados.

Logo, assegurar o direito ao trabalho e em condições decentes é dar concretude ao princípio da dignidade da pessoa humana. E nesse sentido deve orientar a legislação, como ensina Mario De la Cueva:

[...] tem o direito do trabalho como finalidade primeira proteger a saúde e a vida do trabalhador e garantir-lhe um nível de vida compatível com a dignidade humana. E, se este é o seu propósito, é natural que, estando condicionada à realização desse objetivo pelo conteúdo da relação de trabalho, tivesse a lei o cuidado de fixá-lo de modo imperativo. ${ }^{192}$

Assim, recebem tutela especial do nosso ordenamento jurídico a dignidade da pessoa humana, bem como os valores sociais do trabalho e da livre-iniciativa, princípios fundamentais da República, consignados no artigo 1. ${ }^{\circ}$ da Constituição Federal.

Nesse passo, o valor social do trabalho foi erigido pela Constituição do Brasil como princípio fundamental do Estado Democrático de Direito, ao lado da livre-iniciativa. Esses dois valores, apesar de estarem em constante conflito, fruto da sua bipolaridade, no sentido empregado pelo Prof. Miguel Reale, não se excluem, ao contrário, tendem ao equilíbrio e à concretização, por meio da mútua implicação, devendo o intérprete ter sempre em mente que tais valores não serão jamais alcançados em sua plenitude.

Dessa forma, quando há um contrato de trabalho, firmado e executado como decorrência da livre pactuação dos implicados, cujos direitos e obrigações estão insertos nas normas laborais, dentre eles a inegável possibilidade de resolução contratual a qualquer dos contratantes, como resultado da liberdade de agir garantida também

${ }^{192}$ DE LA CUEVA, Mario. Derecho mexicano del trabajo. 1949, v. 1, p. 495. 
constitucionalmente, há que se ter presente que essa liberdade de agir deverá ser aferida dentro da ótica de valoração dos bens da vida, que merecem tutela e precedência de tutela.

Assim, respeitada a autonomia da vontade, esta não é absoluta, na medida em que deve observar as normas de ordem pública. Aqui cumpre destacar que os princípios civilistas seguem a nova ótica imposta aos contratantes pelo Código Civil de 2002: “Art. 421. A liberdade de contratar será exercida em razão e nos limites da função social do contrato".

Portanto, o direito ao trabalho, quando premissa do direito à vida, deve ser resguardado. Pertinente citar aqui o Enunciado 23 aprovado na Jornada de Direito Civil, promovida pelo Centro de Estudos Judiciários do Conselho da Justiça Federal, ${ }^{193}$ a saber:

Enunciado 23. A função social do contrato prevista no art. 421 do novo Código Civil não elimina o princípio da autonomia contratual, mas atenua ou reduz o alcance desse princípio, quando presentes interesses metaindividuais ou interesse individual relativo à dignidade da pessoa humana.

Aqui, adequada a menção ao Enunciado 22, que dá lastro ao anterior: "Enunciado 22. A função social do contrato prevista no art. 421 do novo Código Civil constitui cláusula geral, que reforça o princípio de conservação do contrato, assegurando trocas úteis e justas".

Nesse sentido, oportuno transcrever ensinamento de Enoque Ribeiro dos Santos:

[...] Se nos idos da Revolução Industrial dos séculos XVIII e XIX foi necessária a intervenção do Estado para abrandar os desequilíbrios existentes nos contratos de trabalho e retornar ao equilíbrio maculado pela desigualdade de fato, em face da aceitação da doutrina clássica do individualismo econômico, em que a força obrigatória (pacta sunt servanda) dos contratos repousava em conceitos amplos de liberdade e igualdade, que não se harmonizavam no campo econômico, com o advento do novo Código Civil outro paradigma está sendo rompido: o Estado acaba de reconhecer a prevalência do social sobre o individual e busca, por meio de normas de ordem pública e cogentes, amparar o hipossuficiente em face do poder econômico do mais forte.

193 Jornadas de Direito Civil. Organização Ministro Ruy Rosado de Aguiar Jr. Brasília: CJF, 2007. 
Assim, ao mais fraco deve ser conferido um standard mínimo de Direitos e de proteção jurídica que possibilite o mínimo indispensável a uma vida digna. E esse standard mínimo de Direitos é conferido pela função social do contrato, que vem estampada no novo Código em inúmeras regras que reprimem os atos não socialmente desejáveis e que objetivam prevenir e punir atos prejudiciais. $[\ldots]^{194}$

Cumpre observar aqui que a ordem econômica na Constituição de 1988 define opção por um sistema, o sistema capitalista, como afirma Eros Grau. ${ }^{195}$ No entanto, isso não impede, em absoluto, que a exploração da atividade econômica deva ser analisada pela ótica da função social da empresa, e no direito à existência digna, conforme princípio adotado pela própria Constituição Federal, no artigo 170, inciso III:

A ordem econômica, fundada na valorização do trabalho humano e na livre iniciativa, tem por fim assegurar a todos existência digna, conforme os ditames da justiça social, observados os seguintes princípios:

$[\ldots]$

III - função social da propriedade.

Assim, qualquer meio de produção deve visar à valorização do trabalho humano de forma a propiciar condições de vida digna, contribuindo, desse modo, para o bem-estar e distribuição de justiça social, nos termos previstos no artigo 193 da Carta Maior.

\subsection{Princípios ambientais na esfera internacional e à luz da Constituição Federal. Do direito a uma vida saudável}

Princípio, na acepção jurídica e no sentido contido na expressão "princípios fundamentais" do Título I da Constituição Federal, ressalta José Afonso da Silva, reportando-se a Celso Antônio Bandeira de Mello, exprime a noção de "mandamento nuclear de um sistema". 196

Maria Isabel Cueva Moraes salienta que o Direito Ambiental vem se estruturando a partir de princípios que foram recepcionados por nossa ordem jurídica interna, integrando

\footnotetext{
${ }^{194}$ SANTOS, Enoque Ribeiro dos. A função social do contrato, a solidariedade e o pilar da modernidade nas relações de trabalho. São Paulo: LTr, 2003. p. 29.

195 GRAU, Eros Roberto. A ordem econômica na Constituição de 1988. São Paulo: Malheiros, 2010. p. 352.

196 SILVA, José Afonso da. Curso de direito constitucional positivo. São Paulo: Malheiros, 1995. p. 93.
} 
uma política ambiental que, se posta em prática, está apta a possibilitar a preservação do meio ambiente, inclusive do trabalho. ${ }^{197}$ Alguns desses princípios ambientais basilares serão enfocados a seguir.

Ensina Fábio Fernandes que o primeiro documento internacional a tratar do direito do meio ambiente saudável, incluindo o meio ambiente do trabalho, foi o Pacto Internacional dos Direitos Sociais, Econômicos e Culturais (PIDESC), aprovado em 16 de dezembro de 1966 pela Assembleia-Geral das Nações Unidas. Destaca esse autor que o Pacto, no seu artigo 7. , alínea "b", garante "condições de trabalho seguras e higiênicas" e no artigo 12.1 dispõe que os Estados-Partes devem propiciar "o direito de toda pessoa de desfrutar o mais elevado nível possível de saúde física e mental através da melhoria de todos os aspectos de higiene do trabalho e do meio ambiente" (artigo 12.2, "b"). ${ }^{198}$

O princípio do ambiente ecologicamente equilibrado como direito fundamental da pessoa humana foi reconhecido pela Conferência das Nações Unidas sobre Ambiente Humano, pela Declaração de Estocolmo de 1972, conforme o Princípio n. 1:

$\mathrm{O}$ homem tem direito fundamental à liberdade, à igualdade e ao desfrute das condições de vida adequadas em meio ambiente de qualidade tal que lhe permita levar uma vida digna e gozar de bem-estar e tem a solene obrigação de proteger e melhorar o meio ambiente para as gerações presentes e futuras. ${ }^{199}$

Tal direito foi reafirmado na Conferência das Nações Unidas sobre Meio Ambiente e Desenvolvimento, por meio da Declaração do Rio de Janeiro em 1992, que no seu Princípio 1 dispôs que os seres humanos "têm direito a uma vida saudável", conquistando espaço nas Constituições mais modernas, dentre elas a Constituição Federal brasileira, que agasalha tal princípio no reconhecimento do direito à saúde (artigo 196), bem como prevê no seu artigo 225, caput, que todos têm direito ao meio ambiente ecologicamente equilibrado.

\footnotetext{
${ }^{197}$ MORAES, Maria Isabel Cueva. A negociação coletiva ambiental trabalhista e seus frutos. 2008. Dissertação (Mestrado) - Faculdade de Direito da USP, São Paulo, p. 33.

${ }^{198}$ FERNANDES, Fábio. Meio ambiente geral e meio ambiente do trabalho: uma visão sistêmica. São Paulo: LTr, 2009. p. 41.

${ }^{199}$ Idem, ibidem, p. 41.
} 
Cabe lembrar ainda que, antes mesmo da realização da Conferência Rio 92, a OIT já havia adotado o conceito de desenvolvimento sustentável e que, a partir da sua 77. a Conferência Internacional do Trabalho em 1990, reconhece a interação existente entre meio ambiente interno e externo, a partir da percepção de que muitos problemas do meio ambiente externo têm suas causas no ambiente de trabalho. Mais tarde, a OIT elaborou algumas normas que relacionam estes dois temas e tratam de matérias específicas, por exemplo, a Convenção 174 sobre Grandes Acidentes Industriais e a Convenção 136 sobre o Benzeno. ${ }^{200}$

$\mathrm{Na}$ esteira dos padrões da Organização das Nações Unidas (ONU) encontra-se o princípio basilar de nossa Carta Magna, o mandamento de que todos têm direito à vida, com saúde, o que não significa simplesmente inexistência de doenças; a vida deve ser vivida com qualidade, e está assegurado o direito a uma vida digna, com um meio ambiente ecologicamente equilibrado e um meio ambiente do trabalho sadio. E para a consecução desse direito devem ser observadas as normas de proteção à saúde e à segurança do trabalhador, que serão posteriormente examinadas.

\subsubsection{Do meio ambiente do trabalho sadio e equilibrado como direito fundamental}

Norma Sueli Padilha procura uma definição que dê os contornos do meio ambiente no tocante às interações do homem no desempenho das atividades laborativas, considerado o conjunto de elementos que compõem o ambiente onde o trabalho é exercido. Ressalta tratar-se de tema relativamente novo, observando que sob a rubrica de "proteção ao trabalho" abrigam-se vários tópicos no interior das grandes categorias laborais em que estão agrupadas as forças do capital e do trabalho. A autora lastreia-se nas conceituações de várias autores, socorrendo-se, dentre elas, na de Rodolfo de Camargo Mancuso, que aponta o meio ambiente do trabalho como

[...] habitat laboral, isto é, tudo que envolve e condiciona, direta e indiretamente, o local onde o homem obtém os meios para prover o quanto necessário para a sua sobrevivência e desenvolvimento, em equilíbrio com o ecossistema. ${ }^{201}$

\footnotetext{
${ }^{200}$ Disponível em: <www.observatoriosocial.org.br>. Acesso em: 27 abr. 2012.

${ }^{201}$ PADILHA, Norma Sueli. Do meio ambiente do trabalho equilibrado. São Paulo: LTr, 2002. p. 40-41.
} 
Salienta essa autora a essência axiológica do preceito contido na Constituição Federal, em especial ao consignado no artigo 170, relativo à exploração da atividade econômica, que deve ser analisada sob a ótica da função social da empresa, do direito à existência digna e nessa esteira busca definir a natureza jurídica do direito ao meio ambiente do trabalho equilibrado:

Com o intuito de bem situarmos o meio ambiente do trabalho, é importante destacar que, fazendo o tema parte desse contexto do interrelacionamento entre atividade econômica (transformação-domínio), ecologia (recursos naturais) e trabalho (energia), encontra-se, inexoravelmente, no cerne da complexidade de viabilização e coordenação dos objetos tutelados pelos arts. 225 e 170 da Constituição Federal de $1988 .^{202}$

E nesse sentido afirma Sebastião Gerado de Oliveira que

O meio ambiente do trabalho está inserido no meio ambiente geral (art. 200, VIII, da Constituição da República), de modo que é impossível alcançar qualidade de vida sem ter qualidade de trabalho, nem se pode atingir meio ambiente equilibrado e sustentável, ignorando o meio ambiente do trabalho. Nessa perspectiva, a Constituição de 1988 estabeleceu expressamente que a ordem econômica deve observar o princípio de defesa do meio ambiente (art. 170, VI) ${ }^{203}$

O conceito de meio ambiente recebeu definição legal pela primeira vez por meio do artigo 3. ${ }^{\circ}$, inciso I, da Lei 6.938/1991, que instituiu a Política Nacional do Meio Ambiente, e já adotava a diretriz da natureza difusa do bem ambiental, antes do advento da Constituição Federal de 1988, ao definir como "meio ambiente o conjunto de condições, leis, influências e interações de ordem física, química e biológica que permite, abriga e rege a vida em todas as suas formas".

Destaque-se que a Carta de 5 de outubro de 1988 dispõe de um capítulo destinado exclusivamente ao meio ambiente, o Capítulo VI - Do Meio Ambiente, com seu artigo 225, incisos e parágrafos, inserido no Título VIII, Da Ordem Social, que prevê, no caput:

\footnotetext{
${ }^{202}$ PADILHA, Norma Sueli. Do meio ambiente do trabalho equilibrado. São Paulo : LTr, 2002. p. 47.

${ }^{203}$ OLIVEIRA, Sebastião Geraldo de. Proteção jurídica à saúde do trabalhador. 5. ed. São Paulo: LTr, 2010. p. 118
} 
Todos têm direito ao meio ambiente ecologicamente equilibrado, bem de uso comum do povo e essencial à sadia qualidade de vida, impondo-se ao Poder Público e à coletividade o dever de defendê-lo e preservá-lo para as presentes e futuras gerações.

E, como ressalta Raimundo Simão de Melo, para assegurar a efetividade desse direito, incumbe ao Poder Público, como está disposto no $§ 1 .^{\circ}$ desse dispositivo,

[...] exigir, na forma da lei, para instalação de obra ou atividade potencialmente causadora de significativa degradação do meio ambiente, estudo prévio de impacto ambiental, a que se dará publicidade (inciso IV); controlar a produção, a comercialização e o emprego de técnicas, métodos e substâncias que comportem risco para a vida, a qualidade de vida e o meio ambiente (inciso $\mathrm{V}$ ); promover a educação ambiental em todos os níveis de ensino e a conscientização pública para a preservação do ambiente (inciso VI). ${ }^{204}$

Lembra ainda esse autor que as condutas e atividades consideradas lesivas ao meio ambiente sujeitarão os infratores, pessoas físicas ou jurídicas, a sanções penais e administrativas, sem prejuízo da obrigação de reparar os danos causados, como dispõe o $\S$ 3. ${ }^{\circ}$ do mencionado dispositivo constitucional.

Observe-se que as práticas lesivas ao meio ambiente do trabalho, o desrespeito às normas de proteção à saúde dos trabalhadores e suas consequências serão examinados adiante, bem como as formas de reparação. Cumpre salientar que mais importante que tentar a reparação dos danos causados é buscar sua prevenção, objeto da exposição a seguir.

\subsubsection{Princípios da prevenção ou da atuação preventiva e da precaução}

O princípio da prevenção é considerado um megaprincípio ambiental, o princípiomãe da ciência ambiental. ${ }^{205}$

\footnotetext{
${ }^{204}$ MELO, Raimundo Simão de. Direito ambiental do trabalho e a saúde do trabalhador: responsabilidades legais, dano material, dano moral, dano estético, indenização pela perda de uma chance, prescrição. São Paulo: LTr, 2008. p. 43.

${ }^{205}$ Idem, ibidem, p. 44.
} 
Sua previsão normativa antecedeu o advento da Constituição Federal de 1988, pois a Lei 6.938/1991, ao tratar da Política Nacional do Meio Ambiente, previu, dentre seus princípios contidos no artigo $2 .{ }^{\circ}$ :

$$
\begin{aligned}
& \text { III - planejamento e fiscalização do uso dos recursos ambientais; } \\
& \text { IV - proteção dos ecossistemas, com a preservação de áreas } \\
& \text { representativas; } \\
& \text { [...] } \\
& \text { IX - proteção de áreas ameaçadas de degradação. }
\end{aligned}
$$

Trata-se de princípios que exigem, para sua implementação, a adoção de medidas de cunho protecionista, como destaca Fábio Fernandes. ${ }^{206}$

Consciente de que a concreção prática da previsão normativa não seria tarefa fácil ou automática, o legislador inseriu no inciso $\mathrm{X}$ do artigo 2. ${ }^{\circ}$ da Lei da Política Nacional do Meio Ambiente a "educação ambiental a todos os níveis de ensino, inclusive a educação da comunidade, objetivando capacitá-la para participação ativa na defesa do meio ambiente". Nessa linha, assevera Fábio Fernandes que a efetiva prevenção depende da formação e da disseminação de uma consciência ecológica, cujo pressuposto reside na educação ambiental.

O princípio da precaução tem fundamento na Declaração do Rio de Janeiro de 1992 sobre meio ambiente e desenvolvimento, de acordo com o contido no seu Princípio 15:

Para proteger o meio ambiente medidas de precaução devem ser largamente aplicadas pelos Estados segundo suas capacidades. Em caso de risco de danos graves e irreversíveis, a ausência de certeza científica absoluta não deve servir de pretexto para procrastinar a adoção de medidas visando a prevenir a degradação do meio ambiente. ${ }^{207}$

${ }^{206}$ FERNANDES, Fábio. Meio ambiente geral e meio ambiente do trabalho: uma visão sistêmica. São Paulo: LTr, 2009. p. 106.

${ }^{207}$ MELO, Raimundo Simão de. Direito ambiental do trabalho e a saúde do trabalhador: responsabilidades legais, dano material, dano moral, dano estético, indenização pela perda de uma chance, prescrição. São Paulo: LTr, 2008. 
Maria Isabel Cueva Moraes traça com propriedade a distinção entre os princípios, explicitando que a doutrina em direito ambiental aponta que o princípio da precaução difere do da atuação preventiva (ou da prevenção) porque, enquanto a prevenção demanda a eliminação dos perigos comprovados, a precaução exige uma atuação racional para com os bens ambientais que antecede a evidência científica absoluta quanto ao nexo causal dos possíveis impactos danosos ao meio ambiente, indo além da adoção de medidas para afastar o perigo da poluição iminente ou já existente. A precaução objetiva prevenir uma suspeita de perigo e, assim, prevê uma política ambiental adequada. ${ }^{208}$

Raimundo Simão de Melo destaca que o princípio da precaução se constitui no princípio norteador das políticas ambientais, à medida que este se reporta à função primordial de evitar os riscos e a ocorrência dos danos ambientais. Trata-se, assim, da garantia contra os riscos potenciais que, de acordo com o estado atual do conhecimento, ainda não podem ser identificados. Afirma esse autor que esse princípio incute a ideia da inversão do ônus da prova em favor do meio ambiente, porque a incerteza científica milita em favor do meio ambiente e da sociedade. ${ }^{209}$

Esse autor ensina que no direito positivo brasileiro o princípio da precaução tem seu fundamento na Lei 6.938/1981 - Lei de Política Nacional do Meio Ambiente, no artigo $4^{\circ}{ }^{\circ}$, incisos I e IV, tendo sido expressamente incorporado no artigo $225, \S 1 .^{\circ}$, inciso $\mathrm{V}$, da Constituição Federal e na Lei de Crimes Ambientais (Lei 9.605/1998, artigo 54, § 3. ${ }^{\circ}$ ).

Por sua vez, o princípio da prevenção está consagrado no caput do artigo 225 da Carta Maior, quando diz que incumbe ao Poder Público e à coletividade o dever de defender e preservar o meio ambiente equilibrado para presentes e futuras gerações.

E, na seara trabalhista, tal princípio é observado no artigo $7 .^{\circ}$, inciso XXII, da Constituição Federal, que estabelece como direito do trabalhador urbano e rural a redução

${ }^{208}$ MORAES, Maria Isabel Cueva. A negociação coletiva ambiental trabalhista e seus frutos. 2008. Dissertação (Mestrado) - Faculdade de Direito da USP, São Paulo, p. 34.

${ }^{209}$ MELO, Raimundo Simão de. Direito ambiental do trabalho e a saúde do trabalhador: responsabilidades legais, dano material, dano moral, dano estético, indenização pela perda de uma chance, prescrição. São Paulo: LTr, 2008. p. 45-46. 
dos riscos inerentes ao trabalho por meio de normas de saúde, higiene e segurança. ${ }^{210} \mathrm{E}$, para a consecução desse direito, incumbem ao Estado a educação ambiental e, primordialmente, a fiscalização dos ambientes de trabalho; e não se pode olvidar da obrigação dos empregadores no que tange à orientação dos trabalhadores sobre os riscos existentes no meio ambiente de trabalho, bem como quanto à adoção de medidas de proteção, tanto coletivas como individuais, por meio de equipamentos adequados nos termos do artigo 157 da CLT ou por outras formas voltadas à eliminação ou redução dos riscos inerentes ao trabalho. Salientem-se aqui, como exemplos de medida preventiva, a limitação da jornada praticada, a diminuição das horas extras, a concessão de pausas intrajornada e outras medidas que serão oportunamente examinadas.

\subsubsection{Princípio da participação}

Esse princípio reflete a premência pela efetiva atuação da coletividade na defesa do meio ambiente, pois a obrigação da preservação ambiental não pode ser relegada tão somente ao Poder Público; a concepção atual é pelo exercício de uma cidadania participativa e solidária. A ação estatal isolada é insuficiente para evitar a degradação ambiental e para garantir um meio ambiente equilibrado para as presentes e futuras gerações. Impõe-se estimular e proporcionar uma gestão participativa do Estado, com a inclusão dos diversos atores sociais: o chamado terceiro setor, ONGs; universidades; entidades representativas das categorias profissionais e patronais, entre outros.

Ensina Raimundo Simão de Melo que o princípio da participação decorre do disposto no caput do artigo 255 da Constituição Federal, de que incumbe ao Poder Público e à coletividade o dever de defender e preservar o meio ambiente, essencial à sadia qualidade de vida. Ressalta, assim, que tal obrigação não é somente do Estado, tampouco apenas da sociedade, mas de ambos. ${ }^{211}$

Nessa esteira, quanto ao meio ambiente do trabalho, há atribuição estatal, por meio do Ministério do Trabalho e Emprego, que elabora as normas de prevenção e

\footnotetext{
${ }^{210}$ MELO, Raimundo Simão de. Direito ambiental do trabalho e a saúde do trabalhador: responsabilidades legais, dano material, dano moral, dano estético, indenização pela perda de uma chance, prescrição. São Paulo: LTr, 2008. p. 44-45.

${ }^{211}$ Idem, ibidem, p. 50.
} 
melhoria dos ambientes laborais, bem como exerce a fiscalização, com poder de imposição de multas e até de interdição de estabelecimentos ou de embargos de obras. Tais previsões estão contidas ao longo do Capítulo V da CLT.

E a Saúde do Trabalhador, que recebeu nova definição, a partir do delineamento constitucional implementado pela Carta de 1988, com a instituição do Sistema Único de Saúde (SUS), passou a ser incorporada como área de competência própria da saúde. Dessa forma, ao SUS cabe o papel de executar ações nas áreas da vigilância sanitária e epidemiológica, bem como as de saúde do trabalhador. Cumpre dizer que tais conquistas resultaram de marcada participação dos movimentos social e sindical durante o processo constituinte.

Assim, além do papel estatal e das obrigações patronais, incumbe aos sindicatos, parte da sociedade organizada, a defesa dos interesses coletivos ou individuais da categoria (artigo 8..$^{\circ}$ III, CF), incluído o meio ambiente de trabalho. A prevenção de doenças e de acidentes de trabalho é exercida pelas Comissões Internas de Prevenção de Acidentes (Cipas), ou mesmo por trabalhadores membros de Comissões de Fábricas ou de demais comissões representativas da categoria profissional. Os respectivos papéis serão detalhados e aprofundados nos tópicos seguintes.

Aponta Maria Isabel Cueva Moraes, lastreando-se em Celso Antonio Pacheco Fiorillo e Marcelo Abelha Rodrigues, subprincípios vinculados ao da participação, como os da informação (artigo 220 da Constituição Federal, que engloba não somente o direito de informar, mas também o direito difuso de ser informado) e da educação ambiental (previsto no artigo $225, \S 1 .^{\circ}, \mathrm{VI}$, da Carta). ${ }^{212}$

Nessa linha, para a eficiência e a eficácia de qualquer medida preventiva, observa Raimundo Simão de Melo que é indispensável que os trabalhadores tenham direito de:

a) informação sobre os riscos ambientais, os métodos, as condições de trabalho, etc.; c) formação teórica e prática quando da contratação; c) apresentar propostas ao empregador para eliminação para eliminação dos riscos ambientais; d) abandonar o local de trabalho quando presente

${ }^{212}$ MORAES, Maria Isabel Cueva. A negociação coletiva ambiental trabalhista e seus frutos. 2008. Dissertação (Mestrado) - Faculdade de Direito da USP, São Paulo, p. 36. 
risco grave e iminente para sua saúde; e e) medidas preventivas, individuais e coletivas. ${ }^{213}$

Nesse sentido, o empregador, em vez de somente se aproveitar do potencial do empregado, deve também respeitá-lo, ouvindo suas sugestões acerca do processo de produção e demais questões atinentes à organização do trabalho, dado que os trabalhadores conhecem seu mister e sabem apontar os riscos e auxiliar nos procedimentos de prevenção, à luz do princípio da participação.

\subsubsection{Princípios da responsabilização e do poluidor-pagador}

A Lei de Política Nacional de Meio Ambiente (Lei 6.938/1981) define como poluição a degradação da qualidade ambiental resultante de atividades que direta ou indiretamente: prejudiquem a saúde, a segurança e o bem-estar da população ou afetem as condições estéticas ou sanitárias do meio ambiente (artigo 3. , III, "a" e "d"), e como poluidor "a pessoa física ou jurídica, de direito público ou privado, responsável, direta ou indiretamente, por atividade causadora de degradação ambiental” (artigo 3. ${ }^{\circ}$, IV).

Norma Sueli Padilha explicita que, de acordo com o tratamento constitucional dado à matéria, caracteriza-se como poluição do meio ambiente do trabalho a degradação do meio ambiente do trabalho, resultante de atividades que prejudiquem a saúde, a segurança e o bem-estar dos trabalhadores. ${ }^{214}$

Raimundo Simão de Melo destaca que o princípio do poluidor-pagador tem duas razões fundamentais: em primeiro lugar, prevenir o dano ambiental e, em segundo, não havendo a prevenção, a sua reparação da forma mais integral possível. De acordo com esse princípio, aos que desenvolvem atividades que possam causar danos ao meio ambiente impõe-se o dever de prevenir tal ocorrência, com a utilização de equipamentos e meios necessários para evitar o dano. Em caso de não cumprimento dessa obrigação, a responsabilidade do provocador do dano ao meio ambiente é objetiva, nos termos da

${ }^{213}$ MELO, Raimundo Simão de. Direito ambiental do trabalho e a saúde do trabalhador: responsabilidades legais, dano material, dano moral, dano estético, indenização pela perda de uma chance, prescrição. São Paulo: LTr, 2008. p. 59.

${ }^{214}$ PADILHA, Norma Sueli. Do meio ambiente do trabalho equilibrado. São Paulo: LTr, 2002. p. 66. 
previsão da Lei de Política Nacional do Meio Ambiente (artigo 14, § 1. ${ }^{\circ}$ ), disposição esta recepcionada pela Constituição Federal, conforme artigo $225, \S 3 .^{\text {o }}{ }^{215}$

Assim, a responsabilidade pela reparação dos danos é imposta ao poluidor, sendo necessário demonstrar somente a existência do dano e o nexo causal; há prescindibilidade de existência de culpa ou dolo para imposição do dever de indenizar.

Portanto, o princípio poluidor-pagador é aquele que impõe ao poluidor o dever de arcar com as despesas de prevenção, reparação e repressão da poluição. Ou seja, estabelece que o causador da poluição e da degradação dos recursos naturais deve ser o responsável principal pelas consequências de sua ação (ou omissão).

Destaca Raimundo Simão de Melo que a reparação dos danos deve abranger não somente o meio ambiente genericamente considerado, como também terceiros atingidos pela atividade poluidora, como dispõe o $§ 1 .^{\circ}$ do artigo 14 da Lei 6.938/1981..$^{216}$

Há que se ressaltar um terceiro aspecto do princípio do poluidor-pagador, o da responsabilidade solidária; reitere-se que, nos termos do caput do artigo 225 da Constituição Federal, o Poder Público e a coletividade têm o dever de defendê-lo e preservá-lo; assim, ambos são legitimados passivos, sendo solidariamente responsáveis pela reparação dos danos causados pela atividade poluidora, como também prevê a Lei de Política Nacional do Meio Ambiente.

Saliente-se que a aplicação do princípio do poluidor-pagador deve ser mais uma garantia para a sociedade, uma vez que o melhor é desestimular o dano ambiental para que ele não aconteça. Assim, o Direito Ambiental no Brasil utiliza o referido princípio para tornar eficaz outro princípio, já tratado anteriormente, o princípio da precaução.

${ }^{215}$ MELO, Raimundo Simão de. Direito ambiental do trabalho e a saúde do trabalhador: responsabilidades legais, dano material, dano moral, dano estético, indenização pela perda de uma chance, prescrição. São Paulo: LTr, 2008. p. 48.

${ }^{216}$ Idem, ibidem. 


\subsubsection{Arcabouço normativo estatal de proteção ao direito à saúde no trabalho}

No plano internacional, há muito a preocupação com os acidentes de trabalho tem sido objeto de estudos, destaca Segadas Vianna, ressaltando os princípios diretivos da organização dos serviços de proteção ao trabalhador estabelecidos pela Comissão Mista constituída pela OIT e pela Organização Mundial da Saúde (OMS), que visam a "criar um ambiente mais favorável, facilitar a adaptação entre os homens, suas funções, melhorar a saúde e o moral do pessoal e, por consequência, as relações humanas"; e, ainda, "reduzir o custo da reparação das moléstias profissionais, o absenteísmo, as taxas de acidentes, o custo da reparação dos acidentes em virtude da existência de socorros e cuidados imediatos, e, enfim, em razão desses fatores, à melhoria, no campo da produtividade". ${ }^{217}$

A preocupação dos organismos internacionais com os acidentes de trabalho justifica-se nos números alarmantes, equivalentes aos números de mortos nas guerras: o Relatório da Organização Internacional do Trabalho (OIT), divulgado durante o XIX Congresso sobre Segurança e Saúde no Trabalho em 2011, mostra que o número de feridos em acidentes de trabalho chega a 317 milhões por ano no mundo, e registra uma média de mais de 6.300 mortes diárias relacionadas com o trabalho, isto é, cerca de 2,3 milhões de mortes no ano. ${ }^{218}$

No Brasil, de acordo com a 19. ${ }^{\text {a }}$ edição do Anuário Estatístico da Previdência Social (AEPS), disponível no sítio do Ministério da Previdência Social, ${ }^{219}$ houve uma diminuição dos acidentes de trabalho em 2010 com relação a 2009; contudo, o número de trabalhadores que perderam a vida por acidente de trabalho aumentou no último ano. Segundo o Anuário, em 2010 foram registrados 701.496 acidentes contra 723.452 em 2009; no entanto, foram registradas 2.712 mortes em 2010, e, em 2009, 2.560.

Importa ressaltar que os dados estatísticos nacionais retratam dimensões trágicas. São vários os fatores que culminam nesta tragédia que se repete, ano a ano: precarização das relações de trabalho, com desemprego, subemprego, trabalho informal, conforme

\footnotetext{
217 SÜSSEKIND, Arnaldo et al. Instituições de direito do trabalho. São Paulo: LTr, 2000. v. 2, p. 913.

218 Disponível em: <www.ilo.org>. Acesso em: 16 jul. 2012.

${ }^{219}$ Disponível em: <http://www.previdencia.gov.br/conteudoDinamico.php?id=1209>. Acesso em: 16 jul. 2012.
} 
mencionado anteriormente; além disso, há carência educacional, e uma gritante distorção na distribuição de renda, o que faz com que os trabalhadores se submetam às piores condições de trabalho em troca de ganhos, além de falta de políticas públicas preventivas de doenças e acidentes do trabalho.

No que diz respeito ao meio ambiente de trabalho, as Convenções da OIT, ratificadas pelo Brasil, são as de n. 148, 152, 155 e 161. Dentre elas, cabe destacar a Convenção 155, aprovada em 3 de junho de 1981, com vigência nacional a partir de 18 de maio de 1993, dedicada à promoção da segurança e saúde dos trabalhadores, como bem a ser conquistado; aplica-se a todas as áreas de atividade econômica; prevê que o termo "trabalhadores" abrange todas as pessoas empregadas, incluindo os funcionários públicos (artigo 3. , alínea "b").

São objetivos da tutela jurídica labor ambiental da Convenção 155, entre outros:

a) higidez no local de trabalho;

b) segurança na construção e no manejo de máquinas e ferramentas;

c) proteção dos trabalhadores contra agentes químicos, biológicos e físicos;

d) gestão e adequação das atividades, das operações e dos processos relacionados ao trabalho, com a determinação dos seus graus de risco e a sua classificação como proibidos, limitados ou controlados;

e) implementação de um sistema apropriado de fiscalização do meio ambiente do trabalho;

f) realização de pesquisas de acidentes do trabalho e publicações periódicas das informações;

g) adoção compulsória de técnicas assecuratórias da segurança no trabalho e de processos de controle da ação de agentes químicos. 
Em 15 de junho de 2006, a 95. ${ }^{\text {a }}$ Conferência Internacional da OIT, ocorrida em Genebra, aprovou a Convenção 187, considerada como "a Convenção sobre o Marco Promocional para a segurança e saúde no trabalho", por estabelecer a obrigatoriedade de adoção pelos países-membros de uma política nacional sobre segurança e saúde no trabalho e meio ambiente do trabalho, além de um sistema nacional para aplicação dessa política e de programas voltados à sua implementação. Cuida da cultura da prevenção e da promoção da segurança e saúde no trabalho e envolve as pequenas e microempresas, bem como as empresas contratadas por meio da terceirização.

Essa Convenção ainda não foi ratificada pelo Brasil, em que pesem os apelos e os esforços dos organismos internacionais. Nesse sentido, a Declaração de Seul sobre Segurança e Saúde no Trabalho, elaborada na República da Coreia a 29 de junho de 2008, no âmbito do XVIII Congresso Mundial sobre Segurança e Saúde no Trabalho, organizado conjuntamente pela OIT, Associação Internacional da Segurança Social (AISS) e Agência Coreana para a Segurança e Saúde no Trabalho (Kosha), com a participação de especialistas, representantes de empregadores e trabalhadores, que estabeleceu, entre outras, as seguintes diretrizes, a serem observadas inclusive pelos governos dos Estadosmembros:

[...] 3. A melhoria contínua da segurança e saúde no trabalho deveria ser promovida através da introdução de sistemas de gestão da segurança e saúde no trabalho que incluam o desenvolvimento de uma política nacional que tenha em conta os princípios enunciados na Parte II da Convenção (n. 155), sobre Segurança e Saúde dos Trabalhadores, de 1981 da OIT.

4. Os governos deveriam:

- Considerar como prioritária a ratificação da Convenção (n. 187) sobre o Quadro Promocional para a Segurança e Saúde no Trabalho de 2006 da OIT, bem como de todas as restantes Convenções pertinentes da OIT em matéria de segurança e saúde no trabalho e deveriam assegurar a aplicação das suas disposições para melhorar, de forma sistemática, os desempenhos nacionais em segurança e saúde no trabalho 3. A melhoria contínua da segurança e saúde no trabalho deveria ser promovida através da introdução de sistemas de gestão da segurança e saúde no trabalho que incluam o desenvolvimento de uma política nacional que tenha em conta os princípios enunciados na Parte II da Convenção (n. 155), sobre Segurança e Saúde dos Trabalhadores, de 1981 da OIT [...].

Observe-se que a Cúpula sobre Segurança e Saúde mencionada, realizada no marco do XVIII Congresso de junho de 2008, ocorreu antes da eclosão da crise econômica 
e de emprego em nível mundial. Por isso, em 2001 foi realizado na Turquia O XIX Congresso sobre Segurança e Saúde no Trabalho, a maior reunião de especialistas de saúde e segurança em nível mundial, para discutir os avanços sobre o que foi estabelecido na Declaração de Seul. Nesse Congresso, o relatório elaborado registrou que, ao mesmo tempo em que se verifica uma tomada de consciência cada vez maior dos graves problemas que as condições inseguras e insalubres no local de trabalho causam à saúde e bem-estar de mulheres e homens, além de seus efeitos negativos sobre a produtividade, o emprego e a economia em geral, constatam-se os efeitos contrários, provocados pela crise econômica mundial. Assim, o relatório afirma que

[...] a recessão mundial deve ter tido um impacto significativo sobre a segurança e a saúde dos trabalhadores e sobre suas condições de trabalho. Embora seja cedo para falar sobre os efeitos em longo prazo nas taxas de acidentes e enfermidades em nível mundial, existem provas de alguns dos progressos alcançados recentemente em termos de promoção de SST estão se perdendo, ao mesmo tempo em que as empresas lutam para permanecer produtivas. ${ }^{220}$

Cumpre registrar que no Brasil o Governo Federal empreendeu ação considerada por muitos prevencionistas como importante conquista para a área de saúde do trabalhador: foi instituída pelo Poder Executivo federal a PNSST (Política Nacional de Segurança e Saúde no Trabalho), por meio do Decreto 7.602, de 7 de novembro de 2011; elaborada de forma tripartite, a política promete integrar as ações de segurança e saúde no trabalho dos três ministérios (Trabalho, Saúde e Previdência Social), e traz entre os seus princípios a universalidade; propõe que a segurança e a saúde alcancem a todos os trabalhadores, incluindo informais e o servidor público; tem como princípio o diálogo social, e, embora crie as condições necessárias para a implementação da Convenção 187 da OIT, a ratificação de tal diploma não foi efetivada, o que se espera que ocorra o quanto antes. ${ }^{221}$

De todo modo, em termos de legislação ambiental, inclusive na seara do meio ambiente do trabalho, salienta Raimundo Simão de Melo que o Brasil é um dos países mais

\footnotetext{
${ }^{220}$ Disponível em: $\quad<$ http://www.oit.brasil.org.br/content/xix-congresso-sobre-seguranca-e-saude-notrabalho> Acesso em: 23 jul. 2012

${ }^{221}$ Disponível em: <http://www.laboreweb.com.br/Governo-aprova-Politica-Nacional-de-SST_168> Acesso em: 16 jul. 2012.
} 
avançados do mundo. ${ }^{222}$ Há sólido instrumental normativo voltado à proteção da saúde dos cidadãos brasileiros. A Constituição Federal de 1988, no seu artigo 7. ${ }^{\circ}$, inciso XXII, estabelece como direito do trabalhador urbano e rural a redução dos riscos inerentes ao trabalho por meio de normas de saúde, higiene e segurança; ademais, no seu Título VIII, que trata da ordem social, norteia um conjunto integrado de ações destinadas a assegurar os direitos relativos à saúde, à previdência e à assistência social; nele, há seção específica que trata do direito à saúde, inclusive a dos trabalhadores: o artigo 200 prevê que ao Sistema Único de Saúde (SUS) compete, além de outras atribuições, executar as ações de vigilância sanitária e epidemiológica, bem como as de saúde do trabalhador. Tais previsões influenciaram várias Constituições estaduais que seguiram a mesma linha, dentre elas a do Estado de São Paulo, do Amazonas, do Pará, da Bahia e de Rondônia. A Carta Estadual de São Paulo assegura no seu artigo 229, $\S 2 .^{\circ}$, o direito de o trabalhador recusar o trabalho, no caso de risco grave ou iminente, até a eliminação total, "sem prejuízo de quaisquer direitos".

A Lei de Política Nacional do Meio Ambiente (Lei 6.938/1991) e sua imprescindibilidade na preservação ambiental, inclusive do trabalho, já foram destacadas.

Insere-se no arcabouço legal o importante Capítulo V da CLT, alterado em 1977 pela Lei 6.514; e a Portaria 3.214/1978 e suas várias Normas Regulamentadoras. Somamse as convenções coletivas de trabalho e sentenças normativas proferidas pela Justiça do Trabalho nos Dissídios Coletivos, fruto das reivindicações que passaram a constar das pautas dos sindicatos dos trabalhadores.

Ressalte-se aqui a importância da Lei Orgânica da Saúde - Lei 8.080, de 19 de setembro de 1990, que assegura que a saúde é um direito fundamental do ser humano, e inclui no campo de atuação do SUS a vigilância sanitária e epidemiológica e a saúde do trabalhador.

Saliente-se que, no Estado de São Paulo, a Constituição Estadual, o Código de Saúde (Lei Complementar 791/1995) e o Código Sanitário (Lei 10.083/1998) determinam

\footnotetext{
${ }^{222}$ MELO, Raimundo Simão de. Direito ambiental do trabalho e a saúde do trabalhador: responsabilidades legais, dano material, dano moral, dano estético, indenização pela perda de uma chance, prescrição. São Paulo: LTr, 2008. p. 30.
} 
a atuação sobre os fatores ou situações de risco encontrados nos ambientes e processos produtivos de trabalho.

Destaque-se ainda a Lei 9.505/1997, que disciplina as ações e os serviços de saúde dos trabalhadores no Sistema Único de Saúde estadual.

\subsubsection{Medidas preventivas e protetivas da saúde do trabalhador}

Quando tratamos de medidas de prevenção e de proteção à saúde do trabalhador, o primeiro pensamento que vem à mente é paradoxal, pois imediatamente lembramos de cansaço, físico e mental; de estresse; de excesso de trabalho e de baixos salários.

Como foi visto no tópico que tratou da conceituação de "trabalho", enfocando influências históricas e concepções filosóficas, o trabalho passou de uma atividade menor e foi ganhando importância, a ponto de ser considerado fato de dignificação humana e mesmo um dever social. Nesse sentido, a virtude é o trabalho, e é este que confere dignidade ao homem. No entanto, se "trabalho" na Antiguidade e para os gregos significava esforço penoso e doloroso, e para o hebraísmo aproximava-se da ideia de pecado, utilizado como meio para os homens servirem a Deus, com a evolução das concepções filosóficas busca-se a valorização do trabalhador com a minimização dos aspectos perversos do trabalho, relacionados à fadiga e ao ânimo. Sabe-se que o trabalho realizado com um corpo cansado e o espírito desmotivado resulta em trabalho penoso e improdutivo. ${ }^{223}$

Como ensina Felice Battaglia,

[...] O consumo do nosso corpo não cresce na proporção do trabalho. Se faço um trabalho igual a um, não se pode dizer que terei um de fadiga e, por duas ou três horas de trabalho sucessivo, dois ou três de ulterior fadiga. Demonstrou-se, sem margem de erro, que o trabalho realizado por um músculo quando já cansado, o afeta ou (o que é o mesmo) lhe custa em energia mais do que um trabalho maior realizado em condições normais. Isto, aliás, é comprovado pela experiência pessoal. Quem quer que haja feito ascensões em montanhas, sabe bem que a última parte da subida antes de tocar o cume custa um esforço bem maior do que aquele

${ }^{223}$ SOUTO MAIOR, Jorge Luiz. Curso de direito do trabalho: teoria geral do direito do trabalho. São Paulo: LTr, 2011. v. 1, Parte I, p. 30, 36 e 38. 
dispendido em passagens mais difíceis, quando se estava menos cansado. O nosso corpo é uma perfeita máquina, mas não é como uma máquina, como um locomotor, que para cada quilograma de trabalho consome uma mesma quantidade de energia. Quando o nosso corpo está cansado, uma quantidade mesmo pequena de trabalho produz efeitos desastrosos. $[\ldots] .{ }^{224}$

No início do século XX, predominava uma concepção que apontava características humanas e pessoais, como idade, sexo, personalidade, inteligência, culminando por responsabilizar as vítimas pelos acidentes do trabalho. Tal concepção foi considerada reducionista, e foi alvo de críticas, pois se limitava a acusar as vítimas, poupando os detentores do capital e dos meios de produção da gestão e redução dos riscos.

Comenta Nadia Demoliner Lacerda que, após os anos 50, houve consenso no meio científico de que o acidente é um evento nascido da interação entre o trabalhador e demais componentes do meio ambiente de trabalho; assim, o acidente deixa de ser considerado um fenômeno isolado e circunscrito, e passa a ser entendido como um sintoma de disfuncionamento do sistema de trabalho. ${ }^{225}$

O conceito clássico da saúde ocupacional teve ampliação proposta pela Organização Panamericana da Saúde (OPAS), em 1983; assim, passou-se a empregar o termo "saúde dos trabalhadores". Essa nova proposta objetivou ampliar o escopo da saúde ocupacional, que abrangia apenas a identificação e o controle dos riscos profissionais nos ambientes de trabalho, agregando a ele a compreensão das relações entre atividade de trabalho e saúde, ou seja, uma visão estrutural da ocupação como determinante social. Para tanto, a saúde dos trabalhadores deveria contar com a atuação de diferentes instituições, com suas atribuições definidas pela legislação. ${ }^{226}$

Como examinamos no capítulo anterior, a organização do trabalho exige uma análise sob enfoque multicausal, multifatorial; o processo de produção envolve um

${ }^{224}$ BATTAGLIA, Felice. Filosofia do trabalho. São Paulo: Saraiva, 1958. p. 206.

${ }^{225}$ LACERDA, Nadia Demoliner. Segurança e saúde do trabalhador: para onde vamos? O debate nacional sobre a concepção preventiva do novo seguro de acidente. São Paulo: LTr, 2011. p. 26.

${ }^{226}$ MINAYO GOMEZ, Carlos et al. (Org.). Saúde do trabalhador na sociedade brasileira contemporânea. Rio de Janeiro: Fiocruz, 2011. p. 144-145. 
conjunto de elementos que se interagem, sendo o trabalhador um desses componentes. Para a correta proposição das medidas protetivas e preventivas da saúde do trabalhador, faz-se necessário examinar com precedência diversos fatores, como: duração e distribuição da jornada; forma da remuneração; forma de produção; fatores ergonômicos; aspectos relacionados ao comportamento da chefia e dos colegas de trabalho; maior ou menor participação no processo laboral; além dos demais elementos do meio ambiente de trabalho, como condições desgastantes e exposição a riscos, químicos, físicos e biológicos.

A duração da jornada de trabalho é estabelecida pelo inciso XIII do artigo $7 .^{\circ}$ da Constituição Federal, que estipula o período não superior a oito horas diárias e quarenta e quatro semanais como duração "normal" do trabalho. Constata-se pelo estudo realizado pelo Departamento Intersindical de Estatística e Estudos Socioeconômicos (Dieese), de acordo com dados colhidos até 2003, que a jornada semanal normal no Brasil é superior às dos países selecionados, com exceção a do Japão, até 1992, e à da Coreia; no entanto, esses países vêm apresentando redução na década de 90, como se vê no quadro abaixo:

\section{Jornada de trabalho semanal em países selecionados - 1980-2003}

(horas)

\begin{tabular}{|c|c|c|c|c|c|c|c|c|c|c|c|}
\hline Países & 1980 & 1984 & 1988 & 1990 & 1992 & 1994 & 1998 & 2000 & 2001 & 2002 & 2003 \\
\hline Austrália(1) & - & - & 36,1 & 35,8 & 35,5 & 36,0 & 35,7 & 35,6 & 35,2 & 34,9 & 34,8 \\
\hline Alemanha(1) & 41,6 & 40,9 & 40,2 & 39,7 & 39,0 & 38,3 & 39,8 & 39,8 & 40,8 & 41,5 & 40,8 \\
\hline Canadá(1) & - & 32,0 & 32,1 & 31,3 & 30,8 & 31,2 & 31,4 & 31,6 & 31,6 & 31,9 & - \\
\hline Coreia $(2)$ & 51,6 & 52,4 & 51,1 & 48,2 & 47,5 & 47,4 & 45,9 & 47,5 & 47,0 & 46,2 & - \\
\hline Espanha(2) & 39,7 & 37,6 & 37,2 & 37,4 & 36,8 & 36,8 & 36,7 & 35,9 & 35,9 & 35,7 & 35,4 \\
\hline $\operatorname{EUA}(2)$ & 43,3 & 43,3 & 41,3 & 41,2 & 40,5 & 41,0 & 40,6 & 41,0 & 40,6 & 40,5 & 42,6 \\
\hline França(2) & 41,1 & 39,1 & 39,1 & 39,1 & 39,1 & 39,9 & 39,8 & 39,0 & 38,4 & 38,3 & 38,6 \\
\hline Israel(2) & 36,5 & 36,0 & 35,6 & 35,9 & 36,7 & 37,4 & 37,1 & 37,8 & 36,9 & 37,3 & 37,0 \\
\hline Japão(2) & - & - & 46,8 & 45,7 & 44,1 & 43,2 & 42,3 & 42,7 & 42,2 & 42,2 & 42,0 \\
\hline Noruega(2) & 35,5 & 35,0 & 35,8 & 35,3 & 34,9 & 35,0 & 35,3 & 35,1 & 34,9 & 34,8 & 34,6 \\
\hline $\begin{array}{c}\mathrm{R} . \\
\text { Unido(2)(3) }\end{array}$ & - & - & 40,6 & 40,5 & 40,0 & 40,1 & 40,2 & 39,8 & 39,8 & 39,6 & 39,6 \\
\hline Suíça(2) & - & - & - & - & 36,1 & 36,1 & 36,2 & 36,4 & 36,2 & 35,6 & 35,6 \\
\hline Itália(2) & - & - & - & - & - & 39,5 & 39,4 & 39,3 & 39,3 & 38,2 & 38,3 \\
\hline
\end{tabular}

FONTE: OIT, Anuário de Estadistica del Trabajo. In: laborsta.ilo.org

(1) Horas remuneradas. (2) Horas trabalhadas. (3) Exceto Irlanda do Norte. ${ }^{227}$

${ }^{227}$ DIEESE. Relatório técnico - Jornada de Trabalho em Países Selecionados. Ministério do Trabalho e Emprego, 2007, p. 35. Disponível em: <http://portal.mte.gov.br/data/files/FF8080812 BA5F4B7012BAAEF2B746775/Prod14_2007.pdf>. Acesso em: 14 ago. 2012. 
A prestação de trabalho, além do limite fixado pelas normas constitucionais, por lei ou por convenções e acordos coletivos de trabalho, tem sido fato corriqueiro não somente no Brasil, mas também em outros países, inclusive do chamado Primeiro Mundo. No nosso país, em particular, o desrespeito aos limites de jornada é prática comum, tanto que se criou no Judiciário trabalhista a tese da sobrejornada habitual para efeito de pagamento de reflexos de horas extras em outras verbas.

Em texto publicado em junho de 1982, Alain Wisner já se referia às reivindicações de 30 anos atrás, de redução da jornada de 48 horas para 40 horas, na indústria automobilística, acrescentando que a redução da jornada está na linha de frente da realidade política e social, não mais para passar para 40 horas, mas sim de 40 para 35 horas. $^{228}$

É certo que as oscilações políticas e econômicas mundiais, em especial as verificadas na crise econômica de 2008, com recrudescimento desde 2011, afetam o nível de emprego em praticamente todos os países, nesse mundo globalizado. Em decorrência, o número de horas trabalhadas tende a aumentar, dado que as empresas ficam temerosas com os destinos da economia e passam a reduzir a contratação de mão de obra. As alterações ocorridas no mundo do trabalho e sua influência na extensão e na intensidade da jornada são apontadas pelo Dieese no estudo mencionado:

[...] a partir da década de 80, nos países desenvolvidos, e na década de 90, nos países em desenvolvimento, a reestruturação produtiva, as novas tecnologias e as novas, ou renovadas, formas de flexibilização da utilização do tempo de trabalho trouxeram novos elementos que interferem na extensão e na intensidade da jornada de trabalho. $O$ trabalho aos domingos e feriados, o "banco de horas", a terceirização, o trabalho temporário, o tempo parcial, o trabalho em turnos de revezamento, o trabalho noturno, a prestação de serviço como autônomo, o estágio e o trabalho a domicílio são todas novas ou renovadas formas de distribuição do tempo de trabalho que tornaram a discussão em torno da jornada de trabalho cada vez mais complexa. [...]. ${ }^{229}$

${ }^{228}$ WISNER, Alain. A inteligência no trabalho: textos selecionados de ergonomia. São Paulo: Fundacentro, 1994. p. 45.

${ }^{229}$ DIEESE. Relatório técnico - Jornada de Trabalho em Países Selecionados. Ministério do Trabalho e Emprego, 2007, p. 18. Disponível em: <http://portal.mte.gov.br/data/files/FF8080812BA5 F4B7012BAAEF2B746775/Prod14_2007.pdf>. Acesso em: 14 ago. 2012. 
Estudos científicos apontam de forma consensual que as jornadas de trabalho que mais distúrbios acarretam no organismo humano são as jornadas noturnas e as organizadas em turnos de revezamento. Isso porque a jornada noturna não respeita o chamado ciclo circadiano, de ativação psicossomática e vigília durante o dia e de desativação e de sono durante a noite, em ciclos de doze horas cada. ${ }^{230} \mathrm{E}$, por essa razão, a hora noturna é computada de forma reduzida e o trabalhador recebe o adicional noturno; e a jornada em turnos ininterruptos de revezamento é limitada a 6 horas, salvo negociação coletiva (artigo 7. ${ }^{\circ}$, inciso XIV, CF).

Alain Wisner chama a atenção que o trabalho, como todas as atividades, engloba três aspectos: físico, cognitivo e psíquico, e cada um deles pode determinar uma sobrecarga, como já tratamos ao examinarmos o processo de organização do trabalho. ${ }^{231}$ Nesse sentido, explicita esse autor que o homem tem um corpo do qual os fenômenos psicológicos não podem ser dissociados. Dessa forma, são diversos os fatores que podem causar impactos negativos sobre o homem, física ou psicologicamente; por isso, ensina Wisner, devemos também nos interessar pelas relações entre o comportamento e as variações do estado psicológico (ciclo circadiano, fadiga, fome...). ${ }^{232}$

Nesse sentido, e quando se examina a densidade do trabalho, seja pela não observância do ciclo circadiano, seja pela fadiga, Alain Wisner afirma categoricamente que a redução dos horários é o único meio de diminuir os riscos que o trabalho por turnos provoca à saúde do trabalhador. Ressalta determinadas atividades profissionais, que realizam esforço mental tão denso que não é possível mantê-lo durante todo o tempo, mesmo em uma jornada de trabalho de 8 horas ou até de 7 horas. Aponta como solução aquela adotada para as telefonistas e professores: a redução oficial do tempo de trabalho, sem redução do salário. ${ }^{233}$

\footnotetext{
${ }^{230}$ LACERDA, Nadia Demoliner. Segurança e saúde do trabalhador: para onde vamos? O debate nacional sobre a concepção preventiva do novo seguro de acidente. São Paulo: LTr, 2011. p. 29.

${ }^{231}$ WISNER, Alain. A inteligência no trabalho: textos selecionados de ergonomia. São Paulo: Fundacentro, 1994. p. 13.

${ }^{232}$ Idem, ibidem, p. 39.

${ }^{233}$ Idem, p. 45.
} 
E, quando se trata de trabalho realizado em condições de insalubridade, a redução da jornada, conjugada com melhorias contínuas no ambiente de trabalho, com atenção prioritária para a eliminação do agente agressivo, são medidas apontadas por Sebastião Geraldo de Oliveira, como tendência moderna à proteção da saúde do trabalhador. ${ }^{234}$

Diga-se, aliás, que a duração mais curta da jornada, para trabalhos realizados em condições adversas, era recomendação feita pelo Papa Leão XIII, na Encíclica Rerum Novarum, de 15 de maio de $1891 .^{235}$

Quanto à forma de remuneração, pode-se afirmar que o ganho por produção, por tarefa ou peça, é fator nocivo saúde do trabalhador, que tem seu ritmo de trabalho impulsionado, acelerado, na expectativa de obtenção de maior rendimento. É sabido que a remuneração no corte manual de cana-de-açúcar, assim como em outras atividades agrícolas, como a colheita de laranja, café etc., é calculada com base na produção auferida pelo trabalhador. Ora, tal ajuste remuneratório é um "incentivo" a que o trabalhador ultrapasse os limites de suas forças físicas e mentais, a fim de receber um salário maior, algo mais do que o mero salário de subsistência. Por essa razão, são frequentes os relatos de trabalhadores que, em razão das condições de trabalho, adquiriram doença ocupacional, especialmente lombalgias de esforço; Lesões por Esforços Repetitivos/Distúrbio Osteomuscular Relacionado ao Trabalho (LER/DORT), relatados nos processos em trâmite nas Varas do Trabalho do interior do Estado de São Paulo; tem havido, inclusive, mortes por exaustão desses trabalhadores, como examinaremos mais a frente.

No que tange à forma de produção ou de realização da tarefa, o trabalho repetitivo, monótono e alienante cria a insatisfação, porta de entrada, segundo Christophe Dejours, para as descompensações mentais e doenças somáticas. ${ }^{236}$ Esse autor ilustra com situações de trabalho repetitivo, como o que é realizado na linha de produção, no trabalho por peças ou em certos trabalhos de escritório de informática ou nos bancos. Denomina

\footnotetext{
${ }^{234}$ OLIVEIRA, Sebastião Geraldo de. Proteção jurídica à saúde do trabalhador. 5. ed. São Paulo: LTr, 2010. p. 131.

${ }^{235}$ Disponível em: <http://www.vatican.va/holy_father/leo_xiii/encyclicals/documents/hf_l-xiii_enc_1505 1891_rerum-novarum_po.html>. Acesso em: 14 ago. 2012.

${ }^{236}$ DEJOURS, Christophe. A loucura do trabalho: estudo de psicopatologia do trabalho. São Paulo: Cortez Oboré, 1988. p. 133.
} 
esse trabalho organizado de forma rígida de trabalho "taylorizado". Pondera que nem todos os trabalhadores enfrentam a monotonia da tarefa com idênticas possibilidades defensivas, e aqueles com defesas comportamentais menos eficazes têm seu sofrimento notoriamente agravado. $^{237}$

As tarefas repetitivas ou monótonas acabam por não exigir mais raciocínio, praticamente dispensando a interferência mental; acarretam, com o passar do tempo, uma redução da capacidade física e mental, propiciada pela falta de novos desafios, podendo chegar à "saturação psíquica", como cita Sebastião Geraldo de Oliveira. Esse autor menciona previsões normativas de diversos países no sentido de serem evitadas as tarefas monótonas e repetitivas, como a legislação da Noruega em vigor desde 1977; em Portugal, o Código do Trabalho prevê que o empregador tem obrigação de organizar o trabalho, com o intuito de nomeadamente a atenuar o trabalho monótono ou cadenciado em função do tipo de atividade. ${ }^{238}$

Dois aspectos importantes devem ser observados para o processo de melhoria das condições de trabalho: a efetiva participação dos trabalhadores na resolução de seus problemas de saúde e segurança e o enfoque na organização do trabalho, como aspecto a ser analisado na avaliação das condições laborais.

As obrigações básicas do empregador, para a garantia do direito à saúde dos seus empregados, de acordo com José Antônio Ribeiro de Oliveira Silva, estão disciplinadas em comandos constitucionais e legais e regulamentações; esse autor estabelece didaticamente divisões em dois aspectos: o direito à abstenção e à prestação, incluindo neste o direito à prevenção:

[...] No tocante ao primeiro aspecto, tem o trabalhador o direito de abstenção do empregador quanto ao fator tempo de trabalho: a) não exigência de prestação de horas extras habituais (art. 7. ${ }^{\circ}$, XIII e XIV, da $\mathrm{CF})$; b) não exigência de labor nos intervalos intra e interjornadas; c) não exigência de trabalho nos dias de repouso semanal e feriados, tampouco nos períodos de férias (art. 7. ${ }^{\circ}, \mathrm{XV}$ e XVII); d) não exigência de trabalho

${ }^{237}$ DEJOURS, Christophe. A loucura do trabalho: estudo de psicopatologia do trabalho. São Paulo: CortezOboré, 1988. p. 37-45.

${ }^{238}$ OLIVEIRA, Sebastião Geraldo de. Proteção jurídica à saúde do trabalhador. 5. ed. São Paulo: LTr, 2010. p. 103. 
da mulher durante o período de licença-maternidade (art. 7. $\left.{ }^{\circ}, \mathrm{XVIII}\right)$; e) não exigência de trabalho noturno, perigoso ou insalubre a menores de 18 anos (art. 7. ${ }^{\circ}$, XXXIII).

E também direito à abstenção quanto ao fator saúde mental ou psíquica, sendo que o direito de não agressão a essa saúde compreende: a) o não tratamento rigoroso, vexatório, quando das ordens e fiscalização do serviço; b) e a não exigência de produtividade superior às forças físicas e mentais do trabalhador.

Quanto às prestações a que está obrigado o empregador, trata-se de um imenso caudal de normas, envolvendo: a) a obrigação de prevenção; b) e a obrigação de reparação. Esta envolve a responsabilidade do empregador pelos danos de natureza física ou funcional (inclusive mental) causados ao empregado, em decorrência de acidente do trabalho ou doença ocupacional. ${ }^{239}$

Pode-se incluir dentre as obrigações patronais de prestação a de fornecer informações, na esteira da Convenção 148 da OIT, que prevê que "os trabalhadores ou seus representantes terão direito a apresentar propostas, receber informações e orientação e a recorrer a instâncias apropriadas, a fim de assegurar a proteção contra riscos profissionais [...]"; também a Convenção 155, além de assegurar o direito à informação, estabelece que "os trabalhadores e seus representantes na empresa devem receber treinamento apropriado no âmbito da segurança e da higiene do trabalho"; a Convenção 161 dispõe da mesma forma, "que os trabalhadores devem ser informados dos riscos para a saúde inerentes a seu trabalho".

Assim, são primordiais os cursos de treinamento e capacitação, tanto do trabalhador individualmente quanto da equipe, principalmente se o trabalho é desenvolvido em conjunto. Os trabalhadores devem ser orientados para a correta realização de sua tarefa, seja no tocante à postura ergonomicamente adequada para tal desempenho, utilização de adequados equipamentos de proteção individual (EPIs) ou manuseio correto de máquinas e equipamentos. Tais cursos podem ser ministrados também com a participação dos membros da Cipa, comissões de representantes dos empregados ou membros de sindicatos da categoria profissional.

\footnotetext{
${ }^{239}$ SILVA, José Antônio Ribeiro de Oliveira. A saúde do trabalhador na Constituição Federal e na legislação infraconstitucional - avaliação crítica. Disponível em: <http://camat.com.br/arquivos/artigos/artigo_ saude_do_trabalhador_na_cf_analise_critica_anamatra.pdf $>$. Acesso em: 3 ago. 2012.
} 
Mais essencial que os cursos de treinamento e capacitação é a educação do trabalhador. Não há como haver desenvolvimento sem educação de qualidade, ainda mais em um mundo globalizado e extremamente competitivo. No Brasil a desigualdade social se perpetua, pois o topo da pirâmide social tem elevado grau de instrução, enquanto a base dessa pirâmide também sofre com a carência educacional. A falta e a má formação, quase equivalentes, estão entre os fatores que propiciam riscos no ambiente de trabalho, na medida em que o trabalhador, que tem dificuldade para ler e compreender instruções, terá dificuldade para entender manuais e funcionamento de máquinas, utilização de produtos químicos etc., e será provável vítima de acidente do trabalho. Nessa seara, ainda que as empresas possam contribuir, como são exemplos a formação ministrada pelas entidades do sistema Sesi/Senai/Senac, a responsabilidade pela educação do cidadão brasileiro não é do empregador, e sim governamental. Nesse passo, é sempre preciso relembrar que a educação é direito social assegurado no artigo $6^{\circ}$ da Constituição Federal, que necessita ser concretizado de forma ampla e eficaz, pois é medida essencial que propicia não somente a segurança, bem como o desenvolvimento, pessoal e do País.

Raimundo Simão de Melo elenca como instrumentos de prevenção e tutela do meio ambiente do trabalho: a) Programa Internacional para Melhoramento das Condições e do Meio Ambiente de Trabalho (PIACT); b) Estudo Prévio de Impacto Ambiental (EPIA); c) Negociação Coletiva; d) Comissões Internas de Prevenção de Acidentes (Cipas); e) Embargo e Interdição; f) Greve Ambiental; g) Programa de Prevenção de Riscos Ambientais (PPRA); h) Programa de Controle Médico de Saúde Ocupacional (PCMSO); i) Serviços Especializados em Engenharia de Segurança e em Medicina do Trabalho (SESMT); j) Equipamentos de Proteção Individual (EPIs); k) Perfil Profissiográfico Previdenciário (PPP); 1) Inquérito Civil; m) Termo de Ajustamento de Conduta (TAC); n) Audiência Pública; o) Recomendações; p) Ação Civil Pública Ambiental; q) Ação Popular; r) Mandado de Segurança Coletivo; s) Mandado de Injunção; t) Dissídio Coletivo. ${ }^{240}$

Alguns instrumentos são da incumbência e competência do Poder Público; outros são exercitados pelas entidades sindicais e pelos empregadores; outros ainda podem ser manejados por associações ou pelo cidadão interessado. O que importa é que tais

\footnotetext{
${ }^{240}$ MELO, Raimundo Simão de. Direito ambiental do trabalho e a saúde do trabalhador: responsabilidades legais, dano material, dano moral, dano estético, indenização pela perda de uma chance, prescrição. São Paulo: LTr, 2008. p. 83.
} 
instrumentos sejam utilizados, primordialmente, na prevenção da saúde e da integridade física e mental dos trabalhadores e que a atuação dos diversos atores sociais não seja estanque, e sim articulada, como se verá.

Saliente-se, por fim, que a ideia do trabalho como fator de dignificação da pessoa humana é exacerbada na nossa sociedade de consumo, e a pessoa sem trabalho sequer consegue se socializar; assim, a falta de trabalho, além de afetar a subsistência, é fator de adoecimento. No entanto, é preciso trabalhar menos, até o nível necessário para a preservação da vida privada e da saúde, como indica Jorge Luiz Souto Maior. ${ }^{241}$

Ou de acordo com a afirmativa utilizada por Edith Seligmann Silva:

Trabalhar não é somente "ganhar a vida", é também, e antes de tudo, preencher um papel. Deste ponto de vista, não ter trabalho é um drama, porém, ter um trabalho dentro do qual a possibilidade de investimento pessoal é estreita, não deixa de ter decorrências graves. ${ }^{242}$

\subsection{O papel dos poderes públicos. Da fiscalização do meio ambiente do trabalho}

Cumpre reconhecer que há vasto instrumental jurídico em vigor no Brasil e nosso país é fértil na produção legislativa, inclusive na seara da saúde do trabalhador. No entanto, a concretização dos direitos e garantias previstos em lei, em especial daqueles voltados à prevenção, não tem sido objeto de atenção privilegiada por parte dos nossos dirigentes. Verifica-se que não há atuação planejada e integrada entre os diversos órgãos públicos, ao revés, competências se superpõem, resultando em ausência de entrosamento entre os diversos órgãos públicos. Em que pese existir todo esse instrumental normativo e ainda que se reconheça que há destinação de verba pública, não se atinge uma atuação verdadeiramente eficaz na prevenção de acidentes e doenças do trabalho.

As ações de fiscalização nos ambientes de trabalho, para serem eficazes, pressupõem a existência de um ambiente democrático. Até 1988, as ações públicas em

\footnotetext{
${ }^{241}$ SOUTO MAIOR, Jorge Luiz. Curso de direito do trabalho: teoria geral do direito do trabalho. São Paulo: LTr, 2011. v. 1, Parte I, p. 41.

${ }^{242}$ SILVA, Edith Seligmann. Trabalho e desgaste mental: o direito de ser dono de si mesmo. São Paulo: Cortez, 2011. p. 84.
} 
saúde do trabalhador no Brasil eram centralizadas e se reduziam às inspeções do trabalho tradicionais efetuadas pelos Agentes de Inspeção do Ministério do Trabalho, e o Ministério da Saúde estava alijado do controle do processo de produção, como ressaltam Rodolfo Vilela, Gil Ricardi e Aparecida Iguti:

As ações de fiscalização nos ambientes de trabalho seguiam, habitualmente, um modelo de atuação tecnicista e afastado da vivência e dos saberes dos trabalhadores. [...] Além do mais, durante mais de meio século, o Ministério da Saúde esteve ausente do controle do processo de produção. Na Reforma Sanitária, as Conferências Nacionais de Saúde recuperaram esse papel para a saúde e os Programas de Saúde do Trabalhador passaram a atuar nesse novo cenário. A Constituição Federal de 1988 e a Lei Orgânica da Saúde (LOS), de 1990, devolvem ao Ministério da Saúde, o poder de intervenção nos ambientes de trabalho.

A nova Constituição e a LOS trouxeram também a possibilidade de resgate da questão ambiental para o campo da saúde coletiva, que constam nas atribuições do Sistema Único de Saúde, as de execução de ações de Vigilância Sanitária, incluindo a prevenção dos riscos à saúde decorrentes de fatores ambientais, do saneamento e dos ambientes e processos de trabalho. ${ }^{243}$

Pode-se afirmar que nos últimos anos houve evolução da estrutura pública voltada à atenção à saúde do trabalhador, inclusive com destinação de recursos. Ilustre-se com as alterações havidas na estrutura do SUS, do Ministério da Saúde: até o ano de 2002, existiam os antigos Centros de Referência em Saúde do Trabalhador (Cerest); no entanto, até então não tinham sido criados o Centro de Referência Estadual e os Regionais; somente no Estado de São Paulo, atualmente, há um de abrangência estadual e mais de 40 regionais. Como consta do portal do Ministério da Saúde, os Cerests promovem ações para melhorar as condições de trabalho e a qualidade de vida do trabalhador por meio da prevenção $e$ vigilância. $^{244}$

Por seu turno, a Rede Nacional de Atenção Integral à Saúde do Trabalhador (Renast), criada a partir de 2002, de acordo com o sítio do Ministério, é composta por 178

\footnotetext{
${ }^{243}$ VILELA, Rodolfo Andrade G.; GIL VICENTE FONSECA, Ricardi; IGUTI, Aparecida Mari. Experiência do Programa de Saúde do Trabalhador de Piracicaba: desafios da vigilância em acidentes do trabalho. Inf. Epidemiol, Sus, Brasília, v. 10, n. 2, jun. 2001. Disponível em: $<$ http://scielo.iec.pa.gov.br/scielo.php?script=sci_arttext\&pid=S010416732001000200003\&lng=es\&nr =iso $>$. Acesso em: 3 ago. 2012.

${ }^{244}$ Disponível em: <www.portal.saude.gov.br>. Acesso em: 30 jul. 2012.
} 
Centros Estaduais e Regionais de Referência em Saúde do Trabalhador (Cerest) e por uma rede sentinela de 1.000 serviços médicos e ambulatoriais de média e alta complexidade, responsáveis por diagnosticar os acidentes e doenças relacionados ao trabalho e por registrá-los no Sistema de Informação de Agravos de Notificação (Sinan-NET). A Renast responde pela execução de ações curativas, preventivas, de promoção e de reabilitação à saúde do trabalhador brasileiro, como uma das diretrizes da Política Nacional de Saúde do Trabalhador do Ministério da Saúde.

Saliente-se que há o debate sobre as funções e competências de cada esfera de governo no âmbito do SUS; assim, por exemplo, a Vigilância Sanitária é entendida como um conjunto de ações capazes de eliminar, diminuir ou prevenir riscos à saúde e de intervir nos problemas sanitários decorrentes do meio ambiente, produção e circulação de bens e prestação de serviços de interesse da saúde; conta também com estrutura estadual e municipal, com atribuições e competências definidas na Lei Orgânica da Saúde e nos Códigos de Saúde e Sanitário do Estado.

A inspeção do trabalho na indústria e no comércio é disciplinada no âmbito internacional pela Convenção 81 da OIT, que prevê que cada Estado-membro deve realizála por meio de servidores públicos estáveis, independentes de qualquer mudança de governo ou influência externa indevida. O Brasil ratificou essa Convenção em 1957 e a vigência nacional ocorreu a partir de $25.04 .1958 .^{245}$

Por sua vez, a fiscalização das normas de proteção ao trabalho é da competência do Ministério do Trabalho e Emprego (tem), cujas atribuições são verificar o cumprimento, por parte das empresas, da legislação de proteção ao trabalhador, com o objetivo de combater a informalidade no mercado de trabalho, e garantir a observância da legislação trabalhista. E, ainda, o Programa Segurança e Saúde no Trabalho do MTE tem como objetivo proteger a vida, promover a segurança e saúde do trabalhador. ${ }^{246}$

A legislação em vigor, artigos 626 a 642 da CLT, prevê que essa fiscalização incumbe às autoridades do Ministério do Trabalho e Previdência Social. Assim, cabe ao

\footnotetext{
245 SÜSSEKIND, Arnaldo. Convenções da OIT. São Paulo: LTr, 1998. p. 135-v e seguintes.

${ }^{246}$ Disponível em: <http://www.portal.mte.gov.br/fisca_trab/>. Acesso em: 30 jul. 2012.
} 
Poder Executivo orientar e fiscalizar as condições de trabalho e reprimir as empresas descumpridoras das normas, por meio da aplicação de multas, embargo de obras e até mesmo a interdição de estabelecimentos, maquinários e equipamentos que ofereçam risco grave e iminente à saúde e integridade física dos trabalhadores, conforme dispõem os artigos 154 e seguintes da CLT.

A normatização vigente, no entanto, não é suficiente para a garantia de um meio ambiente de trabalho seguro. Os empregadores, no mais das vezes, preferem pagar as multas administrativas que lhe são aplicadas, pois são ínfimas (artigo 201 da CLT), do que investir em medidas de proteção, como observa Raimundo Simão de Melo. ${ }^{247}$

Há tendência de alcançar a simplificação e unificação das normas de segurança e medicina do trabalho, explicita Otavio Pinto e Silva. Esse autor ressalta que o objetivo almejado é um sistema que privilegie a prevenção, e pondera que há que se buscar o equilíbrio, pois excesso de leis gera descumprimento e a insuficiência leva ao abuso. A revalorização da inspeção do trabalho é tema, e esse autor destaca, quando diz que a fiscalização deve ser efetuada não só para preservar os dispositivos legais de tutela do trabalhador, como os relativos à medicina e segurança do trabalho, mas também para assegurar o cumprimento das normas contidas nos convênios coletivos de trabalho, como forma de prestigiar a negociação coletiva de trabalho. ${ }^{248}$ Assim, chama a atenção para a importância da participação de outros atores sociais, como os sindicatos, que devem agir em colaboração com o Poder Público, para a eficiência da fiscalização, como abordaremos a seguir.

É preciso registrar que no nosso país há falta de formação voltada à prevenção, não somente no setor da produção, bem como nos demais ramos da atividade econômica. São públicos, notórios e alarmantes os índices de acidentes, por exemplo, no ramo da construção civil. ${ }^{249}$ Assim, é comum constatar que as empresas não somente economizam

${ }^{247}$ MELO, Raimundo Simão de. Direito ambiental do trabalho e a saúde do trabalhador: responsabilidades legais, dano material, dano moral, dano estético, indenização pela perda de uma chance, prescrição. São Paulo: LTr, 2008. p. 78.

${ }^{248}$ SILVA, Otavio Pinto e. Subordinação, autonomia e parassubordinação nas relações de trabalho. São Paulo: LTr, 2004. p. 187.

249 "A retomada das obras de infraestrutura e construção imobiliária elevou o número de acidentes de trabalho que resultam em mutilações ou mortes no Brasil. Entre janeiro e outubro de 2011, pelo menos 
em equipamentos, como também em treinamento e capacitação de seus empregados. E, quando os auditores fiscais verificam a irregularidade e aplicam a multa prevista em lei, há a possibilidade de interposição de recursos administrativos, que na realidade postergam a solução dos problemas.

Por isso, é vital a importância da fiscalização quanto às normas de saúde e segurança no trabalho, pois há que ser priorizada a prevenção a todo custo, como único meio eficaz de evitar danos à integridade física e mental dos trabalhadores e seus nocivos impactos sociais.

Todavia, não há estrutura humana e material adequadas; não há no território nacional número de auditores fiscais suficiente para que haja uma exitosa inspeção do trabalho; os recursos humanos e técnicos são insuficientes na área urbana, e mais ainda no meio rural, consideradas as dimensões continentais do nosso país. Cumpre ressaltar que no trabalho rural, em particular, são encontradas as piores formas de exploração do trabalho humano, com exposição a agrotóxicos nas lavouras, trabalho análogo ao de escravo e em condições degradantes.

Somem-se à insuficiência de auditores diversos fatores, como interesses corporativos, falta de descentralização administrativa e, em especial, a não priorização de políticas governamentais no sentido da atuação conjunta, integrada e planificada, e o resultado é que as necessárias medidas de proteção à saúde dos trabalhadores não são efetivadas. Como exemplo de entraves burocráticos mencione-se que a base de dados existente no Ministério da Previdência Social (MPS) deveria ser compartilhada com o Ministério da Saúde, bem como com o do Trabalho e Emprego, para propiciar o planejamento de ações, principalmente voltadas à prevenção de doenças e acidentes do trabalho; isso não ocorre por interesses corporativos arraigados ou por metas e objetivos dissonantes entre as Pastas. Ressalte-se que uma das principais dificuldades para a implantação de políticas eficazes e democráticas em Saúde do Trabalhador no Brasil têm sido a fragmentação e a dicotomia de atuação dos vários ministérios que atuam nesse

40.779 trabalhadores foram vítimas de acidentes graves de trabalho, dos quais 1.143 morreram, segundo o Ministério da Saúde. O número é $10 \%$ maior que em igual período do ano passado (37.035)." Disponível em: <http://economia.estadao.com.br/noticias/economia\%20brasil,cresce-acidente-detrabalho-com-volta-das-obras-,100136,0.htm>. Acesso em: 6 ago. 2012. 
campo, particularmente o Ministério da Saúde (MS), o Ministério do Trabalho e Emprego (MTE), o Ministério da Previdência e Assistência Social (MPAS).

Além das competências das mencionadas Pastas integrantes do Poder Executivo Federal, cumpre destacar a importância do Poder Legislativo na elaboração do arcabouço legal protetivo da saúde do trabalhador. Nesse sentido, ilustre-se com a previsão da Constituição do Estado de São Paulo, que assegura no seu artigo 229, § 2. ${ }^{\circ}$, o direito de o trabalhador recusar o trabalho, no caso de risco grave ou iminente, até a eliminação total, sem prejuízo de quaisquer direitos.

De importância ímpar o papel do Poder Judiciário, em especial a Justiça do Trabalho a partir da Emenda Constitucional 45/2004, por força do reconhecimento da competência dessa Especializada para o julgamento das demandas atinentes à saúde e à segurança dos trabalhadores, inclusive as relativas à responsabilidade civil do empregador quanto aos danos morais, materiais e estéticos decorrentes de doenças, acidentes do trabalho, bem como de assédio moral, à luz do artigo 114, VI, da Constituição Federal. ${ }^{250}$

Reconheça-se a evolução da jurisprudência dos nossos Tribunais, na tutela do meio ambiente do trabalho. O Supremo Tribunal Federal fixou a competência da Justiça do Trabalho para as ações coletivas ajuizadas para preservação do meio ambiente do trabalho; ${ }^{251} \mathrm{e}$ os Tribunais Regionais têm acolhido pedidos de medidas preventivas ambientais e de condenação no pagamento de indenização por dano moral coletivo ambiental. O posicionamento jurisprudencial, tanto em relação às medidas preventivas quanto reparadoras, será examinado de modo mais aprofundado quando do exame das formas de reparação dos danos.

Saliente-se que as decisões exaradas pela Justiça do Trabalho não têm somente a finalidade de buscar reparar danos causados aos trabalhadores, em decorrência das condições de trabalho, mas também objetivo pedagógico, na medida em que as

\footnotetext{
${ }^{250}$ Nesse sentido, a Súmula 736 do E. STF: "Compete à Justiça do Trabalho julgar as ações que tenham como causa de pedir o descumprimento de normas trabalhistas relativas à segurança, higiene e saúde dos trabalhadores" (DJ 09.12.2003).

${ }^{251}$ STF, 2. Turma, RE 206.220-1, Rel. Min. Marco Aurélio, j. 16.03.1999.
} 
condenações desestimulam práticas patronais que não primam pela proteção à vida e da segurança e saúde nas relações do trabalho.

E o Ministério Público do Trabalho (MPT), instituição incumbida da defesa da ordem jurídica, do regime democrático e dos interesses sociais e individuais indisponíveis, ganhou relevância com a Constituição de 1988. Assim, suas funções institucionais foram ampliadas, voltadas para a tutela dos direitos e interesses mais relevantes do cidadão e da sociedade, em especial a tutela do meio ambiente do trabalho, da saúde e da integridade física e psíquica dos trabalhadores, como direitos fundamentais do cidadão. ${ }^{252}$, como dispõe o artigo 129, entre as funções institucionais do MPT encontra-se a promoção do inquérito civil e da ação civil pública para a proteção do patrimônio público e social, do meio ambiente e de outros interesses difusos e coletivos, frequentes nas questões de segurança e saúde do trabalho. Ademais, a Lei Orgânica do Ministério Público da União, a Lei Complementar 75, de 20.05.1993, conferiu ao Parquet a competência para promover a Ação Civil Pública (ACP), no âmbito da Justiça do Trabalho, sendo órgão legitimado para a tutela jurisdicional na defesa de questões ligadas ao meio ambiente do trabalho.

Como ressalva Raimundo Simão de Melo, a ACP é utilizada pelo Ministério Público como último remédio, pois não se sabe do seu desfecho, tampouco o tempo de demora até a solução final da lide. Por isso, as questões relativas ao meio ambiente de trabalho são resolvidas, no mais das vezes, com Termos de Ajustamento de Conduta $(\mathrm{TAC})^{253}$ firmados com as empresas; o TAC é instrumento eficaz para a tutela da saúde e integridade física e psíquica dos trabalhadores, pois induz a adoção de providências a cargo do empregador, para correção de irregularidades, de forma a evitar eclosão de moléstias ou ocorrências de acidentes do trabalho, causadores, muitas vezes, de danos irreversíveis para os trabalhadores.

E, ressalte-se, nos momentos de crise econômica, como atualmente vivenciamos, ganha importância a atuação do Ministério Público do Trabalho na solução de conflitos sociais na área trabalhista, quando os sindicatos se veem fragilizados, em especial diante

\footnotetext{
${ }^{252}$ MELO, Raimundo Simão de. Direito ambiental do trabalho e a saúde do trabalhador: responsabilidades legais, dano material, dano moral, dano estético, indenização pela perda de uma chance, prescrição. São Paulo: LTr, 2008. p. 81.

${ }^{253}$ Idem, ibidem, p. 83.
} 
da ameaça do desemprego; esse órgão pode integrar processos de negociação coletiva, com a participação das entidades sindicais, visando à tutela do meio ambiente de trabalho.

Otavio Pinto e Silva aponta a necessidade de articular as competências do auditor fiscal com as do Ministério Público do Trabalho, destacando que os auditores desempenham suas funções nos locais onde nascem os conflitos, em contato direto com os atores da relação e por isso são privilegiados, em relação aos demais operadores do direito do trabalho; têm condições de analisar o conflito em todas as suas vertentes e avaliar a melhor forma de solucioná-lo, evitando a via judicial. Assim, conclui esse autor, uma inspeção trabalhista bem aparelhada representa condição indispensável tanto para a prevenção de conflitos de trabalho quanto para a atuação integrada com outros órgãos ou instituições, na busca da solução dos conflitos. ${ }^{254}$ Acrescente-se aqui que essa atuação, articulada com demais atores sociais, como as entidades sindicais já mencionadas, os empregadores, contando com a participação da sociedade civil, como se verá, redundará por certo na alteração do status quo, para que o trabalho seja desenvolvido em um meio ambiente sadio e equilibrado.

\subsection{O papel da sociedade civil na proteção da saúde do trabalhador}

O legislador constituinte de 1988, no processo de redemocratização do País, fez inserir na Constituição Federal mecanismos de participação social, em um movimento reverso ao que antes imperava, quando a sociedade civil esteja alijada, impedida de se manifestar acerca do seu próprio destino.

Encontramos no Capítulo VI - Do Meio Ambiente - previsão de participação da sociedade, pois, de acordo com o artigo 225 da Carta, o direito ao meio ambiente ecologicamente equilibrado, bem de uso comum do povo e essencial à sadia qualidade de vida, não é de responsabilidade tão somente do Poder Público, a coletividade tem o dever de defendê-lo e preservá-lo para a presente e futuras gerações.

\footnotetext{
${ }^{254}$ SILVA, Otavio Pinto e. Subordinação, autonomia e parassubordinação nas relações de trabalho. São
} Paulo: LTr, 2004. p. 188. 
Nesse espírito, impõe-se estimular e proporcionar uma gestão participativa do Estado, que deverá contar, na prevenção dos riscos ambientais, neles incluídos os riscos no meio ambiente de trabalho, com a inclusão dos diversos atores sociais: o chamado terceiro setor, ONGs; universidades; entidades representativas das categorias profissionais e patronais, entre outros.

Alain Wisner, em sua obra que reúne textos selecionados de ergonomia, enfoca uma forma de inteligência, como diz "aquela que não se aprende na escola", que é a que se desenvolve com a experiência, em condições reais da atividade de produção, bem como nas atividades domésticas ou nos demais afazeres do cotidiano. Segundo esse autor, sólidos estudos realizados no campo da psicologia cognitiva devem tornar-se uma das mais ativas áreas de intercâmbio entre a Universidade e a empresa, ressaltando a importância do papel da Universidade, que por meio de intercâmbios com as empresas pode aprimorar a formação dos adultos, para assentar novas escolhas organizacionais, voltadas à redução de riscos no ambiente de trabalho:

[...] numerosos e sólidos estudos que se desenvolvem no domínio da psicologia cognitiva devem tornar-se muito em breve uma das mais ativas áreas de intercâmbio entre a Universidade e a empresa, para garantir o bom êxito das novas tecnologias, reduzir o risco nos conjuntos complexos e perigosos, para dar bases sérias à formação dos adultos e para assentar as novas escolhas organizacionais. Esses intercâmbios já são muito desenvolvidos fora da França e começam a sê-lo em nosso país, em campos tão essenciais quanto a automação da fábricas, a redução das panes-erros nas redes de microcomputadores do terciário, a segurança das centrais nucleares ou dos grandes conjuntos químicos. A secção de Tecnologia, Emprego e Trabalho do Ministério da Pesquisa e da Tecnologia lançou recentemente um programa de pesquisas sobre a formação dos adultos com baixo nível de formação e de qualificação. Esse programa deveria evidenciar o aspecto fíctício de um grande número de estágios de formação atualmente dispensados por um custo financeiro exorbitante. Quando conhecemos a complexidade dos raciocínios que um operário pouco qualificado pode aplicar em seu trabalho quotidiano, dificilmente podemos aceitar a hipótese de ignorância, de tabula rasa em que se baseiam demasiadas formações. É só com base em saberes anteriores, em modelos cognitivos empregados até então que podemos fazer com que alguém evolua no uso correto de um dispositivo técnico novo. Mas para saber como alguém pensa, também é preciso se interessar por isso e, às vezes, como Feuerstein, dar-lhes as palavras para que o digam.[...]. ${ }^{255}$

${ }^{255}$ WISNER, Alain. A inteligência no trabalho: textos selecionados de ergonomia. São Paulo: Fundacentro, 1994. p. $72-73$. 
E, ao tratar do papel da Universidade, cabe lamentar a pouca importância que se dá no nosso país à formação acadêmica voltada ao conhecimento do mundo do trabalho, aí incluída a área de saúde e segurança; exemplo disso é a inexistência de curso de graduação na área de engenharia de segurança do trabalho, ministrado somente no nível de pósgraduação. E, nessa esteira, observe-se também que a formação jurídica não prima por levar ao conhecimento dos alunos a realidade dos trabalhadores, urbanos ou rurais; o estudante de direito, mesmo que tenha optado especificamente por Direito do Trabalho, conclui seu curso sem conhecer o chão da fábrica ou a realidade da lida no campo, situação que necessita ser revertida.

A defesa dos interesses difusos e coletivos, em uma sociedade civil cada vez mais consciente e participativa, exige instrumentos coletivos eficazes, como a Ação Civil Pública, que pode ser manejada inclusive por entidades associativas, pois têm legitimidade para representar seus filiados judicial e extrajudicialmente, como prevê o inciso XXI do artigo 5. ${ }^{\circ}$ da Constituição Federal.

No entanto, a garantia ao ambiente de trabalho sadio e equilibrado, que é de todos, não deve ser assegurada somente por meio de instrumentos formais ou pela via judicial: uma sociedade civil participativa e consciente pode e deve informar aos órgãos competentes denúncias de poluição ambiental, de desrespeito aos trabalhadores, como situações de trabalho degradante ou mesmo de trabalho em condições análogas à de escravo.

Recorrer à mídia, por seus diversos meios, é providência que não deve ser desprezada; empresas denunciadas por explorar mão de obra em situação degradante, por meio da televisão, jornais ou rádios, buscam tomar providências para reverter a situação denunciada, pois as denúncias veiculadas pelos meios de comunicação têm o poder de causar estragos à imagem e prejuízos financeiros.

A sociedade civil tem atualmente meios extremamente ágeis e eficazes ao seu dispor: com o avanço das diversas formas de comunicação e dos recursos tecnológicos, a utilização da internet ou das redes sociais para realização de denúncias tem se revelado como importante instrumento para reversão dos fatos denunciados, em face da rapidez e do enorme contingente de cidadãos que deles tomam conhecimento. 


\subsubsection{Das entidades sindicais}

Quando se fala que incumbe também à coletividade a defesa do meio ambiente, no âmbito trabalhista, são os sindicatos que em primeiro lugar estão incumbidos diretamente dessa tarefa.

Assim, além do papel estatal e das obrigações dos empregadores, incumbe aos sindicatos, parte da sociedade organizada, a defesa dos interesses coletivos ou individuais da categoria (artigo 8. ${ }^{\circ}$, III, CF), incluído o meio ambiente de trabalho. E os sindicatos têm a prerrogativa de representar os interesses gerais da categoria profissional perante as autoridades administrativas e judiciárias, conforme artigo 513 da CLT.

A prevenção de doenças e de acidentes de trabalho é exercida pelas Cipas, ou mesmo por trabalhadores membros de Comissões de Fábricas ou de demais comissões representativas da categoria profissional.

Aqui é preciso salientar a importância da negociação coletiva, instrumento privilegiado pela Constituição Federal, no inciso XXVI do artigo 7.', bem como nos incisos XIII e XIV deste dispositivo, onde está prevista a atuação da entidade sindical na negociação das condições laborais.

Antes da entrada em vigor da Constituição de 1988, em 1980, lembram Maria Maeno e José Carlos do Carmo, pela primeira vez foi concedida estabilidade no emprego ao trabalhador portador de doença decorrente do trabalho no Acordo Coletivo firmado pelo Sindicato dos Metalúrgicos de São Paulo. ${ }^{256}$

As negociações coletivas na área de saúde e segurança do trabalho têm sido estimuladas pelo Ministério do Trabalho e Emprego e pelo Ministério da Saúde, principalmente as negociações tripartites, com a presença de órgãos públicos, órgãos de representação dos trabalhadores e órgãos de representação dos empregadores, resultando em normas ou acordos nacionais, regionais, municipais ou convenções coletivas, ressaltam Rodolfo Vilela, Gil Vicente Fonseca e Iguti.

${ }^{256}$ MAENO, Maria; CARMO, José Carlos do. Saúde do Trabalhador no SUS: aprender com o passado, trabalhar o presente, construir o futuro. São Paulo: Hucitec, 2005. p. 61. 
Ilustram esses autores, dentre as experiências, o acordo nacional sobre utilização do benzeno, após negociação nacional tripartite, concluída em 1995, com a assinatura da Portaria 14 e Instruções Normativas 1 e 2 do Ministério do Trabalho; a convenção coletiva de segurança em máquinas injetoras de plástico do Estado de São Paulo, o acordo sobre proteção de cilindros de massa na Cidade de São Paulo e o acordo de segurança em prensas mecânicas e equipamentos similares na região da Grande São Paulo. Essas negociações são formas alternativas de solução de conflitos nas relações entre capital e trabalho, criando comissões permanentes de negociação entre as partes envolvidas. Além da solução direta dos problemas identificados, as negociações têm produzido normas e padrões de saúde e segurança, seja através da Associação Brasileira de Normas Técnicas (ABNT) ou na criação de normas de saúde e segurança dos órgãos públicos envolvidos. ${ }^{257}$

Exemplo importante da participação de entidade representativa de trabalhadores foi o protagonizado pelos sindicatos dos empregados em empresas de processamento de dados, em atuação conjunta com o Ministério do Trabalho e Emprego (MTE), como relatam Paulo Oliveira, Lys Esther Rocha, Airton Marinho da Silva, Carlos Alberto Diniz Silva e Maria de Lourdes Moure: na fase de elaboração da nova Constituição, houve aumento de demanda por fiscalização das empresas de processamento de dados, com base em denúncias de trabalhadores, em razão de uma verdadeira "epidemia" de tenossinovite ocupacional que acometia os trabalhadores, no transcurso dos anos 80. A associação nacional desses profissionais solicitou à Secretaria de Segurança e Saúde no Trabalho, do MTE, a elaboração de uma norma voltada aos integrantes dessa categoria, que limitasse a cadência de trabalho, proibisse o pagamento de prêmios de produtividade e estabelecesse critérios de conforto em relação ao mobiliário e ao ambiente de trabalho. ${ }^{258}$

Após uma negociação tripartite, com a participação de representantes dos empregadores, dos trabalhadores e do Ministério do Trabalho, foi concluída a redação da Norma Regulamentadora 17 - NR-17, publicada por meio da Portaria 3.751, de 23 de

${ }^{257}$ VILELA, Rodolfo Andrade G.; GIL VICENTE FONSECA, Ricardi; IGUTI, Aparecida Mari. Experiência do Programa de Saúde do Trabalhador de Piracicaba: desafios da vigilância em acidentes do trabalho. Inf. Epidemiol, Sus, Brasília, v. 10, n. 2, jun. 2001. Disponível em: $<$ http://scielo.iec.pa.gov.br/scielo.php?script=sci_arttext\&pid=S010416732001000200003\&lng=es\&nr =iso $>$. Acesso em: 3 ago. 2012.

${ }^{258}$ MINAYO GOMEZ, Carlos et al. (Org.). Saúde do trabalhador na sociedade brasileira contemporânea. Rio de Janeiro: Fiocruz, 2011. p. 145-146. 
novembro de 1990, a primeira experiência de modificação de norma de Saúde e Segurança com base em negociação tripartite, princípio que incorporaria tais procedimentos, como regra geral, à luz do que preconiza a OIT. Importante ressaltar que o enfoque da saúde dos trabalhadores foi incorporado à NR-17, sendo inserida no texto legal a organização do trabalho como aspecto a ser analisado na avaliação das condições de trabalho. Os autores citados, no artigo A implantação de políticas públicas de ergonomia na saúde do trabalhador: a experiência participativa do Ministério do Trabalho e Emprego, na obra organizada por Carlos Minayo Gomez, salientam que a inclusão levada a efeito na NR-17 está mais de acordo com o que se entende por ergonomia, à luz dos ensinamentos de Wisner, como um "conjunto de conhecimentos científicos relativos ao homem e necessários à concepção de ferramentas, máquinas e dispositivos que possam ser utilizados com o máximo de conforto, segurança e eficiência”.

E a respeito da negociação coletiva ambiental trabalhista impõe-se ressaltar o brilhante estudo realizado por Maria Isabel Cueva Moraes, em que sustenta sua utilização como instrumento privilegiado para tutela da saúde e segurança no trabalho, salientando que ela representa um rompimento com o modelo do direito sindical calcado no conflito coletivo de trabalho e na contraposição de interesses, na medida em que o alcance de sua proteção chega a atingir terceiros, não integrantes da categoria profissional ou econômica:

A hipótese, aliás, representa um rompimento com o modelo do direito sindical calcado no conflito coletivo de trabalho e na contraposição de interesses. Com efeito, o traço dos interesses difusos como direitos de terceira dimensão, marcados pela solidariedade (são direitos que, em princípio, todos têm o dever ou obrigação de buscar padrões para melhora ou implementação), acarreta que muitas vezes a cláusula pactuada em acordo ou convenção coletiva diga respeito a uma obrigação de não propiciar lesão a outros estranhos aos representados (integrantes da categoria profissional ou econômica) ou mesmo a pessoas completamente desconhecidas. Como exemplo, citamos a pactuação coletiva prevendo a obrigação de não vender máquinas e equipamentos que estão sendo descartados pela empresa porque possuem potencial lesivo e padrão já não aceito como seguro - evitandose, com isso, a transferência do risco de lesões para terceiros fora da relação coletiva de trabalho, em situação de maior precariedade e menor campo de atuação protetora estatal ou sindical (as chamadas empresas "de fundo de quintal", que muitas vezes se ativam em situação de 
empreendimento familiar, sem a necessidade de relação de emprego para a existência de produção). ${ }^{259}$

Nesse sentido, Otavio Pinto e Silva reporta-se às diretrizes da OIT e em particular à Convenção 154, explicitando seu alcance, que abarca todas as negociações que se realizam entre um empregador, um grupo de empregadores ou uma ou mais organizações de empregadores, de um lado, e uma ou mais organizações de trabalhadores, de outro, para, entre outros objetivos, definir condições de trabalho e termos de emprego. Trata-se de instrumento imprescindível em um Estado Democrático de Direito, para que trabalhadores e empregadores possam construir, da forma mais democrática possível, as regras para resolução de seus conflitos. ${ }^{260}$

A participação direta dos trabalhadores e de sindicatos é preconizada pela Norma Regulamentadora n. 9, itens 9.4 e 9.5, da Portaria 3.214/1978 do Ministério do Trabalho e Emprego. Dispõe tal norma que é direito dos trabalhadores apresentar propostas e receber informações e orientações a fim de assegurar a proteção aos riscos ambientais identificados nos programas de prevenção de riscos.

No entanto, no que tange à negociação de condições ambientais de trabalho no Brasil, a atuação sindical ainda é tímida; por certo recebe maior atenção e esforços do meio sindical a negociação que discute cláusulas econômicas. Ainda se verifica maior atuação sindical reivindicando pagamento de adicionais de insalubridade e de periculosidade, que sem dúvida não é o caminho a ser trilhado na defesa da saúde dos trabalhadores.

De qualquer modo, existem importantes atuações na defesa do meio ambiente de trabalho, e, para que as entidades sindicais possam cada vez mais se valer de novos institutos para a proteção dos direitos fundamentais dos trabalhadores, é importante que haja uma aproximação dos sindicatos de demais órgãos, como o Ministério Público do Trabalho, para uma atuação conjunta na defesa dos interesses indisponíveis dos trabalhadores.

${ }^{259}$ MORAES, Maria Isabel Cueva. A negociação coletiva ambiental trabalhista e seus frutos. 2008. Dissertação (Mestrado) - Faculdade de Direito da USP, São Paulo, 158.

${ }^{260}$ SILVA, Otavio Pinto e. Subordinação, autonomia e parassubordinação nas relações do trabalho. São Paulo: LTr, 2004. p. 169-171. 
Nesse sentido, a ratificação pelo Brasil da Convenção 148 da OIT, que, ao tratar da contaminação do ar, ruído e vibrações, regulamenta a participação dos trabalhadores no acompanhamento das inspeções do trabalho e na implementação das negociações tripartites, para aplicação de medidas preventivas e limitadoras de riscos profissionais, dá novo impulso à busca pela melhoria das condições de trabalho no País.

Algumas empresas sustentam que "representantes dos trabalhadores", como consta na Convenção 148, seriam os membros da Cipa, e não os dirigentes sindicais, alerta Sebastião Geraldo de Oliveira. Esse autor acertadamente entende que os dirigentes sindicais são os verdadeiros representantes dos trabalhadores e podem, com maior liberdade e independência, apontar os eventuais descumprimentos de normas de segurança e saúde do trabalho, na esteira de entendimento jurisprudencial do E. STJ. ${ }^{261}$

\subsubsection{Do empregador}

Segadas Vianna, em capítulo atualizado por Arnaldo Süssekind, valendo-se dos estudos de Pérez Botija, ressalta que a segurança do indivíduo é um dos princípios fundamentais da segurança social, mas é também uma consequência do contrato de trabalho. Assim, a forma de proteção denominada material realiza-se por meio de quatro deveres específicos do empresário: a) organização racional do trabalho; b) higiene dos locais e segurança industrial; c) prevenção de acidentes; d) reparação dos sinistros ou incapacidade. $^{262}$

Ainda nos dias atuais constata-se que os empresários preferem não investir em prevenção de acidentes. $\mathrm{O}$ que de início pode parecer economia em seguida se revela mais dispendioso, para o empregador e para a Previdência Social, pois condições inadequadas de trabalho redundam em absenteísmo, horas não trabalhadas, gastos com benefícios,

261 “Trabalhista. Convenção n. 148 da OIT. Decreto n. 93.413/1986. CLT, art. 513, 'a'. Dirigentes sindicais. 1. A representação dos trabalhadores nas inspeções de controle das medidas de proteção à saúde e à higiene dos locais de trabalho, previstas na Convenção n. 148 da Organização Internacional do Trabalho - OIT, promulgada pelo Decreto n. 93.413/1986 é prerrogativa dos dirigentes sindicais da respectiva categoria profissional, nos termos do art. 513, 'a' da Consolidação das Leis do Trabalho - CLT. 2. Recurso improvido." STJ, 2. ${ }^{\text {a }}$ Turma, REsp 84.674/SP, Rel. Min. Castro Meira, DJ 20.09.2004. OLIVEIRA, Sebastião Geraldo de. Proteção jurídica à saúde do trabalhador. 5. ed. São Paulo: LTr, 2010. p. 78.

${ }^{262}$ SÜSSEKIND, Arnaldo et al. Instituições de direito do trabalho. São Paulo: LTr, 2000. v. 2, p. 912. 
adicionais de insalubridade e periculosidade, perda de produtividade, sem contar as indenizações individuais e coletivas por danos morais e materiais, decorrentes de doenças e acidentes do trabalho. ${ }^{263}$

Observe-se que certos riscos que parecem fazer parte da natureza da atividade de trabalho poderiam ser eliminados com a simples introdução de melhorias técnicas.

O empregador, para a garantia do direito à saúde do trabalhador, tem de cumprir obrigações prescritas na Constituição Federal, nas normas infraconstitucionais, nas regulamentações, nas chamadas normas "coletivas", ou nas disposições de caráter internacional, como os tratados, convenções e recomendações.

Prevê a Constituição Federal que os empregadores são obrigados a reduzir os riscos inerentes ao trabalho, por meio de normas de saúde, higiene e segurança, nos termos do inciso XXII do artigo $7 .^{\circ}$ da Carta.

Por sua vez, a CLT, em seu Capítulo V - Da Segurança e Medicina do Trabalho , dispõe especificamente nos artigos 154 a 201 quais os direitos e obrigações inerentes aos empregados, empregadores e ao Governo no tocante à busca pela proteção à vida e promoção da segurança e saúde nas relações do trabalho. Tal obrigação é reiterada nos artigos 157 da CLT e seus incisos da CLT, que estabelece que cabe às empresas, também, instruir os empregados quanto às precauções a tomar no sentido de evitar acidentes do trabalho ou doenças ocupacionais. ${ }^{264}$

Nesse sentido, dispõe a NR-01 da Portaria 3.214/1978 que elenca as disposições gerais, que as Normas Regulamentadoras, relativas à segurança e medicina do trabalho, são

${ }^{263}$ Raimundo Simão de Melo comenta em Direito ambiental do trabalho e a saúde do trabalhador a palestra proferida por G. F. Scannell, no XV Congresso Mundial sobre Segurança e Saúde no Trabalho, realizado no período de 12 a 16 de abril de 1999, no Anhembi, São Paulo, Capital, com o tema "Prevenção dá lucro", em que exemplificou com pesquisa realizada pela empresa Johnson \& Johnson, que demonstrou que para dólar investido em saúde e segurança, havia uma economia de US\$ 9, que seriam desperdiçados em pagamento de benefícios, perdas de produtividade etc. (p. 61).

264 “Cabe às empresas: I - cumprir e fazer cumprir as normas de segurança e medicina do trabalho; II instruir os empregados, através de ordens de serviço, quanto às precauções a tomar no sentido de evitar acidentes do trabalho ou doenças ocupacionais; III - adotar as medidas que lhe sejam determinadas pelo órgão regional competente; IV - facilitar o exercício da fiscalização pela autoridade competente." 
de observância obrigatória pelas empresas privadas e públicas e pelos órgãos públicos da administração direta e indireta, bem como pelos órgãos dos Poderes Legislativo e Judiciário, que possuam empregados regidos pela CLT. E tal norma regulamentadora prevê no seu item 1.7 que cabe ao empregador:

a) cumprir e fazer cumprir as disposições legais e regulamentares sobre segurança e medicina do trabalho; (101.001-8/I1)

b) elaborar ordens de serviço sobre segurança e medicina do trabalho, dando ciência aos empregados, com os seguintes objetivos: (101.0026/I1)

I - prevenir atos inseguros no desempenho do trabalho;

II - divulgar as obrigações e proibições que os empregados devam conhecer e cumprir;

III - dar conhecimento aos empregados de que serão passíveis de punição, pelo descumprimento das ordens de serviço expedidas;

IV - determinar os procedimentos que deverão ser adotados em caso de acidente do trabalho e doenças profissionais ou do trabalho;

$\mathrm{V}$ - adotar medidas determinadas pelo MTb;

VI - adotar medidas para eliminar ou neutralizar a insalubridade e as condições inseguras de trabalho.

c) informar aos trabalhadores: (101.003-4 / I1)

I - os riscos profissionais que possam originar-se nos locais de trabalho;

II - os meios para prevenir e limitar tais riscos e as medidas adotadas pela empresa;

III - os resultados dos exames médicos e de exames complementares de diagnóstico aos quais os próprios trabalhadores forem submetidos;

IV - os resultados das avaliações ambientais realizadas nos locais de trabalho.

d) permitir que representantes dos trabalhadores acompanhem a fiscalização dos preceitos legais e regulamentares sobre segurança e medicina do trabalho $(101.004-2 / \mathrm{I} 1){ }^{265}$

Além disso, os empregadores se obrigam a não exigir prestação de trabalho noturno, perigoso ou insalubre a menores de 18 anos (artigo $7 .^{\circ}, \mathrm{XXXIII,} \mathrm{CF).}$

Raimundo Simão de Melo identifica três tipos de comportamento empresarial, no que se refere à proteção da saúde do trabalhador: a) no primeiro estão os ignorantes, que desconhecem os riscos ambientais e regras de prevenção e colocam muitas vezes a sua

${ }^{265}$ Disponível em: <http://www010.dataprev.gov.br/sislex/paginas/05/mtb/1.htm> Acesso em: 16 ago. 2012. 
própria vida em perigo; exemplifica com os pequenos produtores rurais, que explora produção familiar; as condições de trabalho são inseguras, e é comum haver trabalho infantil e exposição a agrotóxicos, muitas vezes proibidos; b) aqueles que só querem lucrar a qualquer custo e mesmo sabendo dos riscos iminentes e da possibilidade de ter de arcar com reparações, nada investem; e c) a última categoria é dos racionais, que analisam friamente as possibilidades de lucro, com ou sem investimento na prevenção; constata-se o aumento deste tipo no mundo capitalista, pois investir na prevenção da saúde não somente evita gastos, como dá lucro. ${ }^{266}$

\subsubsection{Da Comissão Interna de Prevenção de Acidentes - Cipa}

A Comissão Interna de Prevenção de Acidentes (Cipa) é órgão de representação paritária, formado por representantes dos empregadores e dos empregados, de constituição obrigatória nos termos do artigo 163 da CLT; e, na forma do artigo 164 consolidado e seus parágrafos, os representantes dos empregadores, titulares e suplentes, serão por eles designados; já os que representam os empregados serão eleitos, tanto os titulares quanto os suplentes.

Ensina Fábio Fernandes que a Cipa surgiu entre nós com o diploma normativo que tratava de acidente do trabalho - o Decreto-lei 7.036/1944 - com obrigatoriedade restrita às empresas com mais de 100 empregados; e, em 1967, com o advento do Decretolei 229, de 28.02.1967, foi transportada para a CLT, em que é regulada nos artigos 163 a $165 .^{267}$

A configuração desse órgão de prevenção de acidentes foi aperfeiçoada com a entrada em vigor da Lei 6.514/1977, que deu nova redação ao Capítulo V da CLT, prevendo, no artigo 200, que cabe ao Ministério do Trabalho estabelecer disposições complementares às normas do Capítulo, considerando-se as peculiaridades de cada

\footnotetext{
${ }^{266}$ MELO, Raimundo Simão de. Direito ambiental do trabalho e a saúde do trabalhador: responsabilidades legais, dano material, dano moral, dano estético, indenização pela perda de uma chance, prescrição. São Paulo: LTr, 2008. p. 61-62.

${ }^{267}$ FERNANDES, Fábio. Meio ambiente geral e meio ambiente do trabalho: uma visão sistêmica. São Paulo: LTr, 2009. p. 209.
} 
atividade ou setor de trabalho; possibilitou, assim, a edição da Portaria 3.214/1978 que aprovou, entre outras, a Norma Regulamentadora 5 - NR5, que regulamenta a Cipa.

Esse órgão não está vinculado à estrutura sindical, pois, como prevê o $§ 2 .^{\circ}$ do artigo 164 da CLT, "Os representantes dos empregados, titulares e suplentes, serão eleitos em escrutínio secreto, do qual participem, independentemente de filiação sindical, exclusivamente os empregados interessados", disposição reiterada na própria NR5.

Como disciplina o item 5.2 dessa Norma Regulamentadora, as Cipas devem ser constituídas por estabelecimento. Sua composição é dimensionada pelo Quadro I anexo à NR5, de acordo com o número de trabalhadores por estabelecimento e grau de risco da empresa, sendo obrigatória nos estabelecimentos ou locais de obra em que trabalhem 20 trabalhadores ou mais; nos locais de trabalho com número inferior de obreiros, a empresa deverá designar um responsável pelo cumprimento dos objetivos dessa NR, podendo ser adotados mecanismos de participação dos empregados, por meio de negociação coletiva, como prevê o item 5.6.4 da NR5.

Devem constituir a Cipa e mantê-la em regular funcionamento as empresas privadas, públicas, sociedades de economia mista, órgãos da administração direta e indireta, instituições beneficentes, associações recreativas, cooperativas, bem como outras instituições que admitam trabalhadores como empregados, nos expressos termos do item 5.3 dessa NR.

A Cipa tem como objetivo a prevenção de acidentes e doenças decorrentes do trabalho, de modo a tornar compatível permanentemente o trabalho com a preservação da vida e a promoção da saúde do trabalhador, de acordo com disposição literal do item 5.1 da NR5.

As atribuições da Cipa estão dispostas e elencadas no item 5.6 dessa Norma Regulamentadora, destacando-se, dentre elas: identificar os riscos do processo de trabalho e elaborar o mapa de riscos, com a participação do maior número de trabalhadores, com assessoria do Serviço Especializado em Engenharia de Segurança e em Medicina do Trabalho (SESMT), onde houver; elaborar plano de trabalho que possibilite a ação preventiva na solução de problemas de segurança e saúde no trabalho; participar da 
implementação e do controle da qualidade das medidas de prevenção necessárias; deverá ainda participar da avaliação das prioridades de ação nos locais de trabalho; realizar, periodicamente, verificações nos ambientes e condições de trabalho visando a identificação de situações que venham a trazer riscos; avaliar a cada reunião o cumprimento das metas fixadas em seu plano de trabalho, e discutir as situações de risco identificadas; divulgar aos trabalhadores informações relativas à segurança e saúde no trabalho; participar com o SESMT das discussões promovidas pelo empregador, para avaliar os impactos de alterações no ambiente e processo de trabalho; requerer ao SESMT ou ao empregador a paralisação de máquina ou setor em que considere haver risco grave e iminente à segurança e saúde dos trabalhadores; colaborar no desenvolvimento e implementação do Programa de Controle Médico de Saúde Ocupacional (PCMSO) e Programa de Prevenção de Riscos Ambientais (PPRA) e de outros programas relacionados à segurança e saúde no trabalho; divulgar e promover o cumprimento das Normas Regulamentadoras, bem como cláusulas de acordos e convenções coletivas de trabalho, relativas à segurança e saúde no trabalho; requisitar ao empregador informações e cópias de Comunicações de Acidentes de Trabalho (CAT) emitidas; promover, anualmente, em conjunto com o SESMT, a Semana Interna de Prevenção de Acidentes do Trabalho (Sipat).

Esse elenco de atribuições, no entanto, restringe-se aos aspectos físicos do ambiente de trabalho, com foco nas questões que envolvem diretamente a saúde e a integridade física dos trabalhadores, e por isso a atuação da Cipa é limitada, como comenta Nadia Demoliner Lacerda, pois não abarca aspectos da organização do trabalho, como excesso de horas extras e turnos de revezamento. ${ }^{268}$ Assim, as Cipas não atuam nos demais fatores da relação de trabalho que também afetam a saúde dos trabalhadores, por exemplo, autoritarismo de chefias, cobranças excessivas por metas, práticas de assédio moral etc.

De qualquer forma, avanços ocorrem, como o promovido pela Portaria 25, de 29.12.1994, da Secretaria de Segurança e Saúde no Trabalho (SSST) do Ministério do Trabalho, que aprovou o texto da Norma Regulamentadora 9 - Riscos Ambientais - e inovou ao atribuir à Cipa, depois de ouvidos os trabalhadores de todos os setores do estabelecimento e com a colaboração do SESMT, a elaboração do Mapa de Riscos, com a

${ }^{268}$ LACERDA, Nadia Demoliner. Segurança e saúde do trabalhador: para onde vamos? O debate nacional sobre a concepção preventiva do novo seguro de acidente. São Paulo: LTr, 2011. p. 92-93. 
finalidade de identificar todos os riscos existentes no ambiente de trabalho, o que deverá ser refeito a cada nova gestão da Cipa.

É preciso registrar, contudo, que a maioria das Cipa e SESMT existe somente no papel, para cumprir uma formalidade legal, especialmente nas pequenas e médias empresas, como ressalta com propriedade Sebastião Geraldo de Oliveira. E os empresários em geral não incluem as políticas de prevenção de acidentes e promoção da saúde do trabalhador como um item importante do negócio; cumprem a lei por obrigação, para evitar problemas com a fiscalização; assim, as empresas procuram demonstrar o cumprimento formal da lei, mas não incorporam efetivamente as práticas prevencionistas. ${ }^{269}$

Existem, no entanto, experiências positivas no Brasil e que merecem destaque. $\mathrm{O}$ movimento sindical da região do $\mathrm{ABC}$ paulista, que concentrava, na década de 70 , as grandes montadoras, inspirado nas experiências da Itália e da Alemanha, que já possuíam comissões internas de representação dos trabalhadores de natureza sindical e não sindical, procurou inovar na representação no chamado "chão de fábrica". Assim, foi constituída na Ford, na década de 70, a primeira Comissão de Fábrica, seguidas depois pelas Comissões de Fábrica da Volkswagen e da Mercedes, na década de $80 .{ }^{270}$

Merece destaque também a experiência de constituição do Sistema Único de Representação (SUR), depois denominado de Comitê de Representação Interna dos Empregados, criado por Acordo Coletivo firmado entre o Sindicato dos Metalúrgicos do ABC e a Scania, em 1996, com posteriores renovações. Trata-se de sistema de representação dos trabalhadores que absorveu o papel da Cipa, desestruturando a composição paritária inerente à comissão, como ressalta Maria Isabel Cueva Moraes. ${ }^{271}$

O então denominado SUR, atualmente, é uma fusão da Cipa, da Comissão de Fábrica e do comitê sindical, em que os membros são eleitos pelos empregados filiados ao Sindicato, com mandato de três anos. Essa representação interna única cuida das questões

${ }^{269}$ OLIVEIRA, Sebastião Geraldo de. Proteção jurídica à saúde do trabalhador. 5. ed. São Paulo: LTr, 2010. p. 137.

${ }^{270}$ LACERDA, Nadia Demoliner. Segurança e saúde do trabalhador: para onde vamos? O debate nacional sobre a concepção preventiva do novo seguro de acidente. São Paulo: LTr, 2011. p. 93.

${ }^{271}$ MORAES, Maria Isabel Cueva Moraes. A negociação coletiva ambiental trabalhista e seus frutos. 2008. Dissertação (Mestrado) - Faculdade de Direito da USP, São Paulo, p. 105. 
cotidianas referentes a todos os aspectos da relação de trabalho, nos respectivos setores do trabalho, destaca Nadia Demoliner Lacerda. Neste tipo de representação, adotado por outras montadoras, a participação efetiva dos trabalhadores tem sido alcançada, inclusive, no que diz respeito às questões de saúde e segurança dos trabalhadores, com excelentes resultados.

Trata-se de exemplo concreto de que, se houver de fato vontade do empregador em concretizar política de prevenção de acidentes e promoção da saúde dos trabalhadores, na acepção mais ampla, que somente pode ser levada a cabo com a efetiva participação dos empregados e de suas entidades representativas, todos saem ganhando.

\subsubsection{Serviços Especializados em Engenharia de Segurança e em Medicina do Trabalho -} SESMT

De acordo com o previsto no artigo 162 da CLT, as empresas, conforme as normas a serem expedidas pelo Ministério do Trabalho, estarão obrigadas a manter serviços especializados em segurança e em medicina do trabalho, que deverão classificar as empresas segundo o número mínimo de empregados e natureza do risco de suas atividades; indicar a composição mínima de profissionais especializados por empresa, de acordo com o grau de risco, bem como sua qualificação, regime de trabalho e demais características e atribuições dos SESMTS nas empresas.

Tais serviços foram regulamentados pela NR 4, aprovada pela Portaria 33, de 27.10.1983, alterada pela Portaria 17, 1. ${ }^{\circ} .08 .2007$, do Ministério do Trabalho e Emprego, que determina que as empresas privadas e públicas, os órgãos públicos da administração direta e indireta e dos Poderes Legislativo e Judiciário, que possuam empregados regidos pela CLT, manterão, obrigatoriamente, Serviços Especializados em Engenharia de Segurança e em Medicina do Trabalho, com a finalidade de promover a saúde e proteger a integridade do trabalhador no local de trabalho, nos termos do item 4.1 dessa NR.

Os SESMTS serão dimensionados de acordo com a gradação do risco da atividade principal das empresas e o número total de empregados do estabelecimento; assim, a partir do mínimo de 50 empregados e conforme o grau de risco, é estabelecida a composição do SESMT, constante dos Quadros I e II, anexos à NR. 
Tais serviços têm a finalidade de promover a saúde e proteger a integridade do trabalhador no local de trabalho e devem ser integrados por engenheiro de segurança do trabalho, médico do trabalho, enfermeiro do trabalho, técnico de segurança do trabalho e auxiliar de enfermagem do trabalho.

Compete aos SESMTs, entre outras atribuições, aplicar os conhecimentos de engenharia de segurança e de medicina do trabalho ao ambiente de trabalho e a todos os seus componentes, inclusive máquinas e equipamentos, de modo a reduzir até eliminar os riscos ali existentes à saúde do trabalhador (item 4.12, letra "a").

Sempre que uma empresa contratar outra para prestar serviços nos seus estabelecimentos, deverá estender a assistência de seus Serviços Especializados em Engenharia de Segurança e em Medicina do Trabalho aos empregados da contratada, sempre que o número de empregados desta exercendo atividade naqueles estabelecimentos não alcançar os limites previstos no Quadro II, conforme item 4.5 da NR 4.

Tais serviços têm previsão normativa no âmbito internacional, pois a Convenção 161 da OIT dispõe sobre "Serviços de Saúde no Trabalho"; tal diploma foi ratificado pelo Brasil em 18.05.1990. Assim, a constituição e manutenção dos SESMTs nas empresas decorrem também da obrigação oriunda dessa ratificação; os Estados-Membros devem instituir serviços de saúde com enfoque preventivo e multidisciplinar.

Observe-se aqui que a NR foi alterada pela Portaria MTE 157, publicada em 02.08.2007. No entanto, Sebastião Geraldo de Oliveira sustenta que a regulamentação atual do SESMT está ultrapassada, pois não acompanhou as inovações legais ocorridas e não abrange todas as previsões da Convenção 161 da OIT. Tais defasagens são ilustradas por esse autor:

O SESMT não tem apenas competência para esclarecer e conscientizar os empregados sobre os acidentes do trabalho e riscos ocupacionais. Agora, pelo que dispõe o art. $19, \S 3 .^{\circ}$, da Lei n. 8.213/91, é dever da empresa prestar informações pormenorizadas sobre os riscos da operação a executar e do produto a manipular. No mesmo sentido, prevê o art. 13 da Convenção n. 161 da OIT que todos os trabalhadores devem ser informados dos riscos para a saúde inerentes ao seu trabalho. Como se vê, a informação pormenorizada dos riscos ao trabalhador não é mera faculdade do SESMT, tendo passado a ser obrigação, em reforço do que prevê o art. 157, II, da CLT. Vale enfatizar que os componentes do 
SESMT, obrigatoriamente especialistas, estão habilitados para prestar informações seguras dos riscos e das medidas preventivas.

Outra finalidade do SESMT, prevista na Convenção n. 161 da OIT, é a de promover a "adaptação do trabalho às capacidades dos trabalhadores", atribuição esta que não consta da NR-4. O preceito citado é de fundamental importância, porque o alvo passa a ser a valorização do trabalhador, já que os instrumentos, a organização e os métodos operacionais é que devem ser a ele adaptados, em vez de adaptar o trabalhador ao trabalho. ${ }^{272}$

Outra observação feita por Sebastião Geraldo de Oliveira, prevista no artigo $8 .^{\circ}$ da Convenção 161 da OIT, e consentânea como princípio da participação, é no sentido de que os trabalhadores e seus representantes devem cooperar e participar da organização dos serviços de saúde no trabalho. Por essa razão, diversos países já adotaram os "comitês de segurança e saúde", com participação dos trabalhadores ou de membros por eles indicados, com autonomia até para interromper o trabalho, quando estiverem expostos a riscos. E, na conformação atual prevista pela NR 4, somente o empregador organiza e indica os componentes do SESMT, sem participação do trabalhador.

E a falta de participação dos integrantes do SESMT, especialmente com enfoque preventivo nos processos de produção e nas questões que afetam a saúde do trabalhador, é criticada por Edith Seligmann Silva. A autora observa que no setor privado os SESMTs das empresas brasileiras ocupam uma posição geralmente distanciada dos núcleos onde são tomadas as decisões referentes aos processos de produção e ao trabalho humano. Afirma que em geral os profissionais da saúde têm pouca oportunidade de se manifestar sobre a gestão e as formas de controle exercidas sobre os trabalhadores. Sustenta que os profissionais da saúde, ao lado dos engenheiros de segurança e ergonomistas, deveriam participar dos processos decisórios referentes a transformações organizacionais e introdução de inovações, eventualmente dotadas de potencial agressivo à saúde geral e mental. $^{273}$

Saliente-se que, se os engenheiros de segurança, os ergonomistas e os profissionais de saúde efetivamente fossem ouvidos e de fato atendidas suas

${ }^{272}$ OLIVEIRA, Sebastião Geraldo de. Proteção jurídica à saúde do trabalhador. 5. ed. São Paulo: LTr, 2010. p. 380-381.

${ }^{273}$ SILVA, Edith Seligmann. Trabalho e desgaste mental: o direito de ser dono de si mesmo. São Paulo: Cortez, 2011. p. 311. 
recomendações quando as instalações ou as mudanças organizacionais estão ainda na fase de projeto, aí, sim, estariam sendo observados os princípios da prevenção e da precaução; muitos acidentes de trabalho e doenças de origem ocupacional seriam evitados, com ganho para o empregador e para os trabalhadores e inestimável ganho social.

\subsubsection{Programa de Controle Médico de Saúde Ocupacional - PCMSO}

Trata-se também de programa de implantação obrigatória, previsto na Norma Regulamentadora 7 da Portaria 3.214/78 - NR 7, que estabelece a obrigatoriedade de elaboração e implementação, por parte de todos os empregadores e instituições que admitam trabalhadores como empregados, do Programa de Controle Médico de Saúde Ocupacional (PCMSO), com o objetivo de promoção e preservação da saúde do conjunto dos seus trabalhadores.

De acordo com o previsto no item 7.2.3 da NR 7, o PCMSO deverá ter caráter de prevenção, rastreamento e diagnóstico precoce dos agravos à saúde relacionados ao trabalho, inclusive de natureza subclínica, além da constatação da existência de casos de doenças profissionais ou danos irreversíveis à saúde dos trabalhadores. O PCMSO deverá considerar as questões incidentes sobre o indivíduo e a coletividade de trabalhadores, privilegiando o instrumental clínico-epidemiológico na abordagem da relação entre sua saúde e o trabalho (item 7.2.2), e deverá ser planejado e implantado com base nos riscos à saúde dos trabalhadores, especialmente os identificados nas avaliações previstas nas demais NR.

O PCMSO deve incluir, entre outros, a realização obrigatória dos exames médicos admissional, periódico, de retorno ao trabalho, de mudança de função e demissional.

A NR 7 regulamenta a previsão legal disposta nos artigos 168 e 169 da CLT, bem como as diretrizes contidas na Convenção 161 da OIT; e os exames médicos exigidos têm a finalidade de manter um controle sanitário permanente de natureza epidemiológica no ambiente de trabalho.

O exame periódico é exigido a cada semestre, ano ou biênio, de acordo com a natureza do risco. Para trabalhadores expostos a riscos ou a situações de trabalho que 
impliquem o desencadeamento ou agravamento de doença ocupacional, ou, ainda, para aqueles que sejam portadores de doenças crônicas, os exames deverão ser repetidos a cada ano ou a intervalos menores, a critério do médico encarregado, ou se notificado pelo médico agente da inspeção do trabalho, ou, ainda, como resultado de negociação coletiva de trabalho (item 7.4.3.2 e alínea "a”).

Para cada exame realizado, o médico emitirá o Atestado de Saúde Ocupacional (ASO), informando se o trabalhador está apto ou não para o exercício da função, fornecendo-lhe cópia (item 7.4.4.2). Quando o médico coordenador perceber, nos exames realizados, a exposição excessiva ao risco, poderá determinar o afastamento do trabalhador do local de trabalho ou mesmo o afastamento do trabalho (item 7.4.7).

Constatada a ocorrência ou agravamento de doenças profissionais, caberá ao médico coordenador ou encarregado:

a) solicitar à empresa a emissão da Comunicação de Acidente do Trabalho - CAT;

b) indicar, quando necessário, o afastamento do trabalhador da exposição ao risco, ou do trabalho;

c) encaminhar o trabalhador à Previdência Social para estabelecimento de nexo causal, avaliação de incapacidade e definição da conduta previdenciária em relação ao trabalho;

d) orientar o empregador quanto à necessidade de adoção de medidas de controle no ambiente de trabalho. ${ }^{274}$

Como mencionado em tópico anterior, muitas Cipas constam somente no papel, não atuam verdadeiramente na proteção da saúde do trabalhador. Da mesma forma, tanto o PCMSO quanto o PPRA, que a seguir será examinado, são documentos de elaboração obrigatória e devem ficar à disposição da fiscalização. Comentamos anteriormente também quanto às dificuldades na realização da fiscalização, tanto pelo número insuficiente de auditores fiscais integrantes do quadro do Ministério do Trabalho quanto pela falta de estrutura necessária a uma fiscalização eficaz e abrangente, em todo o território nacional. Não é raro constatar que o PCMSO, ora sob exame, não passa de um documento destinado ao cumprimento de formalidade burocrática, sem ressonância com atitudes reais de

\footnotetext{
${ }^{274}$ Norma Regulamentadora 7 da Portaria 3.214/1978, item 7.4.8.
} 
prevenção ambiental, e sem correspondência com a realidade fática, no tocante à exposição a riscos ou a eclosão de moléstias de origem ocupacional.

Não fosse assim, não teríamos a chamada subnotificação de acidentes do trabalho, tampouco acidentes sem expedição de CAT. ${ }^{275}$

\subsubsection{Programa de Prevenção de Riscos Ambientais - PPRA}

O PPRA é um programa regulamentado pela NR 9 da Portaria 3.214/1978, que estabelece a obrigatoriedade da elaboração e implementação, por parte de todos os empregadores e instituições que admitam trabalhadores como empregados, do Programa de Prevenção de Riscos Ambientais (PPRA), visando à preservação da saúde e da integridade

275 "Desde 1970, quando começam os registros sistemáticos em âmbito nacional, mais de 30 milhões de acidentes foram notificados, registrando-se mais de 100 mil óbitos absolutamente evitáveis entre trabalhadores jovens e produtivos. Um obstáculo para o planejamento e implementação de políticas de prevenção de acidentes do trabalho é a pequena validade dessas informações, contestadas por grande número de autores. Um dos aspectos problemáticos das informações disponíveis é que elas referem-se apenas a uma parcela dos trabalhadores do mercado formal da economia. As estatísticas oficiais brasileiras de acidentes do trabalho são elaboradas a partir das informações obtidas no documento denominado Comunicação de Acidente do Trabalho (CAT), desenvolvido pela Previdência Social com fins securitários. A emissão da CAT registra e reconhece oficialmente o acidente, estabelecendo o direito do trabalhador ao seguro acidentário junto ao Instituto Nacional de Seguridade Social (INSS). Mesmo que esse documento fosse preenchido em $100 \%$ das vezes em que a lei determina, ainda assim o subregistro de acidentes do trabalho seria grande. Isso porque, segundo o Plano de Benefícios da Previdência Social, não se enquadram na obrigatoriedade da emissão da CAT funcionários públicos civis e militares estatutários, trabalhadores previdenciários autônomos, empregados domésticos e proprietários.

Para os empregados enquadrados na obrigatoriedade de emissão da CAT - trabalhadores 'celetistas' (com registro em carteira de trabalho regulamentado pela Consolidação das Leis do Trabalho) perfazendo cerca de $25 \%$ da força de trabalho - o fluxo desse documento até seu registro no INSS depende:

a) em grande parte, de ato voluntário de sua emissão pelo empregador;

b) do preenchimento do atestado médico contido no item II da CAT pelo médico de atendimento;

c) do seu encaminhamento à agência do INSS da área de ocorrência do acidente.

A subnotificação de acidentes entre trabalhadores do mercado formal é apenas um aspecto da dificuldade em se obter informações válidas sobre os acidentes do trabalho no Brasil. Soma-se a ele o total desconhecimento sobre o que acontece no setor informal da economia brasileira, sobre o qual não existe nenhum sistema de informação, em que pese abranger esse setor cerca de $60 \%$ da população brasileira economicamente ativa (PEA) nos dias atuais. O Poder Público, em seus diferentes níveis, tem como uma de suas atribuições o controle dos acidentes do trabalho e a preservação e promoção da saúde da população trabalhadora. A formulação de políticas públicas para o enfrentamento dessa questão requer informações confiáveis sobre a distribuição, caracterização e determinantes dos acidentes do trabalho" (CORDEIRO, Ricardo et al. Subnotificação de acidentes do trabalho não fatais em Botucatu, SP, 2002. Rev. Saúde Pública, São Paulo, v. 39, n. 2, abr. 2005. Disponível em: $<$ http://www.scielo.br/scielo.php?script=sci_arttext\&pid=S003489102005000200017\&lng=en\&nrm=iso> Acesso em: 18 ago. 2012). 
dos trabalhadores, mediante a antecipação, reconhecimento, avaliação e consequente controle da ocorrência de riscos ambientais existentes ou que venham a existir no ambiente de trabalho, tendo em consideração a proteção do meio ambiente e dos recursos naturais, nos termos do item 9.1.1.

As ações do PPRA devem ser desenvolvidas no âmbito de cada estabelecimento da empresa, sob a responsabilidade do empregador, com a participação dos trabalhadores, como prevê o item 9.1.2.; os parâmetros mínimos e diretrizes gerais a serem observados na execução do PPRA podem ser ampliados mediante negociação coletiva de trabalho (item 9.1.4)

O Programa de Prevenção de Riscos Ambientais deverá incluir as seguintes etapas: antecipação e reconhecimento dos riscos; avaliação dos riscos e da exposição dos trabalhadores; estabelecimento de prioridades e metas de avaliação e controle; implantação de medidas de controle e avaliação de sua eficácia; monitoramento da exposição aos riscos; registro e divulgação dos dados.

O PPRA deverá ser elaborado de forma articulada com as previsões das demais Normas Regulamentadoras, em especial com o Programa de Controle Médico e Saúde Ocupacional (PCMSO); deve ser observada a interação com a Cipa, bem como a possibilidade de atuação do SESMT.

Esse programa prevê a realização de estudo para desenvolvimento e implantação de medidas de proteção coletiva, que deverá ser acompanhada de treinamento dos trabalhadores. Tais medidas deverão atender às seguintes prioridades: as que eliminam ou reduzam a utilização ou a formação de agentes prejudiciais à saúde; medidas que previnam a liberação ou disseminação desses agentes prejudiciais à saúde; trabalho; e medidas que reduzam os níveis ou a concentração desses agentes no ambiente de trabalho (9.3.5.2 e 9.3.5.3).

A NR 9 prevê ainda que, se comprovada pelo empregador ou instituição a inviabilidade técnica da adoção de medidas de proteção coletiva ou quando estas não forem suficientes ou se encontrarem em fase de estudo, planejamento ou implantação. ou ainda em caráter complementar ou emergencial, deverão ser adotadas outras medidas 
obedecendo-se à seguinte hierarquia: medidas de caráter administrativo ou de organização do trabalho; utilização de Equipamento de Proteção Individual (EPI).

Ressalte-se que a simples elaboração do PPRA não tem o condão de comprovar que o empregador adota efetivamente medidas preventivas e protetivas da saúde dos seus empregados.

Cabe destacar que no Estado de São Paulo, por força da Lei 9.505, de 11 de março de 1997, que disciplina as ações e os serviços de saúde dos trabalhadores no Sistema Único de Saúde, os empregadores, públicos ou privados, estão obrigados a submeter também à aprovação da autoridade local do SUS e das Cipas existentes anualmente o Programa de Controle Médico de Saúde Ocupacional, o Programa de Controle do Meio Ambiente de Trabalho e o Programa de prevenção de Riscos Ambientais (artigo 11, inciso VI).

\subsection{A concepção de eliminação dos riscos nos demais países - exemplos da Europa e dos Estados Unidos da América}

As normas internacionais mais recentes, em uma trajetória inversa do que antes vigorava, da adaptação do homem ao trabalho, apontam na direção de que o primeiro a ser considerado no ambiente de trabalho é o homem, depois é que se acrescentam os equipamentos, as condições de trabalho e os métodos de produção. ${ }^{276}$

Nesse sentido, a Convenção 155 da OIT estabelece que a política nacional de saúde dos trabalhadores deve adaptar o maquinário, os equipamentos, a organização do trabalho às capacidades físicas e mentais dos trabalhadores. Impõe obrigações ao empregador, e, em caso de perigo grave e iminente, assegura ao trabalhador o direito de afastamento do local de trabalho em situação de risco:

[...] o trabalhador informará imediatamente o seu superior hierárquico direto sobre qualquer situação de trabalho que, a seu ver e por motivos razoáveis, envolva um perigo iminente e grave para sua vida ou sua saúde; enquanto o empregador não tiver tomado medidas corretivas, se forem necessárias, não poderá exigir dos trabalhadores a sua volta a uma

${ }^{276}$ OLIVEIRA, Sebastião Geraldo de. Proteção jurídica à saúde do trabalhador. 5. ed. São Paulo: LTr, 2010. p. 93. 
situação de trabalho onde exista, em caráter contínuo, um perigo grave ou iminente para sua vida ou sua saúde. ${ }^{277}$

Na mesma linha, a Convenção 161 da OIT, no seu artigo 5. ${ }^{\circ}$, alínea "g”, prevê que os serviços de saúde na empresa devem promover a adaptação do trabalho aos trabalhadores.

E a Convenção 148 da OIT, que trata da contaminação do ar, ruído e vibrações, ratificada pelo Brasil em 1982, ao dispor sobre as medidas de prevenção e proteção, prevê que

[...] os limites de exposição deverão ser fixados [...] a intervalos regulares, de conformidade com os novos conhecimentos e dados nacionais e internacionais, tendo em conta [...] qualquer aumento dos riscos profissionais resultante da exposição simultânea a vários fatores nocivos no local de trabalho.

A Convenção 187 promove o desenvolvimento de uma "cultura de prevenção em matéria de segurança e saúde" por meio do lugar de destaque concedido a estas questões nas agendas nacionais ao lançar programas nacionais de saúde e segurança no trabalho, bem como a promoção de ambientes de trabalho mais seguros e saudáveis graças a medidas preventivas. A ratificação mundial da Convenção 187 seria um avanço concreto para criar locais de trabalho mais seguros e saudáveis para todos os trabalhadores, no entanto tal convenção ainda não foi ratificada pelo Brasil.

De acordo com a OIT, há quatro modalidades principais de prevenção contra os agentes danosos: a) eliminação do risco; b) eliminação da exposição do trabalhador ao risco; c) isolamento do risco; d) proteção do trabalhador. ${ }^{278}$

$\mathrm{Na}$ União Europeia é farto o arcabouço normativo voltado à prevenção, à eliminação dos riscos e à proteção da saúde dos trabalhadores, e os instrumentos normativos nesse sentido não são recentes.

\footnotetext{
${ }^{277}$ Disponível em: < http://www.oitbrasil.org.br/node/504>. Acesso em: 18 ago. 2012.

${ }^{278}$ Introducción a las condiciones y el medio ambiente de trabajo. Disponível em: <http://www.ilo. org/wcmsp5/groups/public/ed_protect/protrav/safework/documents/normativeinstrument/wcms_112655.p df $>$. Acesso em: 18 ago. 2012.
} 
Iniciando pela Itália, a Lei 300, de 1970, o "Statuto dei lavoratori”, permite que os trabalhadores, por meio de suas representações, tenham direito de controlar a aplicação das normas para prevenção de acidentes do trabalho e das doenças profissionais e de promover as pesquisas, a elaboração e a atuação de todas as medidas capazes de tutelar sua saúde e sua integridade física.

A Diretiva 89/391 prevê a obrigação do empresário de informar a todos os trabalhadores sobre os riscos a que possam estar expostos, bem como que deverão formular consultas aos trabalhadores ou a seus representantes a respeito de todas as questões que afetam a segurança e saúde no trabalho. A norma esclarece que os próprios trabalhadores poderão formular propostas quanto à matéria. ${ }^{279}$

Sebastião Geraldo de Oliveira realiza extensa pesquisa no direito comparado, explanando sobre as normas de proteção à saúde dos trabalhadores. Dentre outros, transcreve documento da União Europeia que estabelece a "Estratégia comunitária para a saúde e a segurança no trabalho 2007-2012" e prevê no item 7 que as prioridades da investigação científica devem incluir questões psicossociais, afecções de ordem musculoesquelética, substâncias perigosas, conhecimento de riscos para a fertilidade, saúde profissional e gestão de segurança, riscos associados a vários fatores cruzados (por exemplo, organização do trabalho e questões de design do local de trabalho, ergonomia, exposição combinada a agentes físicos e químicos) e riscos potenciais associados às nanotecnologias. $^{280}$

Menciona esse autor que na Noruega a lei determina que o ambiente de trabalho deverá ser completamente satisfatório, tanto do ponto de vista individual como de uma avaliação global dos fatores capazes de afetar a saúde e o bem-estar físico e mental do trabalhador. ${ }^{281}$

\footnotetext{
${ }^{279}$ Disponível em: $<$ http://europa.eu/legislation_summaries/employment_and_social_policy/health_hygiene_ safety_at_work/c11113_pt.htm>. Acesso em: 18 ago. 2012.

${ }^{280}$ OLIVEIRA, Sebastião Geraldo de. Proteção jurídica à saúde do trabalhador. 5. ed. São Paulo: LTr, 2010. p. 97.

${ }^{281}$ Idem, ibidem.
} 
Nadia Demoliner Lacerda ressalta práticas recentes destacadas pela OIT em países como a França, Hungria, Índia e Polônia, de integração entre os diversos atores responsáveis pela prevenção da saúde dos trabalhadores, como forma de contribuir para a implantação de padrões de alta qualidade no gerenciamento de riscos ao meio ambiente de trabalho. $^{282}$

Nos Estados Unidos da América, a mens legis é no sentido de que o trabalhador, pela atividade profissional, não deve sofrer prejuízo algum para sua saúde, nem diminuição da capacidade de trabalho ou expectativa de vida.

Nesse país, como salienta Sebastião Geraldo de Oliveira, a lei determina que o Secretário de Saúde Pública publique anualmente uma lista com todas as substâncias utilizadas ou depositadas nos locais de trabalho consideradas potencialmente tóxicas e divulgue uma vez por ano estudos empreendidos por ampla gama de profissionais, sobre os efeitos patológicos ou eventuais perdas de capacidade para o trabalho, pela exposição crônica a determinadas substâncias. E, ainda, o Instituto Nacional de Segurança e Higiene no Trabalho deverá instituir programas de investigação e experiências para servir de base na elaboração de novas normas ou mesmo para modificar ou aumentar a eficiência das normas antigas. $^{283}$

\subsection{Direito à saúde - conceito de preservação de acordo com a Organização Mundial da Saúde - OMS}

De acordo com a Organização Mundial da Saúde (OMS), o conceito de "saúde" significa um estado completo de bem-estar, físico, mental e social e não consiste apenas na ausência de enfermidade. Esse conceito adotado pela OMS foi divulgado na carta de princípios de 7 de abril de 1948 (desde então o Dia Mundial da Saúde), implicando o reconhecimento do direito à saúde e da obrigação do Estado na promoção e proteção da saúde.

\footnotetext{
${ }^{282}$ LACERDA, Nadia Demoliner. Segurança e saúde do trabalhador: para onde vamos? O debate nacional sobre a concepção preventiva do novo seguro de acidente. São Paulo: LTr, 2011. p. 91.

${ }^{283}$ Lei de 29 de dezembro de 1970, art. 2. ${ }^{\circ}$, b, Série Legislativa, Ginebra, 1970, EE.UU; 1, p. 2.
} 
Este conceito refletia, explica Moacyr Scliar, ${ }^{284}$ de um lado, uma aspiração nascida dos movimentos sociais do pós-guerra: o fím do colonialismo, a ascensão do socialismo. Saúde deveria expressar o direito a uma vida plena, sem privações. Um conceito útil para a análise dos fatores que intervêm sobre a saúde, e sobre os quais a saúde pública deve, por sua vez, intervir, é o de campo da saúde, formulado em 1974 por Marc Lalonde, titular do Ministério da Saúde e do Bem-estar do Canadá - país que aplicava o modelo médico inglês, segundo o qual o campo da saúde abrange: a biologia humana, que compreende a herança genética e os processos biológicos inerentes à vida, incluindo os fatores de envelhecimento; o meio ambiente, que inclui o solo, a água, o ar, a moradia, o local de trabalho; o estilo de vida, do qual resultam decisões que afetam a saúde: fumar ou deixar de fumar, beber ou não, praticar ou não exercícios; a organização da assistência à saúde.

E o conceito de "saúde" adotado por Edith Seligmann Silva, a partir dos ensinamentos de Canguilhem, é um "estado ideal em que as forças vitais predominam na harmonização da variabilidade biopsicossocial - própria dos processos psicoorgânicos humanos, imersos no percurso existencial e na vida social". ${ }^{285}$

\subsubsection{A saúde do trabalhador como direito humano}

Para os fins da Convenção 155 da OIT, que trata da "Segurança e Saúde dos Trabalhadores", como se vê no artigo 3, alínea "e", o termo "saúde", com relação ao trabalho, abrange não só a ausência de afecções ou de doenças, mas também os elementos físicos e mentais que afetam a saúde e estão diretamente relacionados com a segurança e a higiene no trabalho, na linha do conceito de saúde adotado pela Organização Mundial de Saúde.

No direito pátrio, reitere-se, a saúde, o trabalho e a segurança são direitos sociais insertos no artigo $6 .^{\circ}$ da Constituição Federal. O inciso XXII do artigo $7 .^{\circ}$ da Carta estatui

${ }^{284}$ SCLIAR, Moacyr. História do conceito de saúde. Disponível em: <http://www.scielo. br/pdf/physis/v17n1/v17n1a03.pdf >. Acesso em: 18 ago. 2012.

${ }^{285}$ SILVA, Edith Seligmann. Trabalho e desgaste mental: o direito de ser dono de si mesmo. São Paulo: Cortez, 2011. p. 36. 
que é direito dos trabalhadores urbanos e rurais a redução dos riscos inerentes ao trabalho, por meio de normas de saúde, higiene e segurança.

Tais normas, quando do advento da Constituição, já existiam e estão inseridas nos artigos 154 e seguintes da CLT, com redação dada pela Lei 6.514/1977. E ainda, regulamentando essas normas legais, vigoram as Portarias 3.214/1978 e 3.067/1988, emitidas com fulcro no artigo 155, I, da CLT, que aprovaram as Normas Regulamentadoras das ações e serviços em matéria de saúde, higiene e segurança no trabalho urbano e rural - são as NRs e NRRs.

Por tudo o que já foi exposto nos tópicos anteriores, pode-se afirmar que a saúde do trabalhador é um direito humano e como tal inalienável e irrenunciável. E, se a saúde do trabalhador é algo a ele inerente, imanente, como diz José Antônio Ribeiro de Oliveira Silva, trata-se de um direito natural, no sentido de intrínseco à conformação de sua personalidade e de seu desenvolvimento enquanto pessoa.

Esse autor identifica nesse direito um conteúdo essencial, componente do rol de necessidades básicas do ser humano. O direito à saúde do trabalhador tem

[...] um conteúdo essencial bastante extenso, configurando um direito individual subjetivo à sua proteção. Na complementaridade entre os direitos à vida (com suas projeções exteriores - a integridade físicofuncional e moral), à saúde em sentido estrito e ao meio ambiente equilibrado, é que se identifica o conteúdo essencial do direito em questão. Nessa conformação teve papel decisivo a Organização Internacional do Trabalho, adotando convenções e recomendações para a proteção à saúde do trabalhador, muito antes da Aliança das Nações e da Organização das Nações Unidas.

Demais, as normas de proteção à saúde do trabalhador são de ordem pública. De maneira que a saúde do trabalhador, como direito básico, fundamental, tem de ser atendida em quaisquer circunstâncias, em nome do princípio-guia do sistema jurídico brasileiro, qual seja, o da dignidade da pessoa humana, indissociável do próprio direito à vida, o fundamento último de todo Estado de Direito, social ou não [...]. ${ }^{286}$

${ }^{286}$ SILVA, José Antônio Ribeiro de Oliveira. A saúde do trabalhador como um direito humano. Revista do Tribunal Regional do Trabalho da 15. ${ }^{a}$ Região, n. 31, p. 119-120, 2007. 
É direito do ser humano a vida, a ser vivida com qualidade, saúde e dignidade; trata-se de uma aspiração da humanidade de que tal direito seja estendido a todos, e esse direito não pode sofrer solução de continuidade quando o trabalhador adentra ao local de trabalho. 


\section{CAPÍTULO 3 \\ TRABALHO PENOSO}

\subsection{Conceito}

A Constituição Federal de 1988 prevê, no artigo $7 .^{\circ}$, que dispõe sobre os direitos dos trabalhadores urbanos e rurais, no inciso XXIII, "adicional de remuneração para as atividades penosas, insalubres ou perigosas, 'na forma da lei"”.

O trabalho insalubre e o trabalho perigoso já estavam regulamentados por legislação ordinária e infralegal, vigentes antes da promulgação da Constituição da República, e foram recepcionados pela Carta. No entanto, até hoje o adicional para atividades penosas não foi regulamentado, tampouco existe conceituação jurídica de "trabalho penoso".

Antonio Rodrigues de Freitas Jr. tece indagações sobre o que se deve compreender por trabalho penoso, qual o perfil de sua tipicidade e como delimitar sua esfera de cobertura. E em razão dessas interrogações observa que, embora a disposição constitucional seja imediatamente aplicável, reveste-se de eficácia contida, conforme ensinamentos de José Afonso da Silva, isto é, condiciona-se ao advento de disposição que lhe determine o conteúdo. ${ }^{287}$ Prossegue esse autor dizendo que a regulamentação do "trabalho penoso" por meio de lei ordinária contribuiria para a delimitação de seu conteúdo; contudo, a inexistência de definição infraconstitucional não deve obstar a atividade hermenêutica, que não necessita se curvar ante a norma positiva.

E, assim, Freitas passa a designar trabalho penoso como aquele que "se mostre realizado em circunstâncias tais que causem, ao seu agente, desconforto, fadiga, tédio, repugnância ou mal-estar; numa proposital tautologia: pena". 288

\footnotetext{
${ }^{287}$ FREITAS JR., Antonio Rodrigues de. Tópicos da agenda protecionista na nova Constituição brasileira. Revista Jurídica do Trabalho, ano II, n. 5, p. 110-111, abr.-jun. 1989.

${ }^{288}$ Idem, ibidem.
} 
Ressalta que se trata de circunstâncias verificáveis, indiferentemente de se constatar que o trabalhador está exposto a agente comprovadamente agressivo, capaz de provocar-lhe danos à saúde.

Observe-se, aqui, que para traçar o perfil de trabalho penoso e buscar a conceituação dessa figura jurídica é mister ressaltar que não importa o "sentimento" de terceiros a respeito daquele trabalhador que hipoteticamente estiver realizando atividades enquadráveis como penosas. Portanto, não se trata de sentir "pena" do indivíduo; importam as condições em que o trabalho é executado e o que o próprio trabalhador sente, física e mentalmente, em relação àquela determinada atividade que executa. ${ }^{289}$

Da análise da origem etimológica dos termos "pena" e "penoso", constata Freitas o emprego dos vocábulos com sentido que evidencia a existência de uma dimensão relacional entre dois seres humanos: o que sofre com aquele que dele se compadece. Alerta que não é esse o caminho a ser trilhado, na busca de delimitar o conteúdo de um direito:

A reconstrução deliberada da noção de pena, para os efeitos colimados neste trabalho, justifica-se como imperativo de se atribuir ou de se delimitar o conteúdo de um "direito" alusivo à aproximação do homem consigo mesmo, por intermédio do trabalho, e não de um atributo da compaixão ou da piedade humanas. ${ }^{290}$

Marcuse afirma que o "caráter penoso do trabalho" é o mais exposto a interpretações equivocadas. Há um equívoco básico em remetê-lo às determinadas "condições em que o trabalho é executado, à configuração técnico-social do trabalho, à resistência do material etc.; assim, não é idêntico a 'sentimentos de aversão', 'impedimentos', 'manifestações de fadiga' que se instalam com e também antes de determinados trabalhos". O sentido de penoso é que "no trabalho a prioridade é sempre a

${ }^{289}$ De acordo com, Aurélio Buarque de Holanda Ferreira (Novo dicionário Aurélio, 1. ed., 12. impressão, Rio de Janeiro: Nova Fronteira), penoso é um adjetivo que significa "que causa pena ou sofrimento; que incomoda; que produz dor; doloroso; que é difícil, complicado.

E pena, conforme o Novo dicionário Aurélio, origina-se do grego poiné e pelo latim poena; além da acepção jurídica, de castigo, punição imposta pelo Estado e sanção de caráter civil, fiscal ou administrativo, pecuniária ou não, os verbetes elencam sentimentos, como sofrimento, padecimento, aflição, piedade, compaixão, dó, mágoa, desgosto, tristeza.

${ }^{290}$ FREITAS JR., Antonio Rodrigues de. Tópicos da agenda protecionista na nova Constituição brasileira. Revista Jurídica do Trabalho, ano II, n. 5, p. 112, abr.-jun. 1989. 
própria coisa, e não o trabalhador, inclusive quando ainda não ocorreu uma separação total entre trabalho e "produto do trabalho"". No trabalho o homem sempre é remetido a um outro distante de seu ser próprio, ele sempre está com algo outro e para outros”, e, ao trabalhar, o homem "se deixa guiar pela coisa, se subordina à sua normatividade e se vincula a ela, inclusive quando domina seu objeto, recriminando-o, dirigindo-o, abandonando-o". 291

A dificuldade conceitual persiste. Afirma Sebastião Geraldo de Oliveira que a resposta ao questionamento de quais atividades deveriam ser incluídas pelo legislador para fins de pagamento do adicional de trabalho penoso ou de penosidade não é conclusiva, “diante da imprecisão terminológica e abrangência polissêmica do vocábulo "penoso". 292

Prossegue Sebastião Geraldo de Oliveira a respeito da dificuldade de formulação de um conceito que possa ser juridicamente aplicável:

"Cada pessoa tem uma percepção particular de trabalho penoso [...]. Aliás, se adotarmos interpretação literal dos preceitos bíblicos, do antigo testamento, qualquer atividade estará abrangida, diante da condenação imposta pelo Senhor a Adão e seus descendentes: ... a terra será maldita por tua causa; tirarás dela o sustento com trabalhos penosos todos os dias da tua vida. ${ }^{293}$

Para se delimitar o "trabalho penoso", é preciso examinar as condições em que o trabalho é executado. No entanto, não basta a verificação dos fatores ambientais ou da presença de determinado agente agressivo, físico, químico ou biológico; não se busca, aqui, analisar aspectos isolados do posto de trabalho, e sim aspectos multifatoriais, tanto visíveis e materiais como imateriais. Desse modo, cumpre analisar tanto os aspectos objetivos quanto subjetivos presentes, que emanam de uma relação que envolve a organização do trabalho, o tipo de tarefa prescrita; se o trabalho é desenvolvido individualmente ou em equipe; o ambiente de trabalho; os meios materiais e equipamentos existentes; o produto (resultado da produção); o aspecto temporal da tarefa, isto é, o tempo para execução, e até o horário em que o trabalho é executado.

\footnotetext{
${ }^{291}$ MARCUSE, Herbert. Cultura e sociedade. São Paulo: Paz e Terra, 1998. v. 2, p. 29 e 47-48.

${ }^{292}$ OLIVEIRA, Sebastião Geraldo de. Proteção jurídica à saúde do trabalhador. 5. ed. São Paulo: LTr, 2010. p. 175.

${ }^{293}$ Idem, ibidem, p. 175.
} 
Nesse sentido, essa conceituação exige o estudo da natureza do trabalho, é necessário perscrutar as situações-limite oriundas da forma de organização do trabalho, e se tais situações, de fato, não têm possibilidade de controle e amenização; assim, engloba fatores organizacionais do trabalho, como mencionamos em capítulo anterior, bem como características pessoais, físicas e psíquicas do trabalhador.

Diante disso, colocam-se dificuldades conceituais a serem enfrentadas: o que é risco; qual a definição de nocivo; quais as diferenças entre trabalho insalubre e perigoso, para chegarmos à conceituação de "penoso". A distinção entre penosidade e insalubridade e periculosidade, considerando-se a regulamentação legal quanto às duas últimas, será tratada mais adiante.

$\mathrm{Na}$ busca do conceito de "trabalho penoso" e para saber em que situações determinada atividade é de risco, nociva, insalubre, perigosa ou penosa, cumpre de início diferenciar trabalho, tarefa e atividade, que precedem a almejada conceituação.

\subsubsection{Natureza da atividade e seu contexto de execução}

Antes disso, registre-se que, anteriormente à previsão constitucional contida no artigo 7. ${ }^{\circ}$, XXIII, da Carta de 1988, a legislação pátria já havia tratado do "trabalho penoso". A primeira vez que essa previsão surgiu no ordenamento jurídico brasileiro foi na Lei Orgânica da Previdência Social, Lei 3.807, de 26 de agosto de 1960, que dispunha sobre a concessão de aposentadoria especial para o trabalho penoso, embora não cuidasse de sua conceituação. ${ }^{294}$

A regulamentação da Lei 3.807/1960 é efetuada por meio dos Decretos 53.831, de 25 de março de 1964, 63.230, de 10 de setembro de 1968, e do 72.771, de 6 de setembro de 1973, que não trazem o conceito de penosidade, somente são acompanhados de quadros que classificam as atividades, grupos profissionais e agentes nocivos presentes nos ambientes de trabalho, determinando para cada um o tempo de trabalho mínimo $(15,20$ ou

\footnotetext{
294 “Art. 31. A aposentadoria especial será concedida ao segurado que, contando no mínimo 50 (cinquenta) anos de idade e 15 (quinze) anos de contribuições, tenha trabalhado durante 15 (quinze), 20 (vinte) ou 25 (vinte e cinco) anos pelo menos, conforme a atividade profissional, em serviços que, para esse efeito, forem considerados penosos, insalubres ou perigosos, por Decreto do Poder Executivo."
} 
25 anos), para fazer jus à concessão da aposentadoria especial. Observe-se que a Lei 3.807/1960 foi revogada pelo Decreto 62.755/1965.

Leny Sato explicita que os quadros anexos aos Decretos contemplam um número limitado de atividades, grupos profissionais e agentes nocivos, não havendo em qualquer deles exposição das premissas e critérios adotados para enquadramento.

Afirma essa autora que

Apenas o quadro anexo ao decreto de n. 53.831 de 25 de março de 1964 (anexo I) fornece indicações sobre os pressupostos adotados, auxiliando a apreensão da lógica da classificação, pois ao lado de cada grupamento de atividade, setor ou agentes nocivos designa se o trabalho é "penoso", perigoso ou insalubre. Um mesmo grupamento de atividades profissionais pode ser classificado em mais de uma categoria. Dessa forma, é possível entender porque aqueles trabalhadores que desempenham "trabalhos permanentes em instalações ou equipamentos elétricos com risco de acidentes - eletricistas, cabistas, montadores e outros", gozam do direito à aposentadoria especial aos 25 anos de trabalho, pois estão submetidos à condições consideradas perigosas. Raciocínio análogo pode ser feito para aqueles que trabalham com "germes infecciosos ou parasitários - animais - serviços de assistência médica, odontológica e hospitalar e outras atividades afins", os quais gozam do direito à aposentadoria especial ao completarem 25 anos de trabalho, pois sua atividade profissional é considerada insalubre, ou seja, causa doença. [...] ${ }^{295}$

Diga-se que no referido quadro, anexo ao Decreto 53.831/1964, constam as seguintes atividades consideradas penosas:

- Trabalhos permanentes no subsolo em operações de corte, furação, desmonte e carregamento nas frentes de trabalho (observe-se que essas atividades eram classificadas também como insalubres e perigosas);

- Trabalhos permanentes em locais de subsolo afastados das frentes de trabalho, galerias, rampas, poços, depósitos etc. (também classificados como insalubres);

${ }^{295}$ SATO, Leny. Abordagem psicossocial do trabalho penoso: estudo de caso de motoristas de ônibus urbano. 1991. Dissertação (Mestrado) - Pontifícia Universidade Católica de São Paulo, p. 4. 
- Motorneiros e condutores de bondes, motoristas e cobradores de ônibus, motoristas e ajudantes de caminhão;

- Professores.

A esse respeito, sustenta Leny Sato que no Decreto regulamentador não são especificados os agentes ou condições que definam o "trabalho penoso". Esse é o caso dos motoristas e cobradores de ônibus, dos professores, bem como ilustra, da atividade profissional de telefonista, que à época em que tal estudo foi realizado fora considerada penosa para fins de concessão de aposentadoria especial, na forma da Lei 7.850, de 23 de outubro de 1989. Essa lei foi posteriormente revogada pela Lei 9.528, de 10 de dezembro de 1997, que alterou dispositivos das Leis 8.212 e 8.213, ambas de 24 de julho de 1991 .

Atualmente, a Lei 8.112, de 11 de dezembro de 1990, que dispõe sobre o regime jurídico dos servidores públicos civis da União, das autarquias e das fundações públicas federais, assim prevê o adicional de atividade penosa:

Art. 71. O adicional de atividade penosa será devido aos servidores em exercício em zonas de fronteira ou em localidades cujas condições de vida o justifiquem, nos termos, condições e limites fixados em regulamento.

Observe-se que a procura pela conceituação de trabalho penoso tornou-se mais intensa após a promulgação da Constituição Federal de 1988, tendo em vista a previsão do adicional de remuneração das atividades penosas.

Christiani Marques resgata o histórico dessa previsão constitucional. Relata que por ocasião da instalação da Assembleia Constituinte, em 1987, o relator da comissão de sistematização, Deputado Bernardo Cabral, entendeu que a supressão do termo "penoso" prejudicaria o trabalhador e deixaria de identificar e contemplar as atividades desgastantes. Nas votações finais, o adicional para atividades penosas não foi contemplado. Diante disso, o Deputado Nelson Aguiar foi ao Plenário da Câmara dos Deputados, destacou a solicitação da Secretária Estadual do Menor em São Paulo, Alda Marcoantonio, de que era necessário combater o trabalho infantil, diante da exposição a trabalhos perigosos e penosos. Assim, o termo "penoso" foi promulgado no artigo $7 .^{\circ}$, inciso XXIII, da 
Constituição Federal; contudo, não há nos Anais da Assembleia Constituinte nenhum estudo jurídico sobre a conceituação e caracterização da penosidade. ${ }^{296}$

Procuremos então analisar a atividade, sua natureza, para depois passarmos à definição de nocividade e depois estudarmos os critérios que caracterizam a penosidade.

Vejamos os aspectos que envolvem o trabalho, a tarefa e a atividade, na busca de uma melhor definição. Dissemos em capítulo anterior que diversas ciências têm por objeto de estudo o trabalho; não cabe alongar mais a esse respeito. Uma correta abordagem não deve privilegiar unilateralmente os aspectos econômicos, sociológicos ou biológicos, deve abordar o trabalho com um enfoque global.

Ressalte-se que a ergonomia também tem por objeto o trabalho. Aqui lembramos que "trabalho" pode significar "condições de trabalho" (trabalho penoso, trabalho pesado, trabalho cansativo); "resultado do trabalho" (trabalho malfeito) ou a própria "atividade de trabalho" (fazer seu trabalho, estar sobrecarregado de trabalho).

Como ensina Guérin, a atividade, as condições e o resultado do trabalho não existem independentemente uns dos outros. Assim, o trabalho é a unidade dessas três realidades. ${ }^{297} \mathrm{~A}$ análise do trabalho é uma análise desse sistema e do seu funcionamento.

O ideal, para a sua correta apreensão, seria não separar as diferentes realidades que o compõem. De fato, até em função da amplitude teórica e prática a ser investigada, as realidades que compõem o trabalho são consideradas separadamente. Assim, os diversos departamentos de uma empresa preocupam-se e fixam o foco em conformidade com seus objetivos específicos: o departamento de recursos humanos preocupa-se principalmente com os trabalhadores em atividade; o departamento comercial analisa os resultados obtidos, observando a relação qualidade/preço; o serviço de segurança do trabalho

\footnotetext{
${ }^{296}$ MARQUES, Christiani. A proteção ao trabalho penoso. São Paulo: LTr, 2007. p. 60-61.

${ }^{297}$ GUÉRIN, F. et al. Compreender o trabalho para transformá-lo: a prática da ergonomia. São Paulo: Blucher: Fundação Vanzolini, 2001. p. 11-13.
} 
investiga as razões do aumento do número de acidentes e mobiliza-se em torno das condições organizacionais da produção. ${ }^{298}$

A atividade, para a empresa, corresponde aos resultados obtidos e os objetivos a que se propôs. O enfoque varia, assim, de acordo com o interlocutor, mas quase sempre os meios materiais e financeiros são lembrados. Quando os operadores falam espontaneamente de seu trabalho, tratam dos resultados e depois descrevem os meios que utilizam.

A maneira espontânea de falar do trabalho da empresa e na empresa revela o que é uma tarefa: é um resultado antecipado, fixado dentro de condições determinadas. Guérin et al. observam que as pessoas não falam de seu trabalho, mas de sua tarefa, e traçam a seguinte distinção:

A tarefa mantém, evidentemente, uma relação estreita com o trabalho através das condições e dos resultados deste. Mas essa relação é a do objetivo à realidade: as condições determinadas não são as condições reais, e o resultado antecipado não é o resultado efetivo. Essa é uma primeira razão pela qual a tarefa não deve ser confundida com o trabalho.

Mas existe uma segunda razão mais fundamental: fica faltando a atividade de trabalho, ou seja, a maneira como os resultados são obtidos e os meios utilizados. [...]. ${ }^{299}$

Esses autores salientam que convém distinguir três realidades:

- a tarefa como resultado antecipado fixado em condições determinadas;

- a atividade de trabalho como realização de tarefa;

- o trabalho como unidade da atividade de trabalho, das condições reais e dos resultados efetivos dessa atividade. ${ }^{300}$

\footnotetext{
${ }^{298}$ GUÉRIN, F. et al. Compreender o trabalho para transformá-lo: a prática da ergonomia. São Paulo: Blucher: Fundação Vanzolini, 2001. p. 11-13.

${ }^{299}$ Idem, ibidem, p. 14.

${ }^{300}$ Idem, p. 15.
} 
Distinguem que a tarefa não é o trabalho, mas o que é prescrito pela empresa ao trabalhador; a prescrição é imposta, é exterior, determina e constrange a atividade concreta. A atividade de trabalho é uma estratégia de adaptação à situação real de trabalho, objeto da prescrição. E a distância entre o prescrito e o real é a manifestação concreta da contradição presente no ato de trabalho. ${ }^{301}$

E o trabalho congrega como unidade a atividade de trabalho, as condições reais e os resultados efetivos dessa atividade. ${ }^{302}$

Guérin e os demais autores ensinam que a atividade de trabalho é uma forma da atividade humana; a atividade se opõe à inércia; o trabalho tem objetivo socialmente determinado. Prosseguem dizendo que sem atividade humana não há trabalho, ainda que possa haver produção, por meio de determinado automatismo.

Observam que a atividade de trabalho distingue-se da atividade humana em geral; como exemplo, mencione-se que as mulheres sem atividade remunerada são consideradas "sem profissão"; o estudante, a dona de casa, o aposentado, são consideradas pessoas que "não trabalham", porque desempenham atividades sem remuneração. Donde se conclui que não é a atividade em si, mas sua finalidade, que caracteriza o trabalho. ${ }^{303}$

\footnotetext{
${ }^{301}$ A ergonomia mostra que a noção de trabalho prescrito tem sua origem na administração científica do trabalho (Taylor, 1987), que busca estabelecer a maneira como o trabalho deve ser executado (modo de utilizar as ferramentas e equipamentos), o tempo previsto para as operações, os modos operatórios e as regras por respeitar (Laville, Teiger e Daniellou, 1989). A noção de trabalho prescrito comporta duas dimensões complementares: (1) trabalho teórico lato sensu, constituído pelas representações sociais, habitando os pontos de vista dos diferentes sujeitos na esfera da produção (do operário ao diretorpresidente); e (2) tarefas previstas, circunscritas num contexto sociotécnico particular, evidenciando os braços invisíveis da organização do trabalho que fixa as regras da produção. [...] Por sua vez, a noção de trabalho real é construída em termos da atividade dos operadores e ocupa um lugar hierárquico central no estudo do trabalho. A atividade sintetiza e integra os diferentes fatores que estruturam o processo de trabalho (Guérin et al., 1997). É na situação real de trabalho que a atividade dá visibilidade aos determinantes que condicionam a sua interação com o meio (FERREIRA, Mário César; FREIRE, Odaleia Novais. Carga de trabalho e rotatividade na função de frentista. Disponível em: $<$ http://www.scielo.br/pdf/rac/v5n2/v5n2a09.pdf>. Acesso em: 9 nov. 2012).

${ }^{302}$ Idem, ibidem.

303 GUÉRIN, F. et al. Compreender o trabalho para transformá-lo: a prática da ergonomia. São Paulo: Blucher: Fundação Vanzolini, 2001. p. 16.
} 
O trabalho é exterior ao homem, isto é, o homem não tem domínio sobre as condições, tampouco sobre os resultados da atividade profissional; por isso é atividade imposta, sendo o regime assalariado forma dessa imposição.

Além disso, poucos desenvolvem a atividade profissional que gostariam; e mesmo essa minoria não tem controle sobre as condições de exercício de seu ofício: a organização do trabalho já está mais ou menos definida, o tempo de realização das tarefas geralmente é imposto e os critérios de qualidade do resultado são socialmente definidos. Conclui-se daí que o trabalho apresenta sempre um caráter duplo, pessoal e socioeconômico, a depender do ângulo em que é abordado. ${ }^{304}$

No tocante a essa dimensão pessoal, observe-se que o resultado da atividade de um trabalhador é sempre singular: mesmo na produção em massa, os objetos padronizados têm trabalho humano investido e trazem o traço pessoal, ainda que ínfimo. Assim, no que diz respeito às condições de trabalho, são também condições da atividade pessoal. Note-se que os trabalhadores arrumam seu local de trabalho não somente no aspecto da decoração, personalizando o espaço, colocando fotos da família etc., como também organizam em função do trabalho que será executado, com disposição dos objetos e equipamentos necessários para a melhor execução.

E, por óbvio, o trabalho tem caráter socioeconômico e a análise do trabalho não pode desprezar esta dimensão, dado que é ela que transforma a atividade humana em atividade de trabalho.

Como examinamos em capítulo anterior, o processo de produção sofreu profundas transformações ao longo dos anos, até os dias atuais, de economia globalizada e utilização de avançada tecnologia, que vêm determinando considerável transformação do trabalho. Guérin registra que tais mudanças afetam o conteúdo da atividade efetiva e o quadro dessa atividade, destacando as palavras empregadas no cotidiano que demonstram essas transformações:

\footnotetext{
${ }^{304}$ GUÉRIN, F. et al. Compreender o trabalho para transformá-lo: a prática da ergonomia. São Paulo:
} Blucher: Fundação Vanzolini, 2001. p. 16-17. 
[...] controle, vigilância, informação, comunicação, flexibilidade, reatividade, mobilidade, iniciativa, motivação, responsabilidade, inteligência, etc. Não ignorando o caráter ideológico que podem ter em certas circunstâncias, indicam a existência de novas exigências e constrangimentos que não eram levados em conta pela abordagem taylorista. $^{305}$

Contudo, destacam Guérin e os demais autores que empresas de um mesmo ramo de atividade não evoluem no mesmo ritmo; existem desigualdades de desenvolvimento tecnológico. Ilustram como tais desigualdades podem afetar um mesmo processo de produção, exemplificando com o da confecção, em que o setor de corte sofreu evoluções mais profundas que as operações de costura e montagem; assim, é comum encontrar em um processo sofisticado o trabalho de operárias sem qualificação, no sentido mais taylorista do termo. Existem casos em que apenas a nomenclatura da função mudou, o conteúdo é mantido idêntico. Salientam tais autores que se reivindica cada vez menos o taylorismo nas empresas, como demonstram pesquisas no domínio da organização do trabalho; no entanto, na prática, a evolução da atividade dos trabalhadores continua a entrar frequentemente em conflito com a aplicação dos princípios tayloristas de organização do trabalho. $^{306}$

Observe-se que as questões relativas ao trabalho costumam ser enquadradas em um modelo que impede um tratamento eficaz. De acordo com o enfoque da análise ergonômica, no domínio do trabalho as demandas são formuladas sob um sistema determinista e devem ser reconstruídas de acordo com as características dos sistemas vivos; caso contrário, os problemas concretos ficam ocultos e as possibilidades de ação são limitadas.

Ada Ávila Assunção e Francisco de Paula Antunes Lima lembram que são complexos os fenômenos que envolvem as dimensões humanas implicadas no trabalho, e, na busca de abrangê-los, a concepção de saúde atual ultrapassa a concepção de ausência de

\footnotetext{
${ }^{305}$ GUÉRIN, F. et al. Compreender o trabalho para transformá-lo: a prática da ergonomia. São Paulo: Blucher: Fundação Vanzolini, 2001. p. 30.

${ }^{306}$ Idem, ibidem, p. 31.
} 
doenças, expandindo-se para os aspectos econômicos e sociais. ${ }^{307}$ No entanto, destacam esses autores, a abordagem dos fenômenos de saúde relacionados ao trabalho continua lastreada sobre a ideia de uma passividade dos trabalhadores, diante das condições inseguras ou dos fatores de risco. Dizem que a nocividade está presente quando a organização do trabalho diminui as possibilidades do trabalhador de evitar a exposição ao fator de risco, por exemplo, ao impor um quadro temporal rígido para a realização das tarefas.

Cabe aqui questionar o que é risco. Trata-se de um conceito polissêmico, oriundo de várias áreas do saber, que permite diferentes abordagens. Do ponto de vista da saúde do trabalhador risco é um conceito que se refere à possibilidade/probabilidade de ocorrência de eventos que tenham consequências negativas à saúde, ou seja, que possam causar algum tipo de agravo ou dano à saúde de um indivíduo, de um grupo populacional ou ao ambiente. $^{308}$

Os riscos no ambiente laboral podem ser classificados em cinco tipos, de acordo com a Portaria 3.214/1978, do Ministério do Trabalho e Emprego (MTE): 1. Riscos de acidentes: qualquer fator que coloque o trabalhador em situação vulnerável e possa afetar sua integridade, e seu bem-estar físico e psíquico. São exemplos de risco de acidente: as máquinas e equipamentos sem proteção, probabilidade de incêndio e explosão, arranjo físico inadequado, armazenamento inadequado, etc.; 2. Riscos ergonômicos: qualquer fator que possa interferir nas características psicofisiológicas do trabalhador, causando desconforto ou afetando sua saúde. São exemplos de risco ergonômico: o levantamento de peso, ritmo excessivo de trabalho, monotonia, repetitividade, postura inadequada de trabalho etc.; 3. Riscos físicos: consideram-se agentes de risco físico as diversas formas de energia a que possam estar expostos os trabalhadores, tais como: ruído, calor, frio, pressão, umidade, radiações ionizantes e não ionizantes, vibração etc.; 4. Riscos químicos: consideram-se agentes de risco químico as substâncias, compostos ou produtos que possam

\footnotetext{
${ }^{307}$ ASSUNÇÃO, Ada Ávila; LIMA, Francisco de Paula Antunes. A contribuição da ergonomia para a identificação, redução e eliminação da nocividade do trabalho. In: MENDES, René (Org.). Patologia do trabalho. São Paulo: Atheneu, 2005. p. 1768.

${ }^{308}$ DE SETA, Marismary Horsth; REIS, Lenice G. da Costa. As vigilâncias do campo da saúde, o risco como conceito fundamental e a caracterização dos seus processos de trabalho. Qualificação de Gestores do SUS. Disponível em: <http://www.medtrab.ufpr.br/arquivosparadownload/Politicaspublicaem SaudeeTrabalho/7vigilancisrisco.pdf>. Acesso em: 4 nov. 2012.
} 
penetrar no organismo do trabalhador pela via respiratória, nas formas de poeiras, fumos, gases, neblinas, névoas ou vapores, ou que sejam, pela natureza da atividade, de exposição, possam ter contato ou ser absorvido pelo organismo através da pele ou por ingestão; 5 . Riscos biológicos: são agentes de risco biológico as bactérias, vírus, fungos, parasitas, entre outros. ${ }^{309}$

A tendência atual é a que visa eliminar os riscos para a saúde do trabalhador na sua origem, em vez de se procurar neutralizá-los com a utilização de equipamentos de proteção individual (EPIs), como lembra Sebastião Geraldo de Oliveira; esse autor tece crítica à utilização de EPIs, destacando que está comprovada a resistência do trabalhador quanto ao seu uso, pelo incômodo que causa; além disso, limitam a percepção do ambiente de trabalho, chegando em algumas situações a causar acidentes. Ilustra esse autor que a Diretiva 89/391 consagra como princípio geral de prevenção o combate dos riscos na origem. $^{310}$

O trabalho caracteriza-se como nocivo, segundo Assunção e Lima, quando

[...] as margens postas pela organização do trabalho constrangem o trabalhador e reduzem suas possibilidades de construção da saúde.

Esta construção depende das possibilidades que homens e mulheres, no cotidiano, têm para evitar os riscos, atenuá-los ou eliminá-los durante a realização das suas tarefas, e ainda depende das possibilidades que o trabalhador terá para desenvolver as suas competências que sustentam as estratégias de regulação dos riscos. ${ }^{311}$

Assim, a forma de organização do trabalho, o exame das tarefas prescritas, os meios materiais disponíveis para realizá-las e o aspecto temporal para essa realização são

${ }^{309}$ Disponível em: <http://www.fiocruz.br/biosseguranca/Bis/lab_virtual/tipos_de_riscos.html $>$. Acesso em: 4 nov. 2012.

310 "Directiva del Consejo n. 89/391/CEE", 12 jun. 1989, art. 12. Documentos de Derecho Social, Ginebra, 1990, n. 1, p. 36. Na Itália o Decreto Legislativo 626, de 19 de setembro de 1994, adaptou a diretiva internamente com a seguinte redação: "Articolo 3. Misure generali de tutela. 1. Le misure generali per la protezione della salute e per la sicurezza dei lavoratori sono: a) valutazione dei rischi per la salute e la sicurezza; b) eliminazione dei rischi in relazione alle conoscenze acquisite in base al progresso tecnico e, ove ciò non è possibile, loro riduzione al mínimo". Conf. OLIVEIRA, Sebastião Geraldo de. Proteção jurídica à saúde do trabalhador. São Paulo: LTr, 2010. p. 99-100.

${ }^{311}$ ASSUNÇÃO, Ada Ávila; LIMA, Francisco de Paula Antunes. A contribuição da ergonomia para a identificação, redução e eliminação da nocividade do trabalho. In: MENDES, René (Org.). Patologia do trabalho. São Paulo: Atheneu, 2005. p. 1769. 
fatores primordiais para se estabelecer se o meio ambiente de trabalho é sadio ou se é nocivo à saúde do trabalhador, como passaremos a ver.

\subsubsection{Organização do trabalho: meios materiais, aspectos ambientais, forma de produção e remuneração}

Os trabalhadores que sofrem as más condições de trabalho são considerados os responsáveis pelas insuficiências da produção, sustenta Alain Wisner. Salienta esse autor que tal situação deveria proporcionar a esses trabalhadores uma posição na observação e na melhoria das condições no ambiente de trabalho. No entanto, em virtude de divisão do trabalho, tais trabalhadores não são "aqueles que sabem", e são outros que dizem o que deve ser feito, como os médicos, psicólogos, engenheiros de segurança e ergonomistas. Ressalta Wisner como ainda hoje os trabalhadores não são solicitados a contribuir para as melhorias das próprias condições de trabalho. ${ }^{312}$

A maioria dos estudos a partir dos quais as normas de regulamentação são geradas lastreia-se no trabalho prescrito ou sobre a análise crua dos riscos, e negligencia a variabilidade industrial ou dos serviços prestados, o que é determinante da ação dos trabalhadores, afirmam Assunção e Lima. Explicam que trabalho prescrito é o previsto em normas operacionais formalizadas em procedimentos; diferencia-se das atividades realmente desenvolvidas pelos trabalhadores, o chamado trabalho real. ${ }^{313} \mathrm{Da}$ mesma forma, tecem críticas às pesquisas sobre os problemas de saúde relacionadas ao trabalho, que são limitadas por não levarem em conta a dinamicidade do trabalho e a complexidade psicofisiológica do ser humano.

Lembram que classicamente a saúde ocupacional trata da insalubridade (aspectos relacionados à higiene ocupacional) e da periculosidade (acidentes do trabalho), procurando identificar riscos de diversas naturezas, que estejam efetiva ou potencialmente presentes nas situações de trabalho.

\footnotetext{
${ }^{312}$ WISNER, Alain. Por dentro do trabalho: ergonomia: método \& técnica. São Paulo: FTD: Oboré, 1987. p. 36.

${ }^{313}$ ASSUNÇÃO, Ada Ávila; LIMA, Francisco de Paula Antunes. A contribuição da ergonomia para a identificação, redução e eliminação da nocividade do trabalho. In: MENDES, René (Org.). Patologia do trabalho. São Paulo: Atheneu, 2005. p. 1768.
} 
Explicam esses autores que, mais recentemente, a preocupação com os aspectos ergonômicos levou à necessidade de se estabelecer um novo termo - penosidade - e que esta diferenciação traz uma nova luz sobre os problemas de saúde ocupacional. Explicitam que um trabalho pode ser penoso sem que chegue a ser considerado como perigoso ou insalubre. De outro lado, um trabalho insalubre ou perigoso, assim considerado por um observador externo, pode não ser penoso para aquele que o realiza.

Prosseguem dizendo que os critérios acerca da penosidade introduzidos pela ergonomia tendem a ser mais precisos do que os anteriores, pois

[...] se referem às condições de conforto e - isto é essencial - da perspectiva do trabalhador. Um ruído, por exemplo, pode estar abaixo do nível considerado insalubre $(85 \mathrm{~dB})$, mas pode causar irritação se perturba um trabalho que requer atenção. Da mesma forma, substâncias químicas, vapores ou gases podem não ser tóxicos segundo critérios estritamente científicos, mas geram ansiedade quando sua composição química é desconhecida. Por outro lado, um ambiente com excesso de ruído ou de calor pode ser tolerado, dependendo de como os trabalhadores regulam, individual e coletivamente, a exposição ao risco. O essencial nesta concepção de penosidade é o caráter relacional da exposição, que não mais se esgota na relação unívoca entre o trabalhador (em verdade, apenas o seu corpo é considerado em uma abordagem tradicional) e os ruídos do ambiente, sejam eles físicos ou resultantes de determinações sociais (grifos nossos). ${ }^{314}$

Estabelecem liame entre nocivo e penoso, dizendo que a nocividade, enquanto penosidade,

[...] está relacionada à obrigação rígida para se realizar uma tarefa ou, de modo geral, a acontecimentos vividos como um desconforto na atividade ou como entrave à liberdade de ação, tendo efeitos fisiológicos, cognitivos, afetivos ou sociais para o trabalhador. ${ }^{315}$

Saliente-se que a nocividade das condições de trabalho advém de uma gama de fatores, e tem origem multifatorial. Como diz Antonio Rodrigues de Freitas Jr.,

[...] deriva da circunstância de ser prestado em meio à reunião de um conjunto de fatores adversos, capazes de constituir aspectos relevantes e

\footnotetext{
${ }^{314}$ ASSUNÇÃO, Ada Ávila; LIMA, Francisco de Paula Antunes. A contribuição da ergonomia para a identificação, redução e eliminação da nocividade do trabalho. In: MENDES, René (Org.). Patologia do trabalho. São Paulo: Atheneu, 2005. p. 1768-1769.

${ }^{315}$ Idem, ibidem, p. 1768-1769.
} 
mesmo decisivos na etiologia de inúmeras doenças e deficiências, cujo nexo de causalidade, por outro lado, ainda permanece subestimado quando não ignorado na literatura médica. ${ }^{316}$

Ressalte-se que a nocividade é um dos fatores da penosidade, muito embora não baste para definir a última; e, assim como a nocividade, a penosidade pode ser configurada por um vasto rol de adversidades.

Leny Sato, ao pesquisar as contribuições da doutrina em Saúde do Trabalhador a respeito da matéria, também detectou a inexistência de um conceito claro sobre "trabalho penoso". Afirma que há adjetivação das condições de trabalho como "penosas", mediante basicamente quatro abordagens distintas:

A primeira relaciona as condições "penosas" de trabalho à determinações macrossociais; a segunda associa o "trabalho penoso" a esforços físicos; a terceira abordagem o relaciona a sofrimento mental e a última a esforço e exigências físicas e psíquicas $^{317}$ (grifos nossos).

Cita como exemplo da abordagem macrossocial estudo da Organização Internacional do Trabalho (OIT) de 1986, que relaciona a penosidade do trabalho às consequências geradas pelo desemprego. A esse respeito, há estudo sobre a situação do emprego da mulher, a experiência dos países do Mercosul nas duas últimas décadas do século 20, bem como análise específica dos impactos dos planos econômicos na qualidade do emprego no Brasil. ${ }^{318}$

${ }^{316}$ FREITAS JR., Antonio Rodrigues de. Tópicos da agenda protecionista na nova Constituição brasileira. Revista Jurídica do Trabalho, ano II, n. 5, p. 114, abr.-jun. 1989.

317 SATO, Leny. Abordagem psicossocial do trabalho penoso: estudo de caso de motoristas de ônibus urbano. 1991. Dissertação (Mestrado) - Pontifícia Universidade Católica de São Paulo, p. 7.

${ }^{318}$ BRUSCHINI, Cristina; LOMBARDI, María Rosa. Brasil: La calidad del empleo de las mujeres.Continuidades y cambios. "Más y Mejores Empleos para las Mujeres? La experiência de los países del Mercosul y Chile.

"En el período focalizado, el país ha pasado por agudas transformaciones de orden político, económico y social. El ambiente económico fue particularmente perturbado entre 1986 y 1994, periodo en que el país ha convivido con nada menos que seis planes de estabilización económica: Cruzado I, Cruzado II, Bresser, Verano, Brasil Nuevo y Real. Todos esos planes, cuyo objetivo principal era estancar la crisis inflacionaria, promovieron una sucesión de congelamiento de precios, seguidos de difíciles procesos de desindexación, provocando cinco cambios en la moneda nacional que de Cruzeiro ha pasado, sucesivamente, a Cruzado, Cruzado Nuevo, Cruzeiro Nuevo y, finalmente, Real. 
A ligação entre desemprego, adoecimento e a questão de gênero é analisada por Margarida Barreto:

\section{Suportar a doença para evitar a “dor" do desemprego}

As análises dos dados revelaram motivos diferenciados para a demissão, seguindo uma lógica sexualizada: as mulheres são mais desvalorizadas e culpabilizadas que os homens no espaço fabril. A demissão é vista como um meio de evitar os prejuízos que "sua" doença ou suas idas a médicos causam à produção. Antes, são transferidas constantemente de posto de

La actividad económica osciló entre periodos de crecimiento y recesión, aunque la tónica, principalmente en los años 80 , haya sido de una permanente y prolongada crisis económica. El inicio de la década de los ochenta está caracterizado por la interrupción de un largo periodo de crecimiento de la economía brasileña, con la caída del Producto Interno Bruto y la retracción de la industria manufacturera, principalmente de bienes de consumo durables y bienes intermedios. Habiendo basado su crecimiento en el endeudamiento externo, el país venía sufriendo los efectos de los programas de estabilización económica, implementados por los países industrializados desde la crisis del petróleo en la segunda mitad de la década de los 70. Desequilibrios en la balanza de pagos llevaron al gobierno, en los primeros años de los 80, a negociar con el Fondo Monetario Internacional, a pesar de las intensas resistencias políticas. Las medidas económicas decretadas más adelante han tenido profundo impacto recesivo, provocando la declinación del producto nacional bruto (Cacciamali, citado en Bruschini, 1989).

La intensidad de la recesión económica de los primeros años de la década de los 80 cambia el cuadro de crecimiento anterior, provocando aumentos en las tasas de desempleo y alteración en la distribución de la población económicamente activa, que se desplaza del sector industrial hacia ocupaciones en el sector informal, y se refleja en el aumento de los trabajadores por cuenta propia y en el subempleo. [...] En julio de 1994, se inicia la implantación del Plan Real, proyecto de Fernando Henrique Cardoso, actual Presidente del país, en aquella época Ministro de Hacienda, cuyo objetivo central era la caída de la inflación y la estabilidad de la moneda. [...]

Los análisis referidos al primer año del Plan Real muestran que la rápida apertura de la economía hacia el exterior, combinada con una tasa de cambio sobrevalorizada, generó desequilibrio en las cuentas externas y bajo nivel de crecimiento del producto industrial. Los puestos de trabajo perdidos en la industria han sido sustituidos por otros en los sectores de comercio y de servicios, en gran parte informales, con productividad relativamente más baja y pagando sueldos menores que los de la industria. La tendencia ha sido de reducción de la calidad de los puestos de trabajo generados, que pueden también dejar de crecer, ampliando las tasas de desempleo en los próximos años (Camargo, 1996). Es importante resaltar que, desde el inicio de los años 90, los sectores que generaban buenos empleos habían disminuido su capacidad de crearlos, tendencia que se agudizó con el Plan Real. Se destaca, en ese proceso, la industria que se reestructura para hacer frente a la competencia internacional; el sector financiero, alcanzado por la creciente automatización/informatización, por el subito corte de sus operaciones especulativas en el contexto inflacionario anterior al Plan Real y por un creciente número de fusiones y adquisiciones; las empresas estatales que, a medida que se van privatizando, son obligadas a deshacerse de proporciones significativas de su personal; y la administración pública, cuya reorganización comienza a traducirse en una diminución del número de empleados públicos. Con esto, las posibilidades de conseguir un empleo formal se redujeron en casi 10 puntos porcentuales en las principales regiones metropolitanas. Hasta aquí, la principal contrapartida de este proceso no fue una explosión de la tasa de desempleo, a pesar de que aumentó, sino una creciente precarización de las relaciones de trabajo y, principalmente, un aumento del trabajo por cuenta propia (Conjuntura, 1996). Pochmann (1996) nos recuerda que, mientras el PIB creció alrededor de un $15 \%$ entre 1993 y 1995, el empleo formal registró aumento de sólo un 2\%." Disponível em: <http://www.oitchile.cl/pdf/publicaciones/igu/igu021.pdf $>$. Acesso em: 1. ${ }^{\circ}$ jul. 2011. 
trabalho e de setor, enfrentando novas atividades e dificuldades, tendo que aprender no novo tempo exigido [...]. ${ }^{319}$

Ao tratar da segunda abordagem, que associa o "trabalho penoso" a esforços físicos, Leny Sato ressalta que a grande quantidade de contribuições em pesquisas sobre a matéria concentra-se na área da Fisiologia do Trabalho e da Ergonomia. Explica que para esses estudos a penosidade está associada, em sua grande parte, às atividades profissionais que exijam esforço físico, tendo como técnicas de avaliação as medidas de frequência cardíaca, consumo de oxigênio, gasto de energia, gasto calórico associadas à fadiga física.

De forma didática, Leny Sato relaciona os trabalhos realizados em condições penosas:

- esforço físico intenso no levantamento, transporte, movimentação, carga e descarga de objetos, materiais, produtos e peças;

- posturas incômodas, viciosas e fatigantes;

- esforços repetitivos;

- alternância de horários de sono e vigília ou de alimentação;

- utilização de equipamentos de proteção individual que impeçam o pleno exercício de funções fisiológicas, como tato, audição, respiração, visão, atenção, que leve à sobrecarga física e mental;

- excessiva atenção ou concentração;

- contato com o público que acarrete desgaste psíquico;

- atendimento direto de pessoas em atividades de primeiro socorros, tratamento e reabilitação que acarretem desgaste psíquico e físico;

- trabalho direto com pessoas em atividades de atenção, desenvolvimento e educação que acarretem desgaste psíquico e físico;

- confinamento ou isolamento;

- contato direto com substâncias, objetos ou situações repugnantes e cadáveres humanos e animais;

- trabalho direto na captura e sacrifício de animais. ${ }^{320}$

Edith Seligmann Silva diz que a ciência da ergonomia passou por transformações notáveis, especialmente nos países onde as correlações de força entre empregadores e empregados favoreceram a efetiva participação desses últimos; nesse sentido, passou-se a

\footnotetext{
${ }^{319}$ BARRETO, Margarida Maria Silveira. Violência, saúde e trabalho: uma jornada de humilhações. São Paulo: Educ, 2006. p. 159.

${ }^{320}$ SATO, Leny. Conceito de trabalho penoso. Revista CIPA, São Paulo, v. 15, n. 179, p. 41, 1994.
} 
ter como objeto de estudo o trabalhador em atividade no contexto de uma situação de trabalho; trata-se da chamada ergonomia situada.

E, nessa linha, um dos primeiros aspectos a ser analisado no processo de organização de trabalho é a carga de trabalho, que segundo essa autora representa o conjunto de esforços desenvolvidos para atender às exigências das tarefas. Afirma Seligmann Silva que esse conceito abrange os esforços físicos e os mentais, que por sua vez compreendem os cognitivos e os psicoafetivos (mobilização de sentimentos, controle emocional); estes últimos constituem a carga psíquica.

Estudos realizados por Herval Pina Ribeiro e Francisco Lacaz, por meio do Departamento Intersindical de Estudos e Pesquisas de Saúde e dos Ambientes de Trabalho (Diesat), enfocam o esforço físico excessivo como fator nocivo para a saúde e seu caráter crônico, e as dificuldades de estabelecimento de nexo causal entre os agentes físicos e as doenças:

A ação nociva sobre a saúde, causada pelo esforço físico excessivo, ainda que possa ser aguda, em geral tem caráter crônico. Esta é também uma característica da ação dos agentes físicos (ruído, temperatura, vibração, radiação e pressão).

Este fato - a predominância dos efeitos tardios e nocivos desses agentes sobre a saúde - impede ou dificulta que os trabalhadores estabeleçam uma relação de causa e efeito, entre eles e as doenças ou deficiências orgânicas que acabam por vitimá-los, muitas delas atribuídas à idade e a fatores individuais ou hereditários. Esses fatores, acrescidos das exigência de horas extras, concorrem para aumentar o número de acidentes e doenças do trabalho e consequentemente favorecem o ausentismo. $^{321}$

Observam Pina e Lacaz que, apesar da crescente automatização das máquinas, persiste o esforço físico em diferentes atividades de trabalho; esse esforço, dentro de certos limites, leva a uma fadiga que pode ser recuperada com o repouso. No entanto, se esses limites forem ultrapassados com frequência, restará sempre um desgaste residual que conduzirá à fadiga crônica. Além disso, determinadas condições de trabalho, somadas ao esforço excessivo, como posturas incorretas, condicionadas, por exemplo, pela distância

${ }^{321}$ RIBEIRO, Herval Pina; LACAZ, Francisco A. de Castro. Agentes físicos e doenças. São Paulo: Departamento Intersindical de Estudos e Pesquisas de Saúde e dos Ambientes de Trabalho - DIESAT, 1984. p. 47. 
inadequada entre a máquina e o operador, facilitam o surgimento da fadiga. Esta também pode ser precipitada pelo tipo de solicitação muscular, em especial no trabalho estático, com musculatura contraída por muito tempo, sem relaxar, como ocorre quando o trabalhador segura ou carrega peso com os braços distendidos. São fatores coadjuvantes a fome ou a sensação de fraqueza, provocadas pela insuficiência alimentar, o que lamentavelmente não é raro ocorrer nas camadas mais pobres da população. ${ }^{322}$ Levantamento realizado à época entre trabalhadores da indústria automobilística constatou que cerca de $30 \%$ deles trabalhavam até a hora do almoço praticamente em jejum.

Acrescente-se aqui, no que respeita às posturas incorretas ou condições ergonomicamente inadequadas: determinadas tarefas são realizadas em pé, durante toda a jornada, não sendo permitido ao trabalhador sentar-se; outras profissões exigem que o obreiro permaneça em posição inadequada e de risco, por exemplo, equilibrando-se na traseira de um caminhão e realizando suas tarefas correndo, como são desempenhadas as atividades do coletor de lixo, que serão examinadas adiante.

Antonio Rodrigues de Freitas Jr. denomina a fadiga motora de objetiva e a mental, de subjetiva; destaca esse autor que o trabalho realizado em condições fatigantes, qualquer que seja a natureza da fadiga, é fator nocivo ao organismo humano. Distingue, aqui, quanto à fadiga, afirmando que

[...] a nocividade aqui não deriva da agressão de agente externo ao organismo humano, nem da natureza das substâncias porventura empregadas, mas do fato de se impor ao dispêndio do trabalho um padrão ritmo-intensidade desconforme com o padrão biológico.

[...] verifica-se "uma nocividade endógena pela imposição ao organismo humano de um padrão de atividade prejudicial ao seu bom funcionamento". ${ }^{323}$

Certos aspectos da fadiga foram identificados com o sofrimento e o desinteresse, ressalta Wisner, embora não sejam os únicos aspectos a serem registrados. ${ }^{324}$

${ }^{322}$ RIBEIRO, Herval Pina; LACAZ, Francisco A. de Castro. Agentes físicos e doenças. São Paulo: Departamento Intersindical de Estudos e Pesquisas de Saúde e dos Ambientes de Trabalho - DIESAT, 1984. p. 48.

${ }^{323}$ FREITAS JR., Antonio Rodrigues de. Tópicos da agenda protecionista na nova Constituição brasileira. Revista Jurídica do Trabalho, ano II, n. 5, p. 115-116, abr.-jun. 1989. 
Felice Battaglia observa com propriedade que, em relação ao dispêndio de energia e à fadiga, a natureza do trabalho intelectual não é diferente da do trabalho físico, na medida em que o primeiro não empenha somente vontade e nervos, funções psíquicas, mas também os músculos, assim como o segundo possui evidentes reflexos fora da esfera física. E, lastreando-se em Mosso, examina a fadiga em sua significação fisiológica, comparando-a a um envenenamento do sangue:

[...] Durante o trabalho produzem-se substâncias nocivas, uma das quais seria o ácido láctico, uma outra o ácido carbônico; acumulando-se, essas substâncias produzem os fenômenos da fadiga. Preferivelmente que venenos, são escórias ou imundícies que se originam dos processos químicos da vida e que, normalmente, são queimadas pelo oxigênio do sangue, ou destruídas pelo fígado, ou eliminadas pelos rins. Se estes detritos se acumulam no sangue, sentimo-nos cansados. Quando na verdade ultrapassamos o limite fisiológico, adoecemos. [.... ${ }^{325}$ (grifos nossos).

A realização de tarefas extenuantes e o trabalho exaustivo prestado em condições adversas chegam a provocar a morte por exaustão, muitas vezes de trabalhadores jovens, no início da idade produtiva.

No Japão, o psiquiatra Tetsunojo Uehata, que criou o vocábulo "karoshi”, que significa a morte causada pelo excesso de trabalho, informou em 1992 que os problemas do estresse quadruplicaram em dez anos. ${ }^{326}$ A respeito do "karoshi", diz Ricardo Antunes que o termo se refere à morte súbita no trabalho, provocada pelo ritmo e intensidade, que decorrem da busca incessante do aumento da produtividade. ${ }^{327}$

Exemplos de morte súbita no trabalho por exaustão serão analisados de forma mais detida quando do exame de determinadas atividades, como o trabalho no corte da cana-de-açúcar.

\footnotetext{
${ }^{324}$ WISNER, Alain. WISNER, Alain. Por dentro do trabalho: ergonomia: método \& técnica. São Paulo: FTD: Oboré, 1987. p. 39.

${ }^{325}$ BATTAGLIA, Felice. Filosofia do trabalho. São Paulo: Saraiva, 1958. p. 267.

${ }^{326}$ OLIVEIRA, Sebastião Geraldo de. Proteção jurídica à saúde do trabalhador. 5. ed. São Paulo: LTr, 2010. p. 179.

${ }^{327}$ ANTUNES, Ricardo. Adeus ao trabalho?: ensaio sobre as metamorfoses e a centralidade do mundo do trabalho. São Paulo: Cortez, 2010. p. 36.
} 
E a carga de trabalho implica intensidade, portanto, quantificação; impõe aceleração do ritmo de trabalho; a quantidade de trabalho e o ritmo acelerado, por sua vez, têm impacto não somente físico, como também psíquico, na medida em que a intensidade é determinada em função das metas a serem alcançadas.

José Antônio Ribeiro da Silva externa sua preocupação quanto à falta de definição de trabalho penoso, principalmente em relação ao trabalhador adolescente, ponderando que devem ser considerados o intenso esforço físico ou repetitivo e a excessiva atenção ou concentração no trabalho. ${ }^{328}$

E a terceira abordagem mencionada por Leny Sato relaciona o trabalho em condições penosas a sofrimento mental:

A terceira abordagem conta como exemplos com os estudos de Cooper e Sutherland (1987) e de Dejours (1980). A contribuição de Cooper e Sutherland [...] classificada em uma das bases de dados sob a palavrachave "heavy work", aborda a saúde mental em trabalhadores da indústria de extração de óleo e gás na plataforma, cuja atividade é reconhecida como perigosa, árdua e socialmente isolada.

Em sua obra Dejours (1980) utiliza-se do adjetivo "penoso" em pelo menos dois momentos de sua reflexão. No primeiro, ao situar a questão da adaptação a uma tarefa repetitiva e nova, acrescentando que nada é mais "penoso" para o trabalhador do que vivenciar esta fase do trabalho. Neste contexto, o autor parece utilizar-se do adjetivo "penoso", para qualificar o esforço e o sofrimento psíquico, a partir do qual se coloca a necessidade de manter as defesas coletivas, inclusive durante o tempo fora do trabalho. $[\ldots]^{329}$

O desgaste psíquico é provocado nas mais variadas situações de trabalho, conforme o tipo de atividade, descreve Edith Seligmann Silva, elencando os componentes da carga psíquica. Estes podem ser constituídos por variados sentimentos, como medo, repugnância, raiva, vergonha e outros. Diz essa autora que o medo pode resultar de um trabalho perigoso; em outras situações, é consequências da vivência de ataque à própria identidade ou resulta do sentimento de impotência ou fracasso na realização das próprias expectativas de desempenho. Exemplifica com o sentimento de responsabilidade, tipo de

\footnotetext{
${ }^{328}$ SILVA, José Antônio Ribeiro de Oliveira. A saúde do trabalhador na Constituição Federal e na legislação infraconstitucional - avaliação crítica. Disponível em: <http://camat.com.br/arquivos/ artigos/artigo_saude_do_trabalhador_na_cf_analise_critica_anamatra.pdf $>$. Acesso em: 9 nov. 2012.

${ }^{329}$ SATO, Leny. Conceito de trabalho penoso. Revista CIPA, São Paulo, v. 15, n. 179, p. 8, 1994.
} 
carga psíquica presente em atividade que envolve vidas humanas. ${ }^{330}$ Aqui se encontram os profissionais da área da saúde, como os médicos, os bombeiros, que enfrentam situações de risco para salvar vidas, os condutores de diferentes tipos de transporte, como piloto de avião.

Christophe Dejours sustenta que o sofrimento mental oriundo do trabalho tem como causa tanto o "conteúdo significativo" da tarefa quanto o "conteúdo ergonômico". Esse autor diz que o sofrimento operário é dividido em dois componentes, sem significar, com isso, que existam dois tipos distintos de sofrimento; são manifestados por meio de dois sintomas: a insatisfação e a ansiedade. Destaca Dejours que a maioria dos autores se interessa mais pela questão da satisfação da motivação do que pela da insatisfação. ${ }^{331}$

Ao modo como o "conteúdo significativo" da tarefa pode provocar sofrimento, esse autor salienta:

Do discurso operário podem-se extrair vários temas que se repetem obstinadamente como um refrão obsessivo. Não há um só texto, uma só entrevista, uma só pesquisa ou greve em que não apareça, sob suas múltiplas variantes, o tema da indignidade operária. Sentimento experimentado maciçamente na classe operária: o da vergonha de ser robotizado, de não ser mais que um apêndice da máquina, às vezes de ser sujo, de não ter mais imaginação ou inteligência, de estar despersonalizado etc. É do contato forçado com uma tarefa desinteressante que nasce uma imagem de indignidade. A falta de significação, a frustração narcísica, a inutilidade dos gestos, formam, ciclo por ciclo, uma imagem narcísica pálida, feia, miserável. Outra vivência, não menos presente do que a da indignidade, o sentimento de inutilidade remete, primeiramente, à falta de qualificação e de finalidade do trabalho. O operário da linha de produção como o escriturário de um serviço de contabilidade muitas vezes não conhecem a própria significação de seu trabalho em relação ao conjunto da atividade da empresa. Mas, mais do que isso, sua tarefa não tem significação humana. $[\ldots]^{332}$

Esse autor ensina que as frustrações resultantes de um conteúdo significativo inadequado às potencialidades e às necessidades da personalidade podem ser uma fonte de

\footnotetext{
${ }^{330}$ SILVA, Edith Seligmann. Trabalho e desgaste mental: o direito de ser dono de si mesmo. São Paulo: Cortez, 2011. p. 86.

${ }^{331}$ DEJOURS, Christophe. A loucura do trabalho: estudo de psicopatologia do trabalho. São Paulo: Cortez, 1988. p. 48.

${ }^{332}$ Idem, ibidem, p. 48-49.
} 
grandes esforços de adaptação. Explicita que as más condições de trabalho são menos temíveis que uma organização do trabalho rígida e imutável:

O sofrimento começa quando a relação homem-organização do trabalho está bloqueada; quando o trabalhador usou o máximo de suas faculdades intelectuais, psicoafetivas, de aprendizagem e de adaptação. Quando um trabalhador usou de tudo o de que dispunha de saber e de poder na organização do trabalho e quando ele não pode mais mudar de tarefa: isto é, quando foram esgotados os meios de defesa contra a exigência física. $[\ldots]^{333}$

E, ao estabelecer o liame entre insatisfação e conteúdo ergonômico do trabalho, Christophe Dejours destaca que essa vertente da satisfação do trabalho ocupa uma posição fundamental na problemática da relação saúde/trabalho:

Muitas vezes negligenciada ou desconhecida, a insatisfação resultante de uma inadaptação do conteúdo ergonômico do trabalho ao homem está na origem não só de numerosos sofrimentos somáticos de determinismo físico direto, mas também de outras doenças do corpo mediatizadas por algo que atinge o aparelho mental. [...]. ${ }^{334}$

Nessa linha, a última abordagem é a de que o "trabalho penoso" é aquele que demanda esforço físico e psíquico. A esse respeito, Wisner afirma que o sofrimento no trabalho é evidente quando se trata de uma sobrecarga física ou mental, e ilustra:

A repugnância às condições materiais do trabalho pode reforçar consideravelmente o sofrimento. Essa repugnância está muito ligada aos dejetos da atividade humana, a seu cheiro, a sua visão: coleta de lixo, trabalhos nos esgotos, nos abatedouros, em certas indústrias alimentícias, trabalhos no meio hoteleiro, hospitalar (roupa suja, limpeza, necrotério...).

Outros aspectos do sofrimento são de ordem psicológica e se multiplicam, em particular o contato com o usuário descontente, que não pode comunicar-se diretamente com os responsáveis pelo que ele considera injusto: serviços de emprego, guichê financeiro, vendedores etc. A transferência do descontentamento sobre o trabalhador que não é responsável pelo erro é cada vez mais frequente. [...]. ${ }^{335}$

${ }^{333}$ DEJOURS, Christophe. A loucura do trabalho: estudo de psicopatologia do trabalho. São Paulo: Cortez, 1988. p. 52.

${ }^{334}$ Idem, ibidem, p. 53.

${ }^{335}$ WISNER, Alain. Por dentro do trabalho: ergonomia: método \& técnica. São Paulo: FTD: Oboré, 1987. p. 40. 
E Antonio Rodrigues de Freitas realça que o trabalho sujo é uma das modalidades de trabalho penoso, assim considerado o realizado em circunstâncias geradoras de desagrado, desconforto e repugnância; nessa hipótese, há probabilidade de concomitância com exposição a agentes insalubres. ${ }^{336}$

Aqui podemos ilustrar com as atividades desempenhadas por trabalhadores da limpeza urbana, que limpam galerias pluviais, "bocas de lobo", bem como aqueles que se ativam com instalações de rede de esgoto, quando é comum o contato direto com substâncias, objetos ou situações repugnantes, inclusive cadáveres de animais.

No trabalho em necrotérios, com necropsia, bem como o de sepultadores, é ínsita a penosidade, na medida em que diariamente o trabalhador se depara com a morte, muitas vezes provocada por acidentes, traumas violentos ou delitos, e, ainda que se diga comumente que o trabalhador "se acostuma" com tal situação, cabe ponderar, ninguém se acostuma com a tragédia, com o fim da vida de forma traumática; não cabe confundir “tolerar" por necessidade de sobrevivência com aceitação.

Leny Sato assevera, reportando-se a estudos na área da ergonomia, psicopatologia do trabalho, psicofisiologia do trabalho, epidemiologia social, psicologia e sociologia, que não há a conceituação de "trabalho penoso" em nenhum deles. Os estudos terminam por focalizar a matéria nas situações concretas, que exigem esforço físico e mental, como o de Edith Seligmann Silva, que trata das prorrogações da jornada de trabalho:

Quanto mais prolongada for uma jornada de trabalho na qual um trabalhador necessite concentrar sua atenção, maior será o cansaço tanto físico quanto mental. Assim é que, atualmente, torna-se praticamente impossível, além de artificial, distinguir fadiga física de fadiga mental. E, quando o cansaço passa de fisiológico a patológico, isto é, quando o repouso e sono habituais não mais são capazes de superá-lo surge a fadiga crônica. ${ }^{337}$

Como mencionamos em capítulo anterior, o trabalho realizado em turnos, especialmente o trabalho noturno, é o que causa mais malefícios à saúde do trabalhador,

\footnotetext{
${ }^{336}$ FREITAS JR., Antonio Rodrigues de. Tópicos da agenda protecionista na nova Constituição brasileira. Revista Jurídica do Trabalho, ano II, n. 5, p. 116, abr.-jun. 1989.

${ }^{337}$ SILVA, Edith Seligmann. Crise econômica, trabalho e saúde mental. In: ANGERAMI-CAMON, Valdemar Augusto (Org.). Crise, trabalho e saúde mental no Brasil. São Paulo: Traço, 1986. v. 4, p. 62.
} 
como afirma Frida Marina Fischer. ${ }^{338}$ Neste tipo de jornada de trabalho, desrespeita-se o ciclo circadiano, de ativação psicossomática e de vigília durante o dia e de desativação e de sono durante a noite. Os riscos à saúde e de ocorrência de acidentes do trabalho, a sonolência no trabalho e a fadiga, associados ao trabalho noturno e em turnos, são alertados pela American Psychological Association. ${ }^{339}$

Cabe sustentar que o trabalho exercido em turnos ininterruptos de revezamento é realizado em condições penosas, como define Leny Sato, ao enquadrar o trabalho com “alternância de horários de sono e vigília ou de alimentação". De acordo com essa autora,

[...] essas condições de trabalho têm em comum o fato de exigirem esforço físico e/ou mental, provocarem incômodo, sofrimento ou desgaste da saúde. Elas podem provocar problemas de saúde que não são necessariamente doenças. ${ }^{340}$

Na doutrina italiana, há reconhecimento da penosidade do trabalho, quando prestado por sete dias consecutivos, sem repouso, com previsão de retribuição pelo desgaste psicofísico. ${ }^{341}$

E aqueles que trabalham muito, têm muitos compromissos e dormem pouco acabam sofrendo de um cansaço permanente, de estresse, ou de síndrome que

${ }^{338}$ FISCHER, Frida Marina. Organização do trabalho em turnos e noturno. Seminário realizado na Fundacentro, 20.08.2012.

339 "Nearly 15 million Americans work a permanent night shift or regularly rotate in and out of night shifts, according to the Bureau of Labor Statistics. That means a significant sector of the nation's work force is exposed to the hazards of working nights, which include restlessness, sleepiness on the job, fatigue, decreased attention and disruption of the body's metabolic process.

Those effects extend beyond the workers themselves, as many of us share the road with night-driving truckers, count on the precision of emergency-room workers and rely on the protection of police and national security personnel at all hours.

Now, psychologists are gaining a better understanding of how exactly night and shift work affect cognitive performance and which interventions and policies could keep shift workers and the public safer." Disponível em: <http://www.apa.org/monitor/2011/01/night-work.aspx>. Acesso em: 10 nov. 2012.

${ }^{340}$ SATO, Leny. Conceito de trabalho penoso. Revista CIPA, São Paulo, v. 15, n. 179, p. 41, 1994.

341 "A partire da Cass. S.U. n. 1607/89, si è consolidato l'indirizzo secondo il quale, nel caso di lavoro prestato nel settimo girono senza riposo compensativo, oltre alla retribuzione (con le relative maggiorazioni connesse alla maggiore penosità della prestazione), al lavoratore spetta anche il risarcimento del danno subito a causa dell'usura psico-fisica che il lavoro nel settimo giorno comporta, e ciò, naturalmente, ad un titolo del tutto autonomo rispetto a quello del compenso per la maggiore 'penosità' del lavoro." Disponível em: <http://www.di-elle.it/index.php?url=/consultazione/ giurisprudenza_2/riposo_settimanale_597/in_genere_598/view/598/>. Acesso em: 11 nov. 2012. 
recentemente ganhou novo nome: “jetlag social”. A síndrome, identificada pelo pesquisador Till Roenneberg, da Universidade de Munique, acontece em razão do descompasso entre os compromissos diários e o relógio biológico, e faz referência à fadiga provocada por viagens a cidades com o fuso horário diferente. Os sintomas são o sono sempre atrasado e, em um último estágio, a obesidade; são mais comuns nas mulheres, porque, além do trabalho, se encarregam dos afazeres domésticos, dos filhos, do marido e ainda levam tarefas para a casa: são as chamadas dupla e tripla jornadas. Esses sintomas vêm acompanhados de outra síndrome, a da pressa e a sensação de coração disparado, corpo lento e mente exausta. ${ }^{342}$

A forma de remuneração com o salário atrelado ao rendimento, o chamado pagamento por produção, é uma forma perversa de organização do trabalho, pois impulsiona o trabalhador a executar com maior rapidez as tarefas, contribuindo para um estado de fadiga geral. Laat e Rodolfo Vilela lembram que a Norma Brasileira de Ergonomia (NR-17 da Portaria 3.214/78 - Ministério do Trabalho e Emprego) não admite o pagamento por produção quando existem riscos à saúde dos trabalhadores, uma vez que este tipo de pagamento induz o trabalhador a ultrapassar os limites fisiológicos em busca de um rendimento financeiro extra. ${ }^{343}$

O trabalho penoso, como já dissemos, pode ser exercido na concomitância com exposição com agentes insalubres, como ruído contínuo ou intermitente, ruído de impacto, calor, radiações ionizantes, trabalho sob condições hiperbáricas, vibrações, frio, umidade, agentes biológicos, entre outros. Tais agentes constam da Norma Regulamentadora (NR) 15 da Portaria 3.214/1978 do Ministério do Trabalho e Emprego (MTE), que será examinada a seguir de forma mais detalhada.

Considerando a dificuldade de conceituação exposta, Christiani Marques contribui para sanar tal omissão, sustentando que o "trabalho penoso" pode ser conceituado como

${ }^{342}$ Disponível em: <http://oglobo.globo.com/saude/jetlag-social-um-novo-nome-para-estresse-5477489 \#ixzz2BwBAhN83>. Acesso em: 11 nov. 2012.

${ }^{343}$ LAAT, Erivelton Fontana de; VILELA, Rodolfo Andrade de Gouveia. A análise ergonômica do trabalho na colheita da cana-de-açúcar: proposta para redução do desgaste físico do trabalhador. Livro de Memórias do III Congresso Científico Norte-Nordeste - CONAFF. Disponível em: $<$ http://www2.sanny.com.br/pdf_eventos_conaff/Artigo06.pdf >. Acesso em: 9 nov. 2012. 
[...] aquele relacionado à exaustão, ao incômodo, à dor, ao desgaste, à concentração excessiva e à imutabilidade das tarefas desempenhadas que aniquilam o interesse, que leva o trabalhador ao exaurimento de suas energias, extinguindo-lhe o prazer entre a vida laboral e as atividades a serem executadas gerando sofrimento, que pode ser revelado pelos dois grandes sintomas: insatisfação e a ansiedade.

De acordo com Guilherme Guimarães Feliciano, a penosidade do trabalho configura-se pelo exercício do labor em condição laboral perversa, caracterizada pelos níveis anormais de desgaste humano, em vista do especial empenho físico ou psicológico que se exige do trabalhador. ${ }^{344}$

Destaca Leny Sato que as repercussões para a saúde, em decorrência do exercício desse tipo de trabalho, englobam a fadiga física e o desgaste mental. Tanto o esforço como a fadiga e o desgaste mental apenas caracterizarão o "trabalho penoso" quando estes forem acima de um nível supostamente tolerável. ${ }^{345}$

O trabalho penoso deve ser caracterizado levando-se em conta situações-limite em que não há medidas possíveis de controle ou de amenização, considerando-se o atual estágio das tecnologias e recursos disponíveis. Dessa forma, não se caracterizaria como penoso o trabalho em teleatendimento, quando a nocividade deriva do fato de o trabalhador ser submetido a imposições de metas inatingíveis e controle rígido, pois tais situações podem ser resolvidas com a substituição da chefia, por exemplo. Assim, se houver possibilidade de adoção de medidas que possam amenizar a situação, que não deriva da natureza nociva da própria atividade, mas de relações de trabalho "insalubres", equacionáveis por medidas organizativas, não resta configurada a circunstância de penosidade.

Salienta Freitas que sobressai no tocante ao trabalho penoso a existência de um vasto elenco de adversidades, às quais se sujeita o trabalhador, até o momento não

\footnotetext{
${ }^{344}$ Aula no Curso de Pós-Graduação da Faculdade de Direito da Universidade de São Paulo, disciplina "Saúde, Ambiente e Trabalho: novos rumos da regulação jurídica do trabalho I". 1. ${ }^{\circ}$ semestre de 2011.

345 SATO, Leny. Abordagem psicossocial do trabalho penoso: estudo de caso de motoristas de ônibus urbano. 1991. Dissertação (Mestrado) - Pontifícia Universidade Católica de São Paulo, p. 6.
} 
especificadas e de difícil classificação entre as hipóteses de exposição a agentes agressivos externos. $^{346}$

\subsubsection{Distinção entre insalubridade, periculosidade e penosidade}

Com o fito de bem delimitar a conceituação de trabalho penoso, cumpre antes efetuar a distinção entre o labor desempenhado em condições de penosidade, o trabalho insalubre e o desenvolvido em condições de periculosidade.

Ensina Sebastião Geraldo de Oliveira que os trabalhos insalubres e periculosos estão associados a determinados agentes agressivos, que normalmente causam doenças ou acidentes. Segundo esse autor,

[...] o trabalho insalubre é aquele exposto a agentes que podem afetar ou causar danos à saúde, provocar doenças, ou seja, é o trabalho não salubre, não saudável. Muitas enfermidades estão diretamente relacionadas e outras são desencadeadas, antecipadas ou agravadas pela profissão do trabalhador ou as condições em que o serviço é prestado. $[\ldots] .{ }^{347}$

Com a reforma do Capítulo V da CLT, levada a efeito pela Lei 6.514, de 22 de dezembro de 1977, o conceito de atividade insalubre foi definido de forma abrangente, conforme consta do artigo 189:

Serão consideradas atividades ou operações insalubres aquelas que, por sua natureza, condições ou métodos de trabalho, exponham os empregados a agentes nocivos à saúde, acima dos limites de tolerância fixados em razão da natureza e da intensidade do agente e do tempo de exposição aos seus efeitos.

A insalubridade somente foi mencionada na legislação brasileira na década de 30 do século passado, pois a Constituição de 1934 proibiu, no artigo 121, § 1. o, alínea "d", o trabalho insalubre para menores de 18 anos e para as mulheres.

\footnotetext{
${ }^{346}$ FREITAS JR, Antonio Rodrigues de. Tópicos da agenda protecionista na nova Constituição brasileira. Revista Jurídica do Trabalho, ano II, n. 5, p. 114, abr.-jun. 1989.

347 OLIVEIRA, Sebastião Geraldo de. Proteção jurídica à saúde do trabalhador. 5. ed. São Paulo: LTr, 2010. p. 165
} 
O caminho trilhado pelo Brasil tem sido o da "recompensa monetária" pela exposição aos riscos, em vez de priorizar os esforços na prevenção e na preservação da saúde do trabalhador. Nesse sentido, o primeiro diploma legal a instituir a monetização do risco foi o Decreto-lei 2.162, de 1. ${ }^{\circ}$ de maio de 1940, do Presidente Getúlio Vargas, que estabeleceu os adicionais de $40 \%, 20 \%$ e $10 \%$ sobre o salário mínimo, a título de insalubridade, de acordo com os graus máximo, médio e mínimo, exatamente como disciplina o atual artigo 192 da CLT.

A questão da base de cálculo tem sido objeto de acirrada polêmica em Tribunais Superiores, quando questionamentos surgiram acerca da inconstitucionalidade do artigo 192 da CLT, que fixa o salário mínimo como base de cálculo do adicional, pois o artigo 7. ${ }^{\circ}$, inciso IV, da Constituição da República impede a vinculação do salário mínimo para qualquer fim.

Submetida a questão da inconstitucionalidade do dispositivo consolidado à apreciação do Supremo Tribunal Federal, a mais alta Corte brasileira acabou por editar a Súmula Vinculante 4, publicada em 08.05.2008, que consagrou o entendimento de que o salário mínimo não pode ser utilizado como indexador de vantagem de servidor público ou empregado, in verbis: "Salvo nos casos previstos na Constituição, o salário mínimo não pode ser usado como indexador de base de cálculo de vantagem de servidor público ou de empregado, nem ser substituído por decisão judicial".

Assim, a Súmula Vinculante 4 tornou insubsistente a base de cálculo fixada no artigo 192 da CLT, mas não retirou o direito ao adicional. Ou seja, remanesce o direito à parcela, mas a base de cálculo não mais existe. Restou uma lacuna, que deve ser preenchida, sob pena de inviabilização do direito assegurado ao trabalhador.

A CLT, no art. 8. $^{\circ}$, permite ao juiz utilizar-se da analogia na falta de normas legais ou contratuais. Outrossim, é princípio geral que espécies semelhantes devem ser reguladas por normas semelhantes, podendo o intérprete lançar mão da analogia legis, que consiste em aplicar a uma hipótese não prevista em lei aquela disposição relativa a um caso semelhante; nesse passo poder-se-ia adotar a base de cálculo do adicional de periculosidade, o salário do empregado. No entanto, os Tribunais do Trabalho têm majoritariamente adotado o salário mínimo. 
De todo modo, tal questão não é a central, o foco principal deve ser sempre a saúde e a qualidade de vida do trabalhador. A eliminação total dos agentes insalubres ou mesmo a proibição do exercício de tais atividades beira a utopia; não se pode, por exemplo, proibir o atendimento dos doentes em hospitais. Portanto, sempre haverá trabalhadores expostos a agentes infectocontagiosos. Impõe-se, então, buscar formas alternativas e medidas que reduzem os riscos inerentes ao trabalho, à luz do inciso XXI do artigo $7 .^{\circ}$ da Constituição Federal.

As normas regulamentares do Ministério do Trabalho e Emprego consideram como agentes insalubres: ruído contínuo ou intermitente, ruído de impacto, calor, radiações ionizantes, trabalho sob condições hiperbáricas, radiações não ionizantes, vibrações, frio, umidade, agentes químicos, poeiras minerais e agentes biológicos. Tais agentes constam da Norma Regulamentadora (NR) 15 da Portaria 3.214/1978 do Ministério do Trabalho e Emprego (MTE).

Enquanto as atividades insalubres têm um conceito legal, o mesmo não ocorre com a periculosidade. Nesse caso, a legislação define de forma taxativa quais as hipóteses que conferem o direito à percepção do respectivo adicional. Nesse passo, como destaca Sebastião Geraldo de Oliveira, determinadas atividades, apesar de perigosas e de serem responsáveis pelos mais elevados índices de acidentes, como é o caso do trabalho na construção civil, não dão direito ao adicional de periculosidade. ${ }^{348}$

Observe-se que a prioridade deve ser sempre a eliminação ou minimização do risco, ou ainda a redução da jornada nos locais perigosos, e não sua monetização. De qualquer forma, ante impossibilidade de eliminação do agente periculoso, o adicional de periculosidade era devido, conforme a doutrina existente antes de recente alteração legal que ampliou as atividades consideradas perigosas:

“[...] aos exercentes de atividades que, por sua natureza ou métodos de trabalho, impliquem o contato permanente com inflamáveis, explosivos, energia elétrica e radiações ionizantes ou substâncias radioativas, excluídas outras quaisquer atividades que, embora literalmente

\footnotetext{
348 OLIVEIRA, Sebastião Geraldo de. Proteção jurídica à saúde do trabalhador. 5. ed. São Paulo: LTr,
} 2010. p. 173 
perigosas, por falta de previsão legal não estejam entre as quatro acima enumeradas. ${ }^{349}$

Cumpre dizer que, enquanto os agentes insalubres atuam lentamente, provocando efeitos a longo prazo, os agentes perigosos ou periculosos causam efeitos danosos imediatos, que podem levar à incapacidade ou à morte.

A primeira lei a tratar da matéria foi a de n. 2.573, de 15 de agosto de 1955, que instituiu o adicional de $30 \%$ sobre o salário percebido pelos empregados que trabalhavam em contato permanente com inflamáveis, em condição de periculosidade. Essa mesma lei facultava ao Ministério do Trabalho estender o benefício a outras atividades profissionais; tal diploma foi revogado pela Lei 6.514, de 22 de dezembro de 1977.

Os trabalhadores que exerciam atividades em contato permanente com explosivos passaram a reivindicar o adicional percebido pelos que laboravam com inflamáveis; assim, esse direito foi reconhecido por meio da Lei 5.880, de 24 de maio de 1973.

O Capítulo V da CLT é reformado pela Lei 6.514/1977, passando o artigo 193 da CLT a considerar perigosas as atividades desenvolvidas com contato com inflamáveis e explosivos; as hipóteses que geram o direito à percepção do adicional estão na NR-16 da Portaria 3.214/1978 do MTE.

Os eletricitários passaram então a reivindicar o direito ao recebimento do adicional de periculosidade, que foi instituído pela Lei 7.369, de 20 de setembro de 1985.

O adicional foi assegurado também aos trabalhadores expostos a radiações ionizantes ou substâncias radioativas, por meio da Portaria 3.393, de 17 de dezembro de 1987, revogada pela Portaria 496, sendo reinstituído o adicional pela Portaria 518, de 4 de abril de 2003. Tal questão foi objeto de acentuada polêmica em virtude de essa concessão não ter sido dada por meio de lei, até que a jurisprudência dos Tribunais do Trabalho foi sedimentada no sentido de que a exposição do empregado a radiação ionizante ou a substância radioativa enseja a percepção do adicional de periculosidade, pois a

\footnotetext{
${ }^{349}$ VALLE, Márcio Ribeiro do. In BARROS, Alice Monteiro de. Curso de direito do trabalho: estudos em
} memória de Célio Goyatá. São Paulo: LTr, 1993. v. 2, p. 207. 
regulamentação ministerial (Portarias do Ministério do Trabalho de $\mathrm{n}^{\text {os }} 3.393$, de 17.12.1987, e 518, de 04.04.2003), ao reputar perigosa a atividade, reveste-se de plena eficácia, porquanto expedida por força de delegação legislativa contida no artigo200, caput, inciso VI, da CLT. Assim, no período de 12.12.2002 a 06.04.2003, enquanto vigorou a Portaria 496 do Ministério do Trabalho, o empregado fez jus ao adicional de insalubridade. A matéria está pacificada no Tribunal Superior do Trabalho (TST), por meio do entendimento da Orientação Jurisprudencial 345 da SBDI-1. ${ }^{350}$

Publicada no Diário Oficial da União do dia 10.12.2012, a Lei 12.740, de 8 de dezembro de 2012, alterou o caput do artigo 193 da CLT, passando a considerar como atividades perigosas aquelas que, por sua natureza ou métodos de trabalho, impliquem risco acentuado em razão de exposição permanente do trabalhador a inflamáveis, explosivos, energia elétrica, bem como roubos ou outras espécies de violência física nas atividades profissionais de segurança pessoal ou patrimonial. Este diploma legal também revogou a Lei 7.369/1985, que previa o pagamento de adicional de periculosidade para os trabalhadores que se ativavam com energia elétrica, pela inclusão de tal atividade no inciso I.

E, ao considerar as atividades profissionais de segurança pessoal ou patrimonial como perigosas, a lei soluciona uma diferença que permeava duas categorias: os trabalhadores que transportavam valores por meio de carro-forte percebiam o adicional de risco, por força de norma coletiva, enquanto os vigilantes que laboravam em bancos, não. Com a previsão de que ambos os profissionais, tanto os que garantem a segurança pessoal quanto a patrimonial, fazem jus ao adicional de periculosidade, desaparece tal distinção. Nesse contexto, a Lei 12.740/2012 também prevê que serão descontados ou compensados do adicional outros da mesma natureza eventualmente já concedidos ao vigilante por meio de acordo coletivo.

\footnotetext{
350 TST, SDI-1, OJ 345. Adicional de periculosidade. Radiação ionizante ou substância radioativa. Devido. (DJ 22.06.2005). A exposição do empregado à radiação ionizante ou à substância radioativa enseja a percepção do adicional de periculosidade, pois a regulamentação ministerial (Portarias do Ministério do Trabalho n. 3.393, de 17.12.1987, e 518, de 07.04.2003), ao reputar perigosa a atividade, reveste-se de plena eficácia, porquanto expedida por força de delegação legislativa contida no art. 200, caput, e inciso VI, da CLT. No período de 12.12.2002 a 06.04.2003, enquanto vigeu a Portaria 496 do Ministério do Trabalho, o empregado faz jus ao adicional de insalubridade.
} 
Não obstante as semelhanças entre o trabalho prestado em condições insalubres e perigosas (agressão à saúde dos trabalhadores e forma de regulamentação), são flagrantes as diferenças entre um e outro, seja no aspecto técnico ou normativo. A primeira e grande diferenciação entre trabalho insalubre e trabalho periculoso é a forma de agressão sofrida pelo trabalhador, conforme propiciada por agente insalubre ou perigoso. O trabalho insalubre é aquele que afeta ou causa danos à saúde, provocando doenças, em face da agressão de agentes físicos, químicos ou biológicos. As agressões geradas pela insalubridade normalmente são percebidas a longo prazo, na medida em que o agente insalubre vai minando as resistências do organismo humano paulatinamente; já o trabalho periculoso pode levar à incapacidade ou morte súbita.

Outra importante diferenciação é efetuada por Antonio Rodrigues de Freitas, que afirma que a insalubridade, em qualquer de seus graus, se apresenta passível de eliminação mediante a utilização dos recursos oferecidos pela tecnologia desenvolvida no campo da engenharia de higiene ambiental, ao passo que a periculosidade jamais se mostra suscetível de eliminação. ${ }^{351}$

Sebastião Geraldo de Oliveira faz a distinção entre trabalhos insalubres, perigosos e penosos. Explica que os dois primeiros

[...] estão associados a determinados agentes agressivos que, normalmente, causam doenças ou acidentes. Entretanto, outras modalidades de trabalhos, sem acarretar diretamente doenças, provocam desgastes e até envelhecimento precoce, em razão da natureza do serviço, da forma de execução, do esforço requerido, da intensidade das tarefas, ou do seu caráter repugnante, incômodo ou desagradável. São denominados trabalhos penosos, nos quais o agente agressivo é o próprio serviço que se executa. Cabe mencionar, todavia, que não há limites precisos entre as agressões do trabalho penoso, insalubre ou estressante; em muitas ocasiões, essas agressões se confundem ou até se acumulam. $^{352}$

${ }^{351}$ FREITAS, Antonio Rodrigues de. Tópicos da agenda protecionista na nova Constituição brasileira. Revista Jurídica do Trabalho, ano II, n. 5, p. 111, abr.-jun. 1989.

352 OLIVEIRA, Sebastião Geraldo. Proteção jurídica à saúde do trabalhador. 5. ed. São Paulo: LTr, 2010. p. $173-174$. 
Ressalte-se que a prioridade deve ser a eliminação do agente agressor ou a adoção de medidas que reduzam a exposição do trabalhador aos riscos. A diminuição da jornada é uma alternativa, como foi analisada no capítulo que tratou da prevenção dos riscos.

Efetuada a exposição das características, que, por sua natureza, condições ou método de trabalho, tornam uma determinada atividade insalubre, periculosa ou penosa, cumpre, diante do exposto, conceituar trabalho penoso como aquele que é exercido com exigência de esforço físico e/ou mental com níveis anormais de desgaste, que é passível de exaurir as forças físicas e mentais, causando opressão, sofrimento, dor, ansiedade, exasperação, desânimo, tanto pela sobrecarga física das tarefas quanto pelo ritmo intenso de sua execução, pelo trabalho em condições agressivas e/ou repugnantes, pela imutabilidade das tarefas e alienação do conteúdo do trabalho, circunstâncias presentes em situação-limite, não passíveis de controle e amenização, no atual estágio das tecnologias e recursos disponíveis.

Os níveis anormais de desgaste físico ou psíquico são atingidos em razão de os trabalhadores serem submetidos aos chamados agentes estressores, físicos ou psicossociais, potentes no desencadeamento de doenças, que podem atingir tanto o operário como o executivo. A sobrecarga física ou psíquica de agentes estressores é um estado no qual as exigências do ambiente excedem a capacidade de adaptação do trabalhador. Além dos esforços físicos, os fatores principais que contribuem para a demanda excessiva de agentes estressores no trabalho são: urgência de tempo; responsabilidade excessiva; falta de apoio; expectativas excessivas de nós mesmos e daqueles que nos cercam. ${ }^{353}$ É o que ocorre, por exemplo, na busca de cumprimento de metas de produtividade inatingíveis, estabelecidas pelo empregador.

O trabalho exercido em condições agressivas confunde-se com a caracterização da insalubridade; assim, o trabalhador que desempenha suas atividades em exposição aos agentes agressivos submete-se aos agentes físicos - ruído, calor, radiações, frio, vibrações e umidade; ou aos agentes químicos - poeira, gases e vapores, névoas e fumos; ou agentes biológicos - micro-organismos, vírus e bactérias; e, muitas vezes, vários desses agentes

\footnotetext{
${ }^{353}$ Estresse e trabalho. Disponível em: <http://www.psiqweb.med.br/site/?area=NO/LerNoticia
} \&idNoticia=67>. Acesso em: 3 jan. 2013. 
estão concomitantemente presentes; além disso, tais condições agressivas, insalubres, somam-se à penosidade.

As condições repugnantes de trabalho, reiterando o ensinamento de Wisner, podem reforçar consideravelmente o sofrimento; essa repugnância está muito ligada aos dejetos da atividade humana, a seu cheiro, a sua visão: coleta de lixo, trabalhos nos esgotos, nos abatedouros, em certas indústrias alimentícias, trabalhos no meio hoteleiro, hospitalar (roupa suja, limpeza, necrotério...), entre outros. ${ }^{354}$

E para a compreensão do conceito de trabalho penoso é preciso ter claro que são ínsitos à sua caracterização, como já expusemos anteriormente, a forma de organização do trabalho; tarefa prescrita; meios materiais e equipamentos; a forma de produção e de remuneração; os aspectos ambiental e temporal na execução da tarefa. Todos ou alguns desses fatores, somados, apontam para uma situação-limite, sem possibilidade de controle ou amenização, pois, mesmo que sejam utilizados equipamentos de proteção individual (EPIs) ou equipamentos de proteção coletiva (EPCs), as condições laborativas que caracterizam a penosidade não são amenizadas. Para ilustrar, diga-se que a utilização de máscara, avental e luvas pelo responsável pela realização de necropsias não dá conta de amenizar as condições de trabalho; tais EPIs não afastam todas as circunstâncias que envolvem o contato habitual com cadáveres.

E, quando se afirma sobre a impossibilidade de controle e amenização de determinadas condições laborativas, no atual estágio das tecnologias e recursos disponíveis, quer-se dizer que não há possibilidade de tornar adequada e sadia aquela determinada forma de execução da atividade laborativa, mesmo com a aquisição e utilização dos equipamentos mais modernos existentes, sob pena de extinção do posto de trabalho. Como exemplo, conforme será destacado no próximo tópico, com o corte manual da cana-de-açúcar, há maior empregabilidade e péssimas condições de trabalho; com a implantação da colheita mecanizada, as condições de trabalho podem melhorar, mas aumenta o desemprego. Assim, ilustre-se, de nada adianta socorrer-se da robótica, por

${ }^{354}$ WISNER, Alain. Por dentro do trabalho: ergonomia: método \& técnica. São Paulo: FTD: Oboré, 1987. p. 40. 
exemplo: caso sejam colocados robôs para realizar tarefas penosas, perigosas, eles substituirão o homem.

O fato de não haver medidas possíveis de controle ou de amenização, diante do estágio atual dos recursos disponíveis, não deve eximir o empregador das responsabilidades decorrentes da exploração da mão de obra em tais circunstâncias, que propiciam adoecimento e morte dos trabalhadores, matéria que será abordada no capítulo seguinte.

\subsection{Exemplos de trabalho penoso}

Serão arrolados a seguir alguns exemplos de trabalhos penosos, que merecem destaque em razão das condições adversas em que são executados. Vale salientar que serão enfocadas atividades penosas, de acordo com o conceito ora proposto, no entanto nada impede que uma mesma atividade possa ter, concomitantemente, características de penosidade e periculosidade, ou de penosidade e insalubridade, ou tão somente ser considerada penosa. Reitere-se, o rol de atividades ora exposto está longe de ser exaustivo, é meramente exemplificativo.

\subsubsection{Corte de cana-de-açúcar e a morte por exaustão}

A cana-de-açúcar foi introduzida no período colonial no Brasil e se transformou em uma das principais culturas da economia brasileira. O Brasil é o maior produtor mundial de cana e o primeiro do mundo na produção de açúcar e etanol, e conquista, cada vez mais, o mercado externo com o uso do biocombustível como alternativa energética. ${ }^{355}$

O Estado de São Paulo é o maior produtor de cana-de-açúcar do Brasil, com cerca de três milhões de hectares de seu território utilizados no plantio dessa cultura, o que representa quase metade da área plantada no território nacional; apresenta alto nível de

\footnotetext{
${ }^{355}$ Disponível em: <http://www.agricultura.gov.br/vegetal/culturas/cana-de-acucar>. Acesso em: 10 nov.
} 2012. 
emprego de tecnologia de produção, constituindo o principal polo sucroalcooleiro do País. ${ }^{356}$

Não somente no Estado de São Paulo é usual a prática da despalha da cana-deaçúcar pela queima, mas ocorre também em outras unidades da federação, bem como em demais países, como Austrália, África do Sul, Estados Unidos, Argentina, Colômbia e outros. Dessa prática decorrem impactos causados na fase de cultivo, com a poluição do ar pela queima na despalha da cana, com consequências locais sobre a saúde e qualidade de vida, e globais, pela emissão de dióxido de carbono $\left(\mathrm{CO}^{2}\right)$, gás efeito estufa. Em razão disso e depois de reiterados apelos, deu-se a iniciativa do governo do Estado de São Paulo de extinção dessa prática. Em 1995, com a criação do Programa de Desenvolvimento de Competitividade (PDC) pelo governo estadual, foram estabelecidas várias câmaras setoriais para discussão de aspectos da competitividade, entre elas, do setor sucroalcooleiro. Surgiram propostas de acordo com os atores sociais relevantes, na busca de solução que atendesse a todos. ${ }^{357}$

Nesse sentido, prevê-se que praticamente toda a colheita paulista de cana-deaçúcar estará mecanizada até 2014, por força do Protocolo Ambiental firmado entre a entidade patronal dos produtores, a União da Indústria de Cana-de-Açúcar (Unica) e o governo do Estado de São Paulo.

O trabalho no setor canavieiro suscita paradoxos, pois com o corte manual há maior empregabilidade e péssimas condições de trabalho; com a implantação da colheita mecanizada, as condições de trabalho podem melhorar, mas aumenta-se o desemprego.

A esse respeito, estudo sobre as novas tecnologias e seus impactos sobre saúde do trabalhador, com a mecanização do corte da cana-de-açúcar, efetuado por pesquisadores da Universidade Estadual Paulista Júlio de Mesquita Filho (Unesp) de Araraquara;

\footnotetext{
${ }^{356}$ GERALDI, Cláudia Maria de Paula Eduardo et al. Estudo de caso: a questão da queima da palha da canade-açúcar: a difícil conciliação entre produção ambiental e desenvolvimento (proibição $\mathrm{x}$ autorização) dois aspectos do Estado em Juízo. in Direito ambiental e as funções essenciais à justiça: o papel da advocacia de estado e da defensoria pública na proteção do meio ambiente. Coordenação de Antonio Herman Benjamin e Guilherme José Purvin de Figueiredo. São Paulo: RT, 2011. p. 367.

${ }^{357}$ Idem, ibidem, p. 367-368.
} 
Universidade Federal de São Carlos (UFSCar); Universidade Estadual de Campinas (Unicamp) e Unesp de Jaboticabal, todas do interior do Estado de São Paulo:

A mecanização do corte da cana-de-açúcar no Estado de São Paulo, mais particularmente na região de Ribeirão Preto, está em estágio avançado e tem gerado discussões polêmicas entre os diferentes grupos sociais envolvidos com as problemáticas do trabalho, da saúde e, principalmente, do meio ambiente.

De um lado, os problemas ambientais gerados pela produção da cana-deaçúcar, do açúcar e do álcool (Marinho \& Kirchoff, 1991; Szmrecsányi, 1994) animam, principalmente, o movimento ambientalista, o Ministério Público e alguns parlamentares na defesa do fim, ou pelo menos da regulamentação, das queimadas nos canaviais. Uma vez que, do ponto de vista do rendimento e da segurança no trabalho, é prejudicial para o trabalhador o corte manual da cana crua, a alternativa que se coloca é a mecanização dessa atividade laboral. De outro lado, as empresas, valendo-se das atuais exigências do mercado e também das próprias ações dos movimentos sociais contra as queimadas e das denúncias e alertas que, desde as greves de Guariba e Leme, vêm sendo feitas para tentar resolver a questão social do boia-fria, mecanizam as lavouras, mas, cortando, principalmente, cana queimada. Na região de Ribeirão Preto, são queimados, aproximadamente, 650.000 hectares de cana por ano. Por outro lado ainda, com a crescente introdução de colhedeiras mecânicas, os trabalhadores assalariados rurais, organizados ou não, ressentem-se da diminuição dos postos de trabalho (Veiga Filho et al., 1994), da queda no valor real dos salários (Nogueira, 1992) e de uma sensível piora na qualidade das relações e condições de trabalho (Scopinho, 1995, 1996; Scopinho \& Valarelli, 1995). [...] ${ }^{358}$

Pode-se afirmar que em defesa do meio ambiente o Ministério Público tem sido bastante atuante. Como exemplo dessa atuação, citamos a Ação Civil Pública ajuizada perante a 1. ${ }^{a}$ Vara Federal de Jaú, Processo 2007.61.17.002615-9, tendo como autores o Ministério Público Federal e outros, e como réus, o Estado de São Paulo e outros. Nessa ação foi deferida a antecipação da tutela de mérito para:

[...] suspender imediatamente as autorizações a queima controlada da palha de cana-de-açúcar nas plantações situadas na área compreendida pela Subseção Judiciária Federal de Jaú, restando determinada a paralisação imediata da prática na região; [...]

\footnotetext{
358 SCOPINHO, Rosemeire Aparecida; EID, Farid; VIAN, Carlos Eduardo de Freitas; SILVA, Paulo Roberto Correia da. Novas tecnologias e saúde do trabalhador: a mecanização do corte da cana-de-açúcar. Cad. Saúde Pública, Rio de Janeiro, 15(1), p. 148, jan.-mar. 1999.
} 
Nas razões de decidir, o julgador destacou que a sentença focava a questão ambiental da região, e não o processo de produção:

[...] A decisão postada não tem o condão e muito menos objetiva determinar a paralisação do processo de produtivo dos derivados de cana-de-açúcar na região abrangida pela 17. a Seção Judiciária Federal. A única proibição que aqui expressa é quanto à manutenção da queima da palha da cana sem o prévio licenciamento ambiental, que, repita-se, deve ser feito pelo Ibama.[...]

Os trabalhadores no corte da cana, sem sombra de dúvida, são os que mais se expõem à fumaça e à fuligem provocada pela queima. Contudo, em que pese a justificada preocupação com os impactos ambientais, os estudos realizados e providências dos órgãos públicos têm como prioridade o cidadão que vive no entorno, e não aquele que trabalha diretamente exposto às condições adversas. Tanto é assimque Helena Ribeiro, em publicação de 2007, demonstra preocupação quanto a esses trabalhadores, mas revela que ainda precisa ser investigada a relação entre a queima da cana-de-açúcar e muitas mortes não explicadas nos canaviais; alerta que a substituição da queima e do corte manual pela colheitadeira somente propiciará melhoria das condições de saúde dos trabalhadores, se forem desenvolvidos programas para sua requalificação e absorção em outras funções:

[...] A queima da cana na pré-colheita objetiva, sobretudo, eliminar seu resíduo, a palha, para facilitar a colheita manual ou diminuir seu volume para incorporação ao solo. Dentre as dificuldades para a eliminação total da queima, prevista na lei paulista, estão restrições dos produtores quanto ao preço e deficiências da colheitadeira mecânica; e dos cortadores manuais, que ganham por produção e que conseguem maior produtividade e sofrem menores riscos com animais peçonhentos na cana queimada (Braunbeck \& Magalhães, 7, 2004; Weekes, 27, 2004). Os canaviais representam a maior demanda de força de trabalho agrícola no estado de São Paulo (35\%), sobretudo aquela com mais baixo nível de escolaridade (Braunbeck \& Magalhães, 7, 2004). Em adição, têm ocorrido muitas mortes não explicadas de trabalhadores em canaviais. Alves 2 (2006) atribui-as ao esforço físico em busca de maior produtividade no corte. No entanto, pode haver alguma relação entre a queima da cana e essas mortes, uma vez que exercício físico pesado realizado durante o corte, em local com muita fuligem, contribuiria para aumentar riscos à saúde respiratória. É uma relação que precisa ser investigada. [...]

A substituição da queima pela colheitadeira certamente beneficiará as condições de saúde das pessoas residentes nas áreas canavieiras. Entretanto, para constituir garantia de melhoria da saúde dos cortadores, 
é preciso que programas para sua requalificação e absorção sejam desenvolvidos e aplicados com urgência. $[. . .]^{359}$

Constata-se que existem esforços para a proteção do meio ambiente, enquanto o meio ambiente do trabalho muitas vezes é ignorado. O trabalhador no corte da cana-deaçúcar enfrenta várias outras condições adversas, além de aspirar a fumaça e a fuligem que são expelidas com a queima.

O corte manual da cana-de-açúcar, segundo informações, é caracterizado por movimentos repetitivos dos braços, pernas e tronco, podendo ser feito sob duas condições: cana crua e cana queimada, explicam Laat e Rodolfo Vilela. No corte da cana crua, o cortador, usando um facão, elimina a palha e, a seguir, corta a cana rente ao solo e na ponta. Alessi e Scopinho (1994) indicam que um cortador de cana-de-açúcar de sexo masculino pode alcançar a produção máxima de 14 toneladas/dia, e do sexo feminino, 10 toneladas/dia. O sistema de pagamento por produção, associado à precarização dos alojamentos, meios de transporte, alimentação insuficiente e condições trabalho nocivas, sem pausas para descanso, pode agravar os riscos de acidentes e o desgaste prematuro destes trabalhadores. ${ }^{360}$

De acordo com dados do início de 2011 da Secretaria Estadual de Saúde de São Paulo, decorrentes das inspeções da Vigilância Sanitária, o ritmo de trabalho desses trabalhadores é determinado por:

- 17 flexões de tronco por minuto;

- 54 golpes de facão por minuto;

- 12 toneladas de cana cortadas e carregadas por dia;

- percurso de 9 quilômetros/dia;

- perda de 8 litros de água na jornada diária. ${ }^{361}$

${ }^{359}$ RIBEIRO, Helena. Queimadas de cana-de-açúcar no Brasil: efeitos à saúde respiratória. Rev. Saúde Pública, 42(2), p. 375, 2008.

${ }^{360}$ LAAT, Erivelton Fontana de; VILELA, Rodolfo Andrade de Gouveia. A análise ergonômica do trabalho na colheita da cana-de-açúcar: proposta para redução do desgaste físico do trabalhador. Livro de Memórias do III Congresso Científico Norte-Nordeste - CONAFF. Disponível em: $<$ http://www2.sanny.com.br/pdf_eventos_conaff/Artigo06.pdf>. Acesso em: 9 nov. 2012.

${ }^{361}$ Revista do Brasil, n. 59, p. 12-17, maio 2011. 
Além disso, no dizer de Christophe Dejours, há sofrimento no que tange ao "conteúdo ergonômico" do trabalho, pois as pernas ficam o tempo todo semiflexionadas e há extensão da região cervical da coluna.

Os exercícios físicos realizados em condições adversas por esses trabalhadores foram estudados por Cristiane Maria Galvão Barbosa, em tese de doutorado cujo objetivo foi avaliar a ocorrência de efeitos cardiovasculares e respiratórios e possíveis mecanismos implicados nos mesmos, associados ao trabalho no corte de cana-de-açúcar queimada. Este estudo destacou as seguintes situações:

O trabalhador ao chegar ainda cedo no canavial enfrenta em seu ambiente de trabalho, temperatura bastante elevada, decorrente do aquecimento pela queima da cana e que pode se intensificar durante o dia pela ação solar. Deste modo, o calor pode ser um fator de risco que, somado ao exercício excessivo, pode levar a hipertermia e desidratação.

O desconforto térmico e a hipertermia também são aumentados pelo uso de vestimentas grossas e sobrepostas, uma vez que se faz necessária proteção para todo corpo: botina, perneira de couro até o joelho, calças grossas, camisa de manga comprida com mangote, luvas, lenço no pescoço e chapéu. Estas vestimentas dificultam a dissipação de calor, aumentado a possibilidade de ocorrência de hipertemia.

Ao longo da jornada para compensar a perda de líquido pelo suor, o cortador ingere bastante água. A prática das usinas em fornecer "repositores" é feita de maneira igual para todos, não sendo possível avaliar se atende às variações de cada indivíduo. $[\ldots]^{362}$

Explica essa pesquisadora os mecanismos desenvolvidos pelo corpo humano para manter a homeostasia, ${ }^{363}$ bem como o que ocorre com o organismo quando os exercícios são de intensidade moderada ou quando os esforços são intensos: ${ }^{364}$

${ }^{362}$ BARBOSA, Cristiane Maria Galvão. Avaliação cardiovascular e respiratória em um grupo de trabalhadores cortadores de cana-de-açúcar queimada no estado de São Paulo. 2010. Tese (Doutorado em Ciências. Programa de Pneumologia) - Faculdade de Medicina da Universidade de São Paulo, São Paulo, p. 4-5.

${ }^{363}$ Esse termo é utilizado para designar a manutenção das condições estáveis ou constantes no meio interno. Essencialmente, todos os órgãos e tecidos do corpo desempenham funções inter-relacionadas que ajudam a manter constantes tais condições.

Disponível em: <http://portaldoprofessor.mec.gov.br/fichaTecnicaAula.html?aula=1716>. Acesso em: 4. jul. 2011.

364 "Durante o exercício físico o organismo aumenta o consumo de oxigênio para suprir as necessidades dos músculos em movimento. Este processo leva a uma série de respostas orgânicas, no sentido de manter a homeostasia interna. Estas respostas são reguladas tanto a nível central, como a nível periférico. $\mathrm{O}$ 
Entretanto em condições de exercício físico vigoroso por período prolongado o organismo não consegue manter a homeostasia e um quadro patológico pode se instalar. No caso do atleta esta situação é denominada de "Síndrome de Overtraining".

A "Síndrome de Overtraining" é compreendida por sinais e sintomas caracterizados por diminuição da performance, fadiga, alterações do sono, diminuição de peso, aumento dos níveis séricos de lactato, alterações hormonais, imunológicas hematológicas e psicológicas.

Entretanto, não existem marcadores específicos que caracterizem a presença da síndrome e os seus mecanismos fisiopatológicos não estão completamente esclarecidos.

É provável que na atividade de corte de cana devido ao ritmo de trabalho intenso, os ajustes fisiológicos que ocorrem em resposta ao exercício físico não consigam dar suporte à demanda do organismo para manter o equilíbrio interno, e com isto resposta anômala e/ou patológica passe a ocorrer, refletindo em níveis diversos de fadiga e insuficiência dos músculos envolvidos no trabalho e de órgão alvos exigidos acima do limite e analogamente ao que ocorre com os atletas, estes trabalhadores podem desenvolver quadro semelhante a "Síndrome de Overtraining".

A fadiga, segundo Rossi L, pode ser definida como um conjunto de alterações causadas pelo trabalho ou exercício prolongado, que leva a uma diminuição da capacidade funcional de manter o rendimento esperado. Entre os cortadores de cana é frequente a referência a fadiga.

Agravando ainda mais a situação destes trabalhadores outras manifestações patológicas podem também estar presentes decorrentes da ação do calor durante o corte de cana.

As manifestações clínicas da exposição ao calor são em geral inespecíficas e de caráter progressivo. Inicialmente aparece o edema de membros inferiores, devido à vasodilatação periférica. Em seguida é comum a aparição de câimbras, que ocorre pelo desequilíbrio hidroeletrolítico, sendo este sintoma um alerta sobre a possibilidade de lesões mais graves decorrentes do calor excessivo. Se o quadro evoluir, sintomas de exaustão com a presença de bradicardia, hipotensão e síncope podem se manifestar e finalmente um quadro de hipertermia

Sistema Nervoso Central induz a alterações no sistema nervoso autônomo, com estimulação da atividade simpática e diminuição da atividade parassimpática, durante o exercício, atuando assim no sistema cardiovascular levando, entre outras alterações, a aumento da frequência cardíaca e do volume sistólico, com consequente aumento do débito cardíaco, assegurando maior aporte de oxigênio e nutrientes aos músculos durante o exercício.

Quando a carga de exercício é constante e de intensidade moderada o organismo se adapta a esta nova condição de maneira que os efeitos benéficos do exercício físico são sentidos e se associam principalmente a menor prevalência de doenças crônico-degenerativas, como eventos cardiovasculares" (BARBOSA, Cristiane Maria Galvão. Avaliação cardiovascular e respiratória em um grupo de trabalhadores cortadores de cana-de-açúcar queimada no estado de São Paulo. 2010. Tese (Doutorado em Ciências. Programa de Pneumologia) - Faculdade de Medicina da Universidade de São Paulo, São Paulo, p. 5-6). 
poderá se instalar podendo levar à morte, se medidas terapêuticas não forem tomadas a tempo. ${ }^{365}$

Pesquisas realizadas pela Fundacentro, para monitorar em todo o País a exposição ao calor dos trabalhadores rurais, revelam acerca da sobrecarga térmica que:

A exposição a ambientes quentes combinada com a alta produção interna de calor devido a execução de tarefas que exigem esforço físico leva o corpo à necessidade de uma rápida perda de calor do corpo a fim de preservar o seu equilíbrio térmico.

A céu aberto, a maioria dos trabalhadores precisa utilizar vestimentas, que cobrem quase todo o corpo, o que dificulta a perda de calor. A combinação dessas condições pode levar os trabalhadores à sobrecarga térmica e provocar, câimbras, fadiga severa e repentina, náuseas, vertigens, perda da consciência e, eventualmente, à morte. ${ }^{366}$

O pagamento por produção agrava a situação do trabalho na cana-de-açúcar, pois incentiva o incremento do ritmo de trabalho, para manter a produtividade e os rendimentos dela decorrentes. Esse sistema determina que o valor do pagamento dependa da quantidade de cana cortada; o valor é definido em toneladas e o trabalhador não tem controle sobre a produção. Todos os fatores somados fazem com que, para assegurar sua subsistência, o trabalhador labore até a exaustão:

No pagamento por produção, as usinas usam um complicado sistema de medidas que impossibilita ao trabalhador ter um controle sobre a quantidade cortada e sobre o valor do pagamento. Como a quantidade de cana cortada é medida em metros lineares e o valor é definido em toneladas, torna-se necessário a conversão do valor de tonelada para o valor de metro de cana cortada. Este procedimento é feito pela usina.

${ }^{365}$ BARBOSA, Cristiane Maria Galvão. Avaliação cardiovascular e respiratória em um grupo de trabalhadores cortadores de cana-de-açúcar queimada no estado de São Paulo. 2010. Tese (Doutorado em Ciências. Programa de Pneumologia) - Faculdade de Medicina da Universidade de São Paulo, São Paulo, p. 6-7.

${ }^{366}$ De 2009 a 2011 a unidade da Fundacentro em Campinas desenvolveu tecnologia e produziu um software para monitorar em todo o País a exposição ao calor dos trabalhadores rurais utilizando dados provenientes das estações meteorológicas do Instituto Nacional de Meteorologia (INMET). Em 2012 disponibilizará, via internet, este software que terá abrangência, primeiramente, nos Estados de São Paulo, Minas Gerais, Rio de Janeiro, Paraná, Mato Grosso do Sul.

O objetivo desta pesquisa foi dar um passo no sentido do trabalho seguro e saudável no campo e em áreas urbanas abertas fornecendo às empresas responsáveis uma ferramenta gratuita de gestão para monitorarem as condições térmicas de seus funcionários no trabalho a céu aberto, evitando o adoecimento dos trabalhadores, bem como evitando as perdas econômicas decorrentes destes infortúnios. Disponível em: <http://www.fundacentro.gov.br>. Acesso em: 3 dez. 2012. 
A falta de controle da produção e do valor do pagamento pelos trabalhadores é o principal meio de pressão dos usineiros para aumentar a produtividade do trabalho, pois se os trabalhadores soubessem quanto ganhariam teriam a possibilidade de interromper o trabalho quando tivessem chegado ao limite de sua resistência física. ${ }^{367}$

Além disso, a cana de açúcar transgênica, mais leve e com maior nível de sacarose, vem exigindo dos trabalhadores um esforço ainda maior para atingir a tonelada, e é o peso que define o valor. Isto significa mais lucros para os usineiros e mais exploração para os trabalhadores.

Segundo pesquisa do Ministério do Trabalho e Emprego (MTE), "antes $100 \mathrm{~m}^{2}$ de cana somavam 10 toneladas, hoje são necessários $300 \mathrm{~m}^{2}$ para somar 10 toneladas". Esse padrão de exploração tem causado sérios problemas de saúde e até a morte dos trabalhadores. Entre 2004 e 2007 foram registradas 21 mortes por exaustão no corte da cana. "O açúcar e o álcool no Brasil estão banhados de sangue, suor e morte", afirma a pesquisadora Maria Cristina Gonzaga, da Fundacentro, um órgão do Ministério do Trabalho. ${ }^{368}$

Como foi dito, ocorre o chamado "karoshi", termo que se refere à morte súbita no trabalho, provocada pelo ritmo e intensidade, que decorrem da busca incessante do aumento da produtividade.

Registre-se que o Ministério Público do Trabalho tem atuado em parceria com demais órgãos públicos com o objetivo de impedir que a expansão das usinas e açúcar e álcool se dê em função de condições de trabalho desumanas. A iniciativa tem como objetivo o fim das jornadas exaustivas e melhores condições de conforto nos locais de trabalho. Entre as principais ações está a atuação nacional para identificar os problemas e adotar medidas judiciais e extrajudiciais para adequação das condições ambientais no

${ }^{367}$ Os agrocombustíveis no Brasil - Informe da Missão de Investigação sobre os impactos das políticas públicas de incentivo aos agrocombustíveis sobre o desfrute dos direitos humanos à alimentação, ao trabalho e ao meio ambiente, das comunidades campesinas e indígenas e dos trabalhadores rurais no Brasil, maio 2008. Disponível em: <http://www.boell-latinoamerica.org/downloads/resumo__dh_e_industria_da_cana1.pdf $>$. Acesso em: 4 jul. 2011.

${ }^{368}$ Idem, ibidem. 
trabalho para buscar: o fim das jornadas exaustivas; a exigência do uso de Equipamentos de Proteção Individual (EPIs); e adequação das frentes de trabalho e alojamentos. ${ }^{369}$

No entanto, ressalta Cristiane Maria Galvão Barbosa, quando da realização da sua pesquisa em 2010, nenhum estudo havia sido efetuado para investigar as causas das mortes dos trabalhadores no corte da cana-de-açúcar:

Nos últimos anos, inúmeras denúncias têm sido realizadas, por parte de instituições públicas - Universidades, Ministério Público, Ministério do Trabalho, o Legislativo de várias esferas da Federação - de sindicatos de trabalhadores rurais e da imprensa, sobre a ocorrência de mortes de cortadores de cana, sem que causas sejam estabelecidas.

É possível que este somatório de riscos presentes na atividade laboral destes trabalhadores esteja contribuindo para estes óbitos, porém até o momento nenhum estudo foi realizado no sentido de investigar as possíveis causas e fatores relacionados a estas mortes. ${ }^{370}$

Registram-se melhorias localizadas, como na região de Ribeirão Preto, em São Paulo: fornecimento de água gelada, lugar para sentar e almoçar, jornada de trabalho das $7 \mathrm{~h}$ às $16 \mathrm{~h}$ (já chegou a 12 horas diárias) e trabalhadores registrados em carteira.

No entanto, são avanços específicos dessa região de São Paulo. De forma geral, a superexploração do trabalhador permanece como regra no setor. Essa é uma realidade absolutamente intolerável para um país que ostenta o modelo de energia limpa e renovável, para todo o mundo, na produção da cana-de-açúcar.

Não é possível aceitar que a preocupação com o meio ambiente tenha destaque, e o ser humano, o trabalhador, continue sendo tratado como uma peça de reposição, muito mais barata que as máquinas que poderão substituí-lo.

\footnotetext{
${ }^{369}$ Disponível em: <www.http://portal.mpt.gov.br/wps/portal/portal_do_mpt/sobre_o_mpt/programas nacionais $>$. Acesso em: 16 jun. 2011.

${ }^{370}$ BARBOSA, Cristiane Maria Galvão. Avaliação cardiovascular e respiratória em um grupo de trabalhadores cortadores de cana-de-açúcar queimada no estado de São Paulo. 2010. Tese (Doutorado em Ciências. Programa de Pneumologia) - Faculdade de Medicina da Universidade de São Paulo, São Paulo, p. 13.
} 


\subsubsection{Motoristas de ônibus urbano}

Pode-se afirmar, pelo senso comum, que o trabalho puramente prazeroso e confortável não existe. No entanto, quando qualificado como "penoso", diz Leny Sato,

[...] quer-se dizer que além do esforço característico do trabalho há um "a mais" que o transforma em castigo, punição, desconforto e sofrimento. Parece, portanto, que o "trabalho penoso" comporta uma dimensão quantitativa - a mais - e outra qualitativa, dado que a característica do trabalho é transformada. ${ }^{371}$

Nesse sentido, essa pesquisadora, ao fazer a introdução de seu objeto de estudo, reportou-se à reivindicação efetuada em 1971 pelo representante do Sindicato dos Condutores de Veículos e Anexos de Nova Iguaçu (RJ), durante o X Congresso Nacional de Prevenção de Acidentes do Trabalho, que consistia na criação de um "adicional de penosidade" e a redução da jornada diária de trabalho para seis horas, em benefício dos motoristas profissionais.

Sustentou o dirigente sindical que a reivindicação não era de percepção dos adicionais legalmente previstos, uma vez que para ele o trabalho do motorista envolve uma dimensão da relação "saúde e trabalho", não contemplada pelos conceitos de insalubridade e de periculosidade, que por ele foi denominada de "penosidade". 372

Os elementos arrolados, contidos na condição de trabalho do motorista, que para a autora parecem traduzir a concepção de "trabalho penoso", são os seguintes:

Não só para os técnicos em medicina do trabalho, como também para os leigos atentos ao desenvolvimento social, evidencia-se sem grande esforço de observação, que os motoristas profissionais, pelas peculiaridades de sua atividade profissional, desenvolvem intensa atividade física e mental, simultâneas, não só pela realização do trabalho em si como também, ante a complexidade do tráfego rodoviário urbano e de estradas, que os submetem a uma permanente concentração do sistema nervoso, à fixação de atenção, à responsabilidade pelas vidas e pelo patrimônio sob sua guarda, cotidianamente.

O sistema nervoso dos profissionais do volante está sujeito a pressões simultâneas e várias, das quais estão isentos os outros trabalhadores. O

\footnotetext{
${ }^{371}$ SATO, Leny. Abordagem psicossocial do trabalho penoso: estudo de caso de motoristas de ônibus urbano. 1991. Dissertação (Mestrado) - Pontifícia Universidade Católica de São Paulo, p. 12-13.

${ }^{372}$ Idem, ibidem, p. 2.
} 
elevado valor dos veículos, as vidas sob sua responsabilidade, a vida dos pedestres afoitos, a sinalização muitas vezes defeituosa, o excesso de ruídos, muito acima da taxa de decibéis além do suportável pelo organismo humano, o calor que se desprende do motor, o ar viciado dos coletivos, a fumaça dos canos de escapamento, a conformação antianatômica das poltronas dos motoristas, são entre outros, fatores de cansaço e fadiga. ${ }^{373}$

Por essas razões o Projeto de Lei 957/1991 considerou penosa e perigosa a atividade laborativa do motorista profissional, tendo como justificativa, como lembra Christiani Marques,

[...] que tal trabalhador vive sob perigo constante, tanto nas vias públicas urbanas quanto nas rodovias, além dos assaltos a que estão sujeitos e que configuram uma permanente ameaça a sua incolumidade física. Destaca que essa atividade é penosa porque envolve muita atenção ao volante, o que gera bastante tensão e stress, fazendo com que esses profissionais fiquem, precocemente, com suas energias exauridas. ${ }^{374}$

Ocorre que tal propositura foi arquivada, tendo em vista a aprovação pela Câmara dos Deputados, em 10 de dezembro de 2009, do Projeto de Lei 99, de 2007, de autoria do Deputado Tarcísio Zimmermann, que "Dispõe sobre o exercício da profissão de motorista". Assim, restou declarada a prejudicialidade dos Projetos de Lei 1.624/2007, 675/1991, 957/1991, 5.580/2001, 5.581/2001 e 5.582/2001, conforme publicação do Diário da Câmara de 26.05.2010. ${ }^{375}$

O Projeto de Lei 99/2007, embora não tenha conceituado a "atividade penosa", previu no seu artigo $3 .^{\circ}$ que "o exercício das atividades reguladas pela presente lei assegura a percepção de adicional de penosidade correspondente a, no mínimo, 30\% (trinta por cento) da remuneração mensal". A propositura foi enviada ao Senado Federal e aguarda retorno à Mesa Diretora da Câmara.

De iniciativa do Deputado Federal Paulo Paim, o Projeto de Lei 7.083/2002, que disciplina a jornada de trabalho e concede adicional de penosidade, aposentadoria especial

\footnotetext{
${ }^{373}$ SATO, Leny. Abordagem psicossocial do trabalho penoso: estudo de caso de motoristas de ônibus urbano. 1991. Dissertação (Mestrado) - Pontifícia Universidade Católica de São Paulo, p. 13.

${ }^{374}$ MARQUES, Christiani. A proteção ao trabalho penoso. São Paulo: LTr, 2007. p. 64.

375 Disponível em: <http://camara.gov.br>. Acesso em: 4 jul. 2011.
} 
e seguro obrigatório aos motoristas e cobradores de transportes coletivos urbanos, foi apensado ao Projeto de Lei 1.113/1988, que dispõe sobre a profissão de motorista de transportes coletivos urbanos e interurbanos. Este se encontra pronto para votação em plenário e prevê que a jornada de trabalho dos motoristas que trabalham em turno de revezamento será de seis horas diárias, ficando vedada a prorrogação da jornada noturna.

As condições de trabalho a que se sujeita em especial o motorista de ônibus urbano, por si só suficientes para caracterização de atividade "penosa", pois enfrenta trânsito caótico e violento, em particular nos grandes centros; transita por ruas esburacadas, sofrendo "solavancos", com consequências prejudiciais à coluna, além dos problemas posturais, dificuldade de realizar pausas para refeição, ida ao banheiro etc., tornam-se ainda mais difíceis com as costumeiras prorrogações das jornadas de trabalho. Muito comum também é o cumprimento da jornada prolongada sem a devida contraprestação, sob o argumento patronal de que não está sujeito a controle de jornada, restando ao trabalhador a busca da tutela judicial, para fazer valer seu direito.

Por isso, Leny Sato, na realização do seu estudo, depreendeu que o "trabalho penoso" para esta categoria está relacionado a:

[...] um conjunto de fatores constitutivos da condição de trabalho do motorista profissional, englobando desde a presença de agentes de natureza física como ruído e calor; química, como a fumaça do escapamento; de adequação do equipamento como as poltronas; as condições das estradas e vias; a responsabilidade com o carro, com os passageiros e pedestres; o tráfego, dentre outros. Não é possível identificar e eleger um agente específico da condição de trabalho do motorista profissional, capaz de sintetizar a noção de "trabalho penoso". Além disso está relacionado com o desgaste físico e mental, desencadeando o cansaço e a fadiga.

Esta condição de trabalho é por ele relacionada às ocorrências de acidentes de trânsito, dada a fadiga que ela engendra ocasionando o retardamento do reflexo, a redução da acuidade sensorial, diminuindo a produtividade no trabalho e conduz à subestimação do perigo. ${ }^{376}$

A pesquisadora Leny Sato empregou o que chama de "palavra índice" no seu estudo, e o termo "irritação" se constitui para o motorista como sinalizador do limite

${ }^{376}$ SATO, Leny. Abordagem psicossocial do trabalho penoso: estudo de caso de motoristas de ônibus urbano. 1991. Dissertação (Mestrado) - Pontifícia Universidade Católica de São Paulo, p. 13-14. 
subjetivo do suportável, nas dimensões física e mental. Incômodos, esforços e irritações existem em todos os contextos de trabalho, diz. Entretanto, na linguagem dos motoristas, a expressão "Linha Pesada" já denota quantificação subjacente; assim, é aquela que tem "muito passageiro", "muito trânsito" e "paradas demais".

Nesse sentido, o trabalho é "penoso" quando se dá mais do que é possível, por excesso ou por inconveniência de estímulos, por exemplo, o excesso de jornada, sem a devida contraprestação.

Outro registro importante na mencionada pesquisa é o de que o trabalho é "complicado", "ruim", quando há descontrole sobre o seu ritmo, bem como quando o trabalhador se sente manietado, sem poder para agir:

O trabalho é "penoso" quando o trabalhador não tem conhecimento, poder e instrumentos para controlar os contextos de trabalho que suscitam vivências de desconforto e desprazer, dadas as características e necessidades e limites subjetivos. Enfim, o trabalho é "penoso" quanto o trabalhador não é sujeito da situação. Quando isto ocorre, o trabalho é sentido como "desumano, forçado". 377

Essa autora conclui seu trabalho afirmando que, apesar de ter adotado os motoristas de ônibus como base empírica desse estudo, entende que as conclusões extraídas podem ser extrapoladas para a análise do trabalho penoso em outras categorias profissionais.

\subsubsection{Turno ininterrupto de revezamento}

A Constituição Federal de 1988 assegura a jornada de trabalho reduzida de seis horas, quando há turnos ininterruptos de revezamento. ${ }^{378}$

\footnotetext{
377 SATO, Leny. Abordagem psicossocial do trabalho penoso: estudo de caso de motoristas de ônibus urbano. 1991. Dissertação (Mestrado) - Pontifícia Universidade Católica de São Paulo, p. 71-72.

378 "Art. 7. ${ }^{\circ}$ São direitos dos trabalhadores urbanos e rurais, além de outros que visem à melhoria de sua condição social: [...]

XIV - jornada de seis horas para o trabalho realizado em turnos ininterruptos de revezamento, salvo negociação coletiva."
} 
Historicamente, o objetivo do constituinte, ao inserir referido artigo na Carta Magna, foi o de coibir a proliferação indiscriminada dos turnos ininterruptos de revezamento de oito horas que permeavam as atividades industriais por aplicação analógica do disposto na Lei 5.811/1972, que trata do regime laboral nas atividades de exploração, perfuração, produção e refinação de petróleo, industrialização do xisto, na indústria petroquímica e no transporte de petróleo e seus derivados por meio de dutos $\left(\operatorname{artigos} 1 .^{\mathrm{o}}\right.$ e $\left.2 .^{\mathrm{o}}, \S 1 .^{\mathrm{o}}\right) .^{379}$

O tema tem propiciado intenso debate doutrinário e jurisprudencial quanto à validade jurídica da negociação coletiva, enquanto ressalva à regra geral insculpida no artigo $7^{\circ}$, inciso XIV, da Lei Maior.

De início, cumpre dizer que a regra estabelecida pela Constituição da República, da jornada reduzida, é norma de tutela da saúde do trabalhador, dado que a forma de revezamento ininterrupta é prejudicial ao homem.

Nesse sentido, a doutrina, conforme estudos desenvolvidos pelo Departamento Intersindical de Estudos e Pesquisas de Saúde e dos Ambientes de Trabalho (Diesat):

"O regime de trabalho em turnos alternados (rodízio ou revezamento) passa a ser cada vez mais frequente nas indústrias e mesmo no setor de serviços, como é o caso do Metrô de São Paulo.

$\mathrm{O}$ organismo humano é dotado de um ritmo que regula os períodos de repouso e atividade (ritmos circadianos) que se repete a cada 24 horas. $\mathrm{O}$ trabalho em regime de turnos alternados, uma vez que constantemente são mudados os períodos de repouso e atividade, desregula este ritmo. Vários estudos enfocando a saúde de trabalhadores submetidos a este regime de trabalho apontam como distúrbios da saúde aqueles

379 “Art. $1 .^{\circ} \mathrm{O}$ regime de trabalho regulado nesta lei é aplicável aos empregados que prestam serviços em atividades de exploração, perfuração, produção e refinação de petróleo, bem como na industrialização do xisto, na indústria petroquímica e no transporte de petróleo e seus derivados por meio de dutos.

Art. $2 .^{\circ}$ Sempre que for imprescindível à continuidade operacional, o empregado será mantido em seu posto de trabalho em regime de revezamento.

$\S 1 .^{\circ} \mathrm{O}$ regime de revezamento em turno de 8 (oito) horas será adotado nas atividades previstas no art. $1 .^{\circ}$, ficando a utilização do turno de 12 (doze) horas restrita às seguintes situações especiais:

a) atividades de exploração, perfuração, produção e transferência de petróleo do mar;

b) atividades de exploração, perfuração e produção de petróleo em áreas terrestres distantes ou de difícil acesso." 
relacionados ao sono e ao funcionamento do aparelho digestivo, tendo sido evidenciada, também, a fadiga patológica, caracterizada por um cansaço crônico não recuperável com o período de repouso. Aliada à mesma, o trabalhador vivencia dificuldades de memorização, raciocínio e atenção, exigindo-se, por esta razão, maior esforço para a realização de qualquer atividade que venha a desenvolver. Neste contexto, o risco de acidentes aumenta, como conclui a pesquisa sobre saúde recentemente feita pelo Diesat e o Sindicato dos Metroviários de São Paulo.

Ao lado dos problemas acima referidos, aparecem também as limitações de tempo para o convívio familiar e social e envolvimento em atividades de lazer. $[\ldots]^{380}$

Portanto, o trabalho em turnos ininterruptos de revezamento é prejudicial ao trabalhador, não apenas pelos malefícios que causa ao regular funcionamento do chamado "relógio biológico", mas também pelas privações de ordem social da manutenção de uma rotina familiar, justificando-se plenamente a redução da jornada ao limite de seis horas diárias, conforme determina a Constituição Federal.

Uma questão objeto de polêmica e de certa hesitação jurisprudencial foi se a concessão de intervalos para descanso e repouso semanal descaracterizaria o turno ininterrupto de revezamento.

Ao sustentar que as pausas intrajornada e os descansos semanais não descaracterizam o "turno ininterrupto de revezamento", declarou Sebastião Geraldo de Oliveira:

“[...] as agressões aos ritmos circadianos, os desajustamentos familiares e sociais continuam, concedendo-se ou não intervalo ou repouso semanal. Não pode o intérprete se ater exclusivamente ao critério literal, ignorando a teleologia da norma. Ademais, o benefício da jornada reduzida não conflita nem exclui o direito aos intervalos para refeição e descanso e ao repouso semanal remunerado.[... $]^{381}$

${ }^{380}$ REBOUÇAS, Antonio José de Arruda et al. Insalubridade: morte lenta no trabalho: a insalubridade no Brasil. São Paulo: Oboré, 1989. p. 37-38.

${ }^{381}$ OLIVEIRA, Sebastião Geraldo de. Proteção jurídica à saúde do trabalhador. 5. ed. São Paulo: LTr, 2010. p. 163. 
Tal questão já se encontra pacificada pela jurisprudência, conforme entendimento consubstanciado na Súmula 360 do Colendo TST. ${ }^{382}$

Nesse sentido é o posicionamento do Tribunal Regional do Trabalho (TRT) da 2. ${ }^{\text {a }}$ Região, que registra, inclusive, que o cumprimento desse tipo de jornada configura "trabalho mais penoso":

Horas extras - turno ininterrupto de revezamento

Não prosperam também as alegações da ré. A existência de repouso semanal não afasta a incidência da jornada especial de seis horas prevista no artigo $7 .^{\circ}$, XIV da Constituição Federal. Neste sentido, aliás, o posicionamento do TST na OJ 360 de sua SDI-I.

Anote-se que a regra visa compensar o trabalho mais penoso dos que se alternam em horários distintos sem a fixação de um turno, isto é, de uma fração do horário de trabalho. Tal sistema de revezamento traz prejuízos à saúde do trabalhador, pois este não se ajusta a uma rotina, ao contrário, interfere no seu ritmo circadiano, já que permanecem os trabalhadores alternando-se no trabalho diurno, vespertino e noturno. É circunstância que além de impor desgaste físico pela variação periódica da jornada laboral, dificulta o convívio familiar e social e ainda impede que o trabalhador se dedique, por exemplo, a uma atividade acadêmica, se assim o desejar.

De se observar, por fim, que a ressalva feita no referido dispositivo constitucional é apenas em relação à negociação coletiva.

Neste contexto, nego provimento aos recursos (TRT 2. ${ }^{a}$ R., Acórdão 20110083754, Rel. Maria Inês Moura Santos Alves da Cunha, publ. 22.02.2011 - grifo nosso).

Outro aspecto que deve ser apreciado é o da alternância de turnos que abranjam, no todo ou em parte, horários diurnos e noturnos. Sebastião Geraldo de Oliveira ressalta que a jornada reduzida de seis horas deve ser mantida, ainda que sejam somente dois turnos de trabalho, visto que a mudança semanal interfere no ritmo circadiano, alterando constantemente o horário do sono. Nesse sentido, também a jurisprudência já sedimentou o entendimento, por meio da Orientação Jurisprudencial 360 da SDI-1 do Colendo TST. Importa a atividade desenvolvida pelo empregado, e não a da empresa:

382 Turnos ininterruptos de revezamento. Intervalos intrajornada e semanal (Res. 79/1997, DJ 13.01.1998).

A interrupção do trabalho destinada a repouso e alimentação, dentro de cada turno, ou o intervalo para repouso semanal, não descaracteriza o turno de revezamento com jornada de 6 (seis) horas previsto no art. $7^{\circ}, \mathrm{XIV}$, da $\mathrm{CF} / 1988$. 
Turno ininterrupto de revezamento. Dois turnos. Horário diurno e noturno. Caracterização (DJ 14.03.2008).

Faz jus à jornada especial prevista no art. 7. ${ }^{\circ}, \mathrm{XIV}$, da $\mathrm{CF} / 1988$ o trabalhador que exerce suas atividades em sistema de alternância de turnos, ainda que em dois turnos de trabalho, que compreendam, no todo ou em parte, o horário diurno e o noturno, pois submetido à alternância de horário prejudicial à saúde, sendo irrelevante que a atividade da empresa se desenvolva de forma ininterrupta.

Nessa esteira já ensinava Francisco Antônio de Oliveira, quando ainda estava instalada a polêmica acerca da concessão do intervalo para refeição e descanso, se esta descaracterizaria o turno ininterrupto de revezamento, afirmando que o trabalho realizado sob esse regime é penoso:

Dispôs a Constituição (art. 7. ${ }^{\circ}, \mathrm{XIV}$ ) que para o trabalho realizado em turnos ininterruptos de revezamento, a jornada será de seis horas.

A matéria imediatamente ganhou adeptos e se localizou em duas vertentes: a primeira, defendendo o ponto de vista de que se o trabalhador tiver intervalo para café ou para refeição não haveria falar em turno ininterrupto, já que os intervalos interrompem; a segunda, à qual nos filiamos, que argumenta no sentido de que o simples intervalo para café ou refeição ou mesmo descanso, por se constituir em exigência legal, em nada modifica a situação. Isso significaria que para a primeira corrente, só haveria turnos ininterruptos se o empregador viesse a descumprir a lei, vale dizer, se não concedesse intervalo algum [...].

A proteção daqueles empregados que laboram em turnos ininterruptos, tem escopo acentuadamente biológico e social. O empregado que a cada semana labora em turno diferente acaba por desregular o relógio biológico com sérios transtornos para a sua higidez. $\mathbf{O}$ trabalho assim realizado é penoso e submete o obreiro a uma pressão para a qual, pelo menos de início, não está preparado. E certamente tão cedo não conseguirá trocar a noite pelo dia, o dia pela noite e a tarde pela manhã ou pela noite.

Os turnos ininterruptos certamente o afastarão da convivência de seus familiares e do seu círculo social, posto que quando não estiver trabalhando estará dormindo ou, pelo menos, descansando, se é que conseguirá dormir. De resto, o que poderá descaracterizar o turno ininterrupto é a ausência de um dos turnos, não o intervalo durante a jornada. $^{383}$

Sebastião Geraldo de Oliveira comenta que muitas empresas, para fugirem da jornada reduzida de seis horas, estão alterando o trabalho para turno fixo, com jornada de

${ }^{383}$ OLIVEIRA, Francisco Antônio de. Direito do trabalho. São Paulo: RT, 1993. p. 276-277. 
oito horas, principalmente após a consolidação do entendimento pelo TST de que a negociação coletiva nesse sentido é válida, conforme a Súmula 423.

Diz esse autor que é falsa a ideia de que a fixação do turno é suficiente para afastar as agressões ao ritmo circadiano, acrescentando que especialistas indicam que revezamentos mais frequentes são menos danosos que um longo período de turnos noturnos. $^{384}$

Uma forma de amenizar a nocividade seria a proibição de horas extras e a extensão da jornada de seis horas para o trabalhador que cumpre jornada noturna. Ocorre que, ainda que possível tal controle, é comum encontrarmos o cumprimento de turnos ininterruptos de revezamento em atividades cuja natureza é intrinsecamente agressiva, por exemplo, o trabalho em aciaria, junto ao alto-forno. Para se ter uma ideia do calor nesse ambiente de trabalho, a temperatura atinge quase $1.600^{\circ} \mathrm{C}$ (aproximadamente $2.900^{\circ} \mathrm{F}$ ) no centro do alto-forno e o fogo consome cinco toneladas de ar. ${ }^{385}$

Observe-se que sempre há uma conjugação de fatores na atividade laboral, que podem torná-la mais agressiva e até mesmo penosa, e o trabalho em turno ininterrupto de revezamento é um deles.

\subsubsection{Garis ou coletores de lixo}

Como visto no tópico anterior, em que se buscou conceituar o "trabalho penoso", mencionou-se que é aquele relacionado à exaustão, ao incômodo, à dor, ao desgaste e à imutabilidade das tarefas desempenhadas que aniquilam o interesse, que leva o trabalhador ao exaurimento de suas energias. Algumas atividades foram arroladas como penosas, de acordo com lição de Leny Sato, como aquelas em que há esforço físico intenso no levantamento, transporte, movimentação, carga e descarga de objetos, materiais, produtos e

\footnotetext{
${ }^{384}$ OLIVEIRA, Sebastião Geraldo de. Proteção jurídica à saúde do trabalhador. 5. ed. São Paulo: LTr, 2010. p. 164-165.

${ }^{385}$ Disponível em: <http://ciencia.hsw.uol.com.br/ferro-e-o-aco3.htm>. Acesso em: 11 dez. 2012.
} 
peças; posturas incômodas, viciosas e fatigantes; e, dentre outras, aquelas atividades em que há contato direto com substâncias, objetos ou situações repugnantes [...]. ${ }^{386}$

Christiani Marques alerta que as atividades penosas, conforme o conceito apresentado, não equivalem às hipóteses de insalubridade e de penosidade. No entanto, nada impede que uma mesma atividade laboral possa ter característica penosa e perigosa; penosa e insalubre; ou tão somente penosa. ${ }^{387}$

Pode-se afirmar que os garis ou os trabalhadores que realizam a coleta do lixo desempenham suas atividades com constante esforço físico, com postura incômoda e fatigante, pois durante toda a sua jornada laboral recolhem o lixo, carregam os sacos com os dejetos e correm atrás do caminhão, permanecendo em pé, em um equilíbrio arriscado na traseira do caminhão de lixo. Além disso, têm contato constante com objetos repugnantes, com odor repulsivo, bem como com objetos cortantes e agentes insalubres. Portanto, a atividade pode ser considerada penosa e insalubre.

A respeito dos garis ou coletores de lixo, no dia 14.06.2011 foi apresentado o Projeto de Lei 1.590/2011, que acrescenta a Seção XIII-A ao Capítulo I do Título III da CLT, aprovada pelo Decreto-lei 5.452, de $1 .^{\circ}$ de maio de 1943, para dispor sobre jornada especial de trabalho para os coletores de lixo. Tal propositura não procura definir tal atividade como penosa; limita-se a dispor sobre a redução da jornada para os encarregados da coleta do lixo, bem como para os motoristas responsáveis pela condução do veículo coletor de lixo.

No entanto, convém transcrever parte da justificativa desse Projeto de Lei, que destaca, inclusive, o paradoxo existente entre a preocupação com o meio ambiente, no caso, a destinação, a reciclagem do lixo e a invisibilidade do trabalhador:

O mundo contemporâneo se une, com consciência cada vez maior, em prol da necessidade de conservação do meio ambiente e dos desafios de serem encontrados os pontos de equilíbrio entre a preservação do planeta e as políticas de desenvolvimento econômico. A ideia de sustentabilidade, em prol da garantia de uma vida satisfatória para as

\footnotetext{
386 SATO, Leny. Conceito de trabalho penoso. Revista CIPA, São Paulo, v. 15, n. 179, p. 41, 1994.

${ }^{387}$ MARQUES, Christiani. A proteção ao trabalho penoso. São Paulo: LTr, 2007. p. 64.
} 
gerações futuras assume, pois, caráter diretivo nos debates e adquire relevância nas políticas governamentais.

Nesse contexto, o grave problema do lixo urbano ganha visibilidade pública e começa a ser tratado em suas várias dimensões - a produção, a coleta, o devido direcionamento, a reutilização e a reciclagem etc.

Fomenta-se a consciência dos cidadãos sobre a importância dessas questões, mas, paradoxalmente, o trabalhador que presta o serviço na coleta do lixo não tem o merecido reconhecimento da sociedade sobre a importância de sua atividade. Muito ao contrário: mesmo tratando-se de atividade de incontestável relevo e alcance social, especialmente nos grandes centros urbanos, o trabalhador desse segmento profissional é vítima de discriminação e preconceito social. [... $]^{388}$

\section{A justificativa do Projeto de Lei 1.590/2011 explicita a classificação do trabalho} em contato com o lixo urbano como atividade insalubre e transcreve estudo publicado no Caderno de Saúde Pública, em que tal atividade é considerada como "atividade de risco". 389

\footnotetext{
${ }^{388}$ Disponível em: <http://www.camara.gov.br>. Acesso em: 5 jul. 2011.

${ }^{389}$ Com efeito, o Ministério do Trabalho e Emprego classifica o trabalho em contato permanente com o lixo urbano (coleta e industrialização) como atividade insalubre, em grau máximo (Norma Regulamentadora n. ${ }^{\circ}$ 15, anexo 14, da Portaria n. ${ }^{\circ} 3.214 / 1978$ do Ministério do Trabalho e Emprego).
}

Estudos científicos também denunciam a atividade como de risco para a saúde do trabalhador, a exemplo da significativa pesquisa descrita em artigo publicado no Cadernos de Saúde Pública, Rio de Janeiro, v. 13, n. 4, a seguir:

"Os trabalhadores, por realizarem suas atividades ao ar livre, ficam expostos ao calor, ao frio, à chuva e, ainda, às variações bruscas de temperatura. Durante o processo de trabalho, o compactador de lixo é acionado frequentemente, ocasionando ruído que se soma aos ruídos produzidos no trânsito e nas ruas.

As atividades de coleta são realizadas nos morros e em ruas de asfalto precário, portanto os trabalhadores ficam sujeitos a trepidação pelo fato de viajarem no estribo do veículo coletor. Durante o recolhimento do lixo, os coletores sobem e descem ladeiras, percorrendo quilômetros a pé. Além disso, os horários de coleta muitas vezes coincidem com o de tráfego intenso, possibilitando acidentes como atropelamentos e colisões. [...]

Algumas dessas operações são realizadas por todos os trabalhadores. O transporte e manuseio do lixo residencial de habitações coletivas ou individuais (latão e sacola) são as mais frequentes (20,5\% do tempo cada) e constituem-se em atividades de risco na medida em que o lixo não é acondicionado adequadamente. As consequências para o trabalhador são usualmente descritas como cortes e/ou ferimentos ocasionados pela presença de objetos perfurocortantes. Na operação característica da favela, os resíduos são coletados com peneira devido à falta de embalagens dos mesmos, o que necessariamente implica varredura complementar. Isto expõe o trabalhador a agentes químicos e biológicos derivados da poeira. Frequentemente, recipientes de lixo servem de criadouros para vetores de doenças infectocontagiosas, definindo risco biológico importante. Além disso, é evidente nessa atividade a existência de esforços físicos e posições inadequadas repetitivas.

As operações de coleta de lixo nas indústrias, no comércio e no presídio envolvem atividades que requerem grande esforço físico. Estas operações de coleta de lixo envolvem o levantamento e transporte de latões de 200 l, latas de 501 a 100 l, caçambas de 1.050 l, demandando dos trabalhadores esforço físico 
E um dos autores mencionados no projeto de lei, Luiz Antonio dos Anjos é autor, com João Alberto Ferreira, de estudo sobre a avaliação da carga fisiológica de trabalho na coleta de lixo domiciliar, apontando para a impropriedade da legislação em vigor e qualificando o trabalho na coleta de lixo como "pesado":

[...] Apesar da sua aplicação inequívoca na inter-relação saúde/doença da população trabalhadora, a investigação da carga fisiológica de trabalho é feita de forma muito superficial no Brasil, havendo necessidade de estudos que possibilitem o conhecimento do GE das atividades laborais, a fim de fazer com que a legislação leve em conta as características individuais e a repercussão sobre a saúde do trabalhador.

A coleta de lixo domiciliar, durante a qual o trabalhador anda, corre, sobe e desce ladeiras, pega pesos diferenciados o tempo todo (Ferreira, 1997) e está submetido a tensões permanentes pela presença constante de fluxo de outros veículos nas ruas (Velloso, 1995), representa um bom exemplo da necessidade de avaliação da carga de trabalho, por ser uma atividade aparentemente extenuante (Robassi et al., 1992), com

intenso. Por esse motivo, aqueles com peso maior que 2001 , por norma da empresa, devem ser compartilhados por colegas da guarnição.

O compactador de lixo localizado na parte traseira do veículo coletor, que é acionado pelo próprio trabalhador durante a coleta de lixo, pode ocasionar prensagem dos membros superiores de outro trabalhador, enquanto esse desempenha suas atividades. Pôde-se observar que, como o veículo coletor é alto, existe o risco de esbarrar nos fios de eletricidade que se encontram em seu trajeto, especialmente nas ladeiras.

O principal risco social relacionado a este processo de trabalho é a falta de treinamento adequado dos trabalhadores, o que os torna impotentes para reivindicar medidas preventivas contra acidentes, doenças infectocontagiosas e melhores condições de trabalho.

Cabe ressaltar que os riscos mencionados não agem sobre o trabalhador de forma isolada. Assim, o corpo do trabalhador interage com os diversos riscos existentes, podendo adoecer e sofrer acidentes. [...]

O processo de trabalho, além de ser constituído por diferentes operações, é desorganizado. O trabalhador, apesar de realizar tarefas que demandam esforço físico na presença de ruídos e em ritmo acelerado, não possui pausas oficializadas para descanso. Além disso, esse profissional está exposto a seis tipos de fatores de risco (físicos, químicos, mecânicos, ergonômicos, biológicos e sociais). Entre estes riscos observados destacam-se: atropelamento, queda grave, cortes, ferimentos, esforço excessivo, ruído, gases tóxicos (monóxido de carbono), contato com agentes biológicos patogênicos e falta de treinamento para o serviço, conscientizando o coletor de lixo sobre os riscos aos quais fica sujeito durante a realização de suas tarefas.

Alguns autores identificam como prejudiciais à saúde dos coletores de lixo dois dos fatores observados neste estudo: o excesso de esforço físico (Kemper et al., 1990) e o excesso de ruído (Kessler et al., 1987; Betancourt, 1993)" (VELlOSO, Marta Pimenta; SANTOS, Elizabeth Moreira dos; ANJOS, Luiz Antonio dos. Processo de trabalho e acidentes de trabalho em coletores de lixo domiciliar na cidade do Rio de Janeiro, Brasil. Disponível em: $<$ http://www.scielosp.org/scielo.php?pid=S0102311X1997000400012\&script=sci_arttext $>$. Acesso em: 6 jun. 2011). 
repercussões importantes na saúde dos trabalhadores envolvidos (Mamtani \& Cimino, 1992; Velloso et al., 1997).

Este artigo relata os resultados de uma pesquisa sobre a avaliação do gasto energético e da carga fisiológica de trabalho numa amostra probabilística de coletores de lixo domiciliar da Companhia Municipal de Limpeza Urbana do Rio de Janeiro (COMLURB), demonstrando a impropriedade da legislação vigente no que diz respeito à classificação do trabalho do ponto de vista fisiológico. [...]

Comparativamente, a classificação do trabalho de coleta de lixo domiciliar da presente amostra de garis segundo a legislação brasileira colocaria essa atividade como moderada [...]. Entretanto, empregando qualquer outra das classificações tipicamente utilizadas na literatura científica, o trabalho de coleta de lixo domiciliar seria, indubitavelmente, considerado pesado. Essa diferença pode ser explicada pelo fato de a legislação utilizar uma tabela fixa de valores de gasto energético para todos os trabalhadores, independentemente do gênero, idade, características antropométricas, estado nutricional e nível de aptidão física. Na verdade, não há condicionantes para os valores apresentados na legislação e nenhuma citação sobre sua origem. [...]

\section{Conclusão}

Os resultados da taxa de metabolismo encontrados para os trabalhadores da coleta de lixo no Município do Rio de Janeiro, tomando-se como referência a legislação vigente, indicam a realização de trabalho moderado. Todavia, avaliação mais criteriosa, individualizada, mostra que a maior parte dos trabalhadores estava realizando trabalho pesado, realçando o risco de se utilizarem valores médios para questões de saúde do trabalhador. Adequar a legislação brasileira, de forma a considerar a individualidade do trabalhador, pode parecer uma proposta que implique elevação de custos na avaliação da atividade laboral. Entretanto, a utilização da NR-15 (Brasil, 1978a) atual, ou seja, a não incorporação das características individuais dos trabalhadores, pode levar ao desgaste prematuro de muitos destes, com repercussão importante na sua qualidade e quantidade de vida, além de sobrecarga no sistema público de saúde. ${ }^{390}$

Ressalte-se, assim, que o gari ou coletor de lixo está exposto a seis tipos de fatores de risco (físicos, químicos, mecânicos, ergonômicos, biológicos e sociais). Entre estes riscos observados destacam-se: atropelamento, queda grave, cortes, ferimentos, esforço excessivo, ruído, gases tóxicos (monóxido de carbono), contato com agentes biológicos patogênicos e exposição ao risco de mordeduras de animais, como se vê no seguinte estudo:

${ }^{390}$ ANJOS, Luiz Antonio dos; FERREIRA, João Alberto. A avaliação da carga fisiológica de trabalho na legislação brasileira deve ser revista! O caso da coleta de lixo domiciliar no Rio de Janeiro. In Cad. Saúde Pública v.16 n.3 Rio de Janeiro jul./set. 2000. Disponível em: <http://www.scielosp.org/scielo. php?script=sci_arttext\&pid=S0102-11X2000000300026\&lng=pt\&nrm=isso $>$. Acesso em: 5 jul. 2011. 
[...] A medida que a população aumenta, no entanto, a tarefa de recolher o lixo torna-se complexa, pois maior quantidade de detritos são produzidos; além disso é considerada atividade insalubre em grau máximo, devido ao contato dos trabalhadores com agentes biológicos, presentes nos lixos recolhidos, conforme consta na Norma Regulamentadora n. ${ }^{\circ}$ 15, anexo 14 (Segurança..., 1995).

Percebe-se então que os garis estão sujeitos ao contato íntimo com estes resíduos. Como realizam seu trabalho a "céu aberto" (em praças, ruas e demais logradouros), encontram-se submetidos às radiações solares, à umidades ou climas secos, ao trânsito existente no horário de trabalho, à mordedura de animais soltos nas ruas, às variações de temperatura, entre outros tipos de agentes agressores. Wingaarden \& Smith (1988) referem a existência do calor como risco ocupacional porque pode agravar ou causar o aparecimento de doenças renais, cardíacas e respiratórias. [...]

Estas condições de trabalho podem lhes favorecer a ocorrência de acidentes de trabalho e doenças, que possivelmente resultarão em prejuízos à sua saúde física e mental. ${ }^{391}$

Diante disso, de acordo com as características anteriormente expostas, mormente pelo esforço físico intenso, agregado aos vários fatores de risco, o trabalho de coleta de lixo deve ser considerado como penoso.

\subsubsection{Trabalho nas carvoarias}

Um exemplo que mais expressa a degradação social imposta aos trabalhadores dáse nas carvoarias. Para exame dessa complexa realidade social, é preciso enfocar uma face não muito conhecida da cadeia produtiva do aço: a que explora mão de obra escrava na produção de carvão para as siderúrgicas que exportam ferro-gusa. É o retrato da interação, em uma economia globalizada, de diferentes formas de produção em uma mesma cadeia produtiva, o arcaico na produção do carvão e o moderno na produção do aço.

Para produzir ferro-gusa é preciso utilizar principalmente carvão e minério de ferro. De acordo com o Instituto Observatório Social, formado por centrais sindicais e pelo Departamento Intersindical de Estatística e Estudos Socioeconômicos (Dieese), o gusa alimenta um mercado de alta tecnologia, o dos aços especiais. A produção, contudo, tem na

${ }^{391}$ SILVEIRA, Edilene Aparecida Araújo da; ROBAZZI, Maria Lúcia do Carmo Cruz; LUÍS, Margarita Antonia Villar. Varredores de rua: acidentes de trabalho ocorridos na cidade de Ribeirão Preto, Estado de São Paulo, Brasil. Rev. Latino-Americana de Enfermagem, Ribeirão Preto, v. 6, n. 1, p. 71-79, jan. 1998. 
base de sua cadeia de valor uma das piores formas de exploração humana: o trabalho escravo, que acontece em carvoarias localizadas na floresta amazônica.

Acrescente-se que em demais localidades do nosso país foi constatada a existência de carvoarias com exploração de mão de obra escrava, como no Mato Grosso, graças à fiscalização exercida pelo Grupo Móvel, constituído por auditores fiscais do Ministério do Trabalho e Emprego, membros da Polícia Federal (delegados e agentes) e de membros do Ministério Público do Trabalho. As denúncias normalmente são feitas pela Comissão Pastoral da Terra ou diretamente pelo Ministério do Trabalho e Emprego.

O Instituto Observatório Social é responsável por uma publicação especial sobre trabalho escravo no Brasil, em que consta:

A Amazônia brasileira produz o melhor ferro-gusa do mundo, usado principalmente na produção de peças automotivas. É um mercado que movimenta 400 milhões de dólares anuais somente na região Norte $-2,2$ milhões de toneladas/ano - e tem como principal compradora a indústria siderúrgica dos Estados Unidos. Esse gusa alimenta um mercado de alta tecnologia, o dos aços especiais. [...]

O principal comprador do ferro gusa que tem na sua cadeia de produção o trabalho escravo é a Nucor Corporation, maior produtora de aço dos Estados Unidos. Essa corporação usa o ferro-gusa para produzir insumos que abastecem a maioria das indústrias automotivas americanas. Carros norte-americanos, de diversas marcas, saem da linha de produção montados com aços especiais que tiveram trabalhadores escravizados no primeiro elo da cadeia produtiva. [...]

\section{Reincidência}

O uso de trabalho escravo envolvendo siderúrgicas não é recente. Em 1995, ano em que o Ministério do Trabalho criou o Grupo Especial de Fiscalização Móvel, quatro siderúrgicas localizadas no Mato Grosso e em Minas Gerais foram acusadas de manter trabalhadores escravos em carvoarias. No Mato Grosso, a pequena cidade de Ribas do Rio Pardo se tornou uma espécie de polo escravagista, com denúncias em vários setores da economia.

No ano seguinte surgiram pela primeira vez, nos relatórios do Grupo Móvel, os nomes de siderúrgicas ligadas a grandes conglomerados econômicos. É o caso da siderúrgica Pindaré, da Queiroz Galvão, com sede em Açailândia (MA). Ela aparece em relatórios do Grupo Móvel em 1996, 1997, 1998, 2002 e 2003. A Simasa, também da Queiroz Galvão, aparece pela primeira vez em 2002, tornando-se frequente desde então. A Margusa, comprada pela Gerdau no dia 2 de dezembro de 2003, aparece em março de 2004. [...] $]^{392}$

${ }^{392}$ Trabalho escravo no Brasil. Observatório Social em Revista, n. 6, p. 12, jun. 2004. 
Mesmo nas carvoarias onde não existe trabalho escravo, a legislação é sistematicamente descumprida. Os trabalhadores não recebem equipamentos de proteção individual (EPIs), não têm alojamento nem assistência médica, não são registrados em carteira tampouco têm direito aos benefícios legais.

Como consta do sítio do Observatório Social, em um relatório de inspeção realizada em carvoarias ligadas à Simasa e à Margusa, empresas acima mencionadas, o Procurador do Trabalho Luercy Lino Lopes, além de apontar o envolvimento direto das siderúrgicas com o trabalho escravo, acrescentou:

Raramente algum trabalhador é flagrado de posse de EPI (equipamento de proteção individual); trabalham em meio à fuligem e fumaça de carvão, sem camisa ou com a camisa toda rasgada e suja; com calção e sem botinas e luvas. Em nenhuma das carvoarias vistoriadas foi encontrada água potável. ${ }^{393}$

A fiscalização do Grupo Móvel em diversas ocasiões constata a existência de trabalhadores submetidos a péssimas condições, que não caracterizam trabalho escravo, mas "trabalho degradante": além das condições acima descritas, o trabalhador muitas vezes dorme em um curral sem paredes, não tem acesso a água potável ou a assistência médica, fica sem o pagamento de férias, $13 .^{\circ}$ salário, e em quase $100 \%$ dos casos não conta com um banheiro no local de trabalho.

As práticas que conduzem a essa trágica realidade social vêm sendo combatidas pelo Poder Executivo e pelo Ministério Público do Trabalho, como relatado. Há também iniciativa do Legislativo, que estabelece regras para o ambiente de trabalho em carvoarias.

O Projeto de Lei 3.480/2004 estabelece que o terreno, destinado aos fornos de carvão vegetal, considerado área de proteção, deverá ser cercado e sinalizado. O objetivo é evitar que pessoas que não trabalhem na produção entrem nas áreas de fornos, em um raio inferior a cinquenta metros. No caso dos trabalhadores e pessoas autorizadas, o acesso às áreas de produção só poderá ser feito mediante uso de equipamento de proteção individual.

${ }^{393}$ Disponível em: <http://www.observatoriosocial.org.br/destaque/escrav/escrav03.htm>. Acesso em: 5 jul. 2011. 
Deverão estar disponíveis na área de proteção: água potável; caixa de primeiros socorros sob a supervisão de pessoa treinada; e guarita para abrigo e repouso dos trabalhadores. Os empregados terão direito a moradia com condições mínimas de saúde e segurança, no mínimo a quinhentos metros de distância dos fornos. O projeto também pró́be a terceirização dos serviços diretamente relacionados à produção de carvão vegetal.

A autora do projeto de lei, Deputada Ann Pontes, argumenta que o trabalho nas carvoarias compromete a saúde de homens, mulheres e crianças, ao submetê-los "a uma atividade pesada e desgastante, sob altas temperaturas e dentro de uma espessa nuvem de fumaça”. Além disso, ela lembra que graves acidentes têm atingido as famílias dos carvoeiros, que, "por conveniência dos empregadores, residem, em condições desumanas, ao lado dos fornos". A propositura encontra-se arquivada junto à Mesa Diretora da Câmara dos Deputados. ${ }^{394}$

Ainda que não existissem ilegalidades praticadas na exploração da mão de obra que labora nas carvoarias, ainda que todos os trabalhadores fossem empregados regularmente contratados e percebessem corretamente as verbas devidas de acordo com a legislação trabalhista em vigor, as condições de trabalho na produção de carvão vegetal são de tal forma agressivas e extenuantes que forçosamente este tipo de trabalho deve ser considerado penoso.

Estudo realizado por pesquisadores da Universidade Federal do Mato Grosso teve por finalidade avaliar os riscos físicos e ergonômicos durante a fase de abastecimento e da retirada dos fornos, nos quais são produzidos os carvões; levou em consideração que os trabalhadores exercem suas atividades a céu aberto e expostos ao calor do forno; e, por meio de uma avaliação quantitativa, bem como no tocante aos usos dos equipamentos de proteção individual e quanto aos riscos aos quais os trabalhadores estão submetidos, objetivou proporcionar condições de melhoria e adequada qualidade de vida e saúde aos trabalhadores.

A análise efetuada pelos pesquisadores foi a seguinte:

${ }^{394}$ Disponível em: <www.camara.gov.br>. Acesso em: 6 jul. 2011. 
Observa-se que a carvoaria está instalada em local plano, depara-se com a fileira de fornos envolvidos pela fumaça, cujo cheiro forte faz arder os olhos e impregna tudo e todos ao redor.

Pilhas de resíduos de madeira esperam a vez de ir para o forno e montes de carvão, às vezes, ainda fumegantes, pelo ensacamento. Os trabalhadores, geralmente seminus, têm o corpo coberto pela fuligem e deles, muitas vezes, somente se veem os olhos e os dentes.

A maneira pela quais os carvoeiros organizam o trabalho é variável: individual e solitário, ou em duplas. As principais funções no processo são as de forneiro-carvoeiro e de carbonizador-barrelador.

As peças de madeira que estão estocadas na parte externa do forno são transportadas manualmente e deixadas perto da abertura ou "boca" do forno. Uma vez preenchida a abertura do forno, recomeça o transporte manual da madeira para o interior do mesmo. Dessa forma, o trabalhador transporta a mesma peça de madeira duas vezes. A produtividade do forno depende do processo de enchimento. Se a carga é mal feita, a produção será menor do que a capacidade do forno, acarretando prejuízo. [...]

O empilhamento prossegue até uma altura tal que permite apenas a passagem do trabalhador da área externa para o interior do forno. [...] A operação de abastecimento do forno apresenta exigências físicas e cognitivas para o trabalhador. As exigências físicas decorrem das condições de trabalho e do esforço muscular despendido.

Os deslocamentos são numerosos e exigem movimentos coordenados dos membros superiores e inferiores; posturas penosas, com torção e flexão do tronco; movimentos repetitivos e uso de força para o transporte manual da carga. É importante destacar que o esforço físico se dá em condições de desconforto térmico. [...]

A queima ou combustão da madeira dura geralmente três dias. Durante o cozimento da madeira, o carbonizador supervisiona o processo, no mínimo de hora em hora. Através da liberação e oclusão dos orifícios do forno, controla a entrada de oxigênio e dessa forma, a intensidade da combustão. Segundo os trabalhadores, esta operação é importante para garantir a qualidade do carvão.

Consideram índices e parâmetros construídos na prática, como a cor e o volume de fumaça que sai pelos orifícios do forno. A fumaça de cor azul indica a conclusão do processo de cozimento da madeira. O principal cuidado do carbonizador é impedir que o forno produza um superaquecimento capaz de provocar a ruptura da cinta que sustenta a abóbada do forno, fazendo desmoronar toda a estrutura, com perda do produto ou carga.

A repetitividade da tarefa e as condições climáticas e de conforto desfavoráveis contribuem para a penosidade. [...]

A análise da atividade mostra que a retirada do carvão é a fase mais crítica no que se refere à exposição a altas temperaturas e aos gases originados na combustão da madeira, sob exigência de esforços físicos importantes. Estão presentes riscos de acidentes como queimaduras. Em algumas situações, dependendo da urgência do pedido, o carvão é retirado ainda aquecido, aumentando a sobrecarga térmica e o risco de queimadura corporal. O calor emitido para o meio ambiente de trabalho pelos fornos, no processo de carbonização da madeira, interage com o 
calor natural e o calor corporal interno, levam ao aumento do metabolismo corporal e, como decorrência, ao aumento da produção interna de calor, explicando a intensa sudorese observada nos trabalhadores. Gripes e resfriados são frequentes nos trabalhadores devido à exposição às diferenças de temperatura: elevada, próximo aos fornos, e baixa, no ambiente. A etapa de resfriamento do carvão exige um controle atento porque este pode entrar em combustão espontânea, causando a perda do produto. ${ }^{395}$

Dessa forma, esse estudo revelou as condições adversas às quais se submetem os trabalhadores que lidam na produção de carvão vegetal, nas carvoarias dos rincões deste país. Constatou essa pesquisa, assim como fiscalizações do Ministério do Trabalho e Emprego têm constatado, que esse tipo de trabalho exige grande esforço físico, há exposição à radiação solar excessiva, ao calor emitido pelos fornos, à fumaça expelida com a combustão da madeira, que irrita os olhos e as vias aéreas superiores. Além disso, os trabalhadores estão sujeitos às picadas de animais peçonhentos.

Todos esses fatores concomitantes levam à conclusão de que o trabalho de produção de carvão vegetal nas carvoarias é penoso.

As medidas cabíveis, à luz do preceito constitucional, são voltadas à redução dos riscos inerentes ao trabalho, por meio de normas de saúde, higiene e segurança, conforme prevê o inciso XXII do artigo $7 .^{\circ}$ da Constituição Federal. Demais alternativas podem ser viáveis e desejáveis, como a redução da jornada.

Os meios mais adequados para prevenção dos riscos, para evitar os danos, serão examinados no próximo capítulo.

Importante frisar, neste ponto, que nem sempre é possível eliminar todos os riscos, e danos podem ocorrer. Neste caso, há legislação em vigor que dispõe sobre reparação monetária de alguns riscos, com exceção da exposição ao trabalho penoso, como já dito. Há previsão no ordenamento jurídico de responsabilização do empregador, bem

${ }^{395}$ SILVA, Luciene Regina Pinheiro da; NOGUEIRA, Marta Cristina de Jesus Albuquerque; DURANTE, Luciane Cleonice; LAMBERT, José Antonio. Risco de exposição e a saúde do trabalhador em uma carvoaria no município de Sinop. Disponível em: <http://cpd1.ufmt.br/eest/index2.php? option=com_docman\&task=doc_view\&gid=112\&Itemid=99>. Acesso em: 6 jul. 2011. 
como de concessão de benefícios na esfera previdenciária, em caso de incapacidade do trabalhador, a cargo da Previdência Social, ou seja, do contribuinte brasileiro.

O presente estudo enfoca se tais previsões normativas são adequadas e suficientes para gerar qualidade de vida e saúde aos trabalhadores, e, em caso negativo, quais as alternativas juridicamente viáveis, que não redundem em mais ônus para os cofres públicos. 


\section{CAPÍTULO 4 FORMAS DE REPARAÇÃO}

\subsection{Perspectivas de reparação dos danos}

A preservação do meio ambiente nunca foi obstáculo que servisse de freio ao desenvolvimento industrial, desde a constituição do Estado Moderno. Ao revés, a industrialização sempre determinou a exploração dos recursos naturais e das matrizes energéticas. E se atualmente, diante da escassez de recursos naturais, extinção de ecossistemas e desmatamento florestal, a relação econômica não é somente determinada pelo binômio capital-lucro, passando a contar com a preocupação com a preservação, fazendo com que desenvolvimento não seja sinônimo de crescimento econômico e distribuição de renda, mas também de consumo consciente e sustentabilidade ambiental, o mesmo não se pode dizer no tocante aos recursos humanos, à exploração da força de trabalho humana, talvez por se reproduzir, não ser esgotável e ser de substituição barata.

No entanto, para que o discurso da preservação ambiental passe a se concretizar e a se tornar efetivo, mudanças significativas devem ser implementadas na cadeia de produção e nos padrões de consumo. Dessa forma, para que nosso país não somente esteja entre as grandes economias no ranking mundial, mas de fato seja uma democracia moderna, com menos desigualdades econômicas e menos tragédias sociais, dentre elas as doenças e os acidentes do trabalho, é preciso que haja um esforço voltado à conscientização, à mudança do comportamento econômico e produtivo, em que todos desempenham papéis para um novo padrão da vida em sociedade.

Nessa esteira, o Estado, como agente regulador da atividade econômica, tem papel fundamental na condução desse novo estágio do desenvolvimento. Importante lembrar que um dos objetivos fundamentais da República é a garantia do desenvolvimento nacional, no mesmo passo da construção de uma sociedade livre, justa e solidária, como prevê o artigo $3 .^{\circ}$ da Constituição Federal, respeitando o valor social do trabalho, conforme artigo $1 .^{\circ}$ da Carta. 
Com já dissemos em capítulo anterior, quando tratamos do trabalho e do meio ambiente de trabalho, o objeto tutelado é a vida e a saúde do trabalhador. E se para coibir as condutas e atividades lesivas ao meio ambiente existem sanções penais e administrativas, para a tutela do meio ambiente de trabalho há normas de caráter sanitário, trabalhista. Cabe observar que o Direito Penal é um ramo que nunca teve muita preocupação na defesa dos trabalhadores, ao contrário, voltava-se mais à repressão às lutas em defesa de melhores condições de trabalho e à tipificação da greve como crime.

Contudo, alguns dispositivos na legislação penal merecem destaque por se relacionarem ao tema, principalmente o artigo 132 do Código Penal, que prevê:

Expor a vida ou a saúde de outrem a perigo direto e iminente:

Pena - detenção, de três meses a um ano, se o fato não constitui crime mais grave.

Parágrafo único. A pena é aumentada de um sexto a um terço se a exposição da vida ou da saúde de outrem a perigo decorre do transporte de pessoas para a prestação de serviços em estabelecimentos de qualquer natureza, em desacordo com as normas legais. (Incluído pela Lei ${ }^{\circ}{ }^{\circ}$ 9.777, de 29.12.1998.)

Lembra Guilherme Purvin de Figueiredo que a Lei 8.213, de 24 de julho de 1991, que dispõe sobre os Planos de Benefícios da Previdência Social, no seu artigo 19, § 2. , considera contravenção penal o não cumprimento de normas de segurança e higiene do trabalho, com cominação de pena de multa, só que não alcança as pessoas jurídicas.

Nesse sentido inovou a Lei 9.605, de 12 de fevereiro de 1998, que dispõe sobre as sanções penais e administrativas derivadas de condutas e atividades lesivas ao meio ambiente. Esse autor destaca dois dispositivos desse diploma, de imediata aplicabilidade na área do meio ambiente de trabalho: o artigo 54, que comina a pena de reclusão, de um a quatro anos, e multa, àquele que, dolosamente, "causar poluição de qualquer natureza em níveis tais que resultem ou possam resultar em danos à saúde humana, ou que provoquem a mortandade de animais ou a destruição significativa da flora”. A pena será de detenção de seis meses a um ano e multa, em caso de culpa. Observa o autor que o texto penal ora em vigor tem aplicabilidade mais adequada à tutela dos trabalhadores no seu meio ambiente de trabalho, pois prevê a modalidade culposa, o que não ocorre no texto da Lei de Política Nacional do Meio Ambiente (Lei 6.938/1981, com redação alterada pela Lei 7.804/1989). 
O segundo dispositivo aplicável, que também tem seu viés de proteção à saúde dos trabalhadores. é o artigo 60 da Lei 9.605/1998, que comina a pena de detenção de um a seis meses ou multa, ou ambas as penas, cumulativamente, a quem

[...] construir, reformar, ampliar, instalar ou fazer funcionar, em qualquer parte do território nacional, estabelecimentos, obras ou serviços potencialmente poluidores, sem licença ou autorização dos órgãos ambientais competentes, ou contrariando as normas legais $\mathrm{e}$ regulamentares pertinentes. ${ }^{396}$

Guilherme Purvin de Figueiredo destaca a importância da previsão da modalidade culposa na tutela penal do meio ambiente do trabalho, pois seria muito difícil a ocorrência de dolo nos casos de acidentes de trabalho e de doenças profissionais. Observa que na França a violação das normas concernentes à medicina do trabalho acarreta sanções penais diversas, ainda que tal país não se apresente como exemplo de avanço significativo na tutela do meio ambiente laboral. ${ }^{397}$

Em capítulo anterior, havíamos discorrido sobre o arcabouço normativo estatal de proteção ao direito à saúde no trabalho; e, nos dispositivos legais ora mencionados, o enfoque não é de reparação ao sinistrado, e sim de repressão aos agentes pelas práticas lesivas ao meio ambiente e meio ambiente do trabalho.

De toda forma, é forçoso reconhecer o avanço trazido no nosso país com a Lei 9.605/1998, diante da autorização da responsabilização da pessoa jurídica; a possibilidade de repressão na esfera penal, indubitavelmente, vem servir de freio para aqueles que não titubeiam em expor a vida dos trabalhadores aos riscos, na busca do lucro a qualquer custo.

O meio ambiente ecologicamente equilibrado é um bem jurídico, constitucionalmente protegido, ensina Cristiane Derani. Salienta essa autora:

Este bem não pode ser desmembrado em parcelas individuais. Seu desfrute é necessariamente comunitário e reverte ao bem-estar individual. Já se disse que o meio ambiente, enquanto bem jurídico, apresenta-se como garantia das condições básicas necessárias para a

\footnotetext{
${ }^{396}$ FIGUEIREDO, Guilherme José Purvin de. Direito ambiental e a saúde dos trabalhadores. São Paulo: LTr, 2007. p. 179.

${ }^{397}$ Idem, ibidem, p. 180.
} 
manutenção e desenvolvimento da vida em geral e da humana em particular; [...]. ${ }^{398}$

Por isso, nada mais justo que os responsáveis pelos danos ambientais ou os que se enriquecem à custa de um "patrimônio social", qualquer que seja ele, respondam efetivamente pelos danos não somente na esfera penal, como também por meio das demais formas de responsabilização, com a maior abrangência possível, à luz do princípio do poluidor-pagador.

Quando falamos em danos à saúde humana e à do trabalhador em particular, nos referimos aos acidentes do trabalho ou doenças ocupacionais, que no mais das vezes deixam sequelas incapacitantes ou até levam à morte. Em razão disso, os acidentados recebem benefícios, relativos à saúde, à previdência e assistência social, que em caso de óbito são direcionados aos beneficiários do trabalhador.

Nesse passo, toda a sociedade arca com os ônus decorrentes desses danos, na medida em que todos os contribuintes recolhem tributos para os cofres públicos; dessa forma, a sociedade participa do custeio dos benefícios. Neste ponto, nenhum reparo há a fazer, pois se trata da previsão constitucional de que o conjunto integrado de ações que compreende a seguridade social é de iniciativa dos Poderes Públicos e da sociedade, de modo a assegurar os benefícios, de acordo com os objetivos da universalidade da cobertura e do atendimento, entre outros, à luz do contido no artigo 194, parágrafo único e seus incisos, da Constituição Federal.

Ocorre que, enquanto parcela da sociedade polui, exige dos trabalhadores desempenho em condições extenuantes, inadequadas e de risco, e por isso provoca danos, outra parcela, ainda que maior, assume os dispêndios decorrentes de tais danos. Por este motivo é preciso buscar, nos preceitos constitucionais, nos princípios que norteiam nosso ordenamento jurídico e no arcabouço legal em vigor, formas de reparação desses danos, de maneira a diferenciar o "poluidor", o provocador dos sinistros, dos demais membros da sociedade. Uma forma de estabelecer tal diferenciação é com a aplicação das medidas repressivas, como ocorre com a cominação das sanções penais e administrativas, derivadas de condutas e atividades lesivas ao meio ambiente, como penas restritivas da liberdade ou

\footnotetext{
${ }^{398}$ DERANI, Cristiane. Direito ambiental econômico. São Paulo: Saraiva, 2008. p. 248.
} 
multas pecuniárias, ou ambas. Outro modo é a responsabilização civil do causador do dano, ou ainda de obrigação de fazer ou de pagamento de multa, impostas judicialmente ou em decorrência da atuação do Ministério Público, como veremos em tópico específico.

De toda forma, pensamos que todas as hipóteses aqui mencionadas não são suficientes para ressarcir o enorme custo social oriundo desses danos, especialmente em caso de morte do arrimo de família, que deixa mulher e filhos desassistidos, com consequências sociais trágicas. E, caso os instrumentos legais vigentes não sejam suficientes, cabe aos operadores do direito, à sociedade em geral, propor novas hipóteses legais, que efetivamente desestimulem a provocação do dano, sirvam de repressão ao agente causador, de reparação à vítima e de ressarcimento aos cofres públicos. E a aplicação dos princípios ambientais, sem dúvida, é um caminho certo a ser trilhado, na perspectiva da reparação dos danos não somente ao meio ambiente, bem como à saúde dos trabalhadores.

Como tratamos no Capítulo 2, a Constituição de 1988 tutela a proteção do meio ambiente em seu artigo $225 ;^{399}$ e a tutela constitucional do meio ambiente pode ser compreendida, segundo Cristiane Derani, ${ }^{400}$ sob três aspectos: como um direito fundamental ao meio ambiente ecologicamente equilibrado, como um dever do Estado e da coletividade em defender e preservar o meio ambiente para gerações presentes e futuras e como a prescrição de normas impositivas de conduta, visando assegurar a efetividade do direito ao meio ambiente ecologicamente equilibrado.

Nessa esteira, Maria Isabel Cueva Moraes certeiramente afirma:

O princípio da responsabilização decorre da possibilidade inerente ao Estado Democrático de Direito de aplicação de toda espécie de sanção àquele que ameace ou lese o meio ambiente, sendo fundamental para a operatividade dos demais princípios já analisados. Pressupõe que sejam compelidos eventuais responsáveis a executar seus deveres ou responder por suas ações, já que o Estado articula todo um sistema de segurança para a sociedade, que se quebrado pelo dano ambiental, não conta com um sistema eficaz de compensação, razão pela qual a atual sociedade de

\footnotetext{
399 “Art. 225. Todos têm direito ao meio ambiente ecologicamente equilibrado, bem de uso comum do povo e essencial à sadia qualidade de vida, impondo-se ao Poder Público e à coletividade o dever de defendê-lo e preservá-lo para as presentes e futuras gerações."

${ }^{400}$ DERANI, Cristiane. Direito ambiental econômico. São Paulo: Saraiva, 2008. p. 250-252.
} 
risco exige que o poluidor seja responsável pelos seus atos. Nessa atual acepção, a responsabilização desdobra-se nos seus diversos tipos, civil, administrativo, penal, ou mesmo intercomunitário. A dimensão econômica do princípio da responsabilização desdobra-se no princípio do poluidor-pagador, que representa a inserção de imputação de custos ambientais relacionada às atividades dos produtores $^{401}$ (grifos nossos).

De acordo com Antonio Herman Benjamin,

O princípio poluidor-pagador é aquele que impõe ao poluidor o dever de arcar com as despesas de prevenção, reparação e repressão da poluição. $\mathrm{Ou}$ seja, estabelece que o causador da poluição e da degradação dos recursos naturais deve ser o responsável principal pelas consequências de sua ação (ou omissão). ${ }^{402}$

O princípio do poluidor-pagador (Verursacherprinzip) visa, como explica Cristiane Derani, à internalização dos custos relativos externos de deterioração ambiental. Assevera essa autora que em consequência há um maior cuidado em relação ao potencial poluidor da produção, na busca de uma satisfatória qualidade do meio ambiente. E, pela aplicação desse princípio, impõe-se ao "sujeito econômico" (produtor, consumidor, transportador), que nesta relação pode causar um problema ambiental, arcar com os custos da diminuição ou afastamento do dano. ${ }^{403}$

As dimensões do princípio do poluidor-pagador, de acordo com Derani, valendose das lições de Klöpfer, são quatro, a saber: a dimensão objetivo-racional-econômica, a social-ético-normativa, a político-ambiental e a jurídico-normativa. ${ }^{404}$

A primeira dimensão do princípio supramencionado refere-se não apenas aos custos ambientais, como também aos custos das medidas preventivas necessárias à preservação do meio ambiente. Já a perspectiva social ético-normativa se traduz na ideia de que a valorização econômica dos recursos naturais não pode implicar aumento das desigualdades sociais, devendo haver equidade na distribuição dos custos das medidas

\footnotetext{
${ }^{401}$ MORAES, Maria Isabel Cueva. A negociação coletiva ambiental trabalhista e seus frutos. 2008. Dissertação (Mestrado) - Faculdade de Direito da USP, São Paulo, p. 39.

402 BENJAMIN, Antonio Herman V. O princípio poluidor-pagador e a reparação do dano ambiental. In: (Coord.). Dano ambiental: prevenção, reparação e repressão. São Paulo: RT, 1993. p. 227.

${ }^{403}$ DERANI, Cristiane. Direito ambiental econômico. São Paulo: Saraiva, 2008. p. 142.

${ }^{404}$ Idem, ibidem, p. 146.
} 
ambientais. Na perspectiva político-ambiental reúnem-se as dimensões anteriores para que seja classificado e, por conseguinte, responsabilizado o poluidor-pagador. E por fim o aspecto jurídico-normativo apresenta as diversas formas jurídicas de responsabilização do poluidor-pagador. Aqui, acrescenta Derani, valem normas de responsabilização e normas que descrevem princípios; afirma que a determinação do poluidor-pagador depende de definição normativa da política ambiental.

Assim, cabe atuação estatal, da qual deve participar ativamente o particular, no sentido da diminuição da atividade danosa, como sustenta Cristiane Derani:

O custo a ser imputado ao poluidor não está exclusivamente vinculado à imediata reparação do dano. $O$ verdadeiro custo está numa atuação preventiva, consistente no preenchimento da norma de proteção ambiental. O causador pode ser obrigado pelo Estado a mudar o seu comportamento ou a adotar medidas de diminuição da atividade danosa. Dentro do objetivo estatal de melhora do ambiente deve, então, participar ativamente o particular. De fato, o que se estaria praticando seria a Não poluição ${ }^{405}$ (grifos nossos).

No entanto, em determinadas situações não há possibilidade de eliminação ou diminuição da atividade danosa, que é o que ocorre com o trabalho penoso. Sugere Cristiane Derani que no caso de prática de atividade danosa,

[...] poderia o poluidor ser sujeitado a regras estatais, que lhe concederiam a possibilidade de praticar atividades danosas ao meio ambiente, porém pagando uma taxa para tanto, o que, por sua vez, obrigaria a um dispêndio em dinheiro calculado na medida da potencialidade do dano. ${ }^{406}$

Nesse passo, longe de agir com permissividade quanto à exploração da atividade danosa, poluidora, penosa, é preciso admitir, à luz da razão, que em determinadas circunstâncias não há possibilidade de redução ou eliminação do aspecto danoso. Assim sendo, aquele que explorar tal tipo de atividade terá que surportar os ônus dessa exploração; não é possível que esse agente arque com custos iguais aos da atividade não poluidora.

\footnotetext{
${ }^{405}$ DERANI, Cristiane. Direito ambiental econômico. São Paulo: Saraiva, 2008. p. 147.

${ }^{406}$ Idem, ibidem.
} 
Nessa linha, a poluição do meio ambiente do trabalho imputa ao poluidor, no caso, o empregador, a responsabilidade objetiva, portanto, independentemente de culpa ou dolo, pelos danos causados ao meio ambiente e a terceiros, afetados por sua atividade, conforme artigo 14 da Lei 6.938/1981. Observe-se que o princípio do poluidor-pagador visa à internalização dos custos relativos externos de deterioração ambiental, como ensina Derani.

Logo, não pode a sociedade se responsabilizar pelos custos sociais oriundos das atividades empresariais; a empresa deve arcar com tais despesas, mesmo porque é a empresa que corre os riscos da atividade econômica, à luz do artigo $2 .^{\circ}$ da CLT, e o empregador deve assumir os ônus decorrentes do contrato de trabalho, em especial, os relativos à saúde e à integridade física dos empregados.

Em contraponto à internalização dos custos, cabe examinar as chamadas externalidades, que, segundo Fábio Nusdeo, decorrem do fato de, em uma atividade econômica, nem sempre, ou raramente, todos os custos e os respectivos benefícios recaírem sobre a unidade responsável pela sua condução. Por essa razão, a externalidade é chamada de custo externo ou custo social, conforme identificáveis ou não aqueles que sofrem os efeitos. Assim, quando as externalidades redundam em algum custo para alguém, são chamadas de negativas; quando beneficiam alguém, são denominadas positivas. $^{407}$

Ensina Fábio Nusdeo que não é apenas no campo da poluição ambiental que surgem as externalidades negativas; estas podem se dar até em uma relação de vizinhança. E no campo das relações do trabalho,

[...] elas existem sob a forma dos riscos de acidentes do trabalho e das doenças profissionais, adquiridas em anos de exercício de tarefas insalubres, perigosas ou em ambientes inadequados, como a silicose, que afeta o organismo daqueles expostos a partículas suspensas no ar, provenientes, entre outras origens, do processo de fabricação e estocagem do cimento.

É patente não se incluir a silicose no custo normal incorrido por qualquer trabalhador e representado pela renúncia ao lazer, pelo desgaste próprio

${ }^{407}$ NUSDEO, Fábio. Curso de economia: introdução ao direito econômico. São Paulo: RT, 2000. p. 151154. 
da sua atividade, cansaço e outros da espécie. O salário a ele pago não compensa a doença, a qual pode representar a invalidez ou a própria morte. Representa, pois, um custo incompensado a ele imposto e, portanto, uma externalidade negativa ou deseconomia externa. ${ }^{408}$

Como é ínsito ao conceito da chamada externalidade negativa que o custo externo recaia sobre outrem, isto é, aquele que sofre os efeitos não é o responsável pela produção; a tendência será mantê-las assim, salvo uma decidida ação do poder público no sentido de sua internalização, como alerta $N u s d e o,{ }^{409}$ pois o produtor voltado para a redução de seus custos terá sempre o impulso de tornar externos aqueles que não conseguir reduzir. Cumpre então perquirir o significado da internalização dos custos externos ou sociais, objetivo do princípio do poluidor-pagador, e para tanto é preciso examinar a natureza e as causas básicas da existência das externalidades.

Ensina esse autor que no sistema de propriedade privada de todos os bens econômicos é a propriedade que engendra a cadeia de trocas própria do mercado e, em última análise, embasa os preços. As externalidades correspondem a custos ou benefícios não compensados pecuniariamente, isto é, transferidos sem preço. A escassez impõe uma contenção no uso do bem, mas a contenção somente é obtida pela imposição de um preço, o que na ausência da propriedade não é possível. Dessa forma, a comunidade se serve de bens escassos como se livres fossem, exaurindo-os ou deteriorando-os; essa é a raiz do problema, diz Fábio Nusdeo. Prossegue ilustrando que o ponto em comum entre o congestionamento nas estradas, a poluição e a exaustão de recursos é a ausência ou não exercício mercantil da propriedade. Assim, o rio é poluído porque não se cobra um preço pelo uso de suas águas; os recursos naturais ou espécies animais exaurem-se por não terem seus direitos de propriedade firmados. ${ }^{410}$

E o Brasil conta com uma lei especialmente destinada à proteção dos interesses difusos, a Lei 7.347, de 24 de julho de 1985, que disciplina a ação civil pública de responsabilidade por danos causados ao meio ambiente, ao consumidor, a bens e direitos de valor artístico, estético, histórico, turístico e paisagístico. E, como lembra Fábio

\footnotetext{
${ }^{408}$ NUSDEO, Fábio. Curso de economia: introdução ao direito econômico. São Paulo: RT, 2000. p. 154.

${ }^{409}$ Idem, ibidem, p. 156.

${ }^{410}$ Idem, p. 157-158.
} 
Nusdeo, os exemplos de interesses difusos prendem-se, na sua maioria, à figura das externalidades.

As dificuldades com a internalização ou privatização dos efeitos negativos, representados pelos custos sociais, são extremamente sérias; por isso, as normas jurídicas nesse campo têm a finalidade de promover a internalização daqueles custos pela unidade produtora. Nesse sentido, os dispositivos típicos de poder de polícia em vários setores, como os relativos à segurança e higiene do trabalho, no campo do Direito Trabalhista.

Exemplo que se pode adotar para ilustrar a aplicação do princípio do poluidorpagador é o que se verifica em alguns países que estruturam cobranças tributárias destinadas a transferir recursos dos fabricantes de cigarro para os centros hospitalares onde estão internos os vitimados pelo tabaco, amônia, que é um produto destinado a aumentar a dependência e outros subprodutos do tabagismo. A justificativa, destaca Fábio Nusdeo, é sempre a mesma: se o tratamento implica altos custos para a sociedade, e em especial para a Previdência Social, natural que arquem com eles os seus agentes causadores ${ }^{411}$ (grifamos).

Do princípio do poluidor-pagador decorrem aspectos importantes para o aplicador do direito ambiental: a) a responsabilidade civil objetiva, que já era prevista na Lei de Política Nacional do Meio Ambiente - Lei 6.938/1981, e foi recepcionada pela Constituição Federal de 1988 - aquele que não evita o dano responde objetivamente pelos prejuízos causados, conforme $\S 3 .^{\circ}$ do artigo 225 da Carta; b) prioridade da recuperação específica do dano ambiental; e c) solidariedade para suportar os danos causados ao meio ambiente, conforme elenca Raimundo Simão de Melo. ${ }^{412}$

Há tendência mundial de se buscar efetivamente reparação pelos danos causados não somente ao meio ambiente, como também a terceiros atingidos pela atividade poluidora; e nesse sentido dispõe o $§ 1 .^{\circ}$ do artigo 14 da LPNMA, Lei 6.938/1981, de que sem obstar a aplicação de penalidades no dispositivo, o poluidor é obrigado a indenizar ou

${ }^{411}$ NUSDEO, Fábio. Curso de economia: introdução ao direito econômico. São Paulo: RT, 2000. p. 159.

412 MELO, Raimundo Simão de. Direito ambiental do trabalho e a saúde do trabalhador: responsabilidades legais, dano material, dano moral, dano estético, indenização pela perda de uma chance, prescrição. São Paulo: LTr, 2008. p. 48. 
reparar os danos causados no meio ambiente e a terceiros, afetados por sua atividade, independentemente da existência de culpa. Trata-se do acolhimento da teoria da responsabilidade decorrente do risco da atividade, sem necessidade de prova da existência de culpa do agente.

Guilherme Guimarães Feliciano sustenta a imputação objetiva penal ambiental, quando o agente cria um risco em nível superior ao permitido, caracterizando-se o risco proibido ou um incremento do risco permitido. Nessas hipóteses, não se fala em relação de causalidade, e sim em imputação objetiva. A diferença entre a relação de causalidade e a imputação objetiva reside no fato de que a primeira envolve o nexo naturalístico e na segunda o nexo é normativo. ${ }^{413}$

No que tange à reparação específica do dano, em matéria ambiental, não sendo possível a recomposição, determina-se pagamento de indenização genérica pelo dano, sem excluir a possibilidade de reparação pelos danos individualmente causados a terceiros. E nesse caso em que se enquadra o dano ao meio ambiente de trabalho, destaca Raimundo Simão de Melo, que deverá ser recomposto, sem se excluir o direito de o trabalhador lesado pleitear judicialmente a reparação concreta do dano ao seu patrimônio material e/ou moral: exemplifica com um caso de uma empresa poluidora do meio ambiente de trabalho, por altos índices de ruído, e que em consequência deixa vários trabalhadores surdos. Pode haver ajuizamento de ação coletiva buscando a prevenção do meio ambiente, com a eliminação do ruído excessivo, uma indenização genérica por dano ao meio ambiente; além disso, os trabalhadores submetidos ao ambiente insalubre poderão pleitear indenização individual não somente pelo pagamento do adicional de insalubridade, como também em caso de perda auditiva, buscar indenizações por danos material e moral. ${ }^{414}$

É o alcance do princípio do poluidor-pagador, como salienta Raimundo Simão de Melo, e sua finalidade é encarecer o custo para o poluidor, a fim de que as medidas de cunho preventivo sejam adotadas.

${ }^{413}$ FELICIANO, Guilherme Guimarães. Teoria da imputação objetiva no direito penal ambiental brasileiro. São Paulo: LTr, 2005. p. 112-117.

${ }^{414}$ MELO, Raimundo Simão de. Direito ambiental do trabalho e a saúde do trabalhador: responsabilidades legais, dano material, dano moral, dano estético, indenização pela perda de uma chance, prescrição. São Paulo: LTr, 2008. p. 49. 


\subsection{Atuação do Ministério Público do Trabalho}

A Constituição Federal de 1988, no capítulo IV, "Das funções essenciais à Justiça", definiu no artigo 127 o Ministério Público como "instituição permanente essencial à função jurisdicional do Estado", cuja incumbência é a "defesa da ordem jurídica, do regime democrático e dos interesses sociais e individuais indisponíveis". Assim, suas funções institucionais foram ampliadas, voltadas para a tutela dos direitos e interesses mais relevantes do cidadão e da sociedade.

O Ministério Público abrange: I - O Ministério Público da União, que compreende: o Ministério Público Federal; o Ministério Público do Trabalho; o Ministério Público Militar; o Ministério Público do Distrito Federal e Territórios; II - o Ministério Público dos Estados.

E o Ministério Público do Trabalho, que antes da vigência da Carta de 1988 se encontrava subordinado ao Poder Executivo (artigo 736 da CLT), em especial, sofreu profunda alteração em suas funções, cabendo-lhe a tutela do meio ambiente do trabalho, da saúde e da integridade física e psíquica dos trabalhadores, como direitos fundamentais do cidadão. $^{415}$

E, como dispõe o artigo 129, entre as funções institucionais do Ministério Público encontra-se a promoção do inquérito civil e da ação civil pública para a proteção do patrimônio público e social, do meio ambiente e de outros interesses difusos e coletivos, frequentes nas questões de segurança e saúde do trabalho. Ademais, a Lei Orgânica do Ministério Público da União, a Lei Complementar 75, de 20.05.1993, conferiu ao Parquet a competência para promover a Ação Civil Pública, no âmbito da Justiça do Trabalho, sendo órgão legitimado para a tutela jurisdicional na defesa de ambientes do trabalho sadios e adequados.

Como lembra Raimundo Simão de Melo, na tutela do meio ambiente de trabalho o Ministério Público atua também como custos legis, pois, de acordo com a Lei 7.347/1985

\footnotetext{
${ }^{415}$ MELO, Raimundo Simão de. Direito ambiental do trabalho e a saúde do trabalhador: responsabilidades legais, dano material, dano moral, dano estético, indenização pela perda de uma chance, prescrição. São Paulo: LTr, 2008. p. 81.
} 
(Lei de Ação Civil Pública, artigo $5^{\circ}, \S 1^{\circ}$ ), se não for parte, o Parquet atuará obrigatoriamente como fiscal da lei; assim, deve atuar nas ações coletivas ambientais, sob pena de nulidade do processo. ${ }^{416}$

Salientamos a seguir os mais importantes instrumentos de defesa e tutela do meio ambiente do trabalho, manejados pelo Ministério Público.

O inquérito civil é procedimento administrativo de investigação; com natureza inquisitiva, instaurado e presidido pelo Ministério Público. Tal instrumento nasceu com a Lei 7.347/1985, sendo depois consagrado pela Constituição Federal, conforme artigo 129, III, da Constituição Federal, e art. 6. ${ }^{\circ}$, VII, da Lei Complementar 75/1993 (Lei Orgânica do Ministério Público da União), além de outros diplomas legais, como a Lei 7.853/1989 (proteção das pessoas portadoras de deficiência).

É suscitado mediante denúncia de qualquer pessoa ou instaurado de ofício por qualquer dos integrantes do MPT, por meio de notícias da imprensa ou por qualquer outra fonte que lhe permita tomar conhecimento do ocorrido. E como assegura o $\S 1 .^{\circ}$ do artigo 8. ${ }^{\circ}$ da Lei de Ação Civil Pública, "O Ministério Público poderá instaurar, sob sua presidência, inquérito civil, ou requisitar, de qualquer organismo público ou particular, certidões, informações, exames ou perícias, no prazo que assinalar, o qual não poderá ser inferior a $10(\mathrm{dez})$ dias úteis".

Aspecto importante e bastante discutido é o relativo ao valor da prova obtida no inquérito civil. Durante o seu trâmite, o Ministério Público do Trabalho obtém elementos probatórios, como laudos técnicos requisitados, vistorias e testemunhos, que são carreados aos autos de uma ação civil pública ou outra medida judicial. Explica Raimundo Simão de Melo que esses elementos probatórios não precisam necessariamente ser repetidos em Juízo durante a instrução processual. Contudo, observa esse autor, sua força probante é relativa, pois no inquérito civil, como procedimento inquisitivo, não há contraditório; o procurador é o destinatário das provas. No processo penal, diferentemente do civil, é necessária e fundamental a repetição das provas do inquérito policial. Já no processo do

\footnotetext{
${ }^{416}$ MELO, Raimundo Simão de. Direito ambiental do trabalho e a saúde do trabalhador: responsabilidades legais, dano material, dano moral, dano estético, indenização pela perda de uma chance, prescrição. São Paulo: LTr, 2008. p. 82.
} 
trabalho, com principiologia própria, e aplicação do Código de Processo Civil como fonte subsidiária (artigo 769 da CLT), será necessária a repetição das provas somente quando impugnadas especificamente pelo réu, ou por decisão do juiz, que é condutor do processo e a quem são dirigidas as provas. ${ }^{417}$

É importante ressaltar que o inquérito civil não é condição sine qua non para ajuizamento da Ação Civil Pública ou de outra ação coletiva qualquer.

Outro importante instrumento, o Termo de Ajustamento de Conduta (TAC) foi criado pelo Código de Defesa do Consumidor (CDC), Lei 8.078/1990, que acrescentou o $\S$ 6. ${ }^{\circ}$ do artigo 5. ${ }^{\circ}$ da Lei 7.347/1985 (Lei de Ação Civil Pública), tornando o inquérito civil cada vez mais um instrumento de cidadania, como preleciona Raimundo Simão de Melo, valendo-se das palavras de Francisco Antonio de Oliveira: "[...] o compromisso de ajustamento se traduz em meio hábil de a parte adequar a sua conduta às exigências legais e deve ser um fim perseguido por todos os legitimados". 418

São legitimados para tomar o compromisso de ajustamento não somente o Ministério Público, como também a União, os Estados, Municípios, Distrito Federal e órgãos públicos, na forma do artigo $5^{\circ}$ da Lei 7.347/1985.

O objeto e a finalidade do termo de ajustamento de conduta, como estabelece a Resolução 23/2007 do Conselho Nacional do Ministério Público (CNMP), no seu artigo 14, são:

O Ministério Público poderá firmar compromisso de ajustamento de conduta, nos casos previstos em lei, com o responsável pela ameaça ou lesão aos interesses ou direitos mencionados no artigo $1 .^{\circ}$ desta Resolução, visando à reparação do dano, à adequação da conduta às exigências legais ou normativas e, ainda, à compensação e/ou indenização pelos danos que não possam ser recuperados.

\footnotetext{
${ }^{417}$ MELO, Raimundo Simão de. Ação civil pública na justiça do trabalho. São Paulo: LTr, 2008. p. 63.

${ }^{418}$ Idem, ibidem, p. 69.
} 
Assim, o objeto do termo de ajustamento de conduta pode ser uma obrigação de fazer ou não fazer, o que constitui regra geral; nada obsta, e a lei não veda que o TAC possa constituir-se em uma obrigação de dar.

O Termo de Ajustamento de Conduta (TAC), ressalta Raimundo Simão de Melo, é

[...] importante instrumento de efetivação do Direito do Trabalho, sendo indiscutível a efetividade da defesa do meio ambiente e da saúde do trabalhador porque o bem em discussão é a própria vida, que não pode esperar por demoradas soluções advindas do Poder Judiciário [...]. ${ }^{419}$

Para ilustrar, descreve o termo de compromisso tomado no inquérito civil da PRT da 15. ${ }^{a}$ Região, em que foram ajustadas, entre outras, condições de trabalho voltadas à prevenção de acidentes, eliminação ou neutralização de agentes agressivos, e demais medidas, voltadas à melhoria do meio ambiente de trabalho. ${ }^{420}$

De acordo com o disposto na Lei de Ação Civil Pública, a natureza jurídica do termo de ajustamento de conduta é de título extrajudicial, executável direta e imediatamente perante a Justiça do Trabalho. Contudo, a grande importância desse instrumento está na instrumentalização das normas de direito material, sempre que possível, de maneira preventiva e coletiva.

Por fim, a Ação Civil Pública, espécie das ações coletivas, é ajuizada quando não se consegue o atendimento do cumprimento das exigências legais por meio dos Termos de Ajustamento de Conduta (TACs). Tal ação tem por finalidade proteger os direitos e interesses metaindividuais, difusos, coletivos e individuais homogêneos de ameaças e lesões, direitos esses que constituem interesse público primário da sociedade. Permite a

${ }^{419}$ MELO, Raimundo Simão de. Ação civil pública na justiça do trabalho. São Paulo: LTr, 2008. p. 73.

420 "a) a empresa se compromete a partir desta data, a afixar, manter e implementar Ordens de Serviço no estabelecimento, visando a instruir os empregados quanto às precauções a tomar no sentido de evitar acidentes do trabalho e doenças profissionais [...].; b) a empresa se compromete, no prazo de 60 (sessenta) dias, a elaborar e afixar mapa de riscos nos setores de trabalho, nos termos da NR-5, a ser elaborado pela CIPA; [...] d) a empresa se compromete, no prazo de 90 (noventa) dias, a elaborar e implementar Programa de Conservação Auditiva na forma da NR-6, NR-9 e Ordem de Serviço do INSS n. 608, de 5.8.98, DOU 19.08.1998" (Inquérito civil MPT 081 45-02588/99-9, da PRT da 15." Região/SP). 
tutela de direitos de massas, que não encontravam proteção nos mecanismos processuais do direito individual.

Seu objeto está contido nas disposições do artigo 1. ${ }^{\circ}$, I a V, da Lei 7.347/1985. Luís Antônio Camargo de Melo propõe uma ampliação do objeto da ação civil pública (ou ação coletiva), quando ajuizada na defesa de direitos ou interesses individuais homogêneos, principalmente quando os bens tutelados são a liberdade, a saúde e a vida de cidadãos [...]. Assim, ao lado das obrigações de fazer e de não fazer, e do dano moral coletivo, estaria também o dano moral individual (entre as pretensões de caráter individual homogêneo). ${ }^{421}$

Por meio da ACP é possível postular, a teor do artigo 3. ${ }^{\circ}$ da Lei 7.347/1985, a condenação em dinheiro ou no cumprimento da obrigação de fazer ou de não fazer. A condenação em dinheiro, no caso, deve se destinar à recomposição do bem jurídico lesado. A obrigação de fazer ou não fazer engloba todas as medidas e providências tendentes a devolver a dignidade do trabalhador.

Diante de questionamentos existentes e inexistência de controles acerca da efetiva reversão dos valores das condenações por dano moral coletivo nas ações civis públicas ou TACs para o Fundo de Amparo ao Trabalhador (FAT), o Ministério Público do Trabalho tem optado pela conversão do recolhimento ao FAT às obrigações de fazer, como: instalação de posto de saúde, com capacidade para atendimento ambulatorial e primeiros socorros; aquisição de ambulâncias para serviços junto aos postos de saúde; ou aquisição de veículos para pessoas com deficiência.

O juiz poderá, a requerimento da parte interessada ou ex officio, à luz do artigo 12 da Lei 7.347/1985, ou artigo 84 do CDC, conceder mandado liminar, com ou sem justificação prévia, nas hipóteses do cumprimento de obrigação de fazer, de não fazer e de suportar. Trata-se de antecipação de tutela do direito metaindividual postulado, quando estiver presente uma situação de grave e iminente risco, a provocar danos irreversíveis e

${ }^{421}$ PRADO, Erlan José Peixoto do. A ação civil pública e sua eficácia no combate ao trabalho em condições análogas à de escravo: o dano moral coletivo. In: VELLOSO, Gabriel; FAVA, Marcos Neves (Coord.). Trabalho escravo contemporâneo: o desafio de superar a negação. São Paulo: LTr, 2006. p. 192-193. 
irreparáveis à coletividade; sua natureza é satisfativa da tutela definitiva, embora provisória. $^{422}$

Os requisitos para adoção das medidas antecipativas dos artigos 273 e 461 do Código de Processo Civil se mostram incompatíveis com o chamado sistema de jurisdição coletiva, disciplinado nos artigos 11 e 12 da Lei de Ação Civil Pública e no artigo $84, \S 3 .^{\circ}$, do CDC.

São requisitos para a antecipação de tutela nas ações coletivas: a relevância do fundamento da demanda, o chamado fumus boni iuris; justificado receio de ineficácia do provimento final, o periculum in mora.

Há exceção à inaplicabilidade do art. 273 do CPC, com base no seu inciso II, quando estiver caracterizado o abuso do direito de defesa ou manifesto propósito protelatório do réu.

\subsection{Responsabilidade do empregador}

Responsabilidade, que se origina do latim respondere, que significa responder, no sentido amplo do termo é o dever jurídico que obriga uma pessoa em razão de um contrato ou de previsão legal. Assim, a pessoa responsável deve satisfazer a obrigação devida, sob pena de suportar sanções, em decorrência do seu não cumprimento.

A responsabilidade pode ser contratual, aquela resultante das obrigações derivadas de um contrato, ou extracontratual, como ensina Luiz de Pinho Pedreira da Silva, ${ }^{423}$ que é a decorrente de lesão a direito, quando entre o causador do dano e o que sofre inexiste relação jurídica, na qual se possa fundar a indenização, justificando-se esta pelo princípio geral de direito que manda respeitar a pessoa e os bens alheios.

A responsabilidade civil é aquela juridicamente diferenciada dos demais tipos de responsabilidade, como a criminal, a administrativa, a trabalhista etc.

\footnotetext{
${ }^{422}$ MELO, Raimundo Simão de. Ação civil pública na justiça do trabalho. São Paulo: LTr, 2008. p. 120.

${ }^{423}$ SILVA, Luiz de Pinho Pedreira da. A reparação do dano moral no direito do trabalho. São Paulo: LTr, 2004.p. 9.
} 
Existem duas teorias sobre a responsabilidade civil: a teoria monista ou da unidade da culpa, que sustenta que tanto a responsabilidade extracontratual quanto a contratual estão fundadas na culpa; e a teoria dualista, que embasa a responsabilidade extracontratual na culpa e a contratual, no simples descumprimento da avença; o direito civil brasileiro adota a segunda. Nessa esteira, embora a distinção entre ambas não seja estanque, o Código Civil de 2002 cuida da responsabilidade extracontratual nos artigos 186 a 188 e 927 , e a responsabilidade contratual é tratada no artigo 389 e seguintes.

Para que se possa verificar a ocorrência de responsabilidade civil, é preciso que haja alteridade, como explica Pedreira da Silva, valendo-se das lições de Fernando Pessoa Jorge, é necessário que os prejuízos, de cuja imputação se trata, sejam alheios, isto é, tenham sido suportados por pessoa diversa daquela sobre a qual se pretende que o respectivo sacrifício impenda com caráter definitivo. Impõe-se também determinar a autoria, há que se discernir se o fato é imputável ou atribuível ao agente, a fim de que o autor sofra a responsabilidade jurídica. ${ }^{424} \mathrm{O}$ agente responde por participação direta, ou porque o fato imputável ocorreu por atos de outra pessoa, animal ou coisa vinculada, na chamada responsabilidade indireta do agente, como se infere das disposições dos artigos 932 e 933 do Código Civil. ${ }^{425}$

Constitui a responsabilidade civil uma resposta ao ato ilícito pela reparação do direito lesado, sendo a busca incumbência da vítima, como alerta Raimundo Simão de Melo, pois usualmente a ofensa se dá contra interesse privado. Difere da responsabilidade

${ }^{424}$ SILVA, Luiz de Pinho Pedreira da. A reparação do dano moral no direito do trabalho. São Paulo: LTr, 2004. p. 9-11.

425 “Art. 932. São também responsáveis pela reparação civil:

I - os pais, pelos filhos menores que estiverem sob sua autoridade e em sua companhia;

II - o tutor e o curador, pelos pupilos e curatelados, que se acharem nas mesmas condições;

III - o empregador ou comitente, por seus empregados, serviçais e prepostos, no exercício do trabalho que lhes competir, ou em razão dele;

IV - os donos de hotéis, hospedarias, casas ou estabelecimentos onde se albergue por dinheiro, mesmo para fins de educação, pelos seus hóspedes, moradores e educandos;

$\mathrm{V}$ - os que gratuitamente houverem participado nos produtos do crime, até a concorrente quantia.

Art. 933. As pessoas indicadas nos incisos I a V do artigo antecedente, ainda que não haja culpa de sua parte, responderão pelos atos praticados pelos terceiros ali referidos." 
penal, quando a infração cometida pelo agente viola norma de direito público com perturbação à ordem social, incumbindo ao próprio Estado buscar a punição do acusado. Em ambas encontra-se a infração a um dever por parte do agente causador, que deve responder pelo ato praticado. ${ }^{426}$

Como dissemos, a responsabilidade contratual deriva de um contrato celebrado entre as partes, escrito ou tácito; o dever de indenizar surge quando um dos contratantes descumpre obrigação constante do pacto. Exemplo típico de responsabilidade contratual é a que decorre do contrato de trabalho, por meio do qual o trabalhador vende a sua força de trabalho e o empregador, além do pagamento do salário, assume demais obrigações, entre as quais a de manter a integridade física e psíquica daquele, em função do trabalho e do contrato celebrado. ${ }^{427}$

De todo modo, há uma regra universalmente estabelecida, de cunho antes moral que jurídico, no sentido de que todo aquele que causar dano a outrem fica obrigado a repará-lo. Decorrem daí os pressupostos da responsabilidade civil: a) ação ou omissão do agente; b) culpa ou dolo do agente; c) relação de causalidade entre o ato e o dano; e d) o dano experimentado pela vítima, como preveem os artigos 186, combinado com o artigo 927 do Código Civil de 2002. ${ }^{428}$

Esses são pressupostos inerentes à responsabilidade subjetiva ou aquiliana, adotada por parte da doutrina, que entende, por exemplo, que nos casos de acidente de trabalho a responsabilidade do empregador é subjetiva, ou seja, sua imposição depende da

${ }^{426}$ MELO, Raimundo Simão de. Direito ambiental do trabalho e a saúde do trabalhador: responsabilidades legais, dano material, dano moral, dano estético, indenização pela perda de uma chance, prescrição. São Paulo: LTr, 2008. p. 184.

${ }^{427}$ Idem, ibidem, p. 192.

${ }^{428}$ Art. 186. "Aquele que, por ação ou omissão voluntária, negligência ou imprudência, violar direito e causar dano a outrem, ainda que exclusivamente moral, comete ato ilícito."

Art. 927. "Aquele que, por ato ilícito (arts. 186 e 187), causar dano a outrem, fica obrigado a repará-lo." 
comprovação do dolo ou culpa; tal entendimento lastreia-se na previsão do artigo $7 .^{\circ}$, inciso XXVIII, da Constituição Federal. ${ }^{429}$

A jurisprudência dos nossos Tribunais admite tanto a responsabilidade subjetiva quanto a objetiva, dependendo do tipo de atividade do empregador; nesse passo, pode-se afirmar que uma teoria não exclui a outra.

As Cortes trabalhistas têm adotado a teoria da responsabilidade subjetiva, quando não se trata de atividade de risco. Nesse sentido, o posicionamento de julgados do Tribunal Regional do Trabalho da 2. ${ }^{a}$ Região, de demais Regionais e do TST, é de que o nexo de causalidade, que é a relação de causa e efeito entre a conduta culposa ou dolosa do agente (responsabilidade subjetiva) e o dano suportado pela vítima deve ser cabalmente comprovado. Assim entendeu o Relator Francisco Ferreira Jorge Neto em julgado da 12. ${ }^{a}$ Turma do TRT da 2. ${ }^{a}$ Região, que para a responsabilização civil da empregadora por acidente de trabalho há que se perquirir a existência de ato comissivo ou omissivo, dolo ou culpa, dano e nexo causal, de acordo com a teoria subjetiva, sendo que o nexo causal deve ser cabalmente comprovado. Ressaltou esse relator que, caso inexistente o nexo causal, também não há o dever de indenizar. ${ }^{430}$

Determinados julgados afastam o entendimento favorável à responsabilidade objetiva do empregador sob o fundamento de que, nos termos da legislação previdenciária brasileira, o empregador já custeia o seguro previdenciário de seu empregado a fim de assegurar os riscos; nesse passo, a responsabilidade civil somente lhe seria imputada em caso de comprovação de culpa ou dolo, como exemplifica Acórdão da 18. ${ }^{\text {a }}$ Turma do TRT da $2 .^{\text {a }}$ Região. ${ }^{431}$

\footnotetext{
${ }^{429}$ Art. 7. " "São direitos dos trabalhadores urbanos e rurais, além de outros que visem à melhoria de sua condição social: [...] XXVIII - seguro contra acidentes de trabalho, a cargo do empregador, sem excluir a indenização a que este está obrigado, quando incorrer em dolo ou culpa."

${ }^{430}$ Rel. Francisco Ferreira Jorge Neto, Acórdão 20120989969, Processo 20120049923, DJ 31.08.2012. Disponível em: <http://trtsp.jus.br>. Acesso em: 23 nov. 2012.

${ }^{431}$ Rel. Regina Vasconcelos, Acórdão 20120884903, Processo 20120007666, DJ 10.08.2012. Disponível em: <http://trtsp.jus.br>. Acesso em: 23 nov. 2012.
} 
E mesmo diante da inexistência de causalidade direta, presente, no entanto, a concausa no exercício da atividade laboral para a ocorrência da eclosão da doença ocupacional, tem-se entendido como cabível a responsabilidade civil, também mediante a comprovação do dolo ou culpa, nos termos do julgado do TRT da 4. ${ }^{a}$ Região. ${ }^{432}$

O Egrégio Supremo Tribunal Federal tem afastado a teoria da responsabilidade objetiva sob o fundamento de que a indenização por danos materiais ou morais, exigível pelo empregado perante o empregador na Justiça do Trabalho, tem assento constitucional, mas somente para o caso da ocorrência de culpa ou dolo do empregador, nos termos do art. 7. ${ }^{\circ}$, XXVIII, da Constituição Federal, o que descarta de plano a aplicação da teoria do risco ou da responsabilidade objetiva previstas legal (CC, art. 927, parágrafo único) ou constitucionalmente $\left(\mathrm{CF}\right.$, art. $37, \S 6^{\circ} .^{\prime}$, uma vez que, na compreensão do STF, a responsabilidade trabalhista é exclusivamente contratual, não comportando a civil extracontratual (conforme ADC 16-DF, Rel. Min. Cezar Peluso, DJe 09.09.2011). ${ }^{433}$

Outra parte da doutrina sustenta que a responsabilidade do empregador é objetiva; elenca Raimundo Simão de Melo renomados autores, defensores dessa teoria, e, valendo-se da lição de Caio Mário da Silva Pereira, salienta que o Direito moderno não visa ao autor do dano, e sim à vítima. ${ }^{434}$

Entende-se que os direitos dos trabalhadores previstos no artigo 7..$^{\circ}$ da Carta Magna são direitos básicos, patamares mínimos de civilidade abaixo dos quais não se pode vislumbrar trabalho digno ou decente. Deduz-se assim do próprio caput desse comando constitucional, quando dispõe: "além de outros que visem à melhoria de sua condição social", complemento que aponta no sentido da valorização do trabalhador. Nessa linha, o artigo $1 .^{\circ}$, incisos III e IV, preceitua que a dignidade da pessoa humana e os valores sociais do trabalho e da livre-iniciativa são fundamentos da República Federativa do Brasil; no

${ }^{432}$ Rel. Ana Rosa Pereira Zago Sagrilo, Processo 0148800-47.2007.5.04.0661, j. 25.03.2010. Disponível em: $<$ http://www.trt4.jus.br>. Acesso em: 23 nov. 2012.

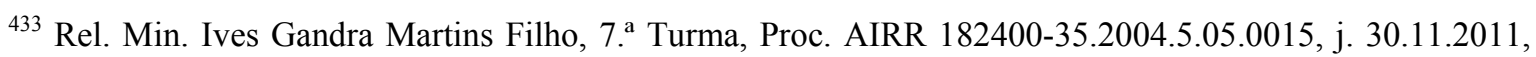
DEJT 02.12.2011. Disponível em: <http://www.tst.jus.br>. Acesso em: 23 nov. 2012.

${ }^{434}$ MELO, Raimundo Simão de. Direito ambiental do trabalho e a saúde do trabalhador: responsabilidades legais, dano material, dano moral, dano estético, indenização pela perda de uma chance, prescrição. São Paulo: LTr, 2008. p. 190. 
mesmo sentido, o artigo 170 da Constituição contém o preceito de que a ordem econômica deve ser fundada na valorização do trabalho.

Dessa forma, qualquer direito ou norma que melhore a condição do trabalhador deve prevalecer perante o direito mínimo previsto no artigo 7. ${ }^{\circ}$ do Diploma Maior.

O direito brasileiro, por meio do Código Civil e leis esparsas, contém várias hipóteses de responsabilidade objetiva. Exemplo que se coaduna com o espírito constitucional foi a novidade trazida com o parágrafo único do artigo 927 do Código Civil de 2002:

Haverá obrigação de reparar o dano, independentemente de culpa, nos casos especificados em lei, ou quando a atividade normalmente desenvolvida pelo autor do dano implicar, por sua natureza, risco para os direitos de outrem (grifo nosso).

Nesses termos, haverá responsabilidade do agente, sem aferição de culpa ou dolo, quando a atividade for de risco. Vimos no capítulo anterior que, do ponto de vista da saúde do trabalhador, risco é um conceito que se refere à possibilidade/probabilidade de ocorrência de eventos que tenham consequências negativas à saúde, ou seja, que possam causar algum tipo de agravo ou dano à saúde de um indivíduo, de um grupo populacional ou ao ambiente. Nessa linha, o posicionamento jurisprudencial do Tribunal Superior do Trabalho, de que a regra inserta no inciso XXVIII do artigo $7 .^{\circ}$ da Constituição Federal não elide a incidência de outro sistema de responsabilidade civil mais favorável ao empregado, como é a hipótese do art. 927, parágrafo único, do Código Civil, que deve incidir todas as vezes em que a atividade desenvolvida pelo empregado na empresa ocasionar riscos superiores àqueles inerentes ao trabalho prestado de forma subordinada, como se dá na hipótese de transporte de valores, pois, mesmo com a utilização de todos de meios preventivos recomendados pelas autoridades de segurança pública, permitiu a ocorrência de lesão à integridade física do obreiro, vítima de tiro desferido durante assalto. ${ }^{435}$

${ }^{435}$ Rel. Min. Vieira de Mello Filho, Proc. RR-127700-97.2004.5.07.0001, j. 16.05.2012. Disponível em: $<$ http://www.tst.jus.br>. Acesso em: 23 nov. 2012. 
A conceituação de atividade de risco expendida no campo do direito não se distancia da orientação da área de saúde do trabalhador. É oportuno acrescentar a definição a que se chegou a esse respeito na I Jornada de Direito Civil do Conselho de Justiça Federal, por meio do Enunciado 38:

A responsabilidade fundada no risco da atividade, como prevista na segunda parte do parágrafo único do art. 927 do Código Civil, configurase quando a atividade normalmente desenvolvida pelo autor do dano causar a pessoa determinada um ônus maior do que aos demais membros da coletividade. ${ }^{436}$

Diz Raimundo Simão de Melo que a teoria do risco representou o mais importante avanço da teoria objetiva, e tem raízes nos princípios da justiça e da equidade, diante da complexidade da vida moderna, que trouxe a multiplicidade dos acidentes, com transtornos para as vítimas anônimas, diante da insegurança pela impossibilidade de provarem a culpa do agente, como ocorre nos acidentes em transporte aéreo. Ensina esse autor que tal teoria é explicada em quatro subespécies: teoria do risco integral, teoria do risco profissional, teoria do risco proveito e teoria do risco criado.

A primeira, teoria do risco integral, abolindo a ideia de culpa, proclama que qualquer fato, culposo ou não, deve assegurar à vítima a reparação do dano. Por não indagar sequer como ocorreu o dano, não permitindo qualquer excludente, não prosperou. A teoria do risco profissional também não cogita da ideia de culpa; o dever de indenizar surge quando o fato decorre da atividade ou profissão da vítima; a teoria do risco proveito tem como suporte doutrinário a ideia de que quem retira algum proveito ou vantagem do fato causador do dano deve repará-lo, independentemente da existência de culpa; em sentido restrito, proveito está ligado à ideia de riqueza, ficando a responsabilidade restrita aos comerciantes ou industriais, restringindo sua aplicação. Por fim, pela teoria do risco criado, quem empreende alguma atividade, lucrativa ou não, responde pelos danos causados a outrem. Não há falar em culpa do agente ou na ilicitude do ato. Essa teoria procura colocar a vítima inocente em igualdade de condições em que se acham os novos empreendimentos, pela crescente industrialização e intensificação de atividades potencialmente perigosas.

${ }^{436}$ AGUIAR JÚNIOR, Ruy Rosado de (Org.). Jornada de Direito Civil. Brasília: CJF, 2007. p. 21. 
Ressalta Raimundo Simão de Melo que tal teoria tem fundamentos com raízes nas ideias de solidariedade humana, sentimento de responsabilidade, segurança e socialização do direito, sendo a mais consentânea com a evolução do Direito. ${ }^{437}$

Saliente-se que determinadas Subseções de Dissídio Individual do TST posicionam-se no sentido de que se aplica a responsabilidade objetiva no caso de acometimento de LER/DORT em trabalhador bancário, pois tal atividade é de risco acentuado. $^{438}$

Diante do exposto, reitere-se que as obrigações do empregador decorrem, inicialmente, da responsabilidade contratual; o descumprimento dessas obrigações, propiciando ocorrência de dano, gera a responsabilidade da reparação.

Saliente-se que a Constituição Federal prevê que os empregadores são obrigados a reduzir os riscos inerentes ao trabalho, por meio de normas de saúde, higiene e segurança, nos termos do inciso XXII do artigo $7 .^{\circ}$ da Carta.

Por sua vez, a CLT, em seu Capítulo V - Da Segurança e Medicina do Trabalho , dispõe especificamente nos artigos 154 a 201 quais os direitos e obrigações inerentes aos empregados, empregadores e ao Governo no tocante à busca pela proteção à vida e promoção da segurança e saúde nas relações do trabalho. Tal obrigação é reiterada no artigo 157 da CLT e seus incisos, que estabelece que cabe às empresas, também, instruir os empregados quanto às precauções a tomar no sentido de evitar acidentes do trabalho ou doenças ocupacionais. $^{439}$

${ }^{437}$ MELO, Raimundo Simão de. Direito ambiental do trabalho e a saúde do trabalhador: responsabilidades legais, dano material, dano moral, dano estético, indenização pela perda de uma chance, prescrição. São Paulo: LTr, 2008. p. 198-199.

${ }^{438}$ Rel. Min. Carlos Alberto Reis de Paula, Subseção I Especializada em Dissídios Individuais, Processo EED-RR 17300-43.2007.5.01.0012, j. 15.12.2011, DEJT 03.02.2012. Disponível em: $<$ http://www.tst.jus.br>. Acesso em: 23 nov. 2012.

439 "Cabe às empresas: I - cumprir e fazer cumprir as normas de segurança e medicina do trabalho; II instruir os empregados, através de ordens de serviço, quanto às precauções a tomar no sentido de evitar acidentes do trabalho ou doenças ocupacionais; III - adotar as medidas que lhe sejam determinadas pelo órgão regional competente; IV - facilitar o exercício da fiscalização pela autoridade competente." 
Nesse sentido, dispõe a NR-01 da Portaria 3.214/1978, que elenca as disposições gerais, que as Normas Regulamentadoras, relativas à segurança e medicina do trabalho, são de observância obrigatória pelas empresas privadas e públicas e pelos órgãos públicos da administração direta e indireta, bem como pelos órgãos dos Poderes Legislativo e Judiciário, que possuam empregados regidos pela CLT.

Não se deve olvidar da Lei 8.213/1991 (Lei de Benefícios da Previdência Social), que integra o sistema de reparação por acidentes do trabalho ao Regime Geral da Previdência Social, conferindo ao trabalhador direito às prestações (benefícios e serviços) decorrentes de infortúnio laboral. Em contrapartida, a lei impõe ao empregador a obrigação de recolher contribuições para custear os benefícios acidentários, contribuições variáveis conforme o grau de risco da atividade empresarial.

Este sistema de seguro compulsório por acidentes do trabalho, a cargo do INSS, não exime, entretanto, a responsabilidade civil do empregador e de terceiros causadores do infortúnio. A própria Carta Magna, como mencionamos, dispõe no artigo 7. ${ }^{\circ}$, inciso XXVIII, que o seguro contra acidentes do trabalho, a cargo do empregador, não exclui a indenização a que este está obrigado, quando incorrer em dolo ou culpa.

Como já aludimos, o meio ambiente de trabalho integra conceitual e normativamente o meio ambiente em geral. E, à luz do direito ambiental, lastreamo-nos no princípio do poluidor-pagador, do qual decorrem aspectos importantes para o aplicador do direito ambiental, como a responsabilidade civil objetiva, que já era prevista na Lei de Política Nacional do Meio Ambiente - Lei 6.938/1981, e foi recepcionada pela Constituição Federal de 1988 - aquele que não evita o dano responde objetivamente pelos prejuízos causados, conforme $\S 3 .^{\circ}$ do artigo 225 da Carta.

E pela definição legal contida no artigo $3 .^{\circ}$ da Lei de Política Nacional do Meio Ambiente, o conceito de poluição é plenamente aplicável ao meio ambiente do trabalho. Assim, quando o trabalho é exercido em um meio ambiente de trabalho degradado ou poluído, resta configurado que o empregador não cumpriu o papel social reservado à empresa, de acordo com os preceitos constitucionais; quando a empresa deixa de zelar pela segurança e saúde dos trabalhadores, descumpre obrigação determinada pela Constituição Federal, bem como viola exigência legal, desrespeitando seu papel social. 
E, embora no direito ambiental vigore o princípio da responsabilidade civil, não podemos reduzir o princípio do poluidor-pagador à reparação do dano, pois as sanções civis têm efeito preventivo, diante da probabilidade de ocorrência de um dano ao meio ambiente e, principalmente, porque as atividades poluidoras se apresentam lucrativas, seja pela possibilidade de não pagamento, seja pelo lucro líquido auferido com a atividade, ainda que seja determinada a obrigação de indenizar.

Sabe-se que, de acordo com a teoria do risco criado, quem empreende alguma atividade, lucrativa ou não, responde pelos danos causados a outrem. No entanto, cabe ponderar aqui que em determinadas condições laborais perversas a que é submetido o trabalhador, com exigência de níveis anormais de desgaste humano, de esforço físico ou psíquico desmesurado, o agente cria um risco em nível superior ao permitido, caracterizando-se o risco proibido ou um incremento do risco permitido. Nessas hipóteses, não se fala em relação de causalidade, e sim em imputação objetiva, à luz do ensinamento de Guilherme Guimarães Feliciano, anteriormente mencionado.

Trata-se, nessas situações, de risco proibido, eis que ninguém tem autorização legal para expor outrem a esforços tão exacerbados em condições de tal modo agressivas que possam até provocar a morte por exaustão.

Nessa linha, aplica-se a imputação objetiva para responsabilização do agente, e, em conformidade com os princípios do direito ambiental, como o princípio do poluidorpagador, o responsável deve arcar com a reparação dos danos da forma mais abrangente possível: tanto com a obrigação de não fazer, de se abster de expor os trabalhadores a idênticas condições nocivas, como de adoção de medidas protetivas à saúde e segurança no local de trabalho, e, além da responsabilização civil, já prevista na codificação civilista, impõe-se determinar que aquele que atingiu o nível do risco proibido deve sofrer uma cominação destinada a reparar os custos sociais, que são assumidos pela Seguridade Social.

Reitere-se, por aplicação analógica, o exemplo mencionado por Fábio Nusdeo, que se verifica em alguns países que estruturam cobranças tributárias destinadas a transferir recursos dos fabricantes de cigarro para os centros hospitalares onde estão internos os vitimados pelo tabaco, pela amônia, que é um produto destinado a aumentar a dependência, e outros subprodutos do tabagismo. 
Assim, se o agente, atuando na órbita do risco proibido, leva o trabalhador a óbito ou a limitações severas, deve arcar com ônus, que não deve ser assumido somente pela Previdência Social. Somente assim será atingida a internalização das externalidades negativas, para que estas não sejam, sempre, transferidas para toda a sociedade.

\subsection{Monetização do risco}

Como é sabido, e conforme exposto no capítulo anterior, no Brasil, o trabalho em condições insalubres e perigosas é remunerado com os respectivos adicionais, à guisa de compensar o maior desgaste do trabalhador.

A partir da análise do direito do trabalho comparado, Sebastião Geraldo de Oliveira observa que o legislador, diante dos agentes agressivos, adotou três estratégias: a) aumentar a remuneração do trabalhador, para compensá-lo pela exposição aos riscos - a chamada "monetização do risco"; b) proibição do trabalho; c) redução da jornada. E, de forma lúcida, expõe que a primeira alternativa é a mais cômoda e menos aceitável; a segunda hipótese é a ideal, porém nem sempre possível; e a terceira representa o ponto de equilíbrio, cada vez mais adotado. ${ }^{440}$

Nesse sentido, esse autor expõe que, tratando-se de trabalho com exposição a agentes insalubres, perigosos ou penosos, que propiciam desgastes acentuados à saúde, e em particular quando a eliminação do agente agressivo não é possível, a tendência moderna recomenda a redução da jornada de trabalho, isto é, a recomendação conjuga dois fatores benéficos: o menor tempo de exposição e maior período de descanso. ${ }^{441}$

Nessa linha, ilustra com o exemplo dos italianos, que no final dos anos 1960 iniciaram o movimento para melhoria das condições de saúde nos ambientes de trabalho, rejeitando a troca de saúde por dinheiro.

\footnotetext{
${ }^{440}$ OLIVEIRA, Sebastião Geraldo de. Proteção jurídica à saúde do trabalhador. São Paulo: LTr, 2010. p. 129.

${ }^{441}$ Idem, ibidem, p. 101.
} 
Michele Lepore e Anna Medina, ao tratarem do conceito de prevenção e da contribuição do movimento sindical na Itália, referindo-se aos anos 1969/1970, registram como patrimônio consolidado da experiência sindical, em matéria de prevenção, a recusa à monetização do risco e da nocividade, pois "saúde não se vende":

Anche sulle questioni della salute e della sicurezza in fabrica la línea sindacale evolve in maniera organica com l'impostazione politica generale. I presupposti su cui si è snodata questa línea sono ormai um patrimonio consolidato dall'ultimo decennio di storia dell'esperienza sindacale in materia di prevenzione:

a. il rifiuto della monetizzazione dei rischi e della nocività ("la salute non si vende");

b. na critica della presunta neutralità della scienza e immutabilità dell'organizzazione del lavoro - prodotti di uma particolare configurazione storica del capitale -, cui si contrappone l'esperienza operaia, volta al controllo e alla eliminazione contrattata dei fattori di danno alla integritá psicofisica dei lavoratori;

c. un cambiamento di strategia dell'uso degli strumenti legislativi e del rapporto con i poteri amministrativi e giudiziari, al fine di potenziare e consolidare le iniziative in difesa della salute ${ }^{442}$ (grifos nossos).

Observe-se que determinados autores optam por utilizar o termo "monetarização". Entendemos não ser apropriado ao tema em foco, dado que significa implementação de políticas financeiras, desenvolvimento das estruturas monetárias. ${ }^{443}$ A expressão aqui adotada é "monetização do risco", mais adequada ao objeto do nosso estudo, pois é o ato de transformar bens, metais, títulos, fatos, informações e acontecimentos em dinheiro. ${ }^{444}$

Sebastião Geraldo de Oliveira, lastreando-se nas lições de Diogo Pupo Nogueira, relembra que o primeiro caminho adotado foi o da recompensação financeira pela exposição aos agentes agressivos. Aqueles que defendiam tal medida justificavam que o pagamento tinha duas utilidades: por um lado, aumentaria o salário dos trabalhadores, o que permitiria que se alimentassem melhor, e isso propiciaria melhores condições de defesa do organismo; de outro lado, o pagamento constituiria em ônus para o empregador,

\footnotetext{
${ }^{442}$ LEPORE, Michele; MEDINA, Anna. Il diritto alla sicurezza sul lavoro. Roma: Lavoro, 1984. p. 28.

${ }^{443}$ Disponível em: <http://aulete.uol.com.br/>. Acesso em: 23 nov. 2012.

${ }^{444}$ De acordo com <http://www.dicionarioinformal.com.br>. Acesso em: 23 nov. 2012.
} 
que passaria a buscar a melhora das condições de trabalho, para se eximir de tal pagamento. $^{445}$

Os dois pressupostos mostraram-se falsos, pois estudos de Toxicologia do Trabalho comprovaram que uma alimentação balanceada e com elevado nível calorífico não influi na luta do organismo contra os agentes nocivos, que provocam eclosão de doença ocupacional.

O pagamento de adicionais pela exposição do trabalhador aos riscos, como corretamente afirma Sebastião Geraldo de Oliveira, desvia da preocupação central, que é a proteção à saúde do trabalhador. Por essa razão, a tendência trilhada já há algum tempo, em países da União Europeia e Canadá, para ilustrar, é eliminar os riscos para a saúde do trabalhador na sua origem, em vez de tentar neutralizá-los com equipamentos de proteção individual, bem como de "compensar" o obreiro exposto ao risco com adicionais.

Assim, no Canadá, a Lei de 21 de dezembro de 1979 é taxativa: “A presente lei tem por objetivo eliminar na raiz os problemas que ameacem a saúde, a segurança e a integridade física dos trabalhadores". 446

E a Diretiva 89/391 da União Europeia consagra como princípio geral de prevenção o combate dos riscos na origem. ${ }^{447}$

Saliente-se aqui que Sebastião Geraldo de Oliveira tece críticas também à previsão de concessão de aposentadoria especial para aqueles que trabalhassem 15, 20 ou 25 anos em serviços considerados penosos, insalubres ou perigosos, como previsto na Lei 3.807, de 26.06.1960, sustentando que tal diploma legal, a Lei Orgânica da Previdência Social, reforçou a monetização da exposição ao risco.

${ }^{445}$ OLIVEIRA, Sebastião Geraldo de. Proteção jurídica à saúde do trabalhador. 5. ed. São Paulo: LTr, 2010. p. 129.

${ }^{446}$ Idem, ibidem, p. 100.

447 “A presente directiva inclui princípios gerais relativos à prevenção dos riscos profissionais e à protecção da segurança e da saúde, à eliminação dos factores de risco e de acidente, à informação, à consulta, à participação, de acordo com as legislações e/ou práticas nacionais, à formação dos trabalhadores e seus representantes, assim como linhas gerais para a aplicação dos referidos princípios."

Disponível em: <http://eu-lex.europa.eu/LexUriServ/LexUriServ.do?uri=CELEX:31989L0391:pt: HTML>. Acesso em: 23 nov. 2012. 
Neste tópico, ousamos discordar, pois, como o próprio autor afirmou, e transcrevemos no início deste capítulo, a proibição do trabalho em condições adversas, seja insalubre, perigoso ou mesmo penoso, nem sempre é possível. E, como sustentamos no capítulo anterior, o trabalho penoso é aquele executado em situações-limite, em que não há medidas possíveis de controle ou de amenização, levando em conta o atual estágio das tecnologias e recursos disponíveis.

Aliás, nesse sentido pondera esse autor, afirmando que a opção de proibir o trabalho insalubre ou perigoso beira o radicalismo, a utopia. Ressalta que algumas atividades, mesmo perigosas ou prejudiciais, são imprescindíveis, e ilustra com o atendimento de paciente portador de doença contagiosa e o trabalho da coleta de lixo; diz que a proibição se restringe a casos especiais, como a vedação do trabalho insalubre ou periculoso do menor, como prevê o artigo 7., XXXIII, da Constituição Federal.

Por certo que o esforço possível e constante deve ser empreendido por todos, pelos estudiosos de todas as áreas do vasto campo da saúde do trabalhador, pelos poderes públicos, pelas entidades representativas dos trabalhadores, bem como pelos empregadores, na busca da eliminação das condições agressivas em que o trabalho é executado. No entanto, enquanto tal patamar ideal não é alcançado, determinados trabalhadores, que se dispuseram ou não tiveram outra alternativa ocupacional a não ser realizar atividades que exponham sua saúde ou integridade física aos riscos oriundos do trabalho, não podem ser tratados em pé de igualdade com aqueles que trabalham em um meio ambiente laboral saudável.

Entendemos que a aposentadoria especial se diferencia na essência dos adicionais que remuneram o trabalho exercido em condições de risco, na medida em que estes visam trocar a saúde por moeda, enquanto a aposentadoria especial permite que o trabalhador seja retirado mais cedo do trabalho. Tal benefício, sim, configura uma forma de compensação para aqueles obreiros que não tiveram outra opção laboral e aproxima-se da redução da jornada - esta retira o trabalhador mais cedo naquele dia e a aposentadoria especial o retira antecipadamente do trabalho depois de anos. Fica o registro para diferenciar esse benefício da monetização do risco; voltaremos ao tema um pouco mais adiante. 
É preciso refletir com equilíbrio, visando sempre à proteção do trabalhador; muitas vezes medidas radicais levam ao desemprego, que não é solução desejada por ninguém.

Nesse sentido, pondera Christiani Marques:

A monetarização do risco pode levar a crer que a saúde tem um preço quando realizado o pagamento de um adicional. Ressalta-se novamente que não se está dizendo ser o empregador o grande vilão da história da humanidade, pois existem inúmeras atividades que não possuem condições de eliminação total dos riscos gerados pelos agentes agressivos. Nessas hipóteses deve-se harmonizar o princípio fundamental da dignidade humana e a ordem econômica, para que a potencialidade do risco seja diminuída. O Texto Constitucional visa à garantia de direitos mínimos dos trabalhadores, no art. 7. ${ }^{\circ}$, por outro lado, fomenta a economia nacional, no art. 170, na iniciativa privada, com o lucro, desde que respeitada a condição digna do trabalho humano. Sendo assim, quando o legislador permite a atividade lucrativa ao empregador, crê que, em algumas atividades, não havendo a possibilidade de inexistência do risco diante das necessidades econômicas do Estado, este risco poderá ser potencialmente harmonizado com as garantias mínimas asseguradas ao trabalhador. Não se trata de vincular a pessoa humana como um objeto e tarifá-la. Nesse sentido, Ingo Wolfgang Sarlet alerta que, quando uma coisa tem preço, pode-se pôr, em vez dela, qualquer outra coisa como equivalente; mas quando ela está acima de todo o preço e, portanto, não permite equivalente, tem dignidade. ${ }^{448}$

E prossegue, manifestando-se contrariamente à implementação do adicional para atividades penosas:

Com a questão da monetarização do risco para o trabalho penoso, observa-se, nessa hipótese, que a fadiga constante e consequentemente a insegurança do trabalhador colocam em risco não só a própria vida, mas também o patrimônio das empresas e do Estado. Não se pode olvidar que algumas atividades existirão, mesmo que o empregador aplique todas as medidas de segurança do trabalho e higiene, ou seja, algumas atividades laborais são inerentes à própria economia. Sendo assim, não se pode fechar os olhos e aplicar a total negativa de flexibilização.

É claro que não se trata de algo que deva ser comum, mas sim de sua exceção, e o Direito não pode fugir è regulamentação. A regra é a indisponibilidade de tais direitos, porém, de forma excepcional, deve-se tratar a questão sem ferir o princípio da dignidade. ${ }^{449}$

\footnotetext{
${ }^{448}$ MARQUES, Christiani. A proteção ao trabalho penoso. São Paulo: LTr, 2007. p. 121.

${ }^{449}$ Idem, ibidem, p. 123.
} 
As decisões dos nossos Tribunais têm sido contrárias às pretensões de recebimento de adicional por atividades penosas, por falta de regulamentação na legislação ordinária; assim, a previsão constitucional, contida no artigo 7. ${ }^{\circ}$, XXIII, da Constituição Federal, é norma de eficácia limitada, a qual depende da atuação do legislador infraconstitucional para produzir efeitos. Como não foi regulamentado no âmbito infraconstitucional, não existe norma, não podendo ser deferido o aludido adicional. Nesse sentido, julgado da $12 .^{\text {a }}$ Turma do TRT da 2 a $^{\text {Região. }}{ }^{450}$

A Justiça do Trabalho só tem condenado as empresas a pagar tal compensação aos trabalhadores, caso haja previsão em convenção coletiva ou acordo coletivo de trabalho de determinada categoria.

Diante da constatação do desempenho de atividade penosa e em face da inexistência de previsão legal para concessão do respectivo adicional, alguns julgados dos nossos Tribunais têm determinado o pagamento de indenização por danos morais, em decorrência do exercício de tais atividades, como forma de, pedagogicamente, impulsionar o empregador a adotar medidas para neutralização das condições penosas de trabalho. Esse foi o entendimento adotado pela relatora, Desembargadora Ivani Contini Bramante, em julgado publicado em $2010 .^{451}$

Há registro de decisões que, por força das condições laborais adversas, acolheram a postulação do trabalhador, condenando o empregador ao pagamento do adicional de penosidade. No entanto, trata-se de entendimento minoritário, e o deferimento ocorreu porque havia previsão normativa de pagamento de acréscimo de 30\% sobre o salário-base, quando o trabalho, no caso do setor da construção civil, for realizado a uma alguma altura acima de três metros; por isso, é conveniente examinar as circunstâncias, quando houver o deferimento, a despeito da ausência da regulamentação legal. ${ }^{452}$

${ }^{450}$ Rel. Des. Francisco Ferreira Jorge Neto, Acórdão 20120476155, Proc. 20120004175, DJ 04.05.2012. Disponível em: $<\mathrm{http}: / / w w w . t r t s p . j u s . b r>$. Acesso em: 24 nov. 2012.

${ }^{451}$ Rel. Des. Ivani Contini Bramante, Acórdão 20100179805, Proc. 00192-2008-062-02-00-5, DJ 19.03.2010. Disponível em: <http://www.trtsp.jus.br>. Acesso em: 24 nov. 2012.

${ }^{452}$ A 2. ${ }^{a}$ Vara do Trabalho de Pouso Alegre recebeu a ação trabalhista ajuizada por um servente de pedreiro contra uma construtora, na qual ele postulava a condenação da empresa ao pagamento do adicional de penosidade. Examinando a convenção coletiva de trabalho da categoria, a Juíza Rita de Cássia Barquette 
E, na falta de regulamentação na legislação ordinária, quando houver pagamento de adicional por atividades penosas, por força de norma coletiva, por exemplo, há possibilidade de cumulação com os adicionais de insalubridade ou de periculosidade, por não haver vedação legal e por remunerarem situações distintas, conforme entendeu o Colendo Tribunal Superior do Trabalho. ${ }^{453}$

Contudo, a regulamentação da previsão constitucional, com a instituição do pagamento de mais um adicional, o de penosidade, não vai servir de freio à exposição do trabalhador às condições nocivas e adversas no meio ambiente de trabalho. Ainda que haja previsão legal de remuneração desse adicional com base no salário contratual, como é o de periculosidade, isso não afeta os detentores do capital e das forças produtivas, pois sempre é mais barato deixar de investir em equipamentos, em novas tecnologias para melhoria das condições laborais, para pagar adicionais aos trabalhadores, como já ocorre com o trabalho periculoso e com o insalubre. Quanto a este, observe-se que ainda persiste a polêmica se os percentuais de $10 \%, 20 \%$ ou de $40 \%$ incidem sobre o salário contratual ou sobre o salário mínimo, sendo majoritário o entendimento dos nossos Tribunais de adoção da segunda hipótese: é um valor ínfimo para pagar o trabalho com exposição aos agentes agressivos. De qualquer forma, mesmo que os adicionais estivessem em patamar remuneratório mais elevado, trata-se ainda de um preço muito barato para a compra da saúde do trabalhador.

\footnotetext{
Nascimento, titular da Vara, verificou que a cláusula $6 .^{\text {a }}$ estabelece que os empregados que trabalham em "balancim" ou serviços externos realizados a uma altura acima de 3 metros terão um acréscimo de $30 \%$ sobre o valor do salário-base. Uma testemunha indicada pela construtora confirmou que o reclamante trabalhava junto aos pedreiros e carpinteiros e ajudava a levar o material para os andares superiores, auxiliando os oficiais na entrega das ferragens e ajudando os armadores na montagem das lajes. Segundo informações da testemunha, o reclamante já trabalhou em altura superior a 20 metros.
}

Nesse contexto, a magistrada reconheceu o direito do trabalhador de receber o adicional de penosidade, entendendo que ficou comprovada a realização de serviços externos a uma altura acima de 3 metros, sendo que sua atribuição como servente, era ajudar os oficiais e armadores na montagem das lajes dos andares superiores. Assim, acolhendo o pedido do trabalhador, a juíza sentenciante condenou a construtora ao pagamento do adicional de penosidade, à razão de $30 \%$ do salário base. Disponível em: $<$ http://www.fontedodireito.com.br/trabalhista/construtora-e-condenada-a-pagar-adicional-de-penosidadea-servente-de-pedreiro>. Acesso em: 24 nov. 2012.

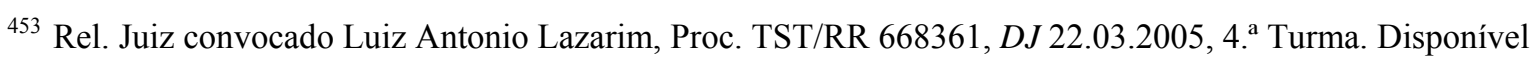
em: <http://www.tst.jus.br>. Acesso em: 24 nov. 2012.

Nesse mesmo sentido o julgado: Proc. RR 561838, 5. a Turma, Rel. Min. João Batista Brito Pereira.

Disponível em: <http://jus.com.br/revista/texto/14779/adicional-de-penosidade\#ixzz2D5X1Ox2j>. Acesso em: 24 nov. 2012. 
Sem sombra de dúvida, o caminho a ser trilhado é o da tendência moderna, que converge para a redução da jornada nos trabalhos exercidos em condições adversas, conjugada com a melhoria contínua no ambiente de trabalho. Esta seria a alternativa viável, além da possibilidade de o trabalhador retirar-se mais cedo do trabalho, com a obtenção de aposentadoria especial, como se verá.

Por tudo isso, impõe-se prever a efetiva reparação social, pelos desgastes provocados pelo trabalho desempenhado em condições perversas, de acordo com as ideias alinhavadas no início deste tópico, que serão aprofundadas ao final.

\subsubsection{Projetos de lei}

Como já foi dito, o artigo 7. ${ }^{\circ}$, XXIII, da Constituição Federal de 1988 previu a concessão de adicional de remuneração para as atividades penosas, insalubres ou perigosas, "na forma da lei”. Trata-se de norma constitucional de eficácia limitada, pois depende da atuação do legislador infraconstitucional para regulamentá-la e para produzir efeitos.

Por essa razão, a busca pela conceituação de "trabalho penoso" e pela sua regulamentação intensificou-se a partir do advento da Carta de 1988, como se constata pelos diversos projetos de lei que já tramitaram e ainda tramitam pelo Congresso Nacional. De acordo com Christiani Marques, a Câmara dos Deputados tem registros, desde 1973, de vários projetos de lei que tratam de algumas atividades como penosas, tendo sido apresentadas mais de 60 proposituras; alguns foram arquivados, outros se encontram em trâmite. $^{454}$

Um dos projetos de lei que se encontra em tramitação é o de n. 1.015/1988, de iniciativa do Deputado Federal Paulo Paim, que traz no artigo $1 .^{\circ}$ o conceito de atividade penosa:

Serão consideradas atividades penosas aquelas que, por sua natureza, condições ou métodos de trabalho, exijam dos empregados esforço e condicionamento físicos, concentração excessiva, atenção permanente, isolamento e imutabilidade da tarefa desempenhada em níveis acima dos

${ }^{454}$ MARQUES, Christiani. A proteção ao trabalho penoso. São Paulo: LTr, 2007. p. 62. 
limites de tolerância fixados em razão da natureza e da intensidade do trabalho a que estão submetidos. ${ }^{455}$

Outra propositura de iniciativa do Deputado Paulo Paim, o Projeto de Lei 1.171/1999, que altera dispositivos da CLT para dispor sobre atividades penosas, adicional de penosidade e dá outras providências, foi apensado ao 2.774/1997 e arquivado, por decisão da Mesa Diretora da Câmara, em 16.03.2000.

De mesma autoria, o Projeto de Lei 7.083/2002 define as atividades de motoristas e cobradores de transportes coletivos urbanos como penosas, conceituando estas como "aquelas que, por sua natureza, condições ou métodos de trabalho, expõem os empregados a condições de estresse e sofrimento físico e mental". 456

Tramita na Câmara o Projeto de Lei 611/2011, do Deputado Onofre Santo Agostini (DEM-SC), que regulamenta a profissão de motorista de ambulância. Pela proposta, poderá receber essa qualificação profissional quem trabalhar no transporte de pacientes que tenham como origem ou destino hospitais, clínicas, postos de saúde ou unidades de pronto atendimento (UPA); o projeto garante à atividade o adicional de penosidade, caso o profissional não receba adicional de insalubridade ou periculosidade. A atividade penosa é definida como aquela que provoca grande desgaste físico e psicológico e gere dano à saúde e que não esteja prevista nas atividades insalubres ou perigosas.

Ressalte-se que nessas proposituras foram adotados variados conceitos, por exemplo, o contido no Projeto de Lei 4.243/2008, de autoria do Deputado Federal Maurício Rands:

Art. 196-A. Considera-se penoso o trabalho exercido em condições que exijam do trabalhador esforço físico, mental ou emocional superior ao despendido normalmente, nas mesmas circunstâncias, ou que, pela postura ou atitude exigida para seu desempenho, sejam prejudiciais à saúde física, mental e emocional do trabalhador. $[\ldots]^{457}$

\footnotetext{
${ }^{455}$ Tal propositura está aguardando, desde 29.10.1992, ser submetida à apreciação do Plenário; tramita em conjunto com o Projeto de Lei 1.003/1988 e foi apensada ao Projeto de Lei 2.549/1992.

${ }^{456}$ O PL aguarda, desde 26.08.2002, apreciação pelo Plenário; tramita em conjunto com o Projeto de Lei $1.113 / 1988$.

${ }^{457}$ Este Projeto de Lei foi apensado ao PL 2.542/1992, que tem anexados outros 27 projetos de lei.
} 
O Projeto de Lei 552, de 2009, da Senadora Serys Slhessarenko, em trâmite no Senado Federal, regulamenta as atividades exercidas por trabalhadores sob radiação solar a céu aberto, as quais serão consideradas penosas e, quando sem a proteção adequada, insalubres. O trabalho exercido nessas condições poderá acarretar o pagamento do adicional de penosidade, no valor de $30 \%$ sobre o salário-base do trabalhador. ${ }^{458}$

Diz Leny Sato que os projetos de lei, até hoje não aprovados, tentam conceituar "trabalho penoso", associando esta categoria de trabalho a esforço físico ou mental. O esforço mental, explica, aproxima-se do esforço cognitivo, havendo apenas um dos projetos de lei, o de n. 2.168/1989, que, por meio da palavra "stress", apontava para a existência de repercussões emocionais. Ocorre que tal propositura foi apensada ao Projeto de Lei 1.015/1988; este foi apensado ao Projeto de Lei 2.549/1992, que por sua vez dá nova redação ao artigo 192 da CLT, cuida somente do adicional de insalubridade e ainda aguarda votação em plenário.

Percebe-se que não há vontade política em regulamentar o trabalho penoso, caso contrário, tal regulamentação já estaria em vigor. Tal circunstância denota também a dificuldade existente em relação à matéria; tanto é assim que a maioria das proposituras que institui o adicional por atividades penosas escapa da conceituação de "trabalho penoso". Dentre as exceções encontram-se os projetos de lei apresentados pelo Deputado Federal Paulo Paim, como citamos.

Cumpre salientar que a ausência de conceituação de "atividade penosa", na nossa legislação, é a regra, conforme foi dito. No entanto, o Decreto 4.307/1994 do Estado de Santa Catarina pode ser apontado como exceção, pois dispõe que por atividades consideradas penosas entende-se: "o trabalho árduo, difícil, molesto, trabalhoso, incômodo, doloroso, rude e que exige a atenção constante e vigilância acima do comum", como consta do inciso I, $\S 1 .^{\circ}$, do artigo 1.. ${ }^{459}$

Reitere-se, contudo, que o pagamento de adicionais traz uma falsa percepção, de um lado, para o trabalhador, de que está usufruindo de um direito, e, de outro, para o

\footnotetext{
${ }^{458}$ Em 02.06.2011 foi aprovado Parecer contrário ao Projeto de Lei 552/2009, da Comissão de Agricultura e Reforma Agrária do Senado Federal.

${ }^{459}$ MARQUES, Christiani. A proteção ao trabalho penoso. São Paulo: LTr, 2007. p. 191.
} 
empregador, ao concedê-lo, é como se cumprisse uma obrigação, desonerando-se de implementar as medidas que efetivamente assegurem a melhoria das condições de trabalho.

\subsubsection{Exemplos de categorias que recebem o adicional de penosidade}

A título ilustrativo, seguem alguns exemplos de categorias de trabalhadores que recebem o adicional de penosidade.

Há legislação específica para determinadas categorias prevendo o pagamento desse adicional, como ocorre com os servidores públicos civis da União, das autarquias e das fundações públicas federais, que têm direito a essa remuneração, conforme previsão da Lei 8.112/1990 (art. 71); assim, fazem jus ao adicional de atividade penosa aqueles que exercem suas funções em zonas de fronteira ou em localidades "cujas condições de vida o justifiquem", nos termos e condições a serem estabelecidos em regulamento, que não houve. Tanto é assim que os servidores do Poder Judiciário Federal, que atuam em regiões que fazem fronteira com outros países, reivindicam o pagamento do adicional de penosidade e não obtiveram deferimento, pois o pedido depende de parecer técnico de acordo com o Conselho Superior da Justiça do Trabalho, conforme resposta à Federação dos Servidores. ${ }^{460}$

${ }^{460} \mathrm{O}$ processo da Fenajufe que reivindica o pagamento do adicional de penosidade aos servidores do Judiciário Federal, com foco nos que atuam em regiões que fazem fronteira com outros países, tramita com o número CF-PPN-2012/00017 e encontra-se em fase de análise pelas áreas técnicas do Conselho.

O pedido, protocolado pela Federação no dia 24 de fevereiro de 2011 no CJF, e também no CSJT, TSE e STM, abrange os servidores da Justiça Federal e tramitava com o número inicial de 2011160752.

\section{Tramitação nos outros órgãos}

Os processos em questão foram protolocados pela Fenajufe no CSJT [Conselho Superior da Justiça do Trabalho], CJF [Conselho da Justiça Federal], TSE e STM no dia 24 de fevereiro de 2011. No documento, a Federação solicita que os tribunais superiores e os conselhos baixem "ato regulamentar necessário ao início do pagamento do adicional de atividade penosa de que tratam os artigos 70 e 71 da Lei 8.112/1990, relativamente aos servidores do Poder Judiciário da União", utilizando como precedente regulamentação editada pelo MPU.

Em abril, a Assessoria Jurídica da Fenajufe obteve a informação de que no CSJT o pedido de providência 1362-32.2011.5.90.0000 foi negado, sob a alegação de que competência para apreciação caberia ao CNJ. Provocado, o Conselho Nacional de Justiça argumentou que não poderia deliberar sobre o assunto antes de decisão dos Conselhos ou Tribunais. Diante desse entendimento, a Fenajufe apresentou um novo pedido junto ao CSJT no dia 28 de junho do ano passado, que recebeu o número PP 425411.2011.5.90.0000 e tem como relatora a Conselheira Maria Cristina Irigoyen Peduzzi. Segundo o levantamento da Assessoria Jurídica Nacional, o pedido aguarda pareceres técnicos.

Disponível em: <http://www.sindjuf-paap.org.br>. Acesso em: 25 nov. 2012. 
A Lei 11.890 , de 24 de dezembro de 2008, é outra norma voltada aos servidores públicos federais; dispõe sobre a reestruturação da composição remuneratória das Carreiras de Auditoria da Receita Federal do Brasil e Auditoria-Fiscal do Trabalho e de outras e prevê pagamento de adicional para atividades insalubres, perigosas ou penosas.

Assim, o adicional para remuneração do exercício nas atividades tidas como penosas, na falta de previsão legal geral, é concedido por meio de determinados acordos e convenções coletivas de trabalho. E o Poder Judiciário só tem condenado empresas a pagar essa compensação aos trabalhadores, quando há previsão em norma coletiva.

O Sindicato dos Urbanitários do Distrito Federal, por exemplo, previu em acordo coletivo de trabalho, em atendimento ao artigo $7 .^{\circ}$, inciso XXIII, da Constituição Federal, o pagamento do Adicional de Penosidade aos empregados submetidos ao regime de turno ininterrupto em escala de revezamento. ${ }^{461}$

Com efeito, o adicional tem sido concedido com mais frequência por companhias que mantêm empregados trabalhando em turnos ininterruptos de revezamento, comum nas plataformas de petróleo, refinarias e siderúrgicas, como forma de compensação ao empregado que não consegue manter os mesmos horários livres.

Outra categoria que já obteve o direito a esse acréscimo foi a dos motoristas de ônibus, por força de acordo coletivo de trabalho firmado entre o Sindicato dos Trabalhadores em Transporte Rodoviário de Caxias do Sul (RS) e uma empresa do setor; o adicional fixado foi de $10 \%$ do salário mínimo na proporção dos dias efetivamente trabalhados. O Sindicato da Construção Civil do Tocantins celebrou acordo com as empresas locais, prevendo o pagamento do adicional de penosidade em $20 \%$ do salário para todos os empregados, inclusive serventes, quando o trabalhador tiver de permanecer suspenso em balancins, ${ }^{462}$ a exemplo dos trabalhadores na construção civil de Pouso Alegre, MG, conforme decisão anteriormente mencionada.

${ }^{461}$ Disponível em: < http://www.urbanitariosdf.org.br/>. Acordo Coletivo de Trabalho 2006/2007. Acesso em: 24 nov. 2012.

${ }^{462}$ Disponível em: $<$ http://www.senado.gov.br/noticias/OpiniaoPublica/inc/senamidia/notSenamidia.asp?ud= $20110215 \&$ datNoticia $=20110215 \& \operatorname{codNoticia}=519646 \&$ nomeOrgao $=$ \&nomeJornal $=$ Valor + Econ $\% \mathrm{C} 3 \%$ B4mico\&codOrgao=2729\&tipPagina $=1>$. Acesso em: 15 fev. 2011. 
De todo modo, verifica-se que a remuneração pelo labor prestado em condições de penosidade, por meio do adicional respectivo, ocorre de forma esparsa, para determinadas categorias profissionais cujas normas coletivas preveem o pagamento dessa compensação.

E quando o adicional de atividade penosa é previsto em lei, caso dos servidores públicos federais, a norma ainda não foi regulamentada e, por essa razão, efetivamente não há o pagamento.

Vejamos a seguir, quando, em decorrência de condições adversas no meio ambiente de trabalho, ocorrem os acidentes e eclodem as doenças do trabalho, e o trabalhador é obrigado a se afastar de suas atividades laborativas, a se submeter a tratamento médico, e é encaminhado ao Segurador Oficial, qual é o atendimento prestado pela Seguridade Social, quais os benefícios a que faz jus o segurado e como vem sendo prestado tal atendimento.

\subsection{A reparação dos danos pela Previdência Social. Avanços e retrocessos da legislação acidentária no Brasil}

A previdência social está inserida no rol dos direitos humanos sociais consignados no artigo $6 .^{\circ}$ da Constituição Federal. A Carta de 1988 trouxe novo e ampliado conceito de Seguridade Social, estabelecendo no artigo 194 que esta compreende um conjunto integrado de ações de iniciativa dos Poderes Públicos e da sociedade, destinados a assegurar os direitos relativos à saúde, à previdência e à assistência social.

Data de tempos remotos a preocupação com a previdência social, especialmente com o infortúnio. Teve evolução marcante na legislação estrangeira, inicialmente na Europa, com avanço na Alemanha e na Inglaterra. Na Constituição do México, de 1917, e de Weimar, de 1919, na Alemanha, a Previdência passou a receber tratamento em sede constitucional, indicando seu fortalecimento e fundamentalidade para a segurança da sociedade contra as investidas revogatórias do legislador ordinário. ${ }^{463}$

${ }^{463}$ PINTO, Airton Pereira. Direito do trabalho, direitos humanos sociais e a Constituição Federal. São Paulo: LTr, 2006. p. 210-211. 
A OIT tem demonstrado a seus países-membros, por meio de várias Convenções, a necessidade da proteção social ao homem que trabalha: logo no início da criação da Organização, em 1923, entrou em vigor no plano internacional a Convenção 12, que trata da indenização por acidente do trabalho na agricultura. ${ }^{464}$

A Convenção 102, em vigor desde 1955, consagrou no plano internacional conceito mais amplo, o de seguridade social, propondo contemplação de várias coberturas; não foi ratificada pelo Brasil. No entanto, há semelhança entre as normas da Constituição Federal e as disposições dessa Convenção, que prevê, entre outros, serviços de assistência médica, prestações monetárias por força de enfermidades; prestações de velhice; prestações de acidentes do trabalho ou moléstias profissionais; prestações de maternidade; prestações de invalidez; pensão por morte. ${ }^{465}$

Ninguém contesta que o Brasil é um dos países do mundo onde mais ocorrem acidentes do trabalho; atualmente é o quarto no ranking mundial, registrando mais de 700 mil acidentes de trabalho por ano, e gastos da ordem de 70 bilhões com pagamentos de benefícios e pensões. ${ }^{466}$

Além do grande prejuízo sofrido pelos empregados que são mutilados, morrem ou ficam inválidos ou ainda passam a sofrer de moléstia incapacitante, também a economia do País é onerada, sobretudo a Previdência Social, que finalmente paga os auxílios-doença, aposentadorias e pensões.

O caminho, na busca de solução adequada para problema de tamanha complexidade, passa, como já dissemos, pela participação dos trabalhadores e suas entidades representativas nos locais de trabalho; pela conscientização de todos, em particular dos empregadores, que precisam investir em prevenção, para adequação do meio ambiente do trabalho a níveis razoáveis de salubridade e segurança, pois custa muito menos para todos evitar os infortúnios do que assumir seus custos.

\footnotetext{
464 SÜSSEKIND, Arnaldo. Convenções da OIT. São Paulo: LTr, 1998. p. 84.

${ }^{465}$ PINTO, Airton Pereira. Direito do trabalho, direitos humanos sociais e a Constituição Federal. São Paulo: LTr, 2006. p. 211.

${ }^{466}$ Divulgação de 13 set. 2012. Sindicato Nacional dos Auditores Fiscais do Trabalho. Disponível em: $<$ http://www.sinait.org.br/noticias_ver.php?id=6162>. Acesso em: 5 dez. 2012.
} 
Quando falha a prevenção, eclodem as doenças e ocorrem os acidentes do trabalho, cumpre promover as coberturas necessárias à garantia da sociedade, por meio do sistema que abrange, como dissemos, saúde, previdência social e assistência social.

São três regimes distintos: a) o Regime Geral de Previdência Social, que abrange os trabalhadores do setor privado, empregados, avulsos e autônomos; e no setor público, compreende os servidores celetistas e os ocupantes de cargos exclusivamente em comissão; b) Regime Próprio de Previdência dos Servidores: regime do servidor da União, dos Estados, do Distrito Federal e dos Municípios e o regime próprio dos militares; c) o regime de Previdência Complementar.

Trataremos aqui do Regime Geral da Previdência Social e dos benefícios prestados pelo Instituto de Seguridade Social, o INSS, pois os demais regimes são muito específicos.

Da consulta ao sítio do Ministério da Previdência Social infere-se que a definição oficial de Previdência Social é:

[...] um seguro que garante a renda do contribuinte e de sua família, em casos de doença, acidente, gravidez, prisão, morte e velhice. Oferece vários benefícios que juntos garantem tranquilidade quanto ao presente $\mathrm{e}$ em relação ao futuro assegurando um rendimento seguro. ${ }^{467}$

Constata-se que essa conceituação caminha pela trilha de que previdência é um "seguro", e corresponde ao pagamento de benefícios, voltados a assegurar a manutenção da renda, em caso de doença, acidente, entre outros, que de alguma forma tenham afetado a capacidade laborativa do trabalhador; assim, a "previdência social garante a renda do contribuinte".

Observa-se que aqui está inserido o princípio contributivo, isto é, há proteção previdenciária desde que haja contribuição. O financiamento da seguridade social será efetuado por toda a sociedade, de forma direta e indireta, nos termos do artigo 195 da Constituição Federal, que estipula que os recursos serão provenientes dos orçamentos da União, dos Estados, do Distrito Federal e dos Municípios, bem como das contribuições

${ }^{467}$ Disponível em: <http://www.mpas.gov.br>. Acesso em: 27 nov. 2012. 
sociais do empregador (incidentes sobre: folha de salários e demais rendimentos do trabalho; a receita ou faturamento; o lucro); do trabalhador e dos demais segurados da Previdência Social, não incidindo sobre aposentadoria e pensão concedidas pelo regime geral; receita de concurso de prognósticos; do importador de bens ou serviços do exterior.

É preciso retornar à amplitude dada pela Carta de 1998 à Seguridade Social, abrangendo saúde, previdência e assistência social.

E, para assegurar tais direitos, previstos constitucionalmente, prevê a Lei 8.212, de 24 de julho de 1991, que dispõe sobre a organização da Seguridade Social e institui Plano de Custeio, que ela obedecerá aos seguintes princípios e diretrizes: a) universalidade da cobertura e do atendimento; b) uniformidade e equivalência dos benefícios e serviços às populações urbanas e rurais; c) seletividade e distributividade na prestação dos benefícios e serviços; d) irredutibilidade do valor dos benefícios; e) equidade na forma de participação no custeio; f) diversidade da base de financiamento; g) caráter democrático e descentralizado da gestão administrativa com a participação da comunidade, em especial de trabalhadores, empresários e aposentados.

Esse diploma legal define saúde como "direito de todos e dever do Estado, garantido mediante políticas sociais e econômicas que visem à redução do risco de doença e de outros agravos e ao acesso universal e igualitário às ações e serviços para sua promoção, proteção e recuperação", nos termos do seu artigo 2. ${ }^{\circ}$, assegurando no seu parágrafo único e alíneas acesso universal e igualitário.

E, por seu turno, conforme artigo $4 .^{\circ}$ da Lei 8.212/1991, assistência social é a política social que provê o atendimento das necessidades básicas, traduzidas em proteção à família, à maternidade, à infância, à adolescência, à velhice e à pessoa portadora de deficiência, independentemente de contribuição à Seguridade Social.

Por meio do Regime Geral da Previdência Social são concedidos os seguintes benefícios e serviços, de acordo com o artigo 18 da Lei 8.213/1991: I - quanto ao segurado: a) aposentadoria por invalidez; b) aposentadoria por idade; c) aposentadoria por tempo de contribuição; d) aposentadoria especial; e) auxílio-doença; f) salário-família; g) salário-maternidade; h) auxílio-acidente; II - quanto ao dependente: a) pensão por morte; 
b) auxílio-reclusão; III - quanto ao segurado e dependente: a) serviço social; b) reabilitação profissional.

Elencados os benefícios e serviços a que faz jus o segurado, cumpre apontar como efetivamente ocorre a prestação de benefícios pela Previdência Social, não de todos, o que tornaria este estudo exaustivo e distanciado do seu objeto, mas de alguns, que afetam em particular os trabalhadores acidentados no trabalho ou acometidos de doenças de origem ocupacional.

Iniciemos pela perícia médica, momento crucial para o trabalhador, quando se submete ao exame médico realizado por perito credenciado pelo INSS. De longa data registram-se queixas acerca da forma com que a perícia é realizada: desde posturas apriorísticas contrárias ao acidentado, com conclusões médico-periciais de descaracterização do nexo de causalidade entre acidente ou doença e as atividades laborativas e diagnóstico de moléstia degenerativa; passando por atitudes de descaso e desrespeito por parte dos peritos, em relação aos acidentados no trabalho, que muitas vezes sequer são examinados. Existem queixas de que o perito não faz exame clínico, não toca o segurado; há ocasiões em que sequer analisa os exames médicos realizados pelo periciando. Ressalte-se que a população atendida é composta, na sua maioria, por indivíduos humildes, muitas vezes semialfabetizados e que, mesmo sentindo-se humilhados, não conseguem ou têm receio de reagir contra este tipo de comportamento do médico.

Os problemas com a perícia médica realizada pelo INSS são tão reiterados e de tão longa data que se pode dizer que este modelo está falido. Com o objetivo de alterar esta situação e implementar uma política de saúde e segurança no trabalho que foque a prevenção e reabilitação física e profissional do trabalhador, foi constituído o "Grupo de Trabalho responsável pela avaliação e proposição de Políticas de Saúde e Segurança no trabalho", por meio da Portaria Interministerial 323, de 11 de julho de 2012, dos Ministérios da Previdência Social; Trabalho e Emprego; Saúde e Planejamento, Orçamento e Gestão, com as seguintes atribuições:

I - avaliar, numa visão integrada, a evolução das políticas de saúde e segurança no trabalho; 
II - propor a reformulação do modelo de avaliação médico pericial do Instituto Nacional do Seguro Social - INSS, no âmbito de uma política de saúde e segurança no trabalho que foque a prevenção e reabilitação física e profissional do trabalhador;

III - elaborar proposta de plano integrado de habilitação e reabilitação física e profissional, englobando custeio e benefícios;

IV - propor otimizações nas políticas públicas em defesa do meio ambiente adequado de trabalho e da saúde do trabalhador. ${ }^{468}$

A reformulação do modelo de avaliação médico-pericial do INSS é aguardada; essa alteração necessariamente também exige uma seleção criteriosa dos peritos; o profissional que desempenha tal função não pode ter uma concepção preconceituosa em relação ao trabalhador. Por outro lado, cabem críticas aos médicos avaliadores que adotam postura paternalista, concedendo benefícios sem quaisquer critérios. Muitas vezes há uma inversão: quem necessita não obtém a concessão do benefício, enquanto determinados segurados, mesmo em situações de inexistência de incapacidade, têm deferida a concessão. Como qualquer servidor público, o perito precisa ter consciência da importância do papel que desempenha, de que os benefícios concedidos advêm dos cofres públicos, ainda que custeados em parte pela sociedade. E, primordialmente, esse profissional deve ter um olhar despido de preconceito em relação ao trabalhador; mais que isso, deve compreender a realidade social e ter sensibilidade, de maneira a exercer seu papel com visão mais abrangente e comprometida com uma política de saúde e segurança no trabalho, com foco na prevenção e na reabilitação física e profissional do trabalhador.

E no que diz respeito à reabilitação profissional, ensinam Maria Maeno e Rodolfo Andrade de Gouveia Vilela que a reabilitação da capacidade funcional do trabalhador está presente na legislação previdenciária desde 1944; inicialmente era citada como "readaptação profissional" e "reaproveitamento do empregado acidentado" e tinha como objeto restituir, parcial ou totalmente, a todo incapacitado para o trabalho, a "capacidade na primitiva profissão ou em outra compatível com as suas novas condições físicas". ${ }^{4}$

\footnotetext{
${ }^{468}$ Portaria Interministerial 323, de 11.07.2012. Diário Oficial da União, 12.07.2012, p. 67.

${ }^{469}$ MAENO, Maria; VILELA, Rodolfo Andrade de Gouveia. Reabilitação profissional no Brasil: elementos para a construção de uma política pública. Revista Brasileira de Saúde Ocupacional, São Paulo, p. 88, 2010.
} 
A partir de 1976 a legislação tornou obrigatória a readaptação profissional nos casos de acidentes do trabalho, como um direito do acidentado.

$\mathrm{Na}$ legislação atual ampliou-se o direito à reabilitação profissional ao dependente, além do segurado, acidentado do trabalho ou não, e se determinou que o segurado, em gozo de auxílio-doença (benefício temporário por incapacidade), impossibilitado de recuperação para sua atividade habitual, “deverá submeter-se ao processo de reabilitação profissional para o exercício de outra atividade", ressaltam Maria Maeno e Rodolfo Vilela. $^{470}$

Esses autores explicam que na década de 1990, com o aumento do número de segurados com restrições decorrentes de doenças de origem ocupacional, especialmente de Lesões por esforço repetitivo/Lesões por Esforços Repetitivos ou Distúrbios Osteomusculares Relacionados ao Trabalho (LER/DORT), os procedimentos adotados pelos Centros de Reabilitação Profissional (CRP) e pelos Núcleos de Reabilitação (NRP) evidenciaram a sua insuficiência, pois estavam habituados e estruturados para o atendimento de acidentados do trabalho; tal clientela passou a coexistir com outras, com restrições pouco visíveis, como doenças de evolução crônica e de distúrbios psíquicos, normalmente oriundos de empresas com grande número de ocorrências, com condições de trabalho inalteradas, sem adoção de qualquer medida preventiva.

E, para fins didáticos, Maeno e Vilela identificam três fases no processo de mudança da reabilitação profissional do INSS, desde a Constituição de 1988: na primeira fase, concomitantemente à emergência de movimentos sociais e à implementação do SUS, entre 1993 a 1994, surgiram questionamentos aos modelos estruturais centralizados e aos conceitos que consideravam a incapacidade diretamente relacionada à doença ou ao trauma, que exigia essencialmente a assistência médica individual; a segunda fase, de 1995 a 2000, simbolizada pelo Plano de Modernização da Reabilitação Profissional do INSS, consolidou a hegemonia do modelo reducionista da atenção, de delegação da administração da reinserção ao trabalho nas empresas, e o desmonte dos CRP e dos NRP, já em fase de decadência, conforme mencionado. E embora não tenha ocorrido no Brasil a privatização

\footnotetext{
${ }^{470}$ MAENO, Maria; VILELA, Rodolfo Andrade de Gouveia. Reabilitação profissional no Brasil: elementos para a construção de uma política pública. Revista Brasileira de Saúde Ocupacional, São Paulo, p. 89, 2010.
} 
da Previdência Social, como ocorreu em vários países da América Latina, os procedimentos adotados internamente na autarquia nas últimas duas décadas, por meio de ordens internas, evidenciam o foco na interpretação da legislação com foco na redução de custos, com distanciamento da previsão legal, como destacam:

Não estabelecimento de nexo, não concessão de benefícios, não informação dos direitos do segurado, a negativa da CAT (se não emitida pelo médico da empresa), vinculando-as à avaliação de qualidade e do desempenho da atividade pericial. ${ }^{471}$

Prossegue, relatando que a terceira fase de mudanças na Reabilitação Profissional foi a da implementação do Projeto Reabilita, iniciada em 2001 e ainda vigente nos dias atuais, fundamentada no regulamento da Previdência Social; sua característica principal tem sido de transferir o processo de recolocação sob a responsabilidade institucional de orientadores profissionais, e não mais de equipes de reabilitação profissional.

Maria Maeno e Rodolfo Vilela descrevem os problemas crônicos da reabilitação profissional:

[...] a sua descaracterização como um serviço previdenciário; a inexistência de uma avaliação multiprofissional; a delegação da responsabilidade do estágio probatório à empresa, sem qualquer análise sobre a compatibilidade do estado de saúde e a funcionalidade do reabilitando com as atividades laborais propostas; a finalização da "reabilitação profissional" mesmo com os desempenhos insatisfatórios dos reabilitandos, cessando-lhes o benefício por incapacidade.

As possibilidades dos segurados serem ouvidos no tocante às exigências das atividades laborais, à qualidade do acolhimento por parte das chefias e dos colegas são nulas, sendo-lhes negada a possibilidade de serem sujeitos de sua reabilitação profissional. ${ }^{472}$

Além de todos esses aspectos, o enfoque utilizado pelos peritos médicos para avaliar as consequências de acidentes e doenças - a incapacidade -, desde há algum tempo, já não é o adotado em países da Europa e nos Estados Unidos, que fazem uso da Classificação Internacional de Funcionalidade, Incapacidade e Saúde, a CIF. Trata-se de

\footnotetext{
${ }^{471}$ MAENO, Maria; VILELA, Rodolfo Andrade de Gouveia. Reabilitação profissional no Brasil: elementos para a construção de uma política pública. Revista Brasileira de Saúde Ocupacional, São Paulo, p. 90, 2010.

${ }^{472}$ Idem, ibidem.
} 
um novo instrumento da Organização Mundial de Saúde (OMS) para a mensuração de condições relacionadas à saúde.

Como relata Cassia Maria Buchalla, há algum tempo, particularmente desde 1972, a OMS vem tentando encontrar uma forma de abordar as consequências das doenças; em 1980 foi elaborada uma classificação denominada International Classification of Impairments, Disabilities and Handicaps (ICIDH) para ser utilizada e testada em pesquisas; depois adotada por serviços relacionados à reabilitação; passou por revisão; até que, depois de ter sido testada em mais de 50 países, envolvendo um número superior a 1.800 profissionais de saúde, em 2001, foi publicada a Classificação Internacional de Funcionalidade, Incapacidade e Saúde (CIF). ${ }^{473}$

Segundo Buchalla, essa classificação abre novos horizontes para a área da saúde; leva em consideração novos desafios que se apresentam, considerando o envelhecimento da população. Relata essa autora que os indicadores utilizados para planejamento de ações de saúde empregavam dados relativos à mortalidade, morbidade e nutrição, em geral; no entanto, com o envelhecimento, há um certo grau de limitação, que deve ser mensurada.

Nesse contexto, a CIF constitui um instrumento mais abrangente; ensina Cassia Buchalla que a classificação, na primeira parte, é relacionada à funcionalidade e à incapacidade; subdivide-se em dois componentes: funções do corpo e estrutura do corpo, e atividades e participação; a segunda parte, dos fatores contextuais, corresponde aos fatores ambientais, que incluem bens de consumo e tecnologia, suporte e serviços, atitudes e políticas; sua inclusão deu-se como resultado da participação de grupo de pessoas com necessidades especiais na elaboração da classificação. ${ }^{474}$

Admite tal autora, em publicação de 2003, que a CIF é um produto em desenvolvimento, que deverá ser aprimorado; permite a mensuração de vários aspectos relacionados à saúde e às condições de vida, o que torna complexa sua utilização. Destaca, no entanto, que vários países da Europa e da América do Norte têm trabalhado com essa classificação em medicina de reabilitação.

\footnotetext{
${ }^{473}$ BUCHALLA, Cassia Maria. A classificação internacional de funcionalidade, incapacidade e saúde. Acta Fisiátrica, São Paulo, 10(1): 29-31, 2003.

${ }^{474}$ Idem, ibidem.
} 
No entanto, no Brasil até o momento não se adota a CIF, e, pior que isto, não se pode dizer que efetivamente a Previdência Social esteja de fato efetuando a reabilitação profissional, pois o que se constata é a prática sem qualquer análise sobre a compatibilidade do estado de saúde e a funcionalidade do reabilitando com as atividades laborais propostas.

Expostas tais críticas, convém tecer rápida exposição cronológica da legislação previdenciária e a respectiva concepção dos diplomas legais, que afetam diretamente a realidade dos trabalhadores, em particular aos submetidos a condições laborais adversas, que culminam com o acometimento de doenças e ocorrência de acidentes do trabalho.

A primeira lei sobre seguridade no Brasil surge após a greve de 1917, quando houve paralisação de cerca de 45.000 operários de diferentes categorias em São Paulo. ${ }^{475}$

O Decreto Legislativo 3.724, de 15.01.1919, considerada a primeira norma a regular o pagamento de indenizações às vítimas de acidentes, beneficiava o trabalhador, responsabilizando o empregador pelo pagamento de indenização, de acordo com a sua gravidade. Em caso de incapacidade total e permanente ou morte, a indenização correspondia a três anos de salário da vítima; as despesas médicas e hospitalares também deviam ser ressarcidas. Havia previsão de que a vítima, seus familiares ou o patrão deveria comunicar a autoridade policial. ${ }^{476}$

Depois veio o Decreto 24.637, de 10.07.1934, contemporâneo à aceleração da industrialização e crescimento dos centros urbanos. Tal norma passou a abranger as doenças profissionais para fins de reparação e criou o seguro para garantia do pagamento das indenizações às vítimas. ${ }^{477} \mathrm{~A}$ participação crescente das categorias de trabalhadores urbanos propiciou a ampliação dos beneficiados, com a inclusão das domésticas, aprendizes e os empregados em empresas concessionárias de serviços públicos.

\footnotetext{
${ }^{475}$ RIBEIRO, Herval Pina; LACAZ, Francisco A. de Castro. Poeiras e doenças pulmonares. São Paulo: DIESAT, 1984. p. 25.

476 Idem, ibidem.

${ }^{477}$ LACERDA, Nadia Demoliner. Segurança e saúde do trabalhador: para onde vamos? O debate nacional sobre a concepção preventiva do novo seguro de acidente. São Paulo: LTr, 2011. p. 56.
} 
No final da Segunda Guerra Mundial entra em vigor o Decreto-lei 7.036, de 10.11.1944, em um momento de efervescente movimento político contra a ditadura de Vargas e pelas liberdades democráticas. Representa enorme avanço, define como acidente não somente os típicos e as doenças profissionais, como também todo evento que tenha relação de causa e efeito, ainda que não responsável único; pela primeira vez, a concausa fica caracterizada como acidente do trabalho. ${ }^{478}$ É também o primeiro diploma legal que cuida, ainda que de forma tímida, da prevenção dos sinistros, pois prevê como obrigação do empregador proporcionar segurança e higiene no trabalho, devendo os empregados observar o cumprimento dessas normas, expedidas pelo empregador.

O Decreto-lei 293, de 28.02.1967, entra em vigor ao final do mandato do primeiro Presidente, depois do golpe militar de 1964. Há retrocesso, com a eliminação do monopólio estatal, atribuindo caráter privado ao seguro de acidentes do trabalho; o órgão previdenciário operava em concorrência com as sociedades seguradoras. Esse diploma também eliminou o conceito de concausa, o nexo causal somente podia ser estabelecido de forma direta. ${ }^{479} \mathrm{O}$ decreto estabelece uma pensão mensal complementar à aposentadoria, em caso de incapacidade permanente ou morte, e uma indenização única quando a incapacidade parcial ou permanente for inferior a $25 \%$. No entanto, há aspecto positivo, pois o decreto admitiu os acidentes in itinere como acidentes do trabalho.

O monopólio estatal do seguro de acidentes é restabelecido pela Lei 5.316, de 14.09.1967, que traz vantagens: cria o pecúlio-acidente, substituindo a indenização fixa; que é incorporado ao salário, quando o acidente acarretar perda inferior a 25\%; cria o auxílio acidente, incorporável aos novos salários e à futura aposentadoria ou à pensão dos dependentes, quando a incapacidade parcial e permanente for superior a $25 \%$. Esta Lei estabelece a taxação individual por empresa, variável segundo o número de acidentes ocorridos. Prevê a concessão dos benefícios aos trabalhadores avulsos e aos presidiários,

\footnotetext{
${ }^{478}$ RIBEIRO, Herval Pina; LACAZ, Francisco A. de Castro. Poeiras e doenças pulmonares. São Paulo: DIESAT, 1984. p. 26.

${ }^{479}$ LACERDA, Nadia Demoliner. Segurança e saúde do trabalhador: para onde vamos? O debate nacional sobre a concepção preventiva do novo seguro de acidente. São Paulo: LTr, 2011. p. 56.
} 
trabalhem ou não; estabelece que $0,5 \%$ da arrecadação do seguro social será destinado à Fundacentro. ${ }^{480}$

A Lei 6.367, de 19.10.1976, configura retrocesso; a doença profissional ficou restrita à relação oficial de doenças organizada pelo Ministério da Previdência Social; a norma desprezou a análise das condições de trabalho como causas ou agravantes do acidente. $^{481}$ Para a percepção do auxílio suplementar, benefício devido quando há incapacidade, é possível o exercício da função desempenhada antes do acidente, embora com esforço permanente o Regulamento cria uma série de exigências, deixando inúmeras lesões sem qualquer proteção. Para as doenças, a concessão do auxílio suplementar revela situações absurdas, como é o caso dos portadores de silicose e asbestose, pois são considerados aptos a continuarem exercendo a mesma função agressiva. $\mathrm{O}$ auxílio-acidente é reduzido para 40\% (a Lei 5.316/1967 estabelecia percentuais de 30 a 60\%, conforme a possibilidade de o trabalhador exercer a mesma profissão, ou outra de nível igual ou inferior).

De acordo com essa norma, a percepção de auxílio-acidente ficou vinculada à abertura de CAT pela empresa. Portanto, aos segurados vítimas de acidentes do trabalho, e principalmente de doenças ocupacionais não comunicados à Previdência, outra alternativa não restava senão o ajuizamento de ações acidentárias em face do INSS, perante a Justiça Comum, em determinadas Comarcas perante as Varas Especializadas de Acidentes do Trabalho, como forma de obtenção do benefício. Registre-se aqui que à época sequer vigorava a proteção estabilitária em caso de acidente do trabalho, por 12 meses após a alta; assim, com a cessação do benefício o trabalhador acidentado retornava ao trabalho e era despedido.

A Constituição Federal é promulgada em 1988; a seguridade social passa a ser definida na forma do artigo 194, conforme mencionado, e três anos depois entra em vigor a Lei 8.213/1991, que dispõe sobre o Plano de Benefícios da Previdência Social; tal diploma legal já sofreu diversas alterações, como trataremos a seguir.

${ }^{480}$ RIBEIRO, Herval Pina; LACAZ, Francisco A. de Castro. Poeiras e doenças pulmonares. São Paulo: DIESAT, 1984. p. 27.

${ }^{481}$ LACERDA, Nadia Demoliner. Segurança e saúde do trabalhador: para onde vamos? O debate nacional sobre a concepção preventiva do novo seguro de acidente. São Paulo: LTr, 2011. 


\subsubsection{Aposentadoria especial}

A menção ao adicional de penosidade surgiu pela primeira vez na Lei Orgânica da Previdência Social, a Lei 3.807 de 1960, ao prever a concessão de aposentadoria especial para os trabalhos penosos. Na ocasião, foram consideradas penosas as atividades dos professores, motoristas e cobradores de ônibus, motoristas de caminhão e trabalhadores de subsolo, como galerias, poços e depósitos. Essa norma foi revogada e o adicional voltou a ser previsto no inciso XXIII do artigo 7. ${ }^{\circ}$ da Constituição Federal.

Assim, na origem da aposentadoria especial encontra-se o caráter compensatório ao trabalhador executante de atividade ou ocupação profissional reconhecida tecnicamente ou pelo senso comum, como nociva à saúde, pelo exercício em condições de insalubridade, periculosidade ou penosidade. Constitui-se, portanto, um benefício como forma de compensação para aqueles que se dispuseram ou não tiveram outra alternativa ocupacional, a não ser realizar atividades que expunham sua saúde ou integridade física aos riscos oriundos do trabalho.

A aposentadoria especial é um benefício previsto no artigo 57 da Lei 8.213/1991, com a redação dada pela Lei 9.032/1995, e "será devida [...] ao segurado que tiver trabalhado sujeito a condições especiais que prejudiquem a saúde ou a integridade física, durante 15 (quinze), 20 (vinte) ou 25 (vinte e cinco) anos, conforme dispuser a lei”.

Da consulta ao sítio do Ministério da Previdência Social verifica-se que a Aposentadoria Especial é:

Benefício concedido ao segurado que tenha trabalhado em condições prejudiciais à saúde ou à integridade física. Para ter direito à aposentadoria especial, o trabalhador deverá comprovar, além do tempo de trabalho, efetiva exposição aos agentes nocivos químicos, físicos, biológicos ou associação de agentes prejudiciais pelo período exigido para a concessão do benefício (15, 20 ou 25 anos). [...]

Além disso, a exposição aos agentes nocivos deverá ter ocorrido de modo habitual e permanente, não ocasional nem intermitente. $[. . .]^{482}$ (grifos nossos).

${ }^{482}$ Disponível em: http://www.previdencia.gov.br/conteudoDinamico.php?id=14. Acesso em: 5 dez. 2012. 
Tal orientação é extraída da previsão legal, do contido na Lei 8.213, de 24 de julho de 1991; na Lei 10.666, de 8 de maio de 2003; no Decreto 3.048, de 6 de maio de 1999, e alterações posteriores; bem como na Instrução Normativa INSS/PRES 45, de 6 de agosto de 2010.

Pode-se afirmar que a aposentadoria especial é, na medida em que reduz o tempo de exposição aos ambientes de trabalho com potencial de causar danos, um fator de prevenção e precaução. Esse é o pensamento de Cristiane Queiroz Barbeiro Lima, tecnologista do Serviço de Ergonomia da Fundacentro, que afirma que a premissa a ser adotada para a abordagem da aposentadoria especial é a de que a saúde é um direito que se concretiza por meio de ações de prevenção de acidentes e doenças relacionadas ao trabalho, considerando os conceitos de promoção da saúde e do bem-estar social e entendendo que a aposentadoria especial é apenas parte de um conjunto de ações em favor da segurança e saúde do trabalhador. ${ }^{483}$

Ocorre que tais ações vêm sofrendo modificações, e invariavelmente o foco está no custeio dos benefícios, e não na saúde do trabalhador.

Exemplo claro de alteração em prejuízo do trabalhador é o desaparecimento do conceito de penosidade na legislação previdenciária.

Importa dizer que os fundamentos que lastreavam a concessão da aposentadoria especial, até meados dos anos 1990, envolviam a insalubridade, a periculosidade e a penosidade. Com as alterações ocorridas com a Lei 9.032/1995, na gestão Fernando Henrique Cardoso, o conceito de penosidade foi desprezado, bem como o de periculosidade, passando a prevalecer somente o conceito de insalubridade, como definido na CLT, que leva em consideração somente os limites de tolerância relacionados aos agentes químicos, físicos e biológicos.

\footnotetext{
${ }^{483}$ FUNDACENTRO. Aposentadoria especial como instrumento de proteção à segurança e saúde dos trabalhadores. I Seminário sobre Aposentadoria Especial como um instrumento de proteção à segurança e saúde do trabalhador. Coordenação técnica de Cristiane Queiroz Barbeiro Lima. São Paulo: Fundacentro, 2010. p. 15.
} 
Nessa linha, a aposentadoria especial deixa de ser concedida por categoria; com a adoção do conceito da insalubridade e seus limites de tolerância, estabeleceu-se uma linha divisória entre a saúde e a doença, com visão monocausal acerca do surgimento da doença.

Nesse aspecto, Cristiane Barbeiro Lima aponta incoerências nas regras estabelecidas para a concessão do benefício, por exemplo, de acordo com o Anexo IV do Decreto 3.048/1999, a concessão é devida quando em caso de exposição do trabalhador a: a) agentes químicos, quando no ambiente de trabalho e no processo produtivo o nível de concentração for superior aos limites de tolerância previstos. Ocorre que são aproximadamente oitenta substâncias contempladas e não existe limite de tolerância legalmente estabelecido; b) para agentes físicos, a concessão é devida à exposição acima dos limites de tolerância especificados para ruído e temperatura anormais (somente o calor); para os agentes vibrações, radiações ionizantes e pressão atmosférica anormal, o texto diz simplesmente que deve haver concessão "às atividades descritas"; e c) para os agentes biológicos a concessão é devida unicamente por força da exposição às atividades relacionadas com micro-organismos e parasitas infectocontagiosos vivos e suas toxinas. No entanto, as atividades relacionadas desaparecem do texto da Instrução Normativa 29 INSS/PRES de $2008 .^{484}$

Destaca ainda Cristiane Queiroz Barbeiro Lima que o Decreto 4.882, de 18 de novembro de 2003, que alterou o Decreto 3.048, de 6 de maio de 1999, mudou o conceito de exposição a múltiplos agentes ou de fatores de risco à saúde, levando a considerar os agentes isoladamente, impondo limites de tolerância e descaracterizando a análise por atividade, definitivamente. Dessa forma, tais alterações, no que tange à relação adoecimento-exposição ocupacional e método de prevenção, configuraram limitações importantes, a saber:

a) definição de "Condições especiais" passa a considerar somente $o$ conceito de insalubridade baseado nos limites de tolerância;

b) visão unicausal em detrimento dos múltiplos fatores de risco presentes nas atividades de trabalho;

${ }^{484}$ FUNDACENTRO. Aposentadoria especial como instrumento de proteção à segurança e saúde dos trabalhadores. I Seminário sobre Aposentadoria Especial como um instrumento de proteção à segurança e saúde do trabalhador. Coordenação técnica de Cristiane Queiroz Barbeiro Lima. São Paulo: Fundacentro, 2010. p. 16. 
c) individualização do potencial de risco, levando em consideração somente um agente e uma exposição por trabalhador;

d) laudos com apenas informações sobre existência de tecnologia de proteção coletiva ou individual que diminua a intensidade do agente agressivo aos limites de tolerância e que deveriam recomendar a adoção pelo estabelecimento respectivo do Equipamento de Proteção Individual (EPI), considerando-se, ainda, que o EPI não elimina a presença do agente no ambiente de trabalho;

e) autodeclaração do empregador, que veio com a Lei n. 9.732/1998, a qual [...] ressalta no seu art. 19, inciso II, que é contravenção penal, punível com multa, deixar a empresa de cumprir as normas de segurança e higiene do trabalho. Ora, estar com exposição ocupacional acima dos limites de tolerância que caracterizariam a aposentadoria especial não seria, na maioria das situações encontradas, estar em desacordo com as normas de segurança e higiene do trabalho? [...]. ${ }^{485}$

Essa autora aponta ainda dificuldades técnicas na aplicação das regras de concessão da aposentadoria especial: a) os limites de tolerância são os estabelecidos na Norma Regulamentadora 15 - NR 15 da Portaria 3.214/1978, que se encontra desatualizada, principalmente no estabelecimento dos limites de tolerância para substâncias químicas, adotados em 1978; b) dificuldades na comprovação da eficácia dos equipamentos de proteção individual (EPIs); c) informações limitadas sobre as demonstrações ambientais e os vários entendimentos sobre o tempo de trabalho permanente; d) preenchimento do Perfil Profissiográfico Previdenciário (PPP), documento solicitado pela Previdência Social para comprovação de demonstrações ambientais: constata-se muitas vezes que tais informações são reduzidas ou induzidas acerca das situações de trabalho encontradas. ${ }^{486}$

Aliás, a esse respeito Cristiane Barbeiro Lima sugere, para que se possa utilizar o PPP como um instrumento de proteção à segurança e saúde do trabalhador, seja adotada a premissa do risco presumido (previsto e provável), com a aplicação do conceito da precaução (da cautela antecipada) e a valorização do trabalhador que necessita utilizar o EPI; salienta que devem ser avaliadas as situações que, mesmo em condições razoáveis de

${ }^{485}$ FUNDACENTRO. Aposentadoria especial como instrumento de proteção à segurança e saúde dos trabalhadores. I Seminário sobre Aposentadoria Especial como um instrumento de proteção à segurança e saúde do trabalhador. Coordenação técnica de Cristiane Queiroz Barbeiro Lima. São Paulo: Fundacentro, 2010. p. 17.

${ }^{486}$ Idem, ibidem, p. 17-18. 
controle atualmente preconizadas e admitidas, ainda ofereçam riscos à saúde ou à integridade física do trabalhador.

Antonio José de Arruda Rebouças alerta que a aposentadoria especial vem sendo desfigurada ao longo dos anos e coloca tal questão no bojo da verdadeira desconstrução de direitos sociais que vem sendo empreendida no sentido de distorcer ou mesmo de esvaziar a proteção social alcançada pela Constituição Federal de 1988. Destaca esse advogado e especialista em Previdência Social que o movimento sindical e os setores comprometidos com a sociedade buscaram consolidar os avanços constitucionais, concretizando-os por meio da legislação infraconstitucional. Cita como exemplo a Lei 8.213/1991, cuja redação original baseou-se no texto que as representações sindicais e seus técnicos apresentaram ao Congresso Nacional e no âmbito da Seguridade Social, a Lei Orgânica da Saúde, Lei 8.080/1990 e a Lei Orgânica da Assistência Social (LOAS), Lei 8.742/1993. ${ }^{487}$

Essa desconstrução dos direitos sociais opera-se de várias formas, esclarece Rebouças. Uma delas é a desfiguração da aposentadoria especial, que vem sendo empreendida ao longo dos anos. O artigo 201, § 1., da Constituição Federal dispunha originariamente que era vedada a adoção de critérios diferenciados para a concessão de aposentadoria, "ressalvados os casos de atividades exercidas sob condições especiais que prejudiquem a saúde ou a integridade física, definidos em lei complementar". E o Congresso Nacional, em vez de definir em lei complementar as condições especiais prejudiciais à saúde ou à integridade física, como dispunha originariamente o tal dispositivo, preferiram "constitucionalizar" a Lei 8.213/1991, por meio da Emenda Constitucional 20, de 16 de dezembro de 1998, publicada mais de dez anos depois da vigência da Carta, como prevê o seu artigo $15 .^{488}$

Antes, porém, da vigência da EC 20/1998, medidas provisórias foram convertidas em leis - Lei 9.032/1995; Lei 9.528/19 e Lei 9.732/1998 - que prepararam o terreno para a

\footnotetext{
${ }^{487}$ REBOUÇAS, Antonio José de Arruda. A aposentadoria especial e a desconstrução de direitos sociais, no regime geral da previdência social. I Seminário sobre aposentadoria especial como um instrumento de proteção à segurança e saúde do trabalhador. Coordenação técnica Cristiane Queiroz Barbeiro Lima. São Paulo, Brasil, 25 setembro 2008; São Paulo: Fundacentro, 2010. p. 19.

488 "Até que a lei complementar a que se refere o art. 201, § 1. ${ }^{\circ}$, da Constituição Federal, seja publicada, permanece em vigor o disposto nos arts. 57 e 58 da Lei n. 8.213, de 24 de julho de 1991, na redação vigente à data de publicação desta Emenda."
} 
Emenda Constitucional 20, pois eliminaram o direito à obtenção à aposentadoria especial pelo critério da atividade profissional, não mais importando a natureza da atividade, mas sim unicamente a exposição a agentes físicos, químicos e biológicos. Além disso, foi eliminado o direito ao benefício da aposentação especial nos casos de trabalhos penosos ou perigosos.

E, dentre outras mudanças, ressalte-se que, em vez de o Congresso Nacional ou a União legislar no sentido da proteção da saúde e da integridade física dos trabalhadores, passou a exigir do segurado a comprovação, perante o INSS, do exercício de trabalho habitual e permanente, não ocasional nem intermitente, sob condições especiais nocivas à saúde ou à integridade física.

E, ainda, a Lei 8.213/1991, que dispunha inicialmente que a relação de atividades profissionais nocivas ou à saúde ou à integridade física deveria ser objeto de lei específica, aprovada pelo Congresso Nacional, com a entrada em vigor da Lei 9.528/1997, retirou essa prerrogativa do Legislativo, para determinar que tal listagem passasse à esfera de competência do Poder Executivo, inviabilizando tal discussão com a sociedade.

A crítica às alterações legislativas também é feita por Sergio Pardal Freudenthal, que insiste na denominação técnica das condições laborais que devem definir o direito à aposentadoria especial como insalubres, periculosas e penosas; declarando que a definição da Carta de 1988 - "condições especiais, que prejudiquem a saúde ou a integridade física" - foi superficial e causou bastante confusão, agravada nas seguidas alterações legislativas, a partir da Lei 9.032 , de 28 de abril de $1995 .^{489}$

Sustenta Freudenthal, diferentemente do que muitos defendem, que

[...] as alterações dos artigos 57 e 58, da Lei n. 8.213/91, não atingiram o conceito do benefício Aposentadoria Especial. Aumentaram as exigências para comprovação de condições especiais de trabalho, alegando que se busca sanar supostos exageros na concessão do benefício, e nada mais.

A retirada do termo "atividade profissional" da lei, de forma alguma reduziria a noção de agentes agressivos ou de condições especiais apenas

${ }^{489}$ Disponível em: <http://www.pardaladvocacia.com.br/site/html/content/artigos/Detalhe.aspx?id=25\& pag=1>. Acesso em: 9 dez. 2012. 
para as insalubres, descaracterizando as periculosas e as penosas, como tenta defender o INSS.

Em síntese: aposentadoria especial é uma espécie de aposentadoria por tempo de serviço (atualmente denominada por tempo de contribuição), com a redução do período de labor em razão das condições insalubres, periculosas ou penosas, e com normas específicas sobre a comprovação de tais situações e exigências na concessão do benefício. Relaciona-se diretamente com as condições de trabalho, e isto suscitou a defesa de boa parte das alterações a partir de 1995, algumas das quais mereceram muitas críticas ${ }^{490}$ (grifos nossos).

Muitos são os críticos da aposentadoria especial. Entre eles encontra-se Celso Barroso Leite que diz que "parece fora de dúvida que não há lugar para a aposentadoria especial numa previdência social atualizada e racional"; acrescenta esse autor que os "advogados da aposentadoria especial parecem esquecer que ela tem no fundo a mesma natureza da aposentadoria por invalidez". ${ }^{491}$

Ousamos divergir desse especialista na matéria, pois uma Previdência Social atualizada e racional não deve primar exclusivamente pela ótica atuarial, de custeio, e sim deve empregar todos os seus esforços no cumprimento da missão consignada no artigo 194 da Constituição Federal, de forma a assegurar os direitos relativos à saúde, à previdência e à assistência social.

Nesse sentido, Maria Inês Miya Abe propõe uma Seguridade Social voltada aos direitos humanos e tece críticas à ideologia atual que propugna um determinismo econômico sem qualquer ressalva ou crítica, impondo perversamente como critério de implantação de políticas públicas o critério econômico sobre o social. ${ }^{492}$

Nesse sentido, uma Previdência Social atualizada e racional não deveria conceder bonificações sobre as contribuições sem a mínima fiscalização, como se verá.

\footnotetext{
${ }^{490}$ Disponível em: $\quad<$ http://www.pardaladvocacia.com.br/site/html/content/artigos/Detalhe.aspx?id=25\& pag=1>. Acesso em: 9 dez. 2012.

${ }^{491}$ LEITE, Celso Barroso. Considerações sobre Previdência Social. In: FREUDENTHAL, Sergio Pardal (Coord.). A Previdência Social hoje: homenagem a Anníbal Fernandes. São Paulo: LTr, 2004. p. 19-20.

${ }^{492}$ ABE, Maria Inês Miya. A seguridade social em função dos direitos humanos. 2007. Faculdade de Direito, Universidade de São Paulo, São Paulo.
} 
E, além disso, ao contrário do que sustenta o autor, a aposentadoria especial não tem a mesma natureza da aposentadoria por invalidez. Como o próprio termo evidencia, esta implica incapacidade e a aposentadoria especial é uma espécie de aposentadoria por tempo de serviço (atualmente denominada por tempo de contribuição), como afirma Sergio Pardal Freudenthal.

Como dissemos, a aposentadoria especial permite que o trabalhador seja retirado mais cedo do trabalho; nesse passo, trata-se de medida que possibilita ao trabalhador que labore menos tempo naquelas determinadas condições adversas, em especial as condições penosas, exatamente para evitar a invalidez.

Trata-se de medida de prevenção e aproxima-se da redução da jornada - esta retira o trabalhador mais cedo no dia e a aposentadoria especial o retira antecipadamente do trabalho depois de anos; configura ainda uma forma de compensação para aqueles obreiros que não tiveram outra opção laboral, não se confundindo com a monetização do risco.

Por fim, registre-se que, de acordo com o disposto no $\S 3 .^{\circ}$ do artigo 22 da Lei 8.212/1991, o Ministério da Previdência Social poderá alterar, com base nas estatísticas de acidentes do trabalho, apuradas em inspeção, o enquadramento de empresas para efeito da contribuição, a fim de estimular investimentos em prevenção de acidentes, mediante alíquota de contribuição progressiva para fins de benefício de aposentadoria especial aos trabalhadores cooperados de cooperativas de trabalho ou de produção.

\subsubsection{Grau de Incidência de Incapacidade Laborativa - Riscos Ambientais do Trabalho - GIIL RAT}

O caráter contributivo da Previdência Social está inserto na Constituição Federal, que adotou o sistema de financiamento direto, também chamado de alemão ou continental, visando proteger o valor do trabalho, da remuneração real ou presumida do segurado. Além do princípio da contrapartida, previsto no artigo 195, inciso III, do Diploma Maior, em decorrência de outro princípio, o protetor, previsto no artigo $33, \S 5 .^{\circ}$, da Lei 8.212/1991 - organização da Seguridade Social e Plano de Custeio -, presumem-se recolhidas as contribuições feitas pelo segurado empregado, ainda que seu empregador não 
as tenha recolhido, de acordo com a prevalência da solidariedade social sobre o seguro social. $^{493}$

Em grande parte, as contribuições sociais recolhidas à Previdência Social são suportadas pelos empregadores; basicamente, a contribuição patronal é de $20 \%$ sobre o total das remunerações pagas mensalmente aos empregados, avulsos e contribuintes individuais (os autônomos).

Além disso, os empregadores recolhiam o Seguro Acidentes do Trabalho (SAT), que após alterações legais passou a se denominar Grau de Incidência de Incapacidade Laborativa - Riscos Ambientais do Trabalho (GIIL RAT) -, percentual de contribuição para o financiamento previdenciário dos fundos destinados às aposentadorias especiais e aos benefícios concedidos aos empregados e trabalhadores avulsos em razão do grau de incidência de incapacidade decorrente de exposição a riscos ambientais do trabalho, nos termos do inciso II do artigo 22 da Lei 8.212/1991:

a) $1 \%$ (um por cento) para as empresas em cuja atividade preponderante o risco de acidentes do trabalho seja considerado leve;

b) $2 \%$ (dois por cento) para as empresas em cuja atividade preponderante esse risco seja considerado médio;

c) 3\% (três por cento) para as empresas em cuja atividade preponderante esse risco seja considerado grave. ${ }^{494}$

\subsubsection{Nexo Técnico Epidemiológico - NTEP}

Importante alteração legislativa foi aquela promovida pela Lei 11.430/2006, que acrescentou o artigo 21-A à Lei 8.213/1991, instituindo o chamado Nexo Técnico Epidemiológico (NTEP). ${ }^{495}$ Trata-se de uma verdadeira mudança de paradigma, pois o

${ }^{493}$ GUELLER, Marta Maria R. Penteado. A aposentadoria e as recentes alterações introduzidas na legislação previdenciária. In: FREUDENTHAL, Sergio Pardal (Coord.). A Previdência Social hoje: homenagem a Anníbal Fernandes. São Paulo: LTr, 2004. p. 181.

${ }^{494}$ LACERDA, Nadia Demoliner. Segurança e saúde do trabalhador: para onde vamos? O debate nacional sobre a concepção preventiva do novo seguro de acidente. São Paulo: LTr, 2011. p. 70.

495 “Art. 21-A. A perícia médica do INSS considerará caracterizada a natureza acidentária da incapacidade quando constatar ocorrência de nexo técnico epidemiológico entre o trabalho e o agravo, decorrente da relação entre a atividade da empresa e a entidade mórbida motivadora da incapacidade elencada na Classificação Internacional de Doenças - CID, em conformidade com o que dispuser o regulamento. 
nexo de causalidade entre doenças e acidentes do trabalho e as atividades laborais passa a se dar a partir da epidemiologia.

O NTEP tem o objetivo de estabelecer automaticamente o nexo entre o trabalho e o agravo, causa do afastamento, classificado conforme o Código Internacional de Doenças (CID), evidenciando as causas mais frequentes de afastamento em cada empresa, de acordo com o Código de Atividade Econômica (CNAE).

O Decreto 6.042, de 12.02.2007, deu nova redação ao artigo 337 do Decreto 3.048/1999 (o Regulamento da Previdência Social), prevendo que cabe à perícia médica do INSS caracterizar o acidente do trabalho mediante a identificação do nexo entre o trabalho e o agravo, considerados: o acidente e a lesão; a doença e o trabalho; e a causa mortis e o acidente.

Como destaca Raimundo Simão de Melo, essa alteração legal objetivou diminuir as dificuldades sofridas pelo trabalhador, que tinha de demonstrar o nexo causal para caracterização das doenças ocupacionais, e, diante da negativa das empresas em expedir a Comunicação de Acidente do Trabalho (CAT), era elevado o índice de subnotificações. ${ }^{496}$

Trata-se de importante e elogiável avanço, pois por força desse diploma legal passa a existir a presunção de que a moléstia foi adquirida em decorrência do exercício peculiar a determinada atividade ou pelas condições em que o trabalho é realizado e com ele se relaciona diretamente; assim, tem natureza ocupacional. Logo, deu-se a inversão do ônus da prova, passando a incumbir à empresa a demonstração de ausência de caráter ocupacional do agravo à saúde do trabalhador. ${ }^{497}$

$\S 1 .^{\circ}$ A perícia médica do INSS deixará de aplicar o disposto neste artigo quando demonstrada a inexistência do nexo de que trata o caput deste artigo.

$\S 2 .^{\circ}$ A empresa poderá requerer a não aplicação do nexo técnico epidemiológico, de cuja decisão caberá recurso com efeito suspensivo, da empresa ou do segurado, ao Conselho de Recursos da Previdência Social."

${ }^{496}$ MELO, Raimundo Simão de. Direito ambiental do trabalho e a saúde do trabalhador: responsabilidades legais, dano material, dano moral, dano estético, indenização pela perda de uma chance, prescrição. São Paulo: LTr, 2008. p. 145.

${ }^{497}$ Idem, ibidem, p. 146. 
Assim, reconhecida pela perícia médica do INSS a incapacidade para o trabalho, com o nexo causal estabelecido mediante o cruzamento de dados, o órgão previdenciário reconhece o direito às prestações previdenciárias acidentárias cabíveis, como auxíliodoença acidentário; auxílio-acidente; aposentadoria por invalidez acidentária; ou pensão por morte. E, a partir da concessão do auxílio-doença acidentário, há garantia de estabilidade no emprego pelo período de 12 meses após a alta médica, independentemente da percepção de auxílio-acidente, nos termos do artigo 118 da Lei 8.213/1991.

A instituição do NTEP, no entanto, não desobriga as empresas da emissão da CAT, conforme previsto nos arts. 19 a 23 da Lei 8.213/1991, e de acordo com o contido no artigo 9. ${ }^{\circ}$ na Instrução Normativa INSS/PRES 16, de 27.03.2007.

Cabe ressaltar que, assim que introduzida no ordenamento jurídico, a mencionada presunção legal do estabelecimento do nexo de causalidade teve sua constitucionalidade questionada perante o Supremo Tribunal Federal por meio da Ação Direta de Inconstitucionalidade (ADIn) 3.931, ajuizada pela Confederação Nacional da Indústria (CNI). A entidade patronal sustenta que o artigo 21-A da Lei 8.213/1991 e os $\S \S 3 .^{\circ}, 5^{\circ}{ }^{\circ}$ a 13 do referido artigo 337 do Decreto 3.048/1999 são inconstitucionais, por violarem o $\S 1$. $^{\circ}$ do artigo 201, o inciso XXVIII do artigo $7 .^{\circ}$ e o inciso XIII, artigo 5..$^{\circ}$, da Constituição Federal. Esta ação encontra-se atualmente conclusa à relatora, Ministra Carmem Lúcia, para apreciação do pedido de reconsideração do despacho que indeferiu o ingresso da Associação Nacional dos Magistrados da Justiça do Trabalho (Anamatra), na condição de amicus curiae, por ausência de pertinência temática, não tendo havido ainda pronunciamento acerca da constitucionalidade dos aludidos dispositivos. ${ }^{498}$

Outras críticas foram formuladas contra o NTEP, vindas especialmente da seara patronal, como a de que a adoção to NTEP poderia propiciar riscos de supernotificações de doenças ocupacionais inexistentes, além do desprezo de predisposições genéticas do trabalhador, bem como de que o aumento dos custos com prevenção levaria a substituição da mão de obra pela automação.

\footnotetext{
${ }^{498}$ Disponível em: <http://www.stf.jus.br>. Acesso em: 10 dez. 2012.
} 
Tais críticas não prosperam. Em primeiro lugar, no tocante à fundamentação contida na ADIn 3.931, não se configura a afronta ao artigo 201, § 1. ${ }^{\circ}$, da $\mathrm{CF}$, pois o reconhecimento do nexo técnico epidemiológico pelo INSS leva à caracterização da natureza acidentária da incapacidade, não podendo se inferir daí que por essa razão o trabalhador obterá a concessão da aposentadoria especial. Em segundo lugar, a adoção do NTEP não propicia riscos de notificações inexistentes de doenças ocupacionais, ou de desprezo às predisposições da vítima, na medida em que o médico perito pode deixar de aplicar o nexo técnico epidemiológico, quando dispuser de dados que descaracterizem o nexo causal; esses dados são passíveis de demonstração pelo empregador, e a este sempre são assegurados o contraditório e a ampla defesa.

Observe-se que o Ministério da Previdência Social constituiu, por meio da Portaria 128, de 16.04.2008,

Comissão Consultiva com a finalidade de acompanhar, avaliar e propor ajustes ao Fator Acidentário de Prevenção - FAP, e ao Nexo Técnico Epidemiológico Previdenciário - NTEP, de que tratam, respectivamente, os arts. 202-A e 337, do Decreto n. 3.048, de 6 de maio de $1999 .{ }^{499}$

Cabe a essa Comissão acolher, analisar e encaminhar propostas de solução das questões derivadas de críticas e sugestões apresentadas acerca do FAP e do NTEP, inclusive no caso de aprimoramento da metodologia de aferição do desempenho das empresas.

No entanto, essa Comissão de acompanhamento do NTEP não saiu do papel, da intenção registrada em portaria, pois não é acionada.

De todo modo, reitere-se que a introdução do Nexo Técnico Epidemiológico no ordenamento jurídico trouxe inúmeros benefícios ao empregado, com a redução da burocracia para a concessão de benefícios acidentários. Em face da presunção do nexo entre o CNAE e o CID, o trabalhador foi poupado da difícil tarefa de produzir provas diagnósticas. Ademais, o NTEP não afronta qualquer princípio constitucional, ao revés, dá

${ }^{499}$ Publicada no Diário Oficial da União em 17.04.2008, p. 21-22. 
relevância ao princípio da dignidade da pessoa humana, além de respeitar os princípios da ampla defesa e do contraditório.

E a inversão do ônus da prova está correta não somente por eximir o trabalhador, como também por ter o empregador maior facilidade de acesso à informação, já que se obriga a manter atualizada a documentação relativa às condições do meio ambiente de trabalho, referentes ao Perfil Profissiográfico Previdenciário (PPP), Programa de Controle Médico de Saúde Ocupacional (PCMSO), Programa de Prevenção de Riscos Ambientais (PPRA) e Atestado de Saúde Ocupacional (ASO).

E mais, a inversão do ônus da prova determinada pelo NTEP serve de motivação para as empresas serem mais cuidadosas com o meio ambiente de trabalho; o estabelecimento automático do nexo entre os afastamentos e a causa médica apontada pelo CID conforme o CNAE induz ao cumprimento das normas de segurança e medicina do trabalho, tendo como consequência a prevenção da ocorrência de acidentes.

Portanto, essa mudança de paradigma foi positiva no que tange à prevenção da saúde dos trabalhadores.

\subsubsection{Fator Acidentário de Prevenção - FAP}

A primeira pergunta que deve ser feita acerca do Fator Acidentário de Prevenção (FAPé: ele, efetivamente, resulta na prevenção de acidentes do trabalho?

Antes de respondermos, vejamos como foi instituído tal fator e como funciona o seu mecanismo de efetiva aplicação. A Previdência Social, a partir de 2004, inicia uma abordagem com foco diferente dos acidentes e doenças ocupacionais, partindo da epidemiologia, entendida como o estudo da população exposta a fatores de risco.

As alterações da legislação previdenciária prosseguiram com a edição do Decreto 6.042, de 12 de fevereiro de 2007, que acrescentou ao Decreto 3.048, de 6 de maio de 1999, o artigo 202-A, disciplinando a aplicação, acompanhamento e avaliação do Fator Acidentário de Prevenção (FAP), de que tratou a Lei 10.666, de 8 de maio de 2003. 
O FAP é um multiplicador variável das alíquotas do GIIL - RAT, que pode reduzir em até $50 \%$ ou aumentar em até $100 \%$, considerando o desempenho anual da empresa em relação às demais do mesmo segmento econômico e em relação ao seu próprio desempenho na prevenção de acidentes e doenças ocupacionais. Portanto, a partir de 2010, quando o FAP passou a produzir efeitos tributários, as contribuições obrigatórias dos empregadores para o financiamento da Seguridade Social consistem em contribuição fixa mensal de $20 \%$ sobre a folha de salários e contribuições variáveis, fixadas entre $1 \%$ a $3 \%$, conforme a majoração ou redução, de acordo com a aplicação do FAP.

Tal fator foi instituído pelo Ministério da Previdência Social (MPS) como "proteção para o trabalhador e sua família", como se vê no sítio do Ministério. Na página oficial, o FAP é um importante instrumento das políticas públicas relativas à saúde e segurança no trabalho e permite a flexibilização da tributação coletiva dos Riscos Ambientais do Trabalho (RAT), com redução ou majoração das alíquotas RAT de 1\%, 2\% e 3\%, segundo o desempenho de cada empresa no interior da respectiva Subclasse da CNAE.

Digamos que do ponto de vista conceitual o FAT é correto e sua aplicação reverteria na redução dos acidentes e doenças do trabalho, na medida em que a possibilidade da redução da alíquota em até $50 \%$ está diretamente vinculada à inexistência de óbitos de trabalhadores, de concessão de benefícios previdenciários por invalidez permanente e de baixa taxa de rotatividade de mão de obra.

Desse modo, a empresa que demonstra que adotou medidas voltadas à prevenção e diminuição de acidentes e moléstias ocupacionais e não registra nenhuma morte por acidente do trabalho é premiada, ao mesmo tempo em que a redução da alíquota em até $50 \%$ está vinculada à inexistência dos registros acima mencionados - é a chamada trava de mortalidade e invalidez e rotatividade de mão de obra. Registre-se que a Resolução MPS/CNPS 1.269/2006 estabeleceu a medotologia para a geração do FAP anual.

Ocorre que lamentavelmente em solo pátrio aquilo que é previsto conceitualmente, que do ponto de vista teórico pode ser elogiável e positivo, na prática, o que se constata muitas vezes é a situação oposta. 
De início, saliente-se que os indicadores nos quais se baseia a Previdência Social para calcular a bonificação são fornecidos unilateralmente pelas empresas, sem que haja qualquer verificação desses dados, por parte dos órgãos públicos. Além disso, tais informações, pode-se afirmar, são "secretas”, sigilosas.

O Ministério da Previdência Social não disponibiliza essas informações, por exemplo, sequer ao Ministério do Trabalho e Emprego, ou ao seu órgão responsável pela promoção da saúde e segurança dos trabalhadores, a Fundacentro. Nesse sentido, a Previdência não observa o princípio constitucional da publicidade, que norteia a administração pública, à luz do artigo 37 da Carta.

Aliás, a inconsistência na divulgação dos dados do FAP, mesmo sob a ótica empresarial, é objeto de críticas, como destaca Nadia Demoliner Lacerda, que chama a atenção para a fragilidade da reforma previdenciária neste tópico, pois,

[...] ao estabelecer metodologia comparativa entre os dados de todas as empresas de uma mesma subclasse de CNAE, o Conselho Nacional da Previdência Social pecou em não dar publicidade dos dados de todas as empresas para todas elas.

Ora, para que cada empresa individualmente considerada, possa conferir o seu desempenho anual na prevenção de riscos ocupacionais e aferir se estão corretas as informações que resultaram em aumento da sua alíquota, por exemplo, é essencial ter acesso a todos os dados que o governo utilizou para chegar à sua alíquota. Trata-se de um item elementar e essa falha nos parece extremamente perigosa para o futuro da reforma previdenciária. $[\ldots]^{500}$

Nesse passo, além da inobservância do princípio constitucional da publicidade, causa estranheza e merece severa crítica dar tratamento sigiloso ao que deve ser tornado público.

Some-se a essas inconsistências a fiscalização precária: estudo encomendado pelo Sindicato Nacional dos Auditores Fiscais do Trabalho (SINAIT) ao IPEA constatou que para a Auditoria Fiscal do Trabalho conseguir combater efetivamente os acidentes de trabalho que vêm acontecendo pelo País são necessários mais 5.700 Auditores Fiscais, que

${ }^{500}$ LACERDA, Nadia Demoliner. Segurança e saúde do trabalhador: para onde vamos? O debate nacional sobre a concepção preventiva do novo seguro de acidente. São Paulo: LTr, 2011. p. 75. 
somados aos 2.987 em atividade hoje formariam um contingente capaz de atender as 7 milhões de empresas e os 44 milhões de empregados no mercado formal de trabalho. Atualmente, a média é de um Auditor Fiscal para fiscalizar 3 mil empresas. ${ }^{501}$ Tais números evidenciam que a fiscalização do meio ambiente de trabalho nas empresas é praticamente inexistente, como já foi destacado em tópicos anteriores.

Acerca das bonificações recebidas pelas empresas com a aplicação do FAP, em 04.11.2009, o Diretor do Ministério da Previdência Social divulgava as seguintes estimativas, a partir de janeiro de 2010, quando a metodologia passaria a ser aplicada:

Pagarão sempre as empresas que tiverem média de acidentalidade superior ao do seu setor econômico por não terem investido em prevenção. Das 952.561 empresas que integram 1.301 subclasses ou atividades econômicas, $879.933(92,37 \%)$ serão bonificadas, e 72.628 (7,62\%) terão aumento do SAT. Portanto, mais de $90 \%$ de todos os setores econômicos serão bonificados. O importante é que as empresas com o acréscimo repensem melhor suas políticas de saúde e segurança para poder diminuir nos próximos anos os índices de acidentalidade. É bom destacar que, a partir de janeiro de 2010 - data em que a nova metodologia começará a ser aplicada -, 3,3 milhões de empresas do Simples Nacional ficarão isentas de qualquer contribuição ao seguro ${ }^{502}$ (grifo nosso).

O cotejo dos números acima com os dados constantes do quadro elaborado com base nas informações do próprio Ministério da Previdência (v. quadro do tópico 1.2.4 Custo social e custo previdenciário) nos leva a concluir que algo está errado, pois o número de acidentes com invalidez temporária, permanente e mesmo morte não aponta a redução constante dos índices do FAP.

Não obstante o apelo e o estímulo para que as empresas invistam em saúde e segurança no meio ambiente de trabalho, chama a atenção o percentual de bonificação concedido - mais de $90 \%$ de todos os setores econômicos.

\footnotetext{
${ }^{501}$ Conf. Sindicato Nacional dos Auditores Fiscais do Trabalho. 13 set.2012. Disponível em: $<$ http://www.sinait.org.br/noticias_ver.php?id=6162>. Acesso em: 5 dez. 2012.

502 Declarações de Remígio Todeschini, em 04.11.2009, às 15 horas. Disponível em: $<$ http://www.previdencia.gov.br/vejaNoticia.php?id=36106>. Acesso em: 5 dez. 2012.
} 
O Fator Acidentário de Prevenção 2012, com vigência em 2013, indica que um número maior de empresas será bonificado, como se constata no sítio do Ministério da Previdência Social:

"[...] foi calculado para 1.029.964 empresas - integrantes de 1.301 subclasses de atividades econômicas. O FAP foi atualizado com base no histórico de acidentalidade de 2010 e 2011 e altera as alíquotas da tarifação individual por empresa do Seguro-Acidente.

Do total das empresas, 939.867, ou 91,5\%, serão bonificadas na aplicação do FAP 2012. Dessas, 803.063 terão a maior bonificação possível $-0,5$ - e poderão ter o seu seguro acidente reduzido pela metade. Somente $8,48 \%$ das empresas terão aumento (malus) na alíquota de contribuição ao Seguro Acidente em 2013, pois apresentaram acidentalidade superior à média do seu setor econômico ${ }^{503}$ (grifo nosso).

Ora, da análise do número de acidentes e doenças do trabalho ocorridos e registrados sob a ótica do Nexo Técnico Epidemiológico (NTEP), como se pode verificar no gráfico a seguir, considerado o mesmo período, os resultados não apontam a redução que justifique tão elevado grau de bonificação concedido pelo FAP: ${ }^{504}$
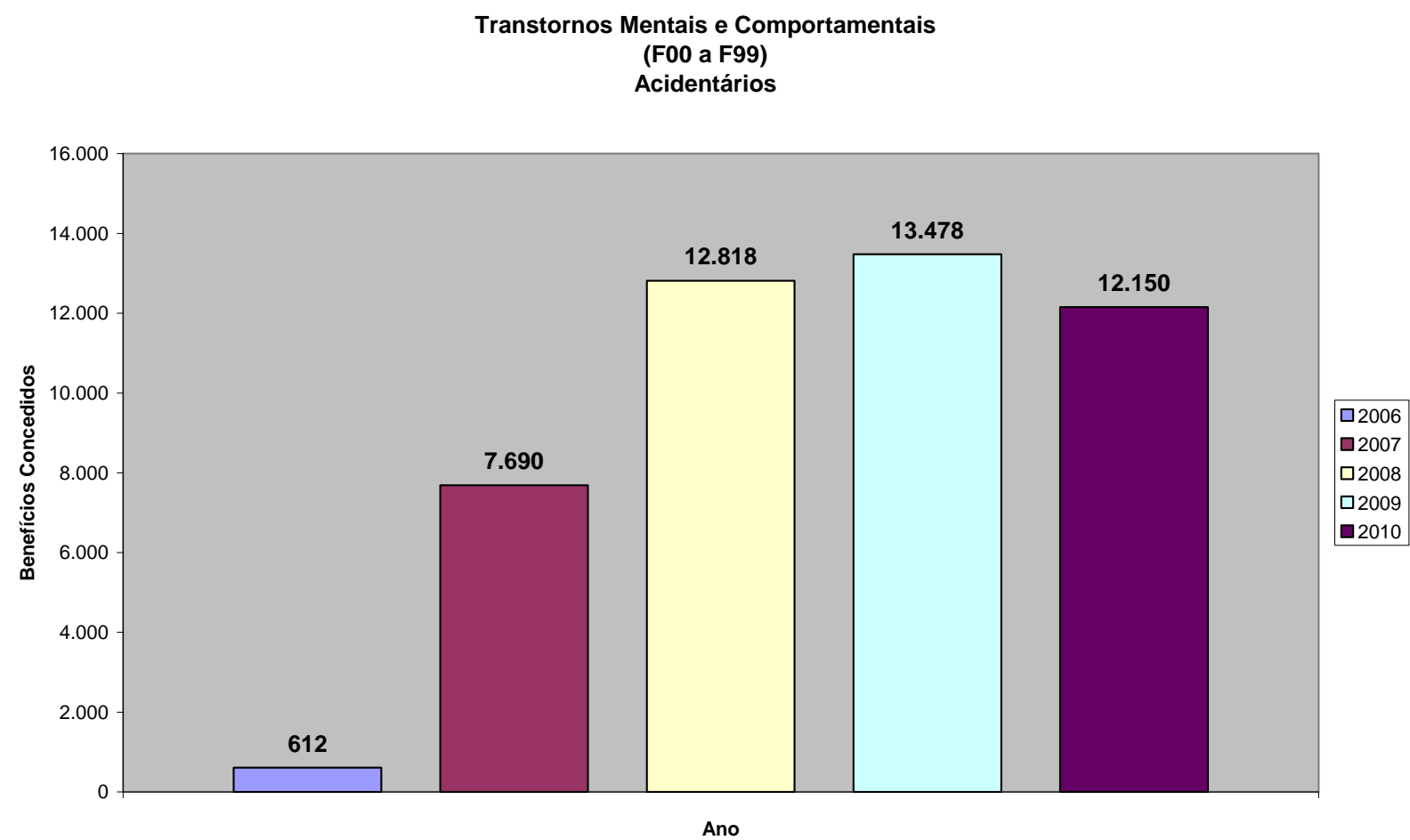

\footnotetext{
${ }^{503}$ Disponível em: <http://www.previdencia.gov.br/vejaNoticia.php?id=47776>. Acesso em: 1. ${ }^{\text {o }}$ out. 2012.

${ }^{504}$ Disponível em: <http://fundacentro.gov.br $>$ e $<$ http://www.mps.gov.br/conteudoDinamico.php?id=502>.
} 
Assim, no quadro acima constata-se, de acordo com informações do próprio Ministério da Previdência Social, que houve ligeira redução de ocorrências de transtornos mentais e comportamentais acidentários de 2009 para 2010.
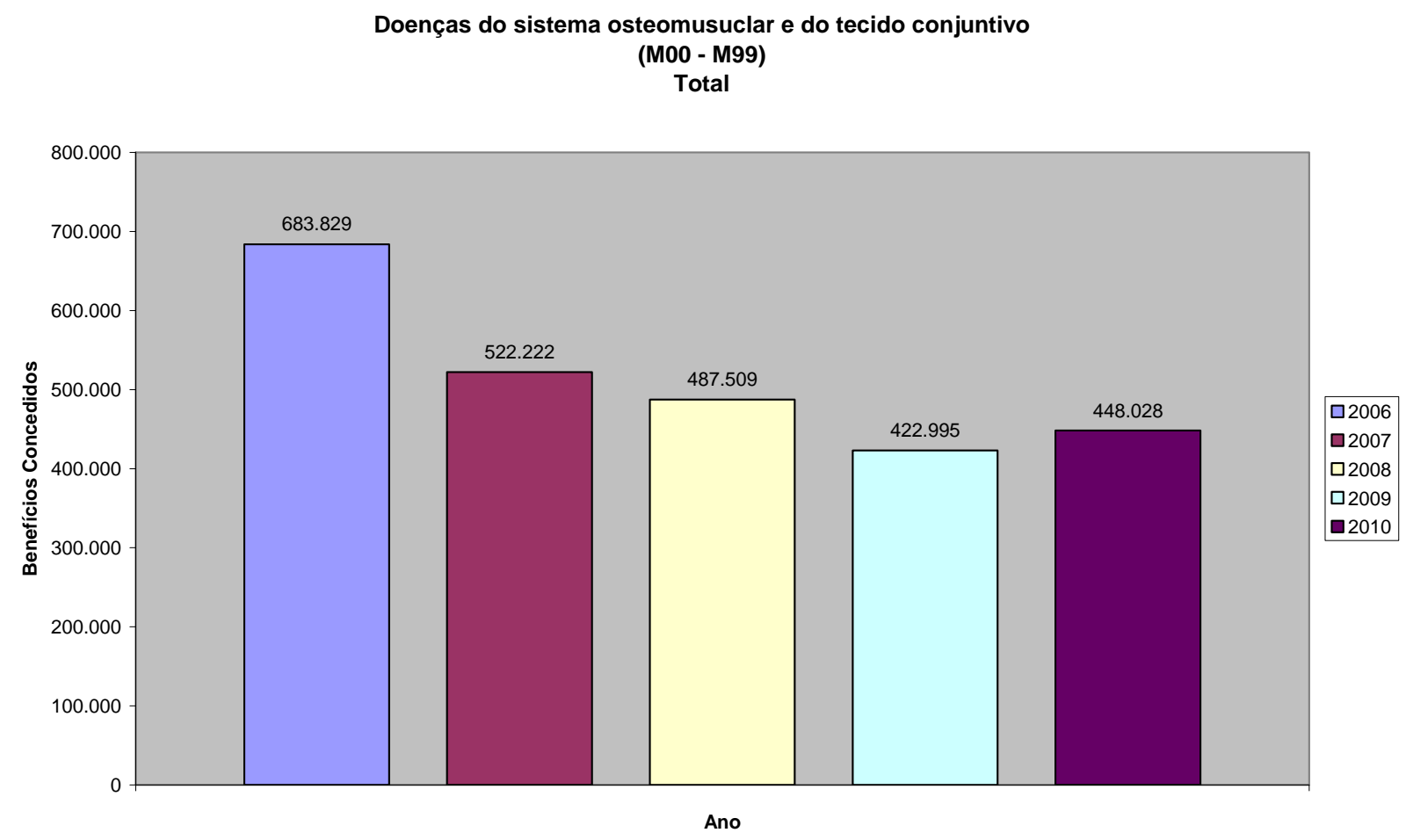

De acordo com os gráficos acima, que registram as doenças do sistema osteomuscular e do tecido conjuntivo, conforme o NTEP, houve elevação do número de registros, do ano de 2009 para 2010. Dessa forma, os dados colidem: como é possível que em 2010 mais de $90 \%$ de todos os setores econômicos tenham sido bonificados, pelo FAP, se em conformidade com o NTEP há elevação?

As bonificações continuarão em 2013, conforme notícia transmitida pela Rádio Previdência, de $02.10 .2012 .^{505}$ Ainda assim, o setor empresarial também tem dirigido

505 "Em 2013, quase um milhão de empresas de diversos segmentos terão a alíquota do SAT, o Seguro Acidente de Trabalho, reduzida em até 50\%. Isso se deve à aplicação do FAP, o Fator Acidentário de Prevenção. Criado em 2009, o FAP é um fator multiplicador que reduz a alíquota de empresas que não apresentaram acidentes ou doenças de trabalho." 
críticas ao FAT, seja por entender que se trata de contribuição nova, criada por decreto e, portanto, inconstitucional; por apresentar distorções quanto ao grau de risco, em face da aplicação de um único percentual para o CNPJ raiz (por exemplo, um único percentual para empresa petrolífera, tanto na plataforma em alto-mar quanto no escritório, em terra firme), bem como no que diz respeito à periodicidade com que as informações ambientais serão consideradas para o cálculo anual.

Na realidade, o FAP não representa outra fonte de custeio, trata-se de uma forma de flexibilização de tributo anteriormente criado. Registre-se que a inconstitucionalidade vem sendo reconhecida pelo Poder Judiciário, em decisões de primeira instância. No entanto, como observa Nadia Demoliner Lacerda, a variação das alíquotas pode constituir um problema jurídico para quem sofreu acréscimo de contribuição, mas, por outro lado, tal critério pode resultar em redução da alíquota. ${ }^{506}$

A nosso ver, no entanto, o maior problema é a falta de confiabilidade no próprio FAP, como já foi dito. Não é crível que esse Fator, efetivamente, esteja retratando uma realidade de redução de acidentes e doenças do trabalho, pois as informações são prestadas unilateralmente pelo empresariado, sem que haja qualquer fiscalização oficial. Ora, questiona-se: os empregadores, diante nesse contexto, iriam fornecer dados contrários aos seus próprios interesses, já que não serão verificados pelo governo? Por óbvio, as empresas não vão admitir as falhas; nesse sentido, apresentam PCMSO e PPRA “perfeitos”.

Prova disso são os números do NTEP, que demonstram o contrário do que revela o FAT.

Outro aspecto que deve ser destacado, e também é objeto de crítica, refere-se à atuação dos sindicatos das categorias profissionais; antes já foi mencionado que lamentavelmente os dirigentes sindicais brasileiros ainda não se conscientizaram da importância de um meio ambiente de trabalho seguro, como forma de preservação da saúde

Disponível em: <http://www.previdencia.gov.br/vejaNoticia.php?id=47797>. Notícia divulgada em: 2 out. 2012.

${ }^{506}$ LACERDA, Nadia Demoliner. Segurança e saúde do trabalhador: para onde vamos? O debate nacional sobre a concepção preventiva do novo seguro de acidente. São Paulo: LTr, 2011. p. 73. 
física e mental dos trabalhadores; dedicam-se com afinco muito maior às questões econômicas.

Como é sabido, a redução das alíquotas do GIIL-RAT em até $50 \%$ está vinculada à inexistência de óbitos de trabalhadores, de concessão de benefícios previdenciários por invalidez permanente e de baixa taxa de rotatividade de mão de obra - a chamada trava de mortalidade e invalidez e rotatividade de mão de obra. Ocorre que os sindicatos dos trabalhadores têm sido chamados pelas empresas para comprovar que tem havido melhora no meio ambiente de trabalho; as entidades sindicais têm muitas vezes atestado que a empresa demonstrou que adotou medidas voltadas à prevenção e diminuição de acidentes e moléstias ocupacionais; desse modo, a "comprovação sindical" serve para "destravar" para que a empresa possa receber a bonificação. Essa situação sugere cooptação dos sindicatos; não é esse o papel que se espera de entidade representativa de trabalhadores, tampouco é procedimento de uma empresa séria, que se preocupa efetivamente com a saúde e segurança de seus empregados.

Diante de todos os fatores elencados, impõe-se, assim, revogar a legislação que instituiu o Fator Acidentário de Prevenção (FAP) e propor outra norma, efetivamente voltada à prevenção e à proteção da saúde e da integridade física e mental dos trabalhadores; a que atualmente se encontra em vigor transformou-se em um instrumento de premiação do capital, sem qualquer compromisso com a melhoria das condições de trabalho.

\subsection{A reparação dos danos ao trabalhador e o ressarcimento do custo social}

Para que se possa atingir a efetiva reparação dos danos decorrentes de doenças e acidentes do trabalho, com ressarcimento social dos danos, e, mais que isso, a fim de que seja alcançada a tão almejada prevenção dos riscos no meio ambiente de trabalho, e para que os trabalhadores não sejam submetidos a condições laborais adversas, penosas, que culminam não raras vezes em óbito, é preciso, em primeiro lugar, revogar a legislação que instituiu o FAP. 
Por óbvio, a revogação não pode deixar um vazio, pois o que se pretende é buscar alternativas factíveis que concretamente resultem na preservação da saúde, da integridade física e mental do trabalhador.

Nesses termos, várias etapas devem ser cumpridas e determinadas ações devem ser concomitante e perenemente desenvolvidas para se atingir tal meta.

Em segundo lugar, é preciso terminar de vez com a multiplicidade de fontes e de dados, oriundos de vários órgãos públicos que colidem entre si, acerca dos registros das doenças e acidentes do trabalho, para que exista no Brasil informação pública e tecnicamente confiável; para tanto, mister se faz instituir um Cadastro Nacional Unificado das doenças e acidentes do trabalho. Pode-se inclusive discutir se a competência seria de um único Ministério; o ideal seria que houvesse uma integração de informações, com cruzamento de dados entre os Ministérios da Saúde, do Trabalho e Emprego e da Previdência Social. No entanto, como há uma enorme capilaridade na estrutura desses órgãos, com atuação nas esferas federal, estadual e municipal, o que importa aqui não é definir competências administrativas, que inclusive escapa do objeto de um trabalho acadêmico.

O que se pretende é propor a criação desse cadastro, instituído por lei, implantado por meio de um sistema disponibilizado a todos os que possam efetuar o registro de acidentes do trabalho, utilizando-se dos mais avançados recursos tecnológicos, que pudessem garantir a confiabilidade, segurança e atualização dos dados. As informações seriam inseridas com a identificação do segurado, a mais completa possível, e com as informações sobre o sinistro ou a doença do trabalho. Dessa forma, seria possível analisar, por meio do exame de dados confiáveis, se o número de doenças ocupacionais e de acidentes do trabalho no Brasil efetivamente vem caindo ou elevando-se; identificar os setores da economia e as empresas responsáveis pela eclosão de maior número de moléstias ocupacionais e de acidentes do trabalho.

Em terceiro lugar, esforços devem ser empreendidos, em especial pelos poderes públicos, para que a fiscalização do meio ambiente de trabalho no Brasil seja uma uma realidade; não é demais reiterar, ainda que tal questão já tenha sido apontada em tópicos anteriores, que os princípios ambientais da prevenção ou da atuação preventiva e da 
precaução devem fazer parte de políticas públicas, em todos os poderes públicos, de todas as unidades da Federação.

Nesse sentido, como forma de colocar em prática tais princípios, necessário se faz destinar maior aporte de recursos; realizar concursos públicos, em especial para os cargos com atribuições na fiscalização do meio ambiente de trabalho.

Em quarto lugar, a nova legislação que deverá revogar a atual deveria ser elaborada nos moldes da mencionada Portaria Interministerial 323/2012, com a participação de representante do Ministério da Previdência Social; Ministério do Trabalho e Emprego; Ministério da Saúde; Ministério do Planejamento, Orçamento e Gestão; Instituto Nacional do Seguro Social (INSS); Fundação Jorge Duprat Figueiredo de Segurança e Medicina do Trabalho (Fundacentro); Fundação Oswaldo Cruz (Fiocruz), bem como de representantes dos trabalhadores, indicados pelas Centrais Sindicais.

Nesse passo, o novo diploma legal até poderia prever redução de alíquota de contribuições, como forma de estimular o investimento em medidas de proteção à saúde dos trabalhadores, desde que os dados fornecidos pelas empresas fossem objeto de fiscalização, realizada pelo órgão competente, naquela determinada unidade da federação, que atestasse a efetiva redução de acidentes e doenças do trabalho e comprovasse a baixa rotatividade de mão de obra.

Essa nova legislação deveria prever que à fiscalização incumbiria a realização de perícia administrativa, por ramo de atividade econômica, que atestaria a existência, em determinadas atividades, de trabalho penoso.

E nas empresas em que se constatar o aumento do número de acidentes, ocorrência de acidente fatal, bem como de trabalho penoso, o que se propõe não é simplesmente deixar de haver a redução da alíquota GIIL-RAT, como ocorre hoje, e sim elevar a taxação, como forma indenização punitiva, revertida à Previdência Social.

Questionamentos poderiam surgir, inclusive de inconstitucionalidade, de bitributação, de bis in idem na cobrança. Não prospera. De início, ressalte-se a regularidade quanto ao aspecto formal, pois o que se propõe é a instituição do novo tributo por meio de lei. 
E quanto à cobrança, em especial quando da constatação de atividade penosa, pode-se argumentar que a alíquota SAT atinge empresas cujas atividades envolvem trabalho penoso; observe-se, no entanto, que o caráter contributivo da Previdência Social (artigo 195 e incisos da Constituição Federal e legislação infraconstitucional) e o seu regime de custeio estão lastreados em hipóteses previstas em leis, decretos ou portarias, como são os riscos ambientais do trabalho, que são devidamente regulamentados.

Contudo, quando se trata especificamente do trabalho penoso, não há regulamento, sequer tem conceito legalmente previsto, como já tratamos. Questiona-se: como poderia haver duplo pagamento, como é possível afirmar que há tributação de algo que sequer está regulamentado? E quando tratamos das atividades penosas, ainda que seja ínsito de sua natureza o exercício do labor em situação-limite, sem possibilidade de controle ou amenização, em determinadas atividades e forma de execução ultrapassa-se o limite do risco permitido; quando o empregador cria um risco em nível superior ao permitido, haverá um risco proibido ou incremento do risco permitido, como ensina Guilherme Guimarães Feliciano. ${ }^{507}$

Nessas hipóteses, não há falar em relação de causalidade, e sim em imputação objetiva, em responsabilização objetiva labor ambiental, para ressarcimento social dos danos. Aqui se afasta o nexo naturalístico, pois o nexo será normativo, como explica esse autor.

Trata-se de aplicação de princípios e fundamentos do direito ambiental, como o do poluidor pagador, consubstanciando-os em previsão legal, de tal forma que, em vez de haver reparação de degradação ou poluição ambiental, exista reparação social pelos danos causados aos trabalhadores, na medida em que a Previdência Social é que arca com os ônus decorrentes de mortes, de acidentes ou de doenças do trabalho e deve ser ressarcida.

Nada mais justo que os responsáveis pelos danos causados aos trabalhadores por aqueles que se enriquecem à custa de um "patrimônio social” respondam efetivamente pelos danos; cuida-se, como já dissemos, da aplicação do princípio do poluidor-

${ }^{507}$ FELICIANO, Guilherme Guimarães. Teoria da imputação objetiva no direito penal ambiental brasileiro. São Paulo: LTr, 2005. p. 96-100. 
pagador. Impõe-se ao poluidor, no caso, o empregador, que exigiu tarefas ou condições de trabalho adversas, no limite do risco proibido, que chegaram a provocar até a morte por exaustão, o dever de arcar com as despesas de reparação, de ressarcimento dos benefícios que serão gastos pelos cofres públicos. Assim, o causador dos sinistros, que matam ou mutilam e das moléstias ocupacionais incapacitantes, deve ser o responsável principal pelas consequências de sua ação ou omissão. Nessa observação, relembre-se o ensinamento de Fábio Nusdeo: trata-se aqui da "internalização de custos sociais". 508

Nessa linha, o princípio do poluidor-pagador vem contrabalançar essa imperfeição do mercado, a externalidade, uma vez que sem tal princípio não haveria, de um lado, proteção para a sociedade e, de outro, setores privados - em detrimento de interesses coletivos e/ou difusos - obteriam lucro, repassando determinados custos para terceiros. Assim, se é justo que uma empresa que desmate uma área para obter lenha para suas fornalhas arque com os custos de reflorestamento, visto que a referida empresa é a beneficiária direta com a exploração econômica e causadora do dano, não sendo, portanto, concebível que o contribuinte seja chamado para ficar com o prejuízo material, além dos prejuízos ecológicos que afetam a todos, justo também é que o empregador que submeta alguém a um trabalho que pode levar à morte suporte os custos decorrentes do infortúnio.

Por último, nessa esteira e à luz da imputação objetiva, em caso de acidente do trabalho fatal, quando se verificar por perícia administrativa que naquela atividade houve uma conduta criadora do risco proibido, que incrementou o risco permitido, oriundo da atividade penosa; quando se constatar que houve, por exemplo, exploração desmesurada do trabalho humano, como são os casos de morte por exaustão, a Previdência Social deverá ser ressarcida, conforme deverá estar previsto em lei, mediante cobrança de dívida, sem provocação judicial.

Sabe-se que o Instituto Nacional do Seguro Social (INSS), por meio da Advocacia-Geral da União (AGU), passou a ingressar com ações judiciais exigindo o ressarcimento aos cofres públicos dos valores gastos com a pensão, auxílio-doença e aposentadoria por invalidez; foram escolhidos de início os casos graves, como os de acidentes provocados por motoristas condenados por homicídios dolosos, com cobrança de

\footnotetext{
${ }^{508}$ NUSDEO, Fábio. Curso de economia: introdução ao direito econômico. São Paulo: RT, 2000. p.159.
} 
valores da pensão paga à família da vítima. Medidas assim já eram tomadas no caso de acidentes do trabalho, quando houve negligência da empresa. De acordo com o noticiado, a AGU, no ano de 2011, já havia ajuizado mais de 1.200 ações regressivas previdenciárias, com sentenças procedentes em cerca de $90 \%$ dos feitos. ${ }^{509}$

Não é o que se propõe aqui, pois o exercício de ação já está constitucionalmente garantido; é despiciendo que haja autorização legal para ajuizamento de ações. Pretende-se aqui a proposição de imputação objetiva, para reparação social dos danos, em caso de conduta que adentrou ao risco proibido, causando danos irreversíveis ou a morte do trabalhador. Assim, a empresa deverá ressarcir a Previdência Social, independentemente de provocação judicial; o ressarcimento deverá se dar pela via administrativa.

Trata-se de fazer com que os custos sociais externos que acompanham a produção sejam internalizados, isto é, levados à conta dos agentes econômicos em seus custos de produção, ao mesmo tempo em que os custos assumidos pelos cofres públicos são compensados. Além disso, a medida é pedagógica, pois a reparação ora proposta terá o condão de frear os ânimos voltados à exploração humana, já que deve ser elevada.

Cuida-se também de corrigir a "falha" das externalidades e as consequências labor-ambientais danosas, para que não sejam ignoradas indefinidamente, pois os trabalhadores são expostos às condições desumanas e labutam como se fossem máquinas, que são substituídas por outras, até que "apresentem defeito" e sejam descartadas.

$\mathrm{E}$, como dito anteriormente, não adianta criar um novo adicional, monetizar a saúde do trabalhador, pois isso sai barato para o capital e nada resolve no sentido da proteção da saúde e da integridade física e mental do trabalhador.

Este é o objetivo principal que se pretende atingir com a reparação social dos danos ora proposta.

${ }^{509}$ Folha de S. Paulo, Caderno Mercado, 28 set. 2011, B1. 


\section{CONCLUSÕES}

Como expusemos, decorridas mais de duas décadas da entrada em vigor da Constituição Federal, o trabalho penoso ainda não foi regulamentado, ao contrário do exercido em condições de insalubridade e de periculosidade.

As normas em vigor não preveem qualquer forma de compensação ao trabalhador que desempenha atividades penosas, como a aposentadoria especial; esse benefício permitiria ao obreiro trabalhar por menos tempo do que aqueles que não se expõem às condições adversas. Além disso, a legislação premia o empregador com redução das alíquotas do Grau de Incidência de Incapacidade Laborativa - Riscos Ambientais do Trabalho - GIIL-RAT; a possibilidade da redução da alíquota está diretamente vinculada à inexistência de óbitos de trabalhadores e de concessão de benefícios previdenciários por invalidez permanente, bem como de baixa taxa de rotatividade de mão de obra, mediante a aplicação do Fator Acidentário de Prevenção (FAP).

Não é crível que esse Fator, efetivamente, esteja retratando uma realidade de redução de acidentes e doenças do trabalho, pois as informações são prestadas unilateralmente pelo empresariado, sem que haja qualquer fiscalização oficial. Os dados são obtidos dos PCMSO e PPRA "perfeitos" apresentados pelas empresas. E os números do Nexo Técnico Epidemiológico (NTEP) demonstram o contrário do que revela o FAT.

Para que se possa atingir a efetiva reparação dos danos decorrentes de doenças e acidentes do trabalho, com ressarcimento social dos danos, e, mais que isso, para que seja alcançada a tão desejada prevenção dos riscos no meio ambiente de trabalho, de forma que os trabalhadores não sejam submetidos a condições laborais adversas, penosas, que culminam não raras vezes em óbito, é preciso, em primeiro lugar, revogar a legislação que instituiu o FAP.

Além disso, como forma de terminar de vez com a multiplicidade de fontes e de dados, oriundos de vários órgãos públicos que colidem entre si, acerca dos registros das doenças e acidentes do trabalho, é preciso instituir um Cadastro Nacional Unificado dessas ocorrências. 
Os princípios ambientais da prevenção ou da atuação preventiva e da precaução devem fazer parte de políticas públicas, em todos os poderes públicos, de todas as unidades da Federação.

E, no que tange ao trabalho penoso, nova legislação deveria prever que à fiscalização incumbiria a realização de perícia administrativa, por ramo de atividade econômica, que atestaria a existência, em determinadas atividades, de trabalho penoso.

Nesse passo, nas empresas em que se constatar o aumento do número de acidentes, ocorrência de acidente fatal, bem como de trabalho penoso, o que se propõe não é simplesmente deixar de haver a redução da alíquota GIIL-RAT, como ocorre hoje, e sim de elevar a taxação, como forma indenização punitiva, revertida à Previdência Social.

Dessa maneira, à luz da imputação objetiva, em caso de acidente do trabalho fatal, quando se verificar por perícia administrativa que naquela atividade houve uma conduta criadora do risco proibido, que incrementou o risco permitido, oriundo da atividade penosa; quando se constatar que houve, por exemplo, exploração desmesurada do trabalho humano, como são os casos de morte por exaustão, a Previdência Social deverá ser ressarcida, conforme previsão legal, mediante cobrança de dívida, sem necessidade de provocação judicial.

O caminho a ser trilhado para a efetiva proteção da saúde e da integridade física e mental do trabalhador não é, definitivamente, a monetização do risco; a criação de adicionais sai barato para o empregador: é mais econômico arcar com tais custos do que com equipamentos de proteção e tecnologias que propiciem um meio ambiente de trabalho sadio e equilibrado.

Contudo, como foi exposto, no caso do trabalho penoso estão envolvidos aspectos ambientais e temporais que apontam para uma situação-limite, sem possibilidade de controle e amenização, porque certamente causará danos à saúde do trabalhador. Em decorrência, os trabalhadores terão direito à percepção de benefícios concedidos pela Previdência Social, custeados por toda a sociedade. 
Por essa razão, à luz do princípio do poluidor-pagador e da imputação objetiva, o causador dos danos, o empregador, deverá ressarcir a Previdência Social, independentemente de provocação judicial, como forma de concretizar a reparação social dos danos. 


\section{REFERÊNCIAS BIBLIOGRÁFICAS}

ABE, Maria Inês Miya. A seguridade social em função dos direitos humanos. 2007. Faculdade de Direito, Universidade de São Paulo, São Paulo.

ALBORNOZ, Suzana. O trabalho na balança dos valores. Para onde vai o mundo do trabalho?. Revista Cult, São Paulo, ano 12, n. 139, set. 2009.

ANJOS, Luiz Antonio dos; FERREIRA, João Alberto. A avaliação da carga fisisiológica de trabalho na legislação brasileira deve ser revista! O caso da coleta de lixo domiciliar no Rio de Janeiro. Cad. Saúde Pública, Rio de Janeiro, v. 16, n. 3, jul.-set. 2000. Disponível em: $\quad<$ http://www.scielosp.org/scielo.php?script=sci_arttext\&pid= $\mathrm{S} 010211 \mathrm{X} 2000000300026 \& \operatorname{lng}=\mathrm{pt} \& \mathrm{nrm}=\mathrm{isso}>$.

ANTUNES, Ricardo. A desconstrução do trabalho e a perda de direitos sociais. O direito e o processo do trabalho na sociedade contemporânea. Coordenador Roberto Parahyba de Arruda Pinto. São Paulo: LTr, 2005.

- Adeus ao trabalho?: ensaio sobre as metamorfoses e a centralidade do mundo do trabalho. São Paulo: Cortez, 2010.

—. Os dilemas do trabalho no limiar do século 21. Dossiê: Qual é o sentido do trabalho? Revista Cult, São Paulo, n. 139, p. 54-56, set. 2009.

ARENDT, Hannah. A condição humana. Rio de Janeiro: Forense Universitária, 1991.

ASSUNÇÃO, Ada Ávila; ANTUNES LIMA, Francisco de Paula. A contribuição da ergonomia para a identificação, redução e eliminação da nocividade do trabalho. In: MENDES, René et al. Patologia do trabalho. São Paulo: Atheneu, 2005.

BALLONE, G. J. Síndrome de Burnout. Disponível em: <http://www.psiqweb.med.br>.

BARBOSA, Cristiane Maria Galvão. Avaliação cardiovascular e respiratória em um grupo de trabalhadores cortadores de cana-de-açúcar queimada no estado de São 
Paulo. 2010. Tese (Doutorado em Ciências. Programa de Pneumologia) - Faculdade de Medicina da Universidade de São Paulo, São Paulo.

BARRETO, Margarida Maria Silveira. Violência, saúde e trabalho: uma jornada de humilhações. São Paulo: Educ, 2006.

BATTAGLIA, Felice. Filosofia do trabalho. São Paulo: Saraiva, 1958.

BELTRAN, Ari Possidônio. A responsabilidade civil do empregador. Revista de Direito do Trabalho, São Paulo, v. 30, n. 115, jul.-set. 2004.

BENJAMIN, Antonio Herman V. O princípio poluidor-pagador e a reparação do dano ambiental. In: (Coord.). Dano ambiental: prevenção, reparação e repressão. São Paulo: RT, 1993.

BÍBLIA SAGRADA. São Paulo: Edição Claretiana, 1977.

BLACKBURN, Robin. A construção do escravismo no Novo Mundo. Rio de Janeiro: Record, 2003.

BONAVIDES, Paulo. Curso de direito constitucional. São Paulo: Malheiros, 2000.

BOTTON, Alain de. Os prazeres e desprazeres do trabalho: reflexões sobre a beleza e o horror do ambiente de trabalho moderno. Rio de Janeiro: Rocco, 2009.

BRANCO, Anadergh Barbosa; ALBUQUERQUE-OLIVEIRA, Paulo Rogério. Epidemiologia das licenças do trabalho por doenças mentais no Brasil, 1999-2002. Disponível em: $<$ http://www.prt18.mpt.gov.br/eventos/2004/saude_mental/anais/artigos/3.pdf $>$.

BRANDÃO, Cláudio. Poder do empregador e exclusão da culpabilidade criminal. Revista da Esmape, Recife, v. 5, n. 11, p. 95-113, jan.-jun. 2000. 
BRITO FILHO, José Cláudio Monteiro de. Trabalho decente: análise jurídica da exploração, trabalho escravo e outras formas de trabalho indigno. São Paulo: LTr, 2010.

BRUSCHINI, Cristina; LOMBARDI, María Rosa. Brasil: La calidad del empleo de las mujeres. Continuidades y cambios. Más y Mejores Empleos para las Mujeres? La experiência de los países del Mercosul y Chile. Disponível em: $<$ http://www.oitchile.cl/pdf/publicaciones/igu/igu021.pdf $>$.

BUCHALLA, Cassia Maria. A classificação internacional de funcionalidade, incapacidade e saúde. Acta Fisiátrica, São Paulo, 10(1): 29-31, 2003.

CARVALHO, Valdir Jose da Silva de et al. Acidente do trabalho. responsabilidade do empregador por dolo ou culpa, perante a sociedade. Revista do Ministério Publico do Trabalho, Brasília, v. 4, n. 8, set. 1994.

CAVALLO, Achiles Augustus. Seguro de acidente do trabalho - SAT - Apuração do grau de risco para contribuintes com diversos estabelecimentos. Revista Dialética de Direito Tributário, São Paulo, n. 31, abr. 1998.

CECILIA, Silvania Louzada Lamattina. Responsabilidade do empregador por danos à saúde do trabalhador. 2007. Dissertação (Mestrado) - Faculdade de Direito, Universidade de São Paulo, São Paulo, 2007.

CHAGAS, Ana Maria de Resende. A política de assistência e a participação social: o caso do Conselho Nacional de assistência social (CNAS). Brasília: IPEA, dez. 2003.

COMPARATO, Fábio Konder. A afirmação histórica dos direitos humanos. São Paulo: Saraiva, 2003.

Fundamento dos direitos humanos. In: MARCILIO, Maria Luiza e o (Coord.). Cultura dos direitos humanos. São Paulo: LTr, 1998.

CÓDIGO CIVIL BRASILEIRO. Disponível em: <http://www.planalto.gov.br>. 
CONSOLIDAÇÃO DAS LEIS DO TRABALHO. Disponível em: $<$ http://www.planalto.gov.br>.

CONSTITUIÇÃO DA REPÚBLICA FEDERATIVA DO BRASIL. Disponível em: $<$ http://www.planalto.gov.br $>$

CORDEIRO, Ricardo et al. Subnotificação de acidentes do trabalho não fatais em Botucatu, SP, 2002. Rev. Saúde Pública, São Paulo, v. 39, n. 2, abr. 2005. Disponível em:

$<$ http://www.scielo.br/scielo.php?script=sci_arttext\&pid=S003489102005000200017 $\& \operatorname{lng}=$ en\&nrm=iso $>$ Acesso em: 18 ago. 2012.

CORREIA, Marcus Orione Gonçalves. Teoria e prática do poder de ação na defesa dos direitos sociais. São Paulo: LTr, 2002.

CORREIA, Rogério Santos. A evolução da responsabilidade do empregador nos acidentes do trabalho. Revista de Previdência Social, São Paulo, v. 18, n. 166, set. 1994.

DABUL, Alessandra. A chamada flexibilização das alíquotas da contribuição ao Seguro Acidente do Trabalho - SAT. Revista Dialética de Direito Tributário, São Paulo, ago. 2007.

DEJOURS, Christophe. A loucura do trabalho: estudo de psicopatologia do trabalho. São Paulo: Cortez, 1988.

—. Entre o desespero e a esperança: como reencantar o trabalho? Dossiê Qual é o sentido do trabalho? Revista Cult, São Paulo, n. 139, set. 2009.

DE LA CUEVA, Mario. Derecho Mexicano Del Trabajo, 1949, v. 1.

DE MASI, Domenico. Desenvolvimento sem trabalho. São Paulo: Esfera, 1999.

O ócio criativo. Rio de Janeiro: Sextante, 2000. 
DE SETA, Marismary Horsth; REIS, Lenice G. da Costa. As vigilâncias do campo da saúde, o risco como conceito fundamental e a caracterização dos seus processos de trabalho. Qualificação de Gestores do SUS. Disponível em: $<$ http://www.medtrab.ufpr.br/arquivosparadownload/PoliticaspublicaemSaudeeTraba lho/7vigilancisrisco.pdf>. Acesso em: 4 nov. 2012.

DERANI, Cristiane. Direito ambiental econômico. São Paulo: Saraiva, 2008.

DRAGONI, José Fausto. Segurança, saúde e meio ambiente em obras: diretrizes voltadas à gestão eficaz de segurança e saúde no trabalho, segurança patrimonial e meio ambiente em obras de pequeno, médio e grande porte. São Paulo: LTr, 2006.

DUPAS, Gilberto. A lógica da economia global e a exclusão social. Estudos Avançados, São Paulo, v. 12, n. 34, set.-dez. 1998.

EUZEBY, Alain. Las cotizaciones sociales y el empleo: reduccion o racionalizacion? Revista Internacional del Trabajo, Ginebra, v. 114, n. 2, 1995.

FALCÃO, Felipe Hack de Barros. Os impactos gerados pelo fator acidentário de prevenção e o nexo epidemiológico nas relações de emprego. LTr: Legislação do Trabalho, Suplemento trabalhista, São Paulo, v. 44, n. 46, 2008.

FELDMAN, Sergio Alberto. Trabalho e escravidão no Judaísmo bíblico. Arquivo Maaravi - Revista Digital de Estudos Judaicos da UFMG, v. 1, n. 2, mar. 2008. Disponível em: <https://www.ufmg.br/nej/maaravi/artigosergiofeldman1-torah.html>.

FELICIANO, Guilherme Guimarães. Teoria da imputação objetiva no direito penal ambiental brasileiro. São Paulo: LTr, 2005.

FERNANDES, Fábio. Meio ambiente do trabalho e a dignidade do cidadão trabalhador. In: PIOVESAN, Flávia; CARVALHO, Luciana Paula Vaz de (Coord.). Direitos humanos e direito do trabalho. São Paulo: Atlas, 2010.

- Meio ambiente geral e meio ambiente do trabalho: uma visão sistêmica. São Paulo: LTr, 2009. 
FERRARI, Irany. O trabalho perigoso mata milhões de pessoas e custa bilhões de reais. LTr: Suplemento Trabalhista, São Paulo, ano 39, n. 156, 2003.

FERREIRA, Ivette Senise. Do meio ambiente do trabalho e sua relação com os direitos fundamentais da pessoa humana. Revista do Advogado, São Paulo, v. 24, n. 76, jun. 2004.

FERREIRA, Mário César; FREIRE, Odaleia Novais. Carga de trabalho e rotatividade na função de frentista. Disponível em: $<$ http://www.scielo.br/pdf/rac/v5n2/v5n2a09.pdf >. Acesso em: 9 nov. 2012

FIGUEIREDO, Guilherme José Purvin de. Direito ambiental e a saúde dos trabalhadores. 2. ed. São Paulo: LTr, 2007.

FISCHER, Frida Marina. Organização do trabalho em turnos e noturno. Seminário realizado na Fundacentro, 20 ago. 2012.

FLEURY, Afonso Carlos Correia; VARGAS, Nilton et al. Organização do trabalho: uma abordagem interdisciplinar: sete casos brasileiros para estudo. São Paulo: Atlas, 1983.

FOLHA DE SÃO PAULO. Caderno Carreiras e Empregos. 9 out. 2011.

—. Caderno Negócios e Carreiras. 7 out. 2012.

—. Caderno Mercado, B1, 28 set. 2011.

FON, Antonio Carlos. Trabalho escravo. Crônicas da infâmia. Revista da CUT, São Paulo, ano I, n. 2, mar. 2004.

FÓRUM SOCIAL MUNDIAL 2003. Anais da oficina de trabalho escravo: uma chaga aberta. Brasília: OIT, 2003.

FREITAS JR., Antonio Rodrigues de. Direitos sociais e eficácia horizontal dos direitos fundamentais: possíveis consequências práticas para o exercício do poder disciplinar 
do empregador. In: SÉGUIN, Elida; FIGUEIREDO, Guilherme José Purvin de (Coord.). Meio ambiente do trabalho. Rio de Janeiro: GZ Verde Editora, 2010.

- Efetivação dos direitos sociais como condição da democracia (ou, sobre os riscos de uma nova Assembleia de Revisão Constitucional). In: CORREIA, Marcus Orione Gonçalves (Org.). Curso de direito do trabalho: teoria geral do direito do trabalho. São Paulo: LTr, 2007. v. 1. (Coleção Pedro Vidal Neto.)

— Tópicos da agenda protecionista na nova Constituição brasileira. Revista Jurídica do Trabalho, ano II, n. 5, abr.-jun. 1989.

FREITAS, Maria Ester de; HELOANI, Roberto; BARRETO, Margarida. Assédio moral no trabalho. São Paulo: Cengage Learning, 2009.

FRIEDMANN, George; NAVILLE, Pierre (Org.). Tratado de sociologia do trabalho. Rio de Janeiro: Cultrix, 1973.

FUNDACENTRO. Aposentadoria especial como instrumento de proteção à segurança e saúde dos trabalhadores. I Seminário sobre Aposentadoria Especial como um instrumento de proteção à saúde do trabalhador. Coordenação técnica de Cristiane Queiroz Barbeiro Lima. São Paulo, 2010.

GERALDI, Cláudia Maria de Paula Eduardo et al. Estudo de caso: a questão da queima da palha da cana-de-açúcar: a difícil conciliação entre produção ambiental e desenvolvimento (proibição x autorização) - dois aspectos do Estado em Juízo. Direito ambiental e as funções essenciais à justiça: o papel da advocacia de estado e da defensoria pública na proteção do meio ambiente. Coordenação de Antonio Herman Benjamin e Guilherme José Purvin de Figueiredo. São Paulo: RT, 2011.

GERMANI, Gianitalo. Seguro de acidentes do trabalho: SAT; evolução legislativa e aspectos de legalidade e constitucionalidade. Síntese Trabalhista, Porto Alegre, v. 10, n. 123 , set. 1999. 
GLINA, D. M. R.; Rocha, L. E. Exigências do trabalho, prevalência de dor muscular e de sintomas de estresse em estagiários do setor de cobrança de um banco internacional. Revista de Terapia Ocupacional, São Paulo, v. 14, n. 1, 2003.

GOMES, Jorge da Rocha. Trabalho da criança e do adolescente no corte da cana-deaçúcar. Revista Brasileira de Saúde Ocupacional, São Paulo, v. 26, 2001.

GORZ, André. Crítica da divisão do trabalho. São Paulo: Martins Fontes, 2001.

GRANDE ENCICLOPÉDIA LAROUSSE CULTURAL. São Paulo: Larousse, 1995. Nova Cultural, 1998.

GRAU, Eros Roberto. A ordem econômica na Constituição de 1988. São Paulo: Malheiros, 2010.

GUARNIERI, Bruno Marcos. Meio ambiente do trabalho: prevenção dos infortúnios laborais, dignificação do trabalho e responsabilidade civil do empregador. LTr: Revista Legislação do Trabalho, São Paulo, v. 71, n. 12, dez. 2007.

GUELLER, Marta Maria R. Penteado. A aposentadoria e as recentes alterações introduzidas na legislação previdenciária. In: FREUDENTHAL, Sergio Pardal (Coord.). A Previdência Social hoje: homenagem a Anníbal Fernandes. São Paulo: LTr, 2004..

GUÉRIN, F. et al. Compreender o trabalho para transformá-lo: a prática da ergonomia. São Paulo: Blucher: Fundação Vanzolini, 2001.

GUSTIN, Miracy Barbosa de Sousa. Das necessidades humanas aos direitos: ensaio de sociologia e filosofia do direito. Belo Horizonte: Del Rey, 2009.

HOLANDA FERREIRA, Aurélio Buarque de. Novo dicionário Aurélio. 1. ed. 12. impressão. Rio de Janeiro: Nova Fronteira.

HOBSBAWM, Eric. A era do capital: 1848-1875. São Paulo: Paz e Terra, 2012. 
IBANHES, Lauro César Ibanhes. Aspectos organizacionais do trabalho informal urbano. Disponível

em: $<$ http://www.assis.unesp.br/encontrosdepsicologia/ANAIS_DO_XIX_ENCONTRO/ 46_Lauro_Cesar_Ibanhes.pdf $>$.

JARDIM, Eduardo Marcial Ferreira. Inconstitucionalidades que permeiam a contribuição social para o seguro de acidentes do trabalho - SAT. Revista Dialética de Direito Tributário, São Paulo, n. 31, abr. 1998.

JORNADAS DE DIREITO CIVIL I, III, IV e V: enunciados aprovados. Coordenador científico Ministro Ruy Rosado de Aguiar Júnior. Brasília: Conselho da Justiça Federal, Centro de Estudos Judiciários, 2012. Disponível em: $<$ http://www.stj.jus.br/publicacaoseriada/index.php/jornada $>$.

KANT, Immanuel. Fundamentação da metafísica dos costumes. Lisboa: Edições 70, 2003.

KWITKO, Airton. FAP - Fator acidentário de prevenção. Revista de Previdência Social, São Paulo, v. 32, n. 329, abr. 2008.

LAAT, Erivelton Fontana de; VILELA, Rodolfo Andrade de Gouveia. A análise ergonômica do trabalho na colheita da cana-de-açúcar: proposta para redução do desgaste físico do trabalhador. Livro de Memórias do III Congresso Científico Nortenordeste - CONAFF. Disponível em: $<$ http://www2.sanny.com.br/pdf_eventos_conaff/Artigo06.pdf $>$.

LACAZ, Francisco Antônio de Castro. Qualidade de vida no trabalho e saúde/doença. Ciência e Saúde Coletiva, n. 5, 2000.

LACERDA, Nadia Demoliner. Segurança e saúde do trabalhador: para onde vamos? O debate nacional sobre a concepção preventiva do novo seguro de acidente. São Paulo: LTr, 2011.

LANGER, André. O trabalho como essência do homem. Revista Vinculando, Ciudad de México, ago. 2004. Disponível em: <http://vinculando.org>. 
LEITE, Celso Barroso. Considerações sobre Previdência Social. In: FREUDENTHAL, Sergio Pardal (Coord.). A Previdência Social hoje: homenagem a Anníbal Fernandes. São Paulo: LTr, 2004.

LEONARDI, Renzo. Meio ambiente do trabalho e a responsabilidade civil e penal das empresas. Cadernos Jurídicos, Escola Paulista da Magistratura, São Paulo, v. 3, n. 8, mar.-abr. 2002.

LEPORE, Michele; MEDINA, Anna. Il diritto alla sicurezza sul lavoro. Roma: Lavoro, 1984.

LIMA, Alceu Amoroso. O problema do trabalho. Rio de Janeiro: Livraria Agir Editora, 1947.

LIMA, Francisco de P. A. Norma e atividade humana: modelos dinâmicos da prescrição e historicidade das situações de trabalho. In: DIEESE/CESIT (Org.). Trabalho $e$ abordagem pluridisciplinar: estudos Brasil, França e Argentina. São Paulo: Dieese e Campinas: CESIT, 2005.

LIMA, Francisco Meton Marques de. As implicações recíprocas entre o meio ambiente e o custo social do trabalho. Revista LTr: Legislação do Trabalho, v. 71, n. 3, mar. 2007.

LINHART, D. A caminho da desumanização. Le Monde Diplomatique, 2006. Dossiê Futuro do Trabalho. Disponível em: <http://diplo.uol.com.br/imprima1265>.

LOPEZ CACHERO, Manuel. La prevención de riesgos laborales en el sector electrico espanol. Revista do Trabajo y Seguridad Social, Madrid, n. 9, ene.-mai. 1993.

LORENZETTI, Ari Pedro. A penosidade no direito do trabalho. Revista Trabalhista: direito e processo, Rio de Janeiro, v. 6, n. 21, jan.-mar. 2007.

LOTTO, Luciana Aparecida. Ação civil pública trabalhista contra o trabalho escravo no Brasil. São Paulo: LTr, 2008.

LUFT, Lya. Trabalhar e sofrer. Veja, 20 jan. 2010. 
MAENO, Maria; CARMO, José Carlos do. Saúde do Trabalhador no SUS: aprender com o passado, trabalhar o presente, construir o futuro. São Paulo: Hucitec, 2005.

; VILELA, Rodolfo Andrade de Gouveia. Reabilitação profissional no Brasil: elementos para a construção de uma política pública. Revista Brasileira de Saúde Ocupacional, São Paulo, p. 88, 2010.

MARCÍLIO, Maria Luiza e o. (Coord.). A Constituição brasileira de 1988 e os tratados internacionais de proteção dos direitos humanos. Cultura dos direitos humanos. São Paulo: LTr, 1998.

MARCUSE, Herbert. Cultura e sociedade. São Paulo: Paz e Terra, 1998. v. 2.

MARQUES, Christiani. A proteção ao trabalho penoso. São Paulo: LTr, 2007.

MARTINEZ, Maria Carmen. As relações entre a satisfação com aspectos psicossociais no trabalho e a saúde do trabalhador. 2002. Dissertação (Mestrado) - FSP - Faculdade de Saúde Pública, São Paulo.

MARTINEZ, Wladimir Novaes. Aposentadoria especial. São Paulo: LTr, 2010.

MARX, Karl. Manuscritos econômico-filosóficos. Primeiro manuscrito - Trabalho Alienado. Disponível em: $<$ http://www.marxists.org/portugues/marx/1844/manuscritos/cap01.htm>.

—. Processo de trabalho e processo de produzir mais-valia. O capital: crítica da economia política. 6. ed. Rio de Janeiro: Civilização Brasileira, 1980. livro 1, v. 1. - Trabalho assalariado e capital. São Paulo: Global, 1980.

MELLO, Marco Aurélio Mendes de Farias. Segurança do trabalho, insalubridade, amplitude de responsabilidade do empregador. Revista de Direito do Trabalho, São Paulo, v. 13, n. 73, maio-jun. 1988. 
MELO, Raimundo Simão de. Ação civil pública na justiça do trabalho. São Paulo: LTr, 2008 .

Direito ambiental do trabalho e a saúde do trabalhador: responsabilidades legais, dano material, dano moral, dano estético, indenização pela perda de uma chance, prescrição. São Paulo: LTr, 2008.

MENDES, Almara Nogueira. Nova forma de escravidão urbana: trabalho de imigrantes. Revista do Ministério Público do Trabalho, ano XIII, n. 26, set. 2003.

MINAYO GOMES, Carlos et al. (Org.). Saúde do trabalhador na sociedade brasileira contemporânea. Rio de Janeiro: Fiocruz, 2011.

MINISTÉRIO DO TRABALHO E EMPREGO. Introdução à higiene ocupacional. São Paulo: Fundacentro, 2004.

MIRANDA, Carlos Roberto. Programa de condições e meio ambiente de trabalho na indústria da construção: auditoria, inspeção do trabalho e controle social. CIPA: caderno informativo de prevenção de acidentes, v. 26, n. 304, mar. 2005.

MORAES, Maria Celina Bodin de. O conceito de dignidade humana: substrato axiológico e conteúdo normativo. In: SARLET, Ingo Wolfgang (Org.). Constituição, direitos fundamentais e direito privado. Porto Alegre: Livraria do Advogado, 2006.

MORAES, Maria Isabel Cueva. A negociação coletiva ambiental trabalhista e seus frutos. 2008. Dissertação (Mestrado) - Faculdade de Direito da USP, São Paulo.

MORAIS, Leonardo Bianchini. O fator acidentário previdenciário (FAP) e o nexo técnico epidemiológico (NTEP). Revista de Previdência Social, São Paulo, v. 32, n. 328, mar. 2008.

MORENO, Cláudia Roberta de Castro; FISCHER, Frida Marina; ROTENBERG, Lúcia. A saúde do trabalhador na sociedade 24 horas. Disponível em: $<$ https://www.seade.gov.br/produtos/spp/v17n01/v17n01_04.pdf $>$. 
NASCIMENTO, Amauri Mascaro. Curso de direito do trabalho: história e teoria geral do direito do trabalho: relações individuais e coletivas do trabalho. 22. ed. rev. e atual. São Paulo: Saraiva, 2007.

—. O custo social e a economia do país. Revista de Direito do Trabalho, São Paulo, v. 26, n. 98, abr.-jun. 2000.

NUSDEO, Fábio. Curso de economia: introdução ao direito econômico. São Paulo: RT, 2000.

OBSERVATÓRIO Social em Revista. Trabalho escravo no Brasil, n. 6, jun. 2004.

OLIVEIRA, Francisco Antônio de. Direito do trabalho. São Paulo: RT, 1993.

OLIVEIRA, Sebastião Geraldo de. Aspectos atuais da responsabilidade jurídica em acidentes do trabalho. 24. ${ }^{\circ}$ Encontro Presencial do Fórum Acidentes do Trabalho: Análise, Prevenção e Aspectos Associados. São Paulo: Faculdade de Saúde Pública da Universidade de São Paulo, jun. 2011. Disponível em: $<$ http://www.moodle.fmb.unesp.br/mod/resource/view.php?id=5334>.

—. Indenizações por acidente do trabalho ou doença ocupacional. 5. ed. rev., ampl. e atual. São Paulo: LTr, 2009.

—. Proteção jurídica à saúde do trabalhador. 5. ed. rev. ampl. e atual. São Paulo: LTr, 2010.

PADILHA, Norma Sueli. Do meio ambiente de trabalho equilibrado. São Paulo: LTr, 2002.

PEREIRA, Alexandre Demetrius. Tratado de segurança e saúde ocupacional: aspectos técnicos e jurídicos. São Paulo: LTr, 2005.

PIMENTA, João de Deus et al. Saúde e produtividade. Salvador: Fundação Emílio Odebrecht, 1983. 
PINTO, Airton Pereira. Direito do trabalho, direitos humanos sociais e a Constituição Federal. São Paulo: LTr, 2006.

PINTO, José Augusto Rodrigues. Breves cogitações sobre a responsabilidade no direito do trabalho. Revista de Direito do Trabalho, São Paulo, v. 31, n. 117, jan.-mar. 2005.

PIOVESAN, Flávia. A Constituição brasileira de 1988 e os tratados internacionais de proteção dos direitos humanos. In: MARCÍLIO, Maria Luisa e o (Coord.). Cultura dos direitos humanos. São Paulo: LTr, 1998.

—. Temas de direitos humanos. São Paulo: Max Limonad, 1998.

PRADO, Erlan José Peixoto do. A ação civil pública e sua eficácia no combate ao trabalho em condições análogas à de escravo: o dano moral coletivo. In: VELLOSO, Gabriel; FAVA, Marcos Neves (Coord.). Trabalho escravo contemporâneo: o desafio de superar a negação. São Paulo: LTr, 2006. .

PRADO JUNIOR, Caio. História econômica do Brasil. São Paulo: Brasiliense, 1987.

RAMALHO, Carolina Calmon. Viver na baia: dimensões psicossociais da saúde e do controle no trabalho de teleatendimento. Cadernos de Psicologia Social e do Trabalho, São Paulo, v. 11, n. 1, 2008.

RAMOS, Yara Chaves Galdino. O direito ao trabalho e seu fundamento constitucional. 2005. Tese (Doutorado) - Faculdade de Direito, Universidade de São Paulo, São Paulo, 2005.

REBOUÇAS, Antonio José de Arruda. A aposentadoria especial e a desconstrução de direitos sociais, no regime geral da previdência social. I Seminário sobre aposentadoria especial como um instrumento de proteção à segurança e saúde do trabalhador. Coordenação técnica de Cristiane Queiroz Barbeiro Lima. São Paulo, Brasil, 25 setembro 2008; São Paulo: Fundacentro, 2010.

et al. Insalubridade: morte lenta no trabalho: a insalubridade no Brasil. São Paulo: Oboré, 1989. 
REVISTA DO BRASIL. São Paulo: Atitude Gráfica Editora, n. 44, fev. 2010.

—. São Paulo: Atitude Gráfica Editora, n. 59, maio 2011.

RIBEIRO, Helena. Queimadas de cana-de-açúcar no Brasil: efeitos à saúde respiratória. Rev. Saúde Pública, 42(2), p. 375, 2008.

RIBEIRO, Herval Pina; LACAZ, Francisco A. de Castro. Agentes físicos e doenças. São Paulo: Departamento Intersindical de Estudos e Pesquisas de Saúde e dos Ambientes de Trabalho - DIESAT, 1984.

—. Incapacidade, trabalho e Previdência Social. São Paulo: DIESAT, 1984.

—. Poeiras e doenças pulmonares. São Paulo: DIESAT, 1984.

RIBEIRO, Juliana de Oliveira Xavier; HORVATH JÚNIOR, Miguel. FAP: Um novo método para a redução de acidentes do trabalho. Revista de Direito Social, Sapucaia do Sul, v. 8, n. 30, abr.-jun. 2008.

ROCHA, Marco Aurélio de Oliveira. Da constitucionalidade do SAT. Revista Tributária e de Finanças Públicas, São Paulo, v. 8, n. 33, jul.-ago. 2000.

ROUSSEAU, Jean-Jacques. A origem da desigualdade entre os homens. São Paulo: Escala, 2007.

SALOMÃO, Karina Novah. O acidente do trabalho e sua reparação. 2003. Dissertação (Mestrado) - Faculdade de Direito, Universidade de São Paulo, São Paulo.

SANTANA, Vilma Sousa et al. Acidentes de trabalho: custos previdenciários e dias de trabalho perdidos. Revista Saúde Pública, São Paulo, v. 40, n. 6, 2006.

SANTOS, Darcio Francisco dos. Contribuição previdenciária para o seguro de acidentes de trabalho - SAT - Ilegalidade do Decreto n. 2.173/97. Revista Dialética de Direito Tributário, São Paulo, n. 26, nov. 1997. 
SANTOS, Enoque Ribeiro dos. A função social do contrato, a solidariedade e o pilar da modernidade nas relações de trabalho. São Paulo: LTr, 2003.

—. Responsabilidade objetiva e subjetiva do empregador em face do novo Código Civil. 2. ed. rev. e ampl. São Paulo: LTr, 2008.

SANTOS, Ronaldo Lima dos. A escravidão por dívidas nas relações de trabalho no Brasil contemporâneo. Revista do Ministério Público do Trabalho, São Paulo: LTr, ano XIII, n. 26, 2003.

SARLET, Ingo Wolfgang. A eficácia dos direitos fundamentais. 7. ed. rev., atual. e ampl. Porto Alegre: Livraria do Advogado, 2007.

—. Dignidade da pessoa humana e direitos fundamentais na Constituição Federal de 1988. 2. ed. rev. e ampl. Porto Alegre: Livraria do Advogado, 2002.

SATO, Leny. Abordagem psicossocial do trabalho penoso: estudo de caso de motoristas de ônibus urbano. 1991. Dissertação (Mestrado) - Pontifícia Universidade Católica de São Paulo.

. A representação social do trabalho penoso. In: SPINK, M. J. P. (Org.). O conhecimento no cotidiano: as representações sociais na perspectiva da psicologia social. São Paulo: Brasiliense, 1993.

Conceito de trabalho penoso. Revista CIPA, São Paulo, v. 15, n. 179, p. 41, 1994.

SCHIAVI, Mauro. Aspectos polêmicos do acidente de trabalho: responsabilidade objetiva do empregador pela reparação dos danos causados ao empregado: prescrição. $L T r$ : Revista Legislação do Trabalho, São Paulo, v. 70, n. 5, maio 2006.

SCLIAR, Moacyr. História do conceito de saúde. Disponível em: $<$ http://www.scielo.br/pdf/physis/v17n1/v17n1a03.pdf $>$.

SCOPINHO, Rosemeire Aparecida; EID, Farid; VIAN, Carlos Eduardo de Freitas; SILVA, Paulo Roberto Correia da. Novas tecnologias e saúde do trabalhador: a mecanização 
do corte da cana-de-açúcar. Cad. Saúde Pública, Rio de Janeiro, 15(1), p. 148, jan.mar. 1999.

SENTO-SÉ, Jairo Lins de Albuquerque. Trabalho escravo no Brasil. São Paulo: LTr, 2001.

SILVEIRA, Edilene Aparecida Araújo da; ROBAZZI, Maria Lúcia do Carmo Cruz; LUÍS, Margarita Antonia Villar. Varredores de rua: acidentes de trabalho ocorridos na cidade de Ribeirão Preto, Estado de São Paulo, Brasil. Rev. Latino-Americana de Enfermagem, Ribeirão Preto, v. 6, n. 1, p. 71-79, jan. 1998.

SILVA, Cristiane Ribeiro da. Acidente do trabalho e responsabilidade civil do empregador. LTr: Revista Legislação do Trabalho, São Paulo, v. 71, n. 4, abr. 2007.

SILVA, Edith Seligmann. Crise econômica, trabalho e saúde mental. In: ANGERAMICAMON, Valdemar Augusto (Org.). Crise, trabalho e saúde mental no Brasil. São Paulo: Traço, 1986. v. 4.

SILVA, Edson Braz da. Responsabilidade civil do empregador nos casos de doenças ocupacionais. Revista do Ministério Público do Trabalho, Brasília, v. 16, n. 31, mar. 2006.

SILVA, José Afonso da. Curso de direito constitucional positivo. São Paulo: Malheiros, 1995.

SILVA, José Antônio Ribeiro de Oliveira. A saúde do trabalhador como um direito humano. Revista do Tribunal Regional do Trabalho da 15. ${ }^{a}$ Região, n. 31, p. 119$120,2007$.

A saúde do trabalhador na Constituição Federal e na legislação infraconstitucional - avaliação crítica. Disponível em: <http://camat.com.br/arquivos/artigos/artigo 
saude_do_trabalhador_na_cf_analise_critica_anamatra.pdf $>$. Acesso em: 3 ago. 2012.

SILVA, Luciene Regina Pinheiro da; NOGUEIRA, Marta Cristina de Jesus Albuquerque; DURANTE, Luciane Cleonice; LAMBERT, José Antonio. Risco de exposição e a saúde do trabalhador em uma carvoaria no município de Sinop. Disponível em: $<$ http://cpd1.ufmt.br/eest/index2.php?option $=$ com_docman\&task $=$ doc_view\&gid $=11$ 2\&Itemid $=99>$

SILVA, Luiz de Pinho Pedreira da. A reparação do dano moral no direito do trabalho. São Paulo: LTr, 2004.

SILVA, Maria Aparecida de Morais et al. Do karoshi no Japão à birôla no Brasil: as faces do trabalho no capitalismo mundializado. Revista Nera, ano 9, n. 8, jan.-jun. 2006. Disponível em: <http://www2.fct.unesp.br/nera/revistas/08/Silva.PDF>.

SILVA, Otavio Pinto e. Subordinação, autonomia e parassubordinação nas relações de trabalho. São Paulo: LTr, 2004.

SILVEIRA, Edilene Aparecida Araújo da; ROBAZZI, Maria Lúcia do Carmo Cruz; LUÍS, Margarita Antonia Villar. Varredores de rua: acidentes de trabalho ocorridos na cidade de Ribeirão Preto, Estado de São Paulo, Brasil. Revista Latino-americana de Enfermagem, Ribeirão Preto, v. 6, n. 1, jan. 1998.

SIMÕES, Carlos Jorge Martins. Direito do trabalho e modo de produção capitalista. São Paulo: Símbolo, 1979.

SOARES, Lirian Sousa. Decreto $n .{ }^{\circ}$ 6.042/2007 muda regras do SAT para as empresas. IOB: repertório de jurisprudência: tributário, constitucional e administrativo. São Paulo. v. 1. n. 8, abr. 2007.

SOUTO MAIOR, Jorge Luiz. Curso de direito do trabalho: teoria geral do direito do trabalho. São Paulo: LTr, 2011. v. 1, Parte I. 
SOUZA, Yeda Swirski de. Organizações de aprendizagem ou aprendizagem organizacional. Disponível em: <http://www.scielo.br/pdf/raeel/v3n1/v3n1a08>.

STUCHI, Victor Hugo Nazário. O trabalho penoso e a dignidade da pessoa humana. In: PIOVESAN, Flávia; CARVALHO, Luciana Paula Vaz de (Coord.). Direitos humanos e direito do trabalho. São Paulo: Atlas, 2010.

SÜSSEKIND, Arnaldo. Convenções da OIT. 2. ed. ampl. e atual. até ago. 1998. São Paulo: LTr, 1998.

—. Instituições de direito do trabalho. São Paulo: LTr, 2000. v. 2.

THIRY-CHERQUES, Hermano Roberto. Max Weber: o processo de racionalização e o desencantamento do trabalho nas organizações contemporâneas. Revista de Administração Pública, Rio de Janeiro: FGV, jul.-ago. 2009.

THOMPSON, E. P. Tempo, disciplina do trabalho e o capitalismo industrial. Costumes em comum. São Paulo: Companhia das Letras, 1998.

VALLE, Márcio Ribeiro do. In: BARROS, Alice Monteiro de. Curso de direito do trabalho: estudos em memória de Célio Goyatá. São Paulo: LTr, 1993. v. 2.

VELLOSO, Marta Pimenta; SANTOS, Elizabeth Moreira dos; ANJOS, Luiz Antonio dos. Processo de trabalho e acidentes de trabalho em coletores de lixo domiciliar na cidade do Rio de Janeiro, Brasil. Disponível em: $<$ http://www.scielosp.org/scielo.php?pid=S0102311X1997000400012\&script=sci_arttext $>$.

VIANNA, Segadas. In: SÜSSEKIND, Arnaldo. TEIXEIRA FILHO, João de Lima; MARANHÃO, Délio; TEIXEIRA, Lima. Instituições de direito do trabalho. São Paulo: LTr, 2000.

VILELA, L. V. O.; Assunção, A. A. Os mecanismos de controle da atividade no setor de teleatendimento e as queixas de cansaço e esgotamento dos trabalhadores. Cadernos de Saúde Pública, São Paulo, v. 20, n. 4, 2004. 
VILELA, Rodolfo Andrade G.; GIL VICENTE FONSECA, Ricardi; IGUTI, Aparecida Mari. Experiência do Programa de Saúde do Trabalhador de Piracicaba: desafios da vigilância em acidentes do trabalho. Inf. Epidemiol, Sus, Brasília, v. 10, n. 2, jun. 2001. Disponível em: $<$ http://scielo.iec.pa.gov.br/scielo.php?script=sci_arttext\&pid=S01041673200100020 $0003 \& \operatorname{lng}=\mathrm{es} \& \mathrm{nr}=\mathrm{iso}>$.

WEBER, Max. A ética protestante e o espírito do capitalismo. São Paulo: Martin Claret, 2012.

WEINTRAUB, Arthur Bragança de Vasconcellos. Direito sanitário previdenciário $e$ trabalhista. São Paulo: Quartier Latin, 2006.

WISNER, Alain. A inteligência no trabalho: textos selecionados de ergonomia. São Paulo: Fundacentro, 1994.

—. Por dentro do trabalho: ergonomia: método \& técnica. São Paulo: FTD: Oboré, 1987.

ZOLA, Émile. Germinal. São Paulo: Companhia das Letras, 2000.

Sítios consultados

http://agricultura.gov.br/vegetal/culturas/cana-de-acucar

http://www.apa.org/monitor/2011/01/night-work.aspx.

http://www.assis.unesp.br/encontrosdepsicologia/ANAIS_DO_XIX_ENCONTRO/46_Lau ro_Cesar_Ibanhes.pdf.

http://www.aulete.uol.com.br

http://www.boell-latinoamerica.org/downloads/resumo_-_dh_e_industria_da_canal.pdf http://www.camara.gov.br 
http://www.ciencia.hsw.uol.com.br/ferro-e-o-aco3.htm.

http://www.cpihts.com/PDF/Enc\%C3\%ADclica\%20Rerum\%20Novarum.pdf.

http://www010.dataprev.gov.br/sislex/paginas/05/mtb/1.htm

http://www.dielle.it/index.php?url=/consultazione/giurisprudenza_2/riposo_settimanale_59 7/in_genere_598/view/598/

http://www.economia.estadao.com.br/noticias/economia\%20brasil,cresce-acidente-detrabalho-com-volta-das-obras-, 100136,0.htm.

http://www.europa.eu/legislation_summaries/employment_and_social_policy/health_hygie ne_safety_at_work/c11113_pt.htm

http://www.eulex.europa.eu/LexUriServ/LexUriServ.do?uri=CELEX:31989L0391:pt:html

http://www.fiocruz.br/biosseguranca/Bis/lab_virtual/tipos_de_riscos.html.

http://www.fontedodireito.com.br/trabalhista/construtora-e-condenada-a-a-pagar-adicionalde-penosidade-a-servente-de-pedreiro.

http://www.fundacentro.gov.br

http://www.g1.globo.com/platb/globo-news-cidades-e-solucoes

http://www.ilo.org

http://www.jus.com.br/revista/texto/14779/adicional-de-penosidade\#ixzz2D5X1Ox2j

http://www.medtrab.ufpr.br/arquivosparadownload/PoliticaspublicaemSaudeeTrabalho/7vi gilancisrisco.pdf

http://www.moodle.fmb.unesp.br

http://www.mpas.gov.br 
http://www.observatoriosocial.org.br

http://www.oitbrasil.org.br

http://www.oitchile.cl/pdf/publicaciones/igu/igu021.pdf

http://oglobo.globo.com/saude/jetlag-social-um-novo-nome-para-estresse5477489\#ixzz2BwBAhN83

http://www.pardaladvocacia.com.br/site/html/content/artigos

http://www.planalto.gov.br

http://www.portal.mpt.gov.br/wps/portal_do_mpt/sobre_o_mpt/programas_nacionais

http://www.portal.mte.gov.br/data/files/FF8080812BA5F4B7012BAAEF2B746775/Prod1 4_2007.pdf.

http://www.previdencia.gov.br/conteudoDinamico.php?id=1209

http://www.professor.ucg.br/siteDocente/admin/.../Teoria\%20de\%20Maslow.doc.

http://www.psiqweb.med.br

http://www.redebrasilatual.com.br

http://www.saude.gov.br

http://www.scielo.br/pdf/physis/v17n1/v17n1a03.pdf

http://www.scielo.br/pdf/rac/v5n2/v5n2a09.pdf

http://www.seade.gov.br

http://www.senado.gov.br 
http://www.sinait.org.br

http://www.sindjuf-paap.org.br

http://www.stj.jus.br

http://www.stf.jus.br

http://www.trtsp.jus.br

http://www.tst.jus.br

http://www.unica.com.br

http://www.urbanitariosdf.org.br

http://www.veja.abril.com.br 


\section{RESUMO}

O presente estudo enfoca o trabalho penoso e as consequências nocivas à saúde dos trabalhadores que exercem atividades penosas, com evidência na reparação social dos danos e com fundamento nos princípios ambientais.

Analisam-se o trabalho na sociedade atual, o processo de organização do trabalho, a globalização da economia, a precarização das relações de trabalho e os impactos sobre a saúde dos trabalhadores.

Os princípios ambientais são estudados, bem como todo o arcabouço constitucional e legal de proteção ao direito à saúde no trabalho. Efetua-se o debate acerca do papel da sociedade civil, das entidades sindicais, dos empregadores, bem como dos poderes públicos, na fiscalização do meio ambiente de trabalho e na prevenção de doenças e acidentes do trabalho. A responsabilidade do empregador é examinada à luz da doutrina e da jurisprudência predominante nos nossos Tribunais.

Realiza-se o estudo de doutrina sobre medicina do trabalho, em especial de ergonomia, psicologia do trabalho, bem como de textos de filosofia e sociologia do trabalho, economia e administração de empresas, para a caracterização da penosidade.

Por fim, são debatidas formas de reparação dos danos, descartando-se a via da monetização do risco. Propõe-se a revogação de legislação em vigor, para que nova normatização efetivamente imponha aos responsáveis pelos danos causados aos trabalhadores, os empregadores que exigem tarefas ou condições de trabalho no limite do risco proibido, o dever de arcar com as despesas da reparação, de ressarcimento dos benefícios que serão gastos pelos cofres públicos.

Palavras-chave: Trabalho penoso; saúde do trabalhador; princípios ambientais; princípio do poluidor-pagador; reparação social de danos. 


\begin{abstract}
This study approaches the unsafe or overly strenuous labor practises and its nocuous effects on workers' health, especially the compensation of the social harms based on the environmental principles.

An analysis of the work in the current society is undertaken, along with that of the work organization process, of the economic globalization, of the deterioration of the working conditions and the impacts on the workers' health.

The environmental principles are addressed, as well as the entire occupational health protection legal framework, along with the debate regarding the roles of society, trade unions, employers, as well as the role of the government on investigating the work environment and preventing labor accidents and diseases. The employers' responsibility is examined, according to the prevailing doctrine and cases.

There are the doctrine studies regarding occupational medicine, especially ergonomics, occupational psychology; including the study of texts relating to labor philosophy and sociology, economy and business management, in order to distinguish the laboriousness.

Lastly, there is the discussion about the compensation of the damages, excluding the commodification of the risk. The proposition repeals the current act, in order for the new statute to effectively hold the employers accountable for the damages caused to the employees, through the burden of bearing the costs of the reparation, as well as the reimbursement of the expenses incurred by the Treasury.
\end{abstract}

Keywords: unsafe or overly strenuous labor practises; workers' health; environmental principles; "polluter pays" principle; compensation of the social harms. 


\section{RIASSUNTO}

Questa ricerca presenta il lavoro penoso e le sue conseguenze nocive alla salute dei lavoratori che svolgono attività penose, dà attenzione alla riparazione sociale dei danni fondati nei principi ambientali.

È analizzato il lavoro nella società attuale, il processo di organizzazione del lavoro, la globalizzazione dell'economia, la precarizzazione dei rapporti di lavoro e gli impatti sulla salute dei lavoratori.

Sono studiati i principi ambientali e le regole costituzionali e legali di protezione al diritto sanitario nel lavoro. Si fa un dibattito intorno al ruolo della società civile, delle entità sindacali, dei datori di lavoro e dei poteri pubblici nella fiscalizzazione dell'ambiente di lavoro e nella prevenzione di malattie e infortuni sul lavoro. La responsabilità del datore di lavoro è esaminata alla luce della dottrina e giurisprudenza predominante nei nostri Tribunali.

Per caratterizzare la penosità si fa lo studio di dottrina sulla medicina del lavoro, in speciale di ergonomia, psicologia del lavoro, testi di filosofia e sociologia del lavoro, economia e amministrazione aziendale.

Infine, sono dibattute le forme di riparazioni dei danni, escludendosi la via della monetizzazione del rischio. Si propone la revoca della legislazione in vigore affinché una nuova normalizzazione imponga effettivamente ai responsabili per $\mathrm{i}$ danni causati ai lavoratori, cioè, ai datori di lavoro che non rispettano il limite di rischio del lavoratore, il dovere di pagare le spese di riparazione, di risarcimento dei benefici spesi dalle casse dello stato.

Parole-chiave: lavoro penoso; salute del lavoratore; principi ambientali; principio inquinatore-pagatore; riparazione sociale dei danni. 